\title{
COMPLICITY IN INTERNATIONAL LAW
}

Miles Jackson

University College, University of Oxford 


\section{ABSTRACT}

\section{Complicity in International Law}

This thesis is concerned with the ways in which international law regulates state and individual complicity. Complicity is a derivative form of responsibility that links an accomplice to wrongdoing by a principal actor. Whenever complicity is prohibited, certain questions arise about the scope and structure of the complicity rule. To answer these questions, this thesis proposes an analytical framework in which complicity rules may be assessed, and defends a normative claim as to their optimal structure. This framework and normative claim anchor the thesis' analysis of complicity in international law. The thesis shows that international criminal law regulates individual complicity in a comprehensive way, using the doctrines of instigation and aiding and abetting to inculpate complicit participants in international crimes. These doctrines are marked by the breadth of the complicit conduct prohibited, a standard of knowledge in the fault required of the accomplice, and an underused nexus requirement between the accomplice's acts and the principal's wrong. In contrast, international law's regulation of state complicity was historically marked by an absence of complicity rules. In respect of state complicity in the wrongdoing of another state, international law now imposes both specific and general complicity obligations, the latter prohibiting states from aiding or assisting another state in the commission of any internationally wrongful act. In respect of the ways that states participate in harms caused by non-state actors, the traditional normative structure of international law, which imposed obligations only on states, foreclosed the possibility of regulating the state's participation as a form of complicity. As that traditional normative structure has evolved, so the possibility of holding states responsible for complicity in the wrongdoing of non-state actors has emerged. More and more, both the wrongs that international actors commit, and the wrongs they help or encourage others to commit, matter. 


\section{ACKNOWLEDGEMENTS}

Complicity is a subject that lends itself to an appreciation of support and encouragement. First and foremost, I would like to thank Mr Dapo Akande, my supervisor, for his direction and advice on the thesis, both of which were indispensable, and for his warm support and friendship beyond it. I owe him a debt of gratitude.

I owe an intellectual debt to those who taught me international law, in particular Professor Stefan Talmon, for his rigour and inspiration many years ago, and Professors Ryan Goodman and William Alford. In addition, I am immensely grateful, both personally and professionally, to Dr Liora Lazarus.

I am also thankful to all at the University of Oxford and elsewhere who discussed drafts, chapters, and ideas with me: Professor Andrew Ashworth, Sir Frank Berman, Professor Michael Bohlander, Professor John Gardner, Professor Guy Goodwin-Gill, Dr Imogen Goold, Professor Doug Husak, Professor Nina Jørgensen, Dr Maris Köpcke Tinturé, Professor Vaughan Lowe, Professor André Nollkaemper, Dr Antonios Tzanakopoulos, and Professor Stefan Vogenauer.

I would like to thank Farid Ahmadov, Nick Friedman, Ryan Goss, Thomas Liefländer, Kubo Mačák, Travers McLeod, Rob Mullins, and Nikki Palmer for their help and advice along the way. I am also immensely grateful to Anna Begemann, Caitlin Goss, and Natasha Simonsen, all of whom read the entire draft and for whose comments it is vastly better.

This project would not have commenced without the generosity of the Rhodes Trust. I am grateful to all at Rhodes House, especially Mary Eaton, John Gee, Don Markwell, Colin Page, and Bob Wyllie. I am also indebted to the staff of the Law Faculty at the University of Oxford, the University's many libraries and librarians, and to University College, Oxford.

Finally, I am deeply grateful to my family for their love and support, and to Emily Uecker for those and much more. 
TABLE OF CONTENTS

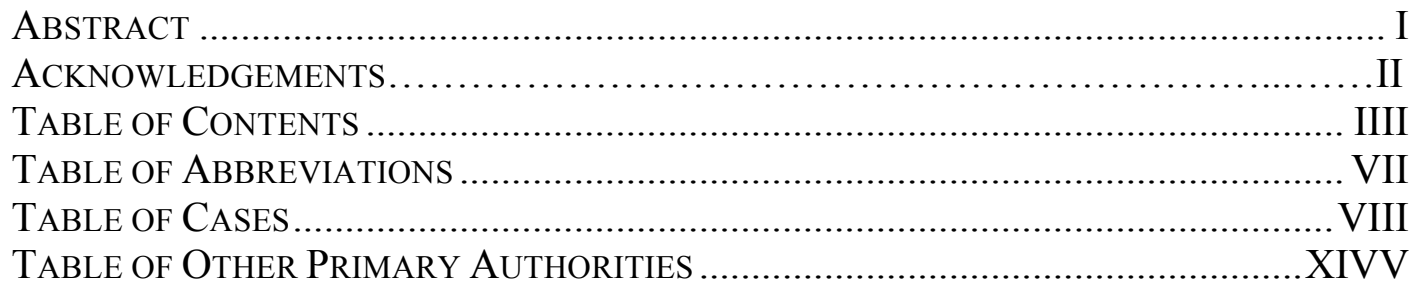

\section{Part A. A Theory Of Complicity}

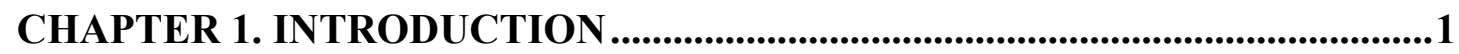

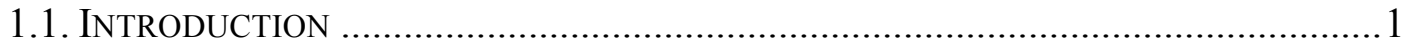

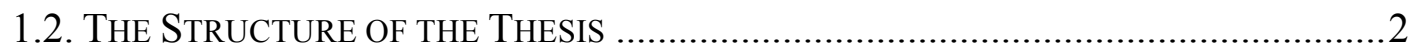

1.3. THE SCOPE OF THE THESIS .............................................................................6

CHAPTER 2. THE STRUCTURE OF COMPLICITY .......................................10

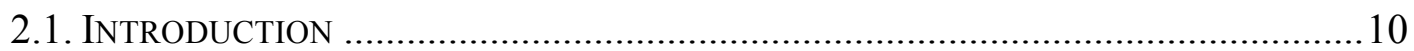

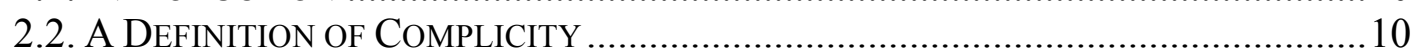

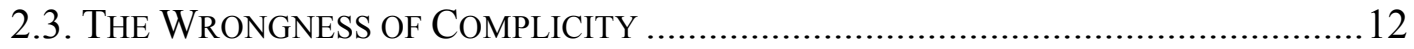

2.3.1. Moral and Legal Wrongs .................................................................... 12

2.3.2. An Analogy to Inducing Breach of Contract ............................................ 15

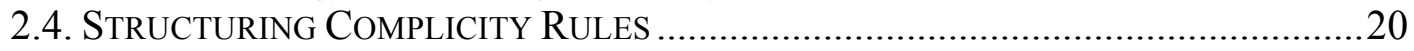

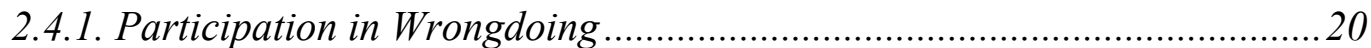

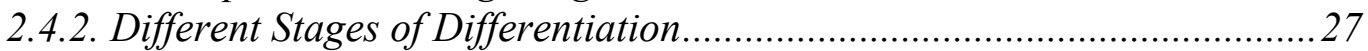

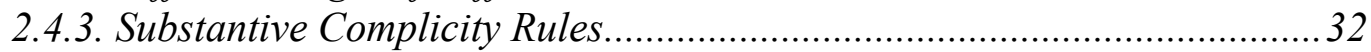

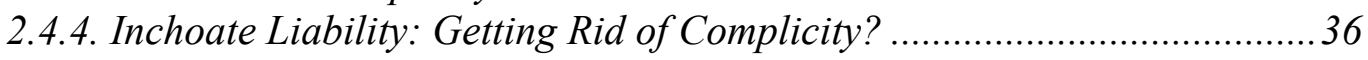

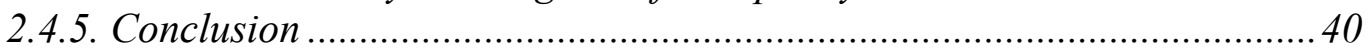

2.5. ProhiBITING COMPLICITY: AN ANALYTICAL FRAMEWORK.................................40

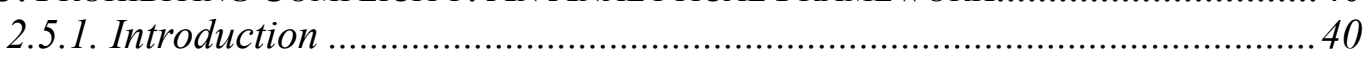

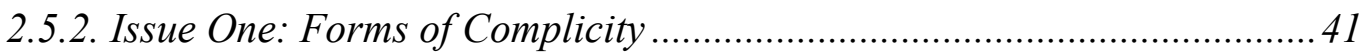

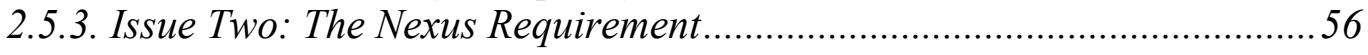

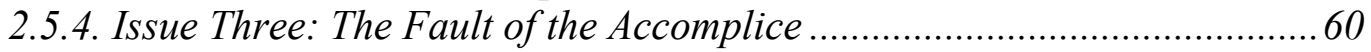

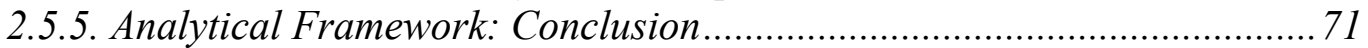

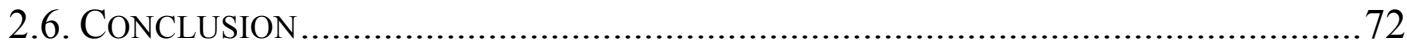

Part B. Complicity in International Criminal LaW

CHAPTER 3. INDIVIDUAL CRIMINAL RESPONSIBILITY .............................74

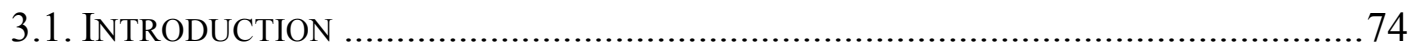

3.2. The SCOPE OF PART B OF THE THESIS ……................................................... 75

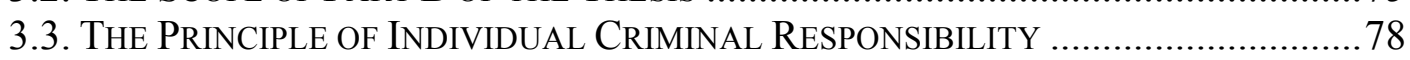

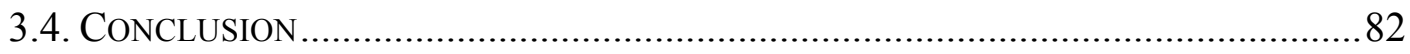

CHAPTER 4. PARADIGM DOCTRINES OF COMPLICITY IN

INTERNATIONAL CRIMINAL LAW....................................................................83

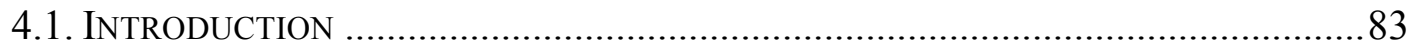

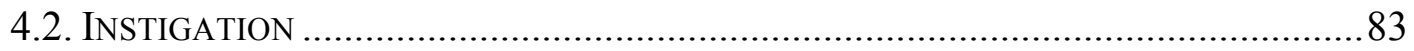

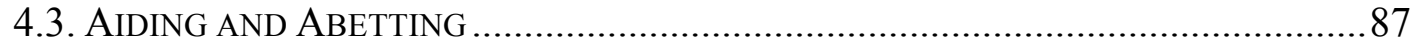

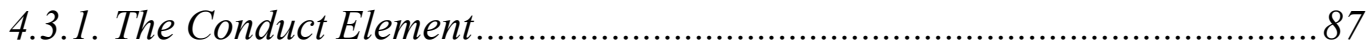

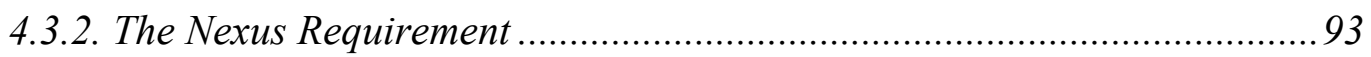




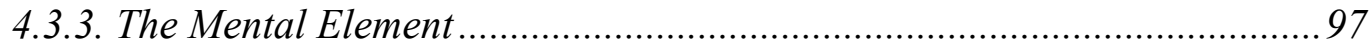

4.4. The STRUCTURE OF COMPLICITY IN INTERNATIONAL CRIMINAL LAW .............104

4.4.1. Differentiation in the Attribution of Responsibility ................................104

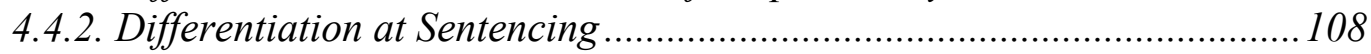

4.5. LOCATING THE RULES WITHIN THE ANALYTICAL FRAMEWORK.......................110

4.6. COMPLICITY IN GENOCIDE - A CODA FOR NON-IMPUTATIONAL COMPLICITY .112

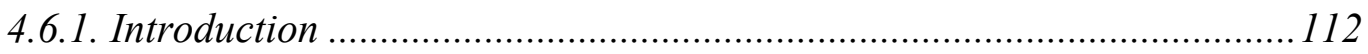

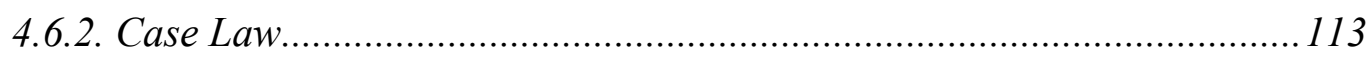

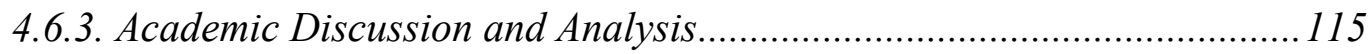

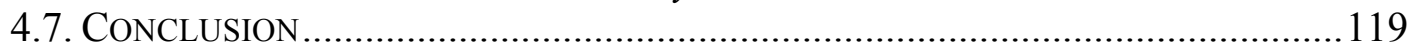

CHAPTER 5. CULPABLE OMISSIONS AND COMPLICITY IN

INTERNATIONAL CRIMINAL LAW...........................................................120

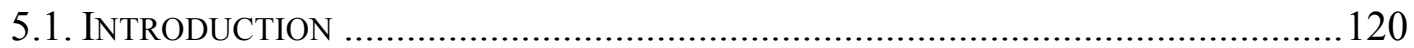

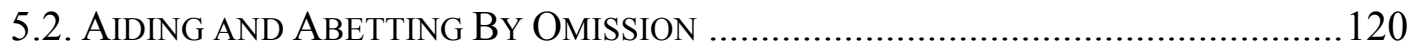

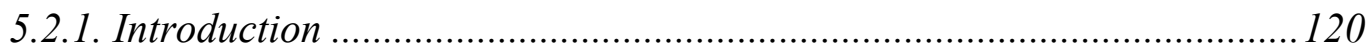

5.2.2. The ICTY Trial Chamber in Mrkšić..................................................... 122

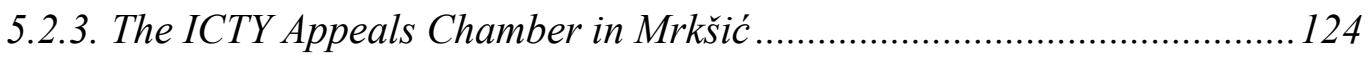

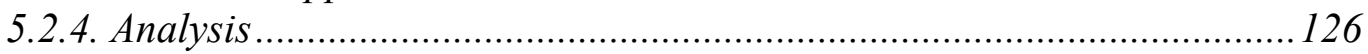

5.2.5. Omissions and the Other Elements of Aiding and Abetting Liability...... 134

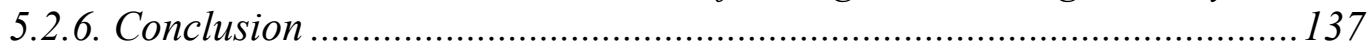

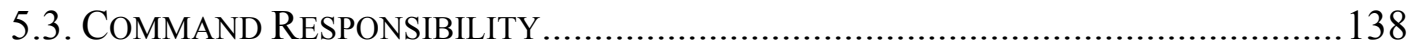

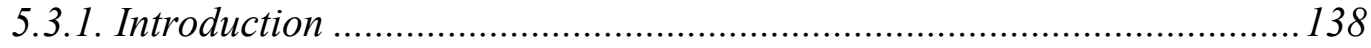

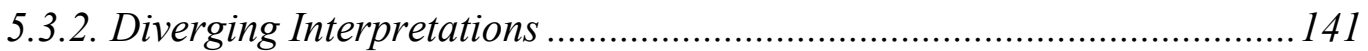

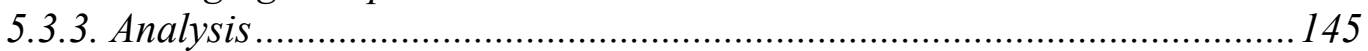

5.3.4. Command Responsibility and Complicity: Conclusion ..........................151

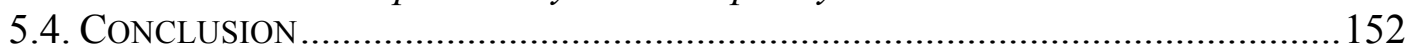

\section{Part C. State Complicity in InTERnational LaW}

CHAPTER 6. STATE COMPLICITY - A FRAMEWORK................................154

6.1. State Complicity IN State Wrongdoing.................................................154

6.2. State Participation In the ACts OF Non-State ACTORS - A CONCEPTUAL

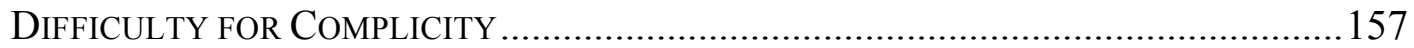

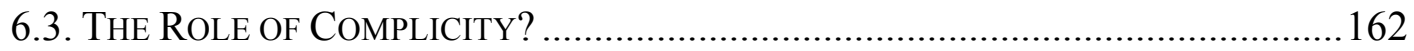

6.4. The StRUCTURE OF PART C OF THE THESIS .................................................. 164

CHAPTER 7. STATE COMPLICITY IN THE INTERNATIONALLY WRONGFUL ACT OF ANOTHER STATE ....................................................167

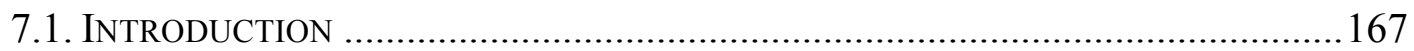

7.2. State Complicity in Aggression - A SPECIFIC CoMplicity Rule .............168

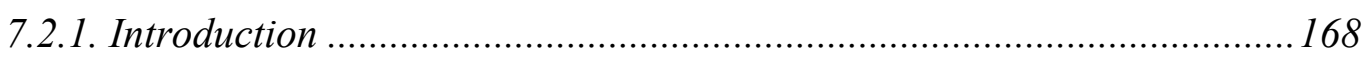

7.2.2. Placing Territory at the Disposal of an Aggressor State....................... 169

7.2.3. Beyond Territorial Complicity ............................................................. 180

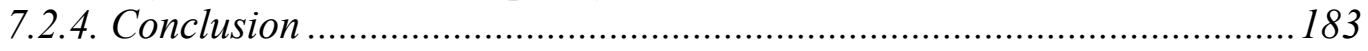

7.3. A GENERAL COMPLICITY RULE - ARTICLE 16 ARSIWA .................................184

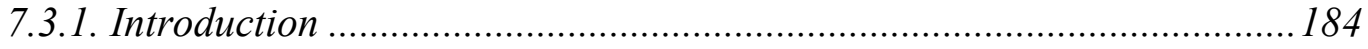

7.3.2. The Basic Structure of the Articles on State Responsibility.....................185

7.3.3. The Primary Nature of Article 16 ............................................................ 186

7.3.4. The Legal Status of Article 16.............................................................. 189

7.3.5. Assessing the Rule with the Analytical Framework ............................... 192 
7.3.6. The Double Obligation Requirement .................................................204

7.3.7. Evaluating the Structure of the Rule in Article 16................................2212

7.3.8. Complicity and the Monetary Gold Principle ........................................2217

7.3.9. Article 16, the Prohibition on Complicity in Aggression, and Peremptory

Norms of International Law........................................................................219

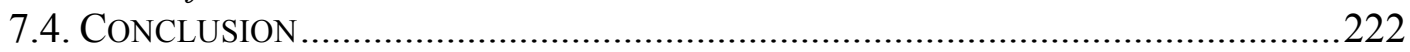

CHAPTER 8. STATE COMPLICITY, NON-STATE ACTORS, AND

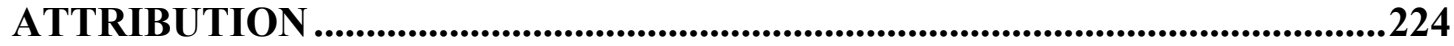

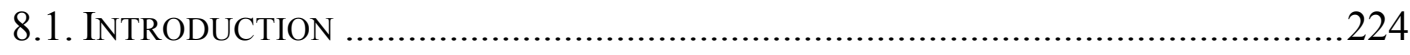

8.2. ATTRIBUTION IN INTERNATIONAL LAW - BASELINES ..................................225

8.3. State Participation In TERrorist AtTACKS AND the Rules of

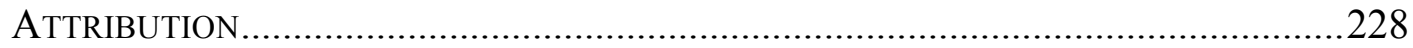

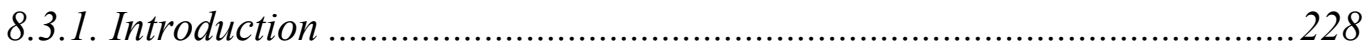

8.3.2. The Approach of the ICJ........................................................................222

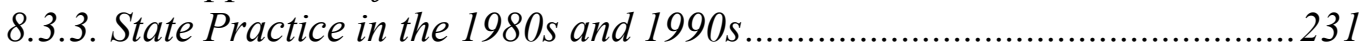

8.3.4. A New Era of Terrorism........................................................................2234

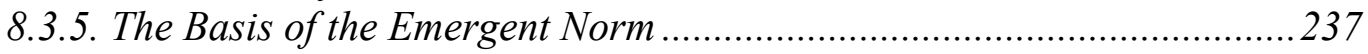

8.3.6. The Residual Role of Complicity ...............................................................241

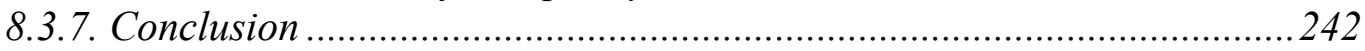

8.4. State Participation in Human Rights Violations AND the RULES OF

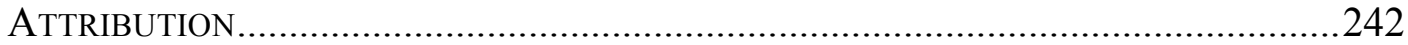

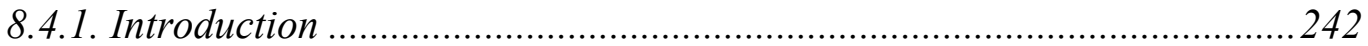

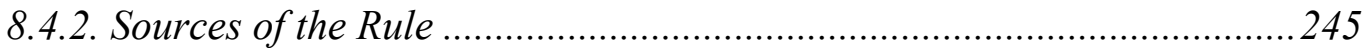

8.4.3. Understanding the Attributional Approach ............................................249

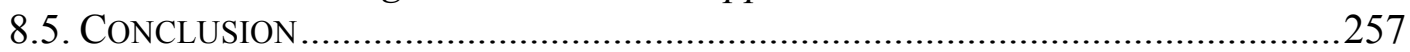

\section{CHAPTER 9. STATE COMPLICITY AND THE OBLIGATIONS OF NON-}

STATE ACTORS..........................................................................................259

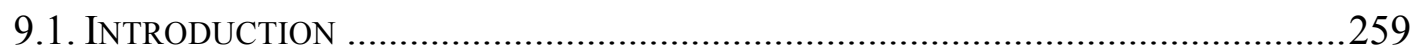

9.2. State Complicity IN GenOCIDE - A SPECIFIC RUle .....................................260

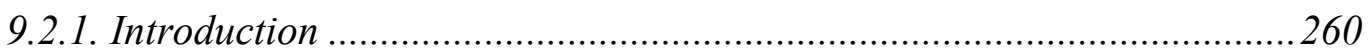

9.2.2. The Reasoning of the ICJ..................................................................261

9.2.3. Criticism of the Court's Approach...........................................................2263

9.2.4. The Content of the Rule - The Court's Approach .................................267

9.2.5. Assessing the Rule within the Analytical Framework of the Thesis ........270

9.2.6. Evaluating the Structure of the Rule .......................................................2.279

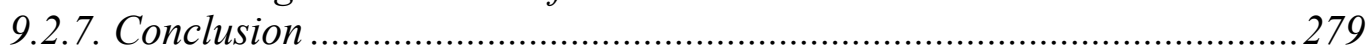

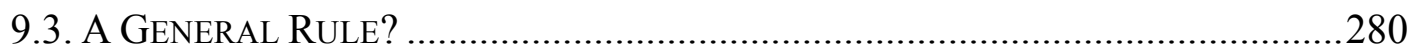

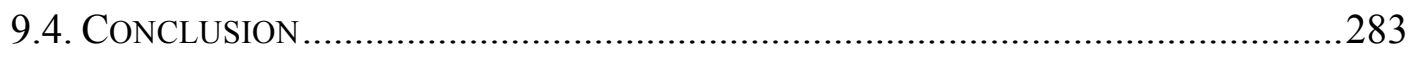

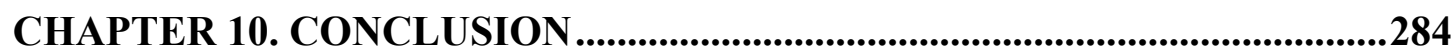

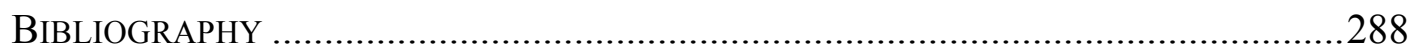




\section{TABLE OF ABBREVIATIONS}

\begin{tabular}{|c|c|}
\hline ARSIWA & Articles on Responsibility of States for Internationally Wrongful Acts \\
\hline CIA & Central Intelligence Agency \\
\hline DRC & Democratic Republic of the Congo \\
\hline ECHR & European Convention on Human Rights \\
\hline EHRR & European Human Rights Reports \\
\hline FARC & Revolutionary Armed Forces of Colombia \\
\hline FRG & Federal Republic of Germany \\
\hline FRY & Federal Republic of Yugoslavia \\
\hline GCIII & $\begin{array}{l}\text { Convention (III) Relative to the Treatment of Prisoners of War (adopted } 12 \text { August } \\
1949 \text {, entered into force } 21 \text { October 1950) } 75 \text { UNTS } 135\end{array}$ \\
\hline ICC & International Criminal Court \\
\hline ICCPR & International Covenant on Civil and Political Rights \\
\hline ICJ & International Court of Justice \\
\hline ICTR & International Criminal Tribunal for Rwanda \\
\hline ICTY & International Criminal Tribunal for the former Yugoslavia \\
\hline ILC & International Law Commission \\
\hline IMT & International Military Tribunal \\
\hline JCE & Joint Criminal Enterprise \\
\hline JNA & Yugoslav People's Army \\
\hline LQR & Law Quarterly Review \\
\hline LRTWC & Law Reports of Trials of War Criminals \\
\hline NATO & North Atlantic Treaty Organization \\
\hline OAS & Organization of American States \\
\hline PCIJ & Permanent Court of International Justice \\
\hline PKK & Kurdistan Workers' Party \\
\hline RIAA & Reports of International Arbitral Awards \\
\hline SCSL & Special Court for Sierra Leone \\
\hline StGB & Strafgesetzbuch \\
\hline TO & Territorial Defense Forces, Yugoslavia \\
\hline UAE & United Arab Emirates \\
\hline UK & United Kingdom \\
\hline UN & United Nations \\
\hline UNGA & United Nations General Assembly \\
\hline UNHRC & United Nations Human Rights Committee \\
\hline UNSC & United Nations Security Council \\
\hline UNTS & United Nations Treaty Series \\
\hline US & United States of America \\
\hline USC & United States Code \\
\hline USSR & Union of Soviet Socialist Republics \\
\hline VCLT & Vienna Convention on the Law of Treaties \\
\hline VRS & Army of the Republika Srpska \\
\hline YILC & Yearbook of the International Law Commission \\
\hline
\end{tabular}




\section{TABLE OF CASES}

\section{$\underline{\text { International Courts and Tribunals }}$}

\section{International Court of Justice}

Application of the Convention on the Prevention and Punishment of the Crime of Genocide (Bosnia and Herzegovina $v$ Serbia and Montenegro) (Merits) [2007] ICJ Rep 43
$5,55,161,162,190$ $194,196,220,226-$

$228,240,261,263-$

$265,267,269,271$,

275,277

Armed Activities on the Territory of the Congo (Democratic Republic of Congo v Uganda) (Merits) [2005] ICJ Rep 168

$169,183,227$ $230-231,241,273$

Case of the Monetary Gold Removed from Rome in 1943 (Italy v France, United Kingdom and United States of America) (Preliminary Question) [1954] ICJ Rep 19

Corfu Channel (United Kingdom v Albania) (Merits) [1949] ICJ Rep 4

East Timor (Portugal v Australia) [1995] ICJ Rep 90

Legal Consequences for States of the Continued Presence of South Africa in

Namibia (South West Africa) notwithstanding Security Council Resolution

276 (1970) (Advisory Opinion) [1971] ICJ Rep 16

Legal Consequences of the Construction of a Wall in the Occupied

Palestinian Territory (Advisory Opinion) [2004] ICJ Rep 136

Legality of the Threat or Use of Nuclear Weapons (Advisory Opinion) [1996]

ICJ Rep 226

Military and Paramilitary Activities in and against Nicaragua (Nicaragua $v$ United States) (Merits) [1986] ICJ Rep 14

United States Diplomatic and Consular Staff in Tehran (United States of 161 America v Iran) (Merits) [1980] ICJ Rep 3

\section{Permanent Court of International Justice}

\section{International Criminal Court}

Prosecutor v Bemba Gombo (Decision on the Confirmation of Charges) ICC01/05-01/08 (15 June 2009) 
Prosecutor v Lubanga Dyilo (Decision on the Confirmation of Charges) ICC01/04-01/06 (29 January 2007)

Prosecutor v Lubanga Dyilo (Trial Chamber Judgment) ICC-01/04-01/06 (14

March 2012)

Prosecutor v Mbarushimana (Decision on the Confirmation of Charges) ICC-

\section{International Criminal Tribunal for Rwanda}

Prosecutor v Akayesu (Trial Chamber Judgment) ICTR-96-4-T (2 September $92,104,113,115$ 1998)

Prosecutor v Akayesu (Appeals Chamber Judgment) ICTR-96-4 (1 June

Prosecutor v Karemera, Ngirumpatse, Nzirorera (Trial Chamber Decision on

ICTR-99-52-A (28 November 2007)

Prosecutor v Ntagerura, Bagambiki, Imanishimwe (Trial Chamber Judgment)

ICTR-99-46-T ((25 February 2004)

Prosecutor v Ntakirutimana, Ntakirutimana (Appeals Chamber Judgment)

ICTR-96-10-A \& ICTR-96-17-A (13 December 2004)

Prosecutor v Rutaganira (Trial Chamber Judgment) ICTR-95-1C-T (14

March 2005)

Prosecutor v Semanza (Trial Chamber Judgment) ICTR-97-20-T (15 May 2003)

\section{International Criminal Tribunal for the Former Yugoslavia}

Prosecutor v Aleksovski (Trial Chamber Judgment) IT-95-14/1-T (25 June 1999)

Prosecutor v Blagojević, Jokić (Trial Chamber Judgment) IT-02-60-T (17 January 2005) 
Prosecutor v Blaškić (Appeals Chamber Judgment) IT-95-14-A (29 July 2004) Interlocutory Appeal Challenging Jurisdiction in Relation to Command Responsibility) IT-01-47-AR72 (16 July 2003)

Prosecutor v Halilović (Trial Chamber Judgment) IT-01-48-T (16 November 2005)

Prosecutor v Haradinaj, Balaj, Brahimaj (Appeals Chamber Judgment) IT04-84-A (19 July 2010)

Prosecutor v Kunarac, Kovač, Vuković (Trial Chamber Judgment) IT-96-23T \& IT-96-23/1-T (22 February 2001) 
Prosecutor v Mucić et al (Čelebići) (Appeals Chamber Judgment) IT-96-21-A $95,109,139,142$ (20 February 2001)

Prosecutor v Orić (Trial Chamber Judgment) IT-03-68-T (30 June 2006) $86,128,141-142$, 146,151

Prosecutor v Orić (Appeals Chamber Judgment) IT-03-68-A (3 July 2008) $66,68,86,97-98,142$

Prosecutor v Perišić (Trial Chamber Judgment) IT-04-81-T (6 September 134 2011)

Prosecutor v Perišić (Appeals Chamber Judgment) IT-04-81-A (28 February 2013)

$66,89-90,101-102$

Prosecutor v Simić (Appeals Chamber Judgment) IT-95-9-A (28 November 2006)

$68-69,93,95,98,277$

Prosecutor v Šljivančanin (Appeals Chamber Review Judgment) IT-95-13/1-

R.1 (8 December 2010)

Prosecutor v Stakić (Trial Chamber Judgment) IT-97-24-T (31 July 2003)

Prosecutor v Strugar (Trial Chamber Judgment) IT-01-42-T (31 January $12,95-96$ 2005)

Prosecutor v Tadić (Trial Chamber Judgment) IT-94-1-T (7 May 1997)

Prosecutor v Tadić (Appeals Chamber Judgment) IT-94-1A (15 July 1999)

\section{Special Court for Sierra Leone}

Prosecutor v Taylor (Appeals Chamber Judgment) SCSL-03-01-A (26 $66,88,90,93,100$ September 2013) $102,106,110,217$

\section{Post-Second World War Trials}

Judgment of the Nuremberg International Military Tribunal (1 October 1946) 


\section{European Court of Human Rights}

Chahal v United Kingdom (App 22414/93) (1996) 23 EHRR 413

El-Masriv The Former Yugoslav Republic of Macedonia (App 39630/09) (13

December 2012)

Ilașcu and Others v Moldova and Russia (App 48787/99) (2005) 40 EHRR

1030 .

Ireland v United Kingdom (App 5310/71) (1978) 2 EHRR 25

Kiliç v Turkey (App 22492/93) (2000) 33 EHRR 1357

Mamatkulov and Askarov v Turkey (Apps 46827/99 \& 46951/99) (2005) 41 EHRR 25

Soering v United Kingdom (App 14038/88) (1989) 11 EHRR 439

$7,248,255-256$

\section{Inter-American Commission on Human Rights}

Riofrio Massacre (Colombia) (6 April 2001) Inter-Am. C. H.R., Report No. $62 / 01$

\section{Inter-American Court of Human Rights}

Mapiripán Massacre (Colombia) (15 September 2005) Inter-Am. Ct. H.R.,

\section{Arbitral Tribunals}

Island of Palmas (Netherlands/USA) (1928) 2 RIAA 829

$161,163,177,242$

Spanish Zone of Morocco Case (United Kingdom/Spain) (1923) 2 RIAA 615

\section{United Nations Human Rights Committee}




\section{$\underline{\text { Domestic Courts }}$}

\section{England and Wales}

\begin{tabular}{|c|c|}
\hline Cassady v Reg Morris (Transport) Ltd [1975] RTR 470 (DC) & 48 \\
\hline Crampton v Fish [1969] 113 S.J. 1003 (DC) & 48 \\
\hline DPP for Northern Ireland v Lynch [1975] AC 653 (HL) & 63 \\
\hline Du Cros v Lambourne [1907] 1 KB 40 (KB) & 48 \\
\hline $\begin{array}{l}\text { Gillick } v \text { West Norfolk and Wisbech Area Health Authority and the } \\
\text { Department of Health and Social Security [1986] AC } 112 \text { (HL) }\end{array}$ & $64-65$ \\
\hline Hyam v DPP [1975] AC 55 (HL) & 61 \\
\hline Johnson v Youden [1950] 1 KB 544 (DC) & $67-68$ \\
\hline Lumley v Gye [1853] 118 E.R. 749 (QB) & $16-19$ \\
\hline Maxwell v DPP for Northern Ireland [1979] 68 Cr. App. R. 128 (HL) & $67-68,99$ \\
\hline Morby (1882) 8 QBD 571 (QB) & 51 \\
\hline OBG Limited and Others $v$ Allan and Others [2008] 1 AC 1 (HL) & 18 \\
\hline$R v$ Bainbridge [1960] 1 QB 129 (CCA) & 68 \\
\hline$R v$ Clarkson (1971) 55 Cr. App. R. 445 (CMAC) & 92 \\
\hline$R v$ Coney (1882) 8 QBD 534 (DC) & 92 \\
\hline$R v$ Giannetto [1997] 1 Cr. App. R. 1 (CA) & 91 \\
\hline$R v$ Harris [1964] Crim. LR 54 (CA) & 48 \\
\hline$R v \operatorname{Instan}[1893] 1 \mathrm{QB} 450(\mathrm{QB})$ & 50 \\
\hline$R v$ Marlow [1998] 1 Cr. App. R. (S.) 273 (CA) & 37 \\
\hline$R v$ Miller $[1983] 2$ AC $161(\mathrm{HL})$ & $49,128,133$ \\
\hline$R v$ Pittwood [1902] 19 TLR 37 (A) & $49-50,53,128$ \\
\hline$R v$ Russell (1933) VLR 59 (Vt) & 54 \\
\hline$R v$ Webster [2006] EWCA Crim. 415 (CA) & 48 \\
\hline Rubie v Faulkner [1940] 1 KB 571 (KB) & 47 \\
\hline Tuck v Robson [1970] 1 All ER 1171 (QB) & 48 \\
\hline Wilcox v Jeffery [1951] 1 All ER 464 (DC) & 91 \\
\hline
\end{tabular}




\section{Germany}

\section{United States of America}

Backun v United States (1940) 112 F.2d 635 ( $4^{\text {th }}$ Cir.)

$\begin{array}{ll}\text { In re Yamashita } 327 \text { US } 1 \text { (1946) (USSC) } & 138\end{array}$

Pinkerton v United States 328 US 640 (1946) (USCC) 76

State v Fortner, 182 W. Va. 345, 387 S.E.2d 812 (1989) (West Virginia) 30

$\begin{array}{ll}\text { State v Tally (1894) } 15 \text { So } 722 \text { (Alabama) } & 94\end{array}$

United States $v$ Peoni (1938) 100 F.2d $401\left(2^{\text {nd }}\right.$ Cir. $)$

\section{The Netherlands}

Prosecutor v Frans van Anraat LJN: BG4822, 07/10742 (Dutch Supreme 


\section{TABLE OF Other Primary AUthorities}

\section{Multilateral Treaties}

Agreement for the Prosecution and Punishment of the Major War Criminals

of the European Axis (signed in London, 8 August 1945) 82 UNTS 279

American Convention on Human Rights (adopted 22 November 1969, entered

Charter of the United Nations (adopted 26 June 1945, entered into force 25

October 1945) 1 UNTS XVI

Convention against Torture and Other Cruel, Inhuman or Degrading

Treatment or Punishment (adopted 10 December 1984, entered into force 26

June 1987) 1465 UNTS 85

Convention concerning the Rights and Duties of Neutral Powers in Naval

War (adopted 18 October 1907, entered into force 26 January 1910) 36 Stat. 2415

Convention of 4 July 1831 between France and the United States of America

194,272 (ratified on 2 February 1832)

Convention on the Prevention and Punishment of the Crime of Genocide (adopted 9 December 1948, entered into force 12 January 1951) 78 UNTS 277

Convention (I) for the Amelioration of the Condition of the Wounded and Sick in Armed Forces in the Field (adopted 12 August 1949, entered into force 21 October 1950) 75 UNTS 31

Convention (II) for the Amelioration of the Condition of Wounded, Sick and Shipwrecked Members of Armed Forces at Sea (adopted 12 August 1949, entered into force 21 October 1950) 75 UNTS 85

Convention (III) Relative to the Treatment of Prisoners of War (adopted 12 August 1949, entered into force 21 October 1950) 75 UNTS 135

Convention (IV) Relative to the Protection of Civilian Persons in Time of War (adopted 12 August 1949, entered into force 21 October 1950) 75 UNTS 287

(European) Convention for the Protection of Human Rights and Fundamental Freedoms (adopted 4 November 1950, entered into force 3 September 1953; as amended) 213 UNTS 222

International Convention for the Suppression of Terrorist Bombings (adopted 15 December 1997, entered into force 23 May 2001) 2149 UNTS 284

International Covenant on Civil and Political Rights (adopted 16 December 1966, entered into force 23 March 1976) 999 UNTS 171

Protocol Additional to the Geneva Conventions of 12 August 1949, and
$46,112-113,117,190$, $194,261-262,264-$ $267,270-271$

$281-282$

$281-282$

$281-282$

$281-282$

$7,249,255$ (adopted 8 June 1977, entered into force 7 December 1978) 1125 UNTS 3 
Rome Statute of the International Criminal Court (adopted 17 July 1998, entered into force 1 July 2002) 2187 UNTS 90
$43,66,77,80,88$ $100,107,110,112$ $113,132,144,147$, $151,264,273,278$

Vienna Convention on the Law of Treaties (adopted 23 May 1969, entered into force 27 January 1980) 1155 UNTS 331

\section{Resolutions of the United Nations Security Council}

Resolution 418 (1977) of 4 November 1977

Resolution 822 (1993) of 30 April 1993

Resolution 827 (1993) of 25 May 1993

74,112

Resolution 853 (1993) of 29 July 1993

Resolution 874 (1993) of 14 October 1993

Resolution 884 (1993) of 12 November 1993

Resolution 955 (1994) of 8 November 1994

Resolution 1368 (2001) of 12 September 2001

Resolution 1373 (2001) of 28 September 2001

159,242

\section{Resolutions of the United Nations General Assembly}

Resolution 174 (II) (21 November 1947)

Resolution 498 (V) (1 February 1951)

Resolution 2625 (XXV) (24 October 1970)

Resolution 3314 (XXIX) (14 December 1974)

Resolution 36/27 (13 November 1981)

Resolution 37/123 (16 December 1982)

Resolution 40/61 (9 December 1985)

Resolution 41/38 (20 November 1986)

Resolution 44/29 (4 December 1989)

Resolution 49/60 (9 December 1994)

Resolution 51/210 (17 December 1996) 


\section{United Nations International Law Commission}

Special Rapporteurs

Ago R, 'Second Report on State Responsibility - the Origin of International

\section{Documents}

'Observations and Comments from Governments on Chapters I, II, and III of

Part I of the Draft Articles on State Responsibility for Internationally

Wrongful Acts' (1980) UN Doc A/CN.4/328

'State Responsibility - Comments and Observations Received from

Governments' (1998) UN Doc A/CN.4/488

'State Responsibility - Comments and Observations Received from

Governments' (1999) UN Doc A/CN.4/492

'State Responsibility - Comments and Observations Received From

Governments' (2001) UN Doc A/CN.4/515

'Responsibility of International Organizations - Texts and Titles of Draft

\section{United Nations Treaty Bodies}

UNHRC, 'General Comment 20' (10 March 1992) UN Doc HRI/GEN/1/Rev.1 30 (1994) 
UNHRC, 'Joint Study on Global Practices in relation to Secret Detention in the Context of Countering Terrorism' (19 February 2010) UN Doc.

A/HRC/13/42

UNHRC, 'Report of the Independent International Commission of Inquiry on the Syrian Arab Republic' (4 June 2013) UN Doc A/HRC/23/58

\section{Other}

Allied Control Council Law No. 10, Punishment of Persons Guilty of War

Crimes, Crimes against Peace and Humanity (20 December 1945) 3 Official

Gazette Control Council for Germany 50-55 (1946)

Charter of the International Military Tribunal (Nuremberg) annexed to

Agreement for the Prosecution and Punishment of the Major War Criminals of the European Axis (signed in London, 8 August 1945) 82 UNTS 279

Charter of the International Military Tribunal for the Far East (19 January

1946, amended 25 April 1946) TIAS No. 1589

Report of the Preparatory Committee for the Establishment of an International

Criminal Court - Draft Statute for the International Criminal Court (14 April

1998) UN Doc A/Conf.183/2/Add.1

Resolution RC.Res.6 adopted at the 13th Plenary Meeting, Review

Conference of the Rome Statute, Kampala, Uganda (11 June 2010)

International Commission of Jurists, 'Report of the Expert Panel on Corporate

Complicity in International Crimes' (Geneva 2008)

United Kingdom Parliament Joint Committee on Human Rights, Allegations

of UK Complicity in Torture (2008-09 HL Paper 152 HC 230)

European Commission for Democracy through Law, 'Opinion on the International Legal Obligations of Council of Europe Member States in Respect of Secret Detention Facilities and Inter-State Transport of Prisoners' adopted by the Venice Commission at its 66th Plenary Session (17 March 2005), Op. No. 363/2005

\section{Domestic Legislation}

Austria

StGB $\S 12$

United States of America

18 USC $\S 2(1994)$

11,28

Mo. Rev. Stat. § 575.230 (Mo)

Mo. Rev. Stat. § 575.210 (Mo) 


\section{Canada}

Crimes against Humanity and War Crimes Act 2000, s 5

\section{England}

Ordinance of Labourers (1349) 23 Edw. III

\section{England and Wales}

Accessories and Abettors Act 1861, as amended by Sched. 12 of the Criminal $11,28-29,105,143-$ Law Act 1977, s 8

International Criminal Court Act 2001, s 65

Merchant Shipping Act 1995, s 93

Serious Crime Act 2007, s 44

Serious Crime Act 2007, s 45

Serious Crime Act 2007, s 46

Germany

StGB $\S 25$

24,108

StGB $\S 26$ $25-26,30,34,87$, 108-109

StGB $§ 27$

$26,30,34,87,108$

StGB $\S 49$ 30,87

\section{Scotland}

International Criminal Court (Scotland) Act 2001, s 5 


\section{PART A. A THEORY OF COMPLICITY}

\section{CHAPTER 1. INTRODUCTION}

\subsection{INTRODUCTION}

Allegations of complicity are pervasive: France has been accused of complicity in the Rwandan genocide, ${ }^{1}$ China of complicity in atrocities in Darfur, ${ }^{2}$ Pakistan of complicity in the sheltering of Bin Laden, ${ }^{3}$ and the United Kingdom of complicity in torture during the war on terror. ${ }^{4}$ If these allegations tell us anything about the nature of complicity, it is that to be complicit one must be complicit in something. That something is the commission of wrongdoing by another actor. If that wrongdoing does not occur, there is nothing for the accomplice to be complicit in. ${ }^{5}$ This is the essential derivative nature of complicity. ${ }^{6}$

This thesis is concerned with the ways in which international law responds to individual and state complicity in wrongdoing committed by another actor.

Complicity rules take a variety of forms, ranging in source, content, and structure.

This thesis provides an analytical account of these rules, locating them within in a single analytical framework. The framework assumes that no matter the legal subject of the complicity rule, certain issues of scope and form must be confronted.

\footnotetext{
${ }^{1}$ Mike Pflanz, 'French Leaders Accused of Complicity in Rwanda Genocide' The Telegraph (London, 5 August 2008) <http://www.telegraph.co.uk/news/worldnews/2506150/France-accused-of-complicityin-Rwanda-genocide.html $>$ accessed 23 July 2013.

${ }^{2}$ Eric Reeves, 'Arming Khartoum: China's Complicity in the Darfur Genocide' Sudan Tribune (Paris, 19 October 2010) <http://www.sudantribune.com/spip.php?article36644> accessed 2 October 2013.

${ }^{3}$ Robert Baer, 'Finding Bin Laden Raises Questions About Pakistan's Complicity' Time (New York, 2 May 2011) <http://www.time.com/time/world/article/0,8599,2069012,00.html> accessed 23 July 2013.

${ }^{4}$ United Kingdom Parliament Joint Committee on Human Rights, Allegations of UK Complicity in Torture (2008-09) HL Paper 152 HC 230.

${ }^{5}$ Robert Weisberg, 'Reappraising Complicity’ (2000-2001) 4 Buff. Crim. L. Rev. 217, 224; John Quigley, 'Complicity in International Law: A New Direction in the Law of State Responsibility' (1986) 57 British YB Intl L. 77, 86.

${ }^{6}$ Sanford Kadish, 'Complicity, Cause and Blame' (1985) 73 Calif. L. Rev. 323, 337.
} 
Beyond this analytical account is a normative claim about the structure of complicity rules. Complicity is a particular mode of wrongdoing. Translated into law, this requires that doctrines of complicity give rise to responsibility and sanction for those very acts of complicity. Doctrines of complicity structured in this way may be termed 'non-imputational' complicity rules. A state that assists another state's commission of genocide should be held responsible for assisting genocide. It should not be held responsible for genocide. An individual who instigates another individual to commit war crimes should be held responsible for instigating war crimes. She should not be held responsible for war crimes. This is the normative claim of the thesis.

\subsection{THE STRUCTURE OF THE THESIS}

Part A of the thesis comprises Chapters 1 and 2. Chapter 1, the present chapter, is a general introduction. Chapter 2 addresses some matters of foundational concern for a study of complicity. It provides a definition of complicity, considers why complicity rules exist, defends the normative claim of the thesis concerning the structure of complicity rules, and builds the analytical framework of the thesis. That framework structures the analysis along three axes: the forms of complicity prohibited, the nexus between the accomplice's act and the principal's wrong, and the fault required of the accomplice.

Thereafter, the thesis is organised around the status of the complicit actor. Part B-comprising Chapters 3, 4 and 5-addresses individual complicity in international criminal law. After a brief assessment in Chapter 3 of the principle of 
individual criminal responsibility in international law, Chapter 4 analyses the two central complicity doctrines of instigation and aiding and abetting, placing them within the analytical framework of the thesis and evaluating their structure against the normative claim noted above. Chapter 5 assesses two ways that international criminal law deals with complicit omissions. First, it is now established that in a limited set of circumstances an omission may fulfill the conduct element of aiding and abetting as a mode of responsibility. Second, some complicit omissions give rise to liability under the doctrine of command responsibility.

Part $\mathrm{C}$ - comprising chapters 6 through 9-addresses state complicity. As will become clear, the idea of state complicity has historically had an uneasy relationship with the basic structures and assumptions of international law and state responsibility. These difficulties are noted in Chapter 6. To explain this unease and understand how international law has developed, it is helpful to distinguish (a) state participation in the conduct of another state, and (b) state participation in the conduct of a non-state actor.

In respect of the former, moving away from a historical absence of complicity rules, international law now prohibits various forms of state complicity in the wrongful conduct of another state. These are addressed in Chapter 7. Initially, specific complicity rules arose concerning state participation in a particular international wrong. This thesis analyses the specific complicity rule prohibiting state participation in the wrong of aggression. Subsequently, a general complicity rule arose prohibiting states from aiding or assisting another state in the commission of any international wrong. This is the rule reflected in Article 16 of the International 
Law Commission's Articles on Responsibility of States for Internationally Wrongful Acts (ARSIWA). ${ }^{7}$ Although one element of the general rule unduly limits its scope, it represents a leap in the 'moral sophistication of international law." 8

In respect of the latter-state participation in the conduct of non-state actorsthere has historically been a conceptual difficulty in assessing the state's participation as a form of complicity. Complicity is essentially derivative: it requires wrongdoing by the principal actor. ${ }^{9}$ Without any such wrongdoing, there is nothing for the complicit state to be complicit in. Even if the state is no longer the exclusive subject of international law, it has long been its primary subject. ${ }^{10}$ That is to say, the predominant bearer of rights and duties within the international legal system has traditionally been the state. ${ }^{11}$ The absence of direct regulation of the conduct of nonstate actors robbed international law of the possibility of state responsibility for complicity in that conduct. De Frouville takes up this point in explaining that the rejection of complicity 'simply follows from the classical structure of normativity in international law which is articulated around the obligations, the only subjects of which are States... ${ }^{12}$

It will be seen that some instances of state participation in the conduct of nonstate actors will give rise to state responsibility under various broader due diligence

\footnotetext{
${ }^{7}$ International Law Commission, 'Responsibility of States for Internationally Wrongful Acts' annexed to UNGA Res 56/83 (12 December 2001) UN Doc A/Res/56/83.

${ }^{8}$ Vaughan Lowe, 'Responsibility for the Conduct of Other States' (2002) 101 Japanese J. Intl L. 1, 12.

${ }^{9}$ Kadish, 'Complicity, Cause and Blame' 337.

${ }^{10}$ Robert Jennings and Arthur Watts, Oppenheim's International Law - Volume 1: Peace - Introduction and Part 1 ( $9^{\text {th }}$ ed., Longman 1996) 16.

${ }^{11}$ James Crawford, Brownlie's Principles of Public International Law (OUP 2012) 115.

${ }^{12}$ Olivier de Frouville, 'Attribution of Conduct to the State: Private Individuals' in James Crawford, Alain Pellet and Simon Olleson (eds), The Law of International Responsibility (OUP 2010) 257, 276.
} 
obligations that require states to protect against potential harms to other subjects of international law. These are not complicity rules, for there is no principal wrong on the international plane from which the state's responsibility is derived. ${ }^{13}$ Obligations of this kind are not of primary concern in this thesis; there is an extensive literature assessing their content and source. ${ }^{14}$ Instead, this thesis assesses two developments that affect the ways in which international law regulates the participation of states in the harms caused by non-state actors.

First, Chapter 8 addresses the claim that the idea of complicity has penetrated the rules of attribution in international law. It will be seen that in customary international law, attribution of conduct to the state is marked by the search for an agency relationship. A complicit relationship_one falling short of the direction and/or control required for agency — is ordinarily insufficient to attribute the conduct of a non-state actor to the state. ${ }^{15}$ In two contexts - terrorist attacks and human rights violations in the Inter-American system - there is a claim that a complicit relationship is sufficient for attribution. The thesis argues that this claim should be rejected.

Second, Chapter 9 explains that as international law has come to recognise conduct other than state conduct as internationally wrongful, so the conceptual

\footnotetext{
${ }^{13}$ De Frouville, 'Attribution of Conduct' 276-277.

${ }^{14}$ See Riccardo Pisillo-Mazzeschi, 'Due Diligence and the International Responsibility of States' (1992) 35 German YB Intl L. 9; Robert Barnidge, Non-State Actors and Terrorism: Applying the Law of State Responsibility and the Due Diligence Principle (TMC Asser 2008); Sarah Heathcote, 'State Omissions and Due Diligence: Aspects of Fault, Damage and Contribution to Injury in the Law of State Responsibility' in Karine Bannelier, Theodore Christakis and Sarah Heathcote (eds), The ICJ and the Evolution of International Law: The Enduring Impact of the Corfu Channel Case (Routledge 2012) 295.

${ }^{15}$ Art 8 ARSIWA; Application of the Convention on the Prevention and Punishment of the Crime of Genocide (Bosnia and Herzegovina v Serbia and Montenegro) (Merits) [2007] ICJ Rep 43 [398]-[407]; Tal Becker, Terrorism and the State (Hart 2006) 43-79; Christine Chinkin, Third Parties in International Law (OUP 1993) 142.
} 
possibilities for complicity have expanded. To put it bluntly, now that non-state actors can commit principal wrongs on the international plane, there is principal wrongdoing by non-state actors for states to be complicit in. ${ }^{16}$ On this basis, international law is able to articulate and condemn state complicity qua complicity. The best example of this development is the prohibition on state complicity in genocide.

Together, Parts B and $\mathrm{C}$ - Chapters 3 through 9-provide an analytical account of complicity in international law and a critique of the structure of the rules in accordance with the normative claim of the thesis. As a broad narrative, the ease with which international criminal law has sanctioned individual complicity may be contrasted with the historical inadequacy of international law's regulation of state complicity. That inadequacy is (almost) a thing of the past, at least with respect to state complicity in the wrongdoing of other states. Chapter 10 draws some general conclusions about the ways in which international law prohibits complicity.

\subsection{THE SCOPE OF THE THESIS}

As noted above, complicity is essentially derivative; its logic is to tie the participatory conduct of the accomplice to the wrongdoing of the principal actor. ${ }^{17}$ There is some terminological confusion in the literature on this point. Scholars sometimes use the term derivative to mean that the acts of the principal are imputed to the accomplice. ${ }^{18}$ Complicity doctrines structured in this way are better described as imputational complicity. Although complicity rules are always derivative in that for every act of

\footnotetext{
${ }^{16}$ De Frouville, 'Attribution of Conduct' 277.

${ }^{17}$ Kadish, 'Complicity, Cause and Blame' 337.

${ }^{18}$ See e.g. George Fletcher 'Complicity’ (1996) 30 Isr. L. Rev. 140.
} 
complicity there must be an act of principalship, they are not necessarily imputational. ${ }^{19}$ Accomplices may (and, in terms of the normative claim of the thesis, should) be held responsible for their own contribution to the principal wrong.

The essential derivative character of complicity explains the exclusion of certain related forms of responsibility from this thesis. Consider the obligation of non-refoulement in international law. The obligation commonly arises in respect of the prohibition of torture in international human rights law. ${ }^{20}$ Article 3 of the European Convention of Human Rights, for instance, prohibits deportation or extradition where there are substantial grounds for believing that the individual faces a real risk of torture or inhuman and degrading treatment in the receiving state. ${ }^{21}$ The breach of Article 3 arises at the moment of the deportation or extradition. Whether the wrongful treatment later occurs is immaterial. ${ }^{22}$ For this reason, non-refoulement is not a derivative form of responsibility and, consequently, is not a form of complicity per se. Instead, it may be thought of as a kindred form of responsibility ${ }^{23}$ that seeks to prevent contributions to wrongful conduct by introducing a general rule

\footnotetext{
${ }^{19}$ Cf Markus Dubber, 'Criminalizing Complicity: A Comparative Analysis' (2007) 5 J. Intl Crim. Justice 977, 993.

${ }^{20}$ Art 3(1) Convention against Torture and Other Cruel, Inhuman or Degrading Treatment or Punishment (adopted 10 December 1984, entered into force 26 June 1987) 1465 UNTS 85; UNHRC, 'General Comment 20' (10 March 1992) UN Doc HRI/GEN/1/Rev.1 30 (1994) [9]. See generally United Nations High Commissioner for Refugees, Legal Opinion of Sir Elihu Lauterpacht and Daniel Bethlehem, 'The Scope and Content of the Principle of Non-Refoulement.'

${ }^{21}$ See (European) Convention for the Protection of Human Rights and Fundamental Freedoms (adopted 4 November 1950, entered into force 3 September 1953; as amended) 213 UNTS 222; Soering $v$ United Kingdom (App 14038/88) (1989) 11 EHRR 439.

${ }^{22}$ Conversely, if the wrongful treatment does subsequently occur but there were no substantial grounds for believing there was a real risk thereof at the time of deportation or extradition, there is no responsibility under Article 3. See Mamatkulov and Askarov v Turkey (Apps 46827/99 \& 46951/99) (2005) 41 EHRR 25.

${ }^{23}$ KJM Smith, A Modern Treatise on the Law of Complicity (Clarendon 1991) 7.
} 
that responds to a risk of harm. ${ }^{24}$

Likewise, what might otherwise fulfill an ordinary mode or form of complicity may itself be prohibited directly. UN Security Council Resolution 418 of 1977 imposed an arms embargo on South Africa: 'all States shall cease forthwith any provision to South Africa of arms and related matérial of all types... ${ }^{25}$ Any such provision, which may also constitute aid or assistance under conventional doctrines of complicity where it is linked to a subsequent wrongful act, gives rise to direct state responsibility for breach of that obligation. ${ }^{26}$ This is not a form of derivative liability. Obligations of this kind are not the focus of the thesis.

In addition, for reasons of scope this thesis does not address a number of emerging topics and areas in international law related to, or even falling within, the idea of complicity. It does not address corporate complicity. ${ }^{27}$ It does not deal with the responsibility of international organisations. ${ }^{28}$ Although, of course, heightened forms of complicity at some point cross over into joint perpetration or commission,

\footnotetext{
${ }^{24}$ This is not to say that a state that deports or extradites an individual in the knowledge that she will be tortured would not be complicit in torture by the recipient state should the torture occur. In all likelihood the state would be responsible for complicity, in addition to its responsibility under the principle of non-refoulement. The point is that a breach of the non-refoulement obligation does not require the commission of wrongdoing by another actor.

${ }^{25}$ UNSC Res 418 (4 November 1977) UN Doc S/Res/418.

${ }^{26}$ See Roberto Ago, 'Seventh Report on State Responsibility - the Internationally Wrongful Act of the State, Source of International Responsibility' (1978) UN Doc. A/CN.4/307 (1978) I(1) YILC 31 [72].

${ }^{27}$ See generally International Commission of Jurists, 'Report of the Expert Panel on Corporate Complicity in International Crimes' (Geneva 2008); Andrew Clapham, 'Extending International Criminal Law beyond the Individual to Corporations and Armed Opposition Groups' (2008) 6 J. Intl Crim. Justice 899.

${ }^{28}$ See generally International Law Commission, 'Responsibility of International Organizations - Texts and Titles of Draft Articles 1 to 67 adopted by the Drafting Committee on Second Reading in 2011' (2011) UN Doc A/CN.4/L.778; Pierre Klein, 'Attribution of Acts to International Organizations' in Crawford et al, The Law of International Responsibility 297; Nataša Nedeski \& André Nollkaemper, 'Responsibility of International Organizations "in Connection with Acts of States"' (2012) 9 Intl Org. L. Rev. 33 .
} 
this thesis does not address the ways in which international law holds states or individuals jointly responsible. ${ }^{29}$ The thesis does not deal with situations where a state directs and controls the commission of an internationally wrongful act by another state, ${ }^{30}$ or indeed coerces such an act. ${ }^{31}$ Moreover, it does not provide a comprehensive overview of state practice relating to state complicity ${ }^{32}$ or of the modes of responsibility in international criminal law. ${ }^{33}$

Instead, this thesis seeks to understand how international law prohibits core instances of state and individual complicity. It places the rules in a single analytical framework based on the kinds of complicit conduct prohibited, the nexus between the accomplice's acts and the principal's wrong, and the fault of the accomplice, and evaluates the structure the accomplice's responsibility against the normative claim of the thesis. In doing so, it also provides a narrative account of how international law increasingly regulates different forms of individual and state complicity.

\footnotetext{
${ }^{29}$ See generally Smith, A Treatise on Complicity 209-234; Jens Ohlin, 'Joint Intentions to Commit International Crimes' (2010-2011) 11 Chicago J. Intl L. 693; Jens Ohlin, Elies van Sliedregt and Thomas Weigend, ‘Assessing the Control Theory' (2013) 26 Leiden J. Intl L. 725; John Noyes and Brian Smith, 'State Responsibility and the Principle of Joint and Several Liability' (1998) 13 Yale J. Intl L. 225; Stefan Talmon, 'A Plurality of Responsible Actors - International Responsibility for Acts of the Coalition Provision Authority in Iraq' in Phil Shiner and Andrew Williams, The Iraq War and International Law (Hart 2008) 185; Francesco Messineo, 'Multiple Attribution of Conduct' SHARES Research Paper No. 2012-11; André Nollkaemper and Dov Jacobs, 'Shared Responsibility in International Law: A Conceptual Framework’ (2012/2013) 34 Mich. J. Intl L. 359.

${ }^{30}$ See Art 17 ARSIWA.

${ }^{31}$ See Art 18 ARSIWA.

${ }^{32}$ See Quigley, 'Complicity in International Law' 81-107; Helmut Aust, Complicity and the Law of State Responsibility (CUP 2011) 97-191.

${ }^{33}$ See Gideon Boas, James Bischoff and Natalie Reid, Forms of Responsibility in International Criminal Law - International Criminal Law Practitioner Library Series: Volume I (CUP 2007); Elies van Sliedregt, Individual Criminal Responsibility in International Law (OUP 2012).
} 


\section{CHAPTER 2. THE STRUCTURE OF COMPLICITY}

\subsection{INTRODUCTION}

This chapter addresses four matters of foundational concern for a study of complicity. First, it provides a definition of complicity. Second, it explores the wrongness of complicity. Third, it considers the different ways that legal systems prohibit complicit conduct; that is to say, it assesses how complicity rules may be structured. That assessment gives rise to a preference for non-imputational complicity rules. This is the normative claim of the thesis. Fourth, it builds the analytical framework in which the rules arising in international law will be discussed. The framework consists of three issues that must be resolved whenever complicity is prohibited: the forms of complicity proscribed, the nexus between the accomplice's conduct and the principal's wrong, and the fault required of the accomplice.

\subsection{A DEFINITION OF COMPLICITY}

In conventional usage, the idea of complicity is widely understood. At root, it concerns an actor's participation in wrongdoing committed by another actor. ${ }^{34}$ In building a definition of complicity, it is helpful to look to criminal law, for it is here that complicity receives most attention. ${ }^{35}$ In criminal law, a common approach to complicity is to proscribe certain kinds of behaviour that constitute participation in another's acts. A broad range of terms is used to sanction participation in this way. The federal complicity rule in the United States refers to those who aid, abet, counsel,

\footnotetext{
${ }^{34}$ Smith, A Treatise on Complicity 1-2.

${ }^{35}$ See e.g. Smith, A Treatise on Complicity; Kadish, 'Complicity, Cause and Blame'; Joshua Dressler, 'Reassessing the Theoretical Underpinnings of Accomplice Liability: New Solutions to an Old Problem (1985-1986) 37 Hastings L. J. 91; Weisberg, 'Reappraising Complicity'; Andrew Simester, 'The Mental Element in Complicity' (2006) 122 LQR 578; Robert Sullivan, 'Conduct and Complicity: Liability based on Omission and Risk' (2008) 39 Cambrian L. Rev. 60.
} 
command, induce, or procure the commission of an offence. ${ }^{36}$ In England and Wales, the Accessories and Abettors Act of 1861 refers to aiders, abettors, counsellors, and procurers. ${ }^{37}$ Older sources reveal prohibitions on helping, giving comfort, and assisting. ${ }^{38}$ There is also reference to advising, persuading, inducing, and soliciting. ${ }^{39}$ These may be termed modes or forms of complicity. ${ }^{40}$ There is a risk of spending too much time on a literal construction of these terms. ${ }^{41}$ Rather, it should be recognised that together these terms attempt to prohibit complicity as a particular mode of wrongdoing.

That mode of wrongdoing is best thought of as comprising two kinds of action: intentionally helping the principal to commit wrongdoing and intentionally influencing the decision of the principal to commit the wrong. ${ }^{42}$ There is a temporal issue here. Despite linguistic similarities, the doctrine of accessory after the fact should not be regarded as a form of complicity. ${ }^{43}$ This form of liability is a remnant of an ancient concern with receiving a felon or shielding him from justice. ${ }^{44}$ Even in Blackstone's time, the crime of being an accessory after the fact was 'always an offence of a different species of guilt, principally tending to evade the public

\footnotetext{
${ }^{36} 18$ USC $\S 2$ (1994) (USA).

${ }^{37}$ Accessories and Abettors Act 1861, as amended by Sched. 12 of the Criminal Law Act 1977, s. 8.

${ }^{38}$ Smith, A Treatise on Complicity 31.

${ }^{39}$ Kadish, 'Complicity, Cause and Blame' 343.

${ }^{40}$ Smith, A Treatise on Complicity 20.

${ }^{41}$ Ibid 33.

${ }^{42}$ Kadish, 'Complicity, Cause and Blame' 342.

${ }^{43}$ Smith, A Treatise on Complicity 7.

${ }^{44}$ Glanville Williams, Criminal Law - The General Part (2 ${ }^{\text {nd }}$ ed., Stevens \& Sons 1961) 409-410.
} 
justice... ${ }^{45}$ Accessories after the fact do not help or influence the principal in his commission of wrongdoing - they make no contribution to the wrong itself. ${ }^{46}$

That criminal law is the context in which ideas of complicity usually arise should not be seen to exclude their application to other areas of law. At root, complicity is simply a derivative form of responsibility for participation in wrongdoing committed by another actor. Wrongdoing, in this sense, may refer to the commission of any legal wrong, whether equitable, criminal, tortious, or international. This definition frames the thesis' account of complicity in international law, delineating the rules to be included and excluded.

\subsection{THE WRONGNESS OF COMPLICITY}

\subsubsection{Moral and Legal Wrongs}

On one level, the case for complicity rules is a moral case. It rests on the claim that if it is wrong to do something, it is wrong to help or encourage others to do it. Gardner argues that:

I am responsible for what I do, and you are responsible for what you do. But on any credible view I need to give attention, in what I do, to what you will do in consequence. And you need to give attention, in what you do, to what I will do in consequence. In that sense, there are two parts of morality. There is what I should do simpliciter, and then there is what I should do by way of contribution to what you do. If I fail in the first I am a principal. If I fail in the second I am an accomplice. ${ }^{47}$

\footnotetext{
${ }^{45} 4 \mathrm{Bl}$ Comm 40. See also Smith, A Treatise on Complicity 7-8.

${ }^{46}$ The boundary between accomplice liability and liability as an accessory after the fact in international criminal law is explored in Chapter 4.3.2. See Strugar (Trial Chamber Judgment) IT-01-42-T (31 January 2005) and Blagojević, Jokić (Trial Chamber Judgment) IT-02-60-T (17 January 2005).

${ }^{47}$ John Gardner, 'Complicity and Causality’ (2007) 1 Crim. L. \& Phil. 127, 132.
} 
On this account, the wrongness of the principal's act justifies a prohibition of complicity. A justification of this kind is most easily understood in the context of criminal law. Clearly, a number of criminal offences prohibit conduct that is morally wrong: murder, for instance, is malum in se. ${ }^{48}$ More than simply justifying the existence of a complicity rule, the wrongness of the principal act requires it. Here, a prohibition of complicity — concern not just with what subjects do to each other but with what they help or encourage others to do - is a sign of the moral sophistication of a legal system. ${ }^{49}$

The justification and requirement of complicity rules on a basis other than the moral wrongness of the principal act requires further thought. In these cases, we are confined to saying that the principal, helped or encouraged by the accomplice, committed a legal wrong against the victim. Here, it is helpful to distinguish two different relationships among the three parties ( $\mathrm{V}$ being the victim, $\mathrm{P}$ the principal, and A the accomplice):
A. V has a right exigible against both $\mathrm{P}$ and $\mathrm{A}$. P, helped or encouraged by A, violates the correlative duty;
B. V has a right exigible against $\mathrm{P}$ only. $\mathrm{P}$, helped or encouraged by $\mathrm{A}$, violates the correlative duty. ${ }^{50}$

In both cases $\mathrm{P}$ violates the duty, though only in the former was the correlative right held by $\mathrm{V}$ also exigible against $\mathrm{A}$. This distinction is important in considering whether complicity rules are justified and/or required.

\footnotetext{
${ }^{48}$ See B1 Comm 54.

${ }^{49}$ Lowe, 'Responsibility for the Conduct of Other States' 12. See also Gardner, 'Complicity and Causality' 132.

${ }^{50}$ This distinction borrows from, but does not match, Hohfeld's distinction between paucital and multital rights. See Wesley Hohfeld, 'Fundamental Legal Conceptions as Applied in Judicial Reasoning' (1916-1917) 26 Yale L. J. 710, 718-719.
} 
In the former case, the shared legal obligation owed by $\mathrm{P}$ and $\mathrm{A}$ to $\mathrm{V}$ itself demands that A does not help or encourage P's violation of that obligation. There is an intuitive plausibility to this claim — as the International Law Commission puts it, one "cannot do by another what [one] cannot do by [oneself]. ${ }^{51}$ As a general principle, this holds across the range of obligations arising in domestic and international law. It should be noted, however, that the exact content of the complicity prohibition might vary according to the nature of the principal obligation. A useful illustration in this regard is the difference between complicity in municipal criminal law and the law of torts. ${ }^{52}$ In England and Wales, for instance, accomplice liability in tort law requires a higher form of participation in the wrong than criminal law; knowing assistance is insufficient. ${ }^{53}$

The second situation — where only $\mathrm{P}$ is under a duty to $\mathrm{V}$ - is more complicated. It is best illustrated through contractual duties in municipal law. Imagine $\mathrm{P}$ and $\mathrm{V}$ contract. $\mathrm{P}$ is under a contractual duty to refrain from building any structure within view of V's property. A, who is aware of the contract, then helps or encourages $\mathrm{P}$ to build such a prohibited structure. In a general sense, we may say that A is complicit in P's violation of his legal duty.

Whether this is the kind of complicity that the legal system ought to prohibit is a difficult question. It is fundamental that a contract does not impose obligations on

\footnotetext{
${ }^{51}$ ARSIWA Commentary on Art 16 [6].

52 See Hazel Carty, 'Joint Tortfeasance and Assistance Liability' (1999) 19 Legal Stud. 489; Paul Davies, 'Accessory Liability for Assisting Torts' (2011) 70 Camb. L. J. 353; Joachim Dietrich, 'Accessorial Liability in the Law of Torts' (2011) 31 Legal Stud. 231. See also Robert Stevens, Torts and Rights (OUP 2007) 275-283.

${ }^{53}$ Davies, 'Accessory Liability for Assisting Torts' 357-358; Dietrich, 'Accessorial Liability in the Law of Torts' 239.
} 
third parties. P's voluntary assumption of a duty towards $\mathrm{V}$ does not give rise to a duty owed by $\mathrm{A}$ (or $\mathrm{B}, \mathrm{C}$, or $\mathrm{D}$ ) to $\mathrm{V} .{ }^{54}$ Correlatively, $\mathrm{V}$ has no right arising under the contract exigible against A (or B, C, or D). This rule of privity flows from the consensual nature of contractual obligations. ${ }^{55}$ In the context of treaties in international law, the same idea is captured by the pacta tertiis rule- - a treaty does not create obligations on a third state without its consent. ${ }^{56}$ However, appeals to privity or the pacta tertiis rule should not be the end of the matter. As Hohfeld puts it: 'Whether there should be such concomitant rights (or claims) is ultimately a question of justice and policy; and it should be considered, as such, on its merits. ${ }^{, 57}$

\subsubsection{An Analogy to Inducing Breach of Contract}

Whether or not public international law should prohibit state complicity in the breach by another state of an international obligation binding only it (and not the potentially complicit state) is a central question in Chapter 7 of this thesis. It will be seen that the rule reflected in Article 16 ARSIWA denies the existence of any such prohibition. At this point, a tentative analogy might be drawn to the tort of inducing breach of contract in England and Wales. ${ }^{58}$ It is tentative because of differences between the legal subjects of the rules, the nature of responsibility, and the underlying principles, structures and purposes of the legal systems. Nonetheless, it is helpful in illustrating

\footnotetext{
${ }^{54}$ See Wesley Hohfeld, 'Some Fundamental Legal Conceptions as Applied in Judicial Reasoning (1913-1914) 23 Yale L. J. 16, 36-37.

${ }^{55}$ See Edwin Peel, Treitel's Law of Contract (13 ${ }^{\text {th }}$ ed., Sweet and Maxwell 2011) 621.

${ }^{56}$ Art 34 Vienna Convention on the Law of Treaties (adopted 23 May 1969, entered into force 27 January 1980) 1155 UNTS 331 (VCLT). See Vaughan Lowe, International Law (OUP 2011) 81-86.

${ }^{57}$ Hohfeld, 'Some Fundamental Legal Conceptions' 36.

${ }^{58}$ For a comparative perspective, see e.g. Peter Eulau, 'Inducing Breach of Contract: A Comparison of the Laws of the United States, France, The Federal Republic of Germany and Switzerland' (1978) 2 Boston College Intl \& Comp. L. Rev. 41; James Crawford, 'Second Report on State Responsibility Annex: Interference with Contractual Rights: A Brief Review of the Comparative Law Experience' (1999) UN Doc A/CN.4/498/Add.3.
} 
how questions of justice and policy that inform the desirability of a complicity rule play out in a particular legal context.

Although the tort's antecedents may be traced to the Roman actio indirecta, ${ }^{59}$ in England and Wales the Statute of Labourers of 1349 sheds more light on the issue. Issued by Edward III in the midst of the Black Death, the statute sought to compel labourers to work at fixed prices. ${ }^{60}$ In addition, it provided:

[i]f any reaper, mower, or other workman or servant, of what estate or condition that he be, retained in any man's service, do depart from the said service without reasonable cause or license, before the term agreed, he shall have pain of imprisonment. And that none under the same pain presume to receive or to retain any such in his service. ${ }^{61}$

As Sayre explains, one effect of this provision was to create a new statutory remedy available against a third party for enticing another man's servant away from his service, the prevailing concern being the labour shortage caused by the Black Death. ${ }^{62}$ That is to say that at the time, the relationship between master and labourer was thought by the law-giver to be of such importance that third party interference with that relationship warranted an additional remedy. ${ }^{63}$

This is how we should understand the landmark common law inducement case of Lumley $v$ Gye. ${ }^{64}$ As is well-known, Johanna Wagner, a famous opera singer, contracted with Lumley, the manager of Her Majesty's Theatre, Haymarket, to

\footnotetext{
${ }^{59}$ See Francis Sayre, 'Inducing Breach of Contract' (1922-1923) 36 Harv. L. Rev. 663; Hazel Carty, An Analysis of the Economic Torts ( $2^{\text {nd }}$ ed., OUP 2010) 30.

${ }^{60}$ (1349) 23 Edw. III.

${ }^{61}$ Ibid.

${ }^{62}$ Sayre, 'Inducing Breach of Contract' 665-666.

${ }^{63}$ See Lumley $v$ Gye [1853] 118 ER 749, 765 (Coleridge J). This is to say nothing of the morality or wisdom of the Statute.

${ }^{64}[1853] 118$ ER 749.
} 
perform exclusively at his theatre. ${ }^{65}$ Gye, the manager of a rival opera house, made Wagner a more attractive offer. Wagner accepted the offer. In his dissenting judgment, Coleridge $\mathrm{J}$ denied the possibility of an action in tort:

...in respect of breach of contract the general rule of our law is to confine its remedies by action to the contracting parties...; that, as between master and servant, there is an admitted exception; that this exception dates from the Statute of Labourers, 23 Edw. 3, and both on principle and according to authority is limited by it. ${ }^{66}$

Coleridge's dissent represented conventional understandings of the law in 1853: other than the master and servant cases deriving from the Statute of Labourers, no remedy lay against a complicit third party to a breach of contract. ${ }^{67}$ The majority disagreed, holding that principle and public policy demanded that Lumley's contractual relations with Wagner be protected even against a third party. ${ }^{68}$ As Crompton J put it, 'it would seem unjust, and contrary to the general principles of law, if such wrongdoer were not responsible for the damage caused by his wrongful and malicious act. ${ }^{69}$ The court thereby 'freed the old enticement action from its roots in status relations. ${ }^{70}$

To emphasise, the reading of Lumley $v$ Gye presented here sees the tort of inducing breach of contract as a way to sanction an accomplice's participation in the breach of a legal duty owed by the principal. It sanctions a particular form of

\footnotetext{
${ }^{65}$ For a historical account, see S.M. Waddams, 'Johanna Wagner and the Rival Opera Houses' (2001) 117 LQR 431.

${ }^{66}$ Lumley (Coleridge J) 760.

${ }^{67}$ Sayre, 'Inducing Breach of Contract' 666.

${ }^{68}$ Lumley (Crompton J) 755. See Waddams, 'Johanna Wagner' 450.

${ }^{69}$ Lumley (Crompton J) 755. It should be noted that in the end Lumley did not prevail in his action. See Waddams, 'Johanna Wagner' 456-456.

${ }^{70}$ John Danforth, ‘Tortious Interference with Contract: A Reassertion of Society's Interest in Commercial Stability and Contractual Integrity’ (1981) 81 Colum. L. Rev. 1491, 1495
} 
complicity—inducement or procurement—with a particular mental state—knowledge of the contract and intention to cause a breach of that contract. ${ }^{71}$ It is derivative, in the sense that without the breach of contract committed by the principal there can be no liability for tortious inducement of that breach. ${ }^{72}$ It is a private law analogue of doctrines of complicity in criminal law.

So complicity rules arise in surprising places. There is another lesson in these inducement cases, one relevant to the evaluation of Article 16 ARSIWA in Chapter 7 of the thesis. It is that the desirability of a prohibition on complicity outside of criminal law cannot be settled by appeals to privity of contract or the pacta tertiis rule. ${ }^{73}$ Instead, we should weigh up principled and policy reasons, specific to the particular legal system, for and against holding the accomplice responsible. ${ }^{74}$

In the context of inducing breach of contract, these are manifold. Some argue that the value of the primary contractual relationship between $\mathrm{P}$ and $\mathrm{V}$ is so great as to require special protection from third parties. ${ }^{75}$ This protection may be explained by analogy to the law of property, such that V's right under the contract is treated 'as a species of property which deserve(s) special protection... ${ }^{76}$ An alternative

\footnotetext{
${ }^{71}$ See Carty, An Analysis of the Economic Torts 35-45

${ }^{72}$ OBG Limited and Others $v$ Allan and Others [2008] 1 AC 1 [8] (Lord Hoffmann): '...Lumley $v$ Gye created accessory liability, dependent upon the primary wrongful act of the contracting party.'

${ }^{73}$ See Hohfeld, 'Some Fundamental Legal Conceptions' 36; Waddams, 'Johanna Wagner' 451.

${ }^{74}$ Sayre, 'Inducing Breach of Contract' 687; Andrew Simester and Winnie Chan, 'Inducing Breach of Contract: One Tort or Two’ (2004) 63 Camb. L. J. 132, 139.

${ }^{75}$ See Roderick Bagshaw, 'Can the Economic Torts be Unified' (1998) 18 OJLS 729, 735; Carty, An Analysis of the Economic Torts 55.

${ }^{76} O B G v$ Allan [32] (Lord Hoffmann). See Richard Epstein, 'Inducement of Breach of Contract as a Problem of Ostensible Ownership' (1987) 16 J. Legal Stud. 1; Pey-Woan Lee, 'Inducing Breach of Contract, Conversion and Contract as Property’ (2009) 29 OJLS 511; Carty, An Analysis of the Economic Torts 55.
} 
conception is that the power to contract itself gives rise to a secondary right against all third parties that they not induce a breach of the contract. ${ }^{77}$ Other arguments look to the wrongdoing of the complicit third party ${ }^{78}$ or a broader societal interest in the integrity of contractual relations in a market economy. ${ }^{79}$ As Danforth puts it:

By extending the enticement action to allow tort protection against interference with contract, the court in Lumley $v$ Gye implicitly recognized that in 1853 society's interest in a stable foundation for economic activity had shifted from a concern for stability in status relations to a concern for stability in contractual relations. ${ }^{80}$

Against these justifications is the claim that the tort action unduly limits the interests of third parties in ordinary commercial activities. ${ }^{81}$ More broadly, in Sayre's phrasing, at stake here is the "very freedom of individual action which the common law exists largely to secure. ${ }^{82}$ On an efficient breach theory of contract, it is argued, though not without contestation, ${ }^{83}$ that the tort liability of the third party inducer limits the efficient allocation of resources. ${ }^{84}$ Others look to how the tort plays out in the particular context of labour relations. ${ }^{85}$

This is not the place to judge the desirability of the inducement tort. Instead, the tort serves to illustrate how ideas of complicity arise outside of criminal law and

\footnotetext{
${ }^{77}$ Stevens, Torts and Rights 281.

${ }^{78}$ See Lumley (Crompton J) 755; Sayre, 'Inducing Breach of Contract' 672-686.

${ }^{79}$ Danforth, 'Tortious Interference with Contract' 1509.

${ }^{80}$ Ibid.

${ }^{81}$ Sayre, 'Inducing Breach of Contract' 687; Harvey Perlman, 'Interference with Contract and Other Economic Expectancies: A Clash of Tort and Contract Doctrine' (1982) 49 Uni. Chicago L. Rev. 61, 78-79.

${ }^{82}$ Sayre, 'Inducing Breach of Contract' 687. See also Dan Dobbs, 'Tortious Interference with Contractual Relationships' (1980) 34 Ark. L. Rev. 335, 350.

${ }^{83}$ See generally Fred McChesney, 'Tortious Interference with Contract versus "Efficient” Breach: Theory and Empirical Evidence’ (1999) 28 J. of Legal Stud. 131.

${ }^{84}$ Perlman, 'Interference with Contract' 78-87.

${ }^{85}$ David Howarth, 'Against Lumley v Gye' (2005) 68 MLR 195.
} 
that the desirability and/or demand for complicity rules turn on conflicting rationales shaped by the needs and purposes of the legal system itself. In addition, these conflicting rationales shape the breadth of the complicity rule, determining the forms of complicity prohibited, the requisite nexus between the accomplice's act and the principal's wrong, and the fault of the accomplice. Complicity rules are not monolithic. Moreover, they may not be required to prohibit every form of participation in every legal wrong. These two points are important in considering the existence and forms of complicity appropriate to public international law.

\subsection{Structuring COMPlicity RuleS}

\subsubsection{Participation in Wrongdoing}

States cooperate with each other and with non-state actors all the time, often virtuously but sometimes wrongfully. Likewise, international crimes are marked by their collectivity; orders are given, plans made, weapons provided, detainees rounded up, and only then does someone pull the trigger. ${ }^{86}$ There are many ways to participate in wrongdoing. This much is beyond dispute.

What is in dispute is how to hold those participants responsible. Here, again, it makes sense to look to criminal law, where questions of participation have long been in issue. The conventional theoretical framework in criminal law distinguishes two basic models: unitary and differentiated participation. ${ }^{87}$ The unitary model is constituted by an expansive notion of principalship, imposing that label on all those

\footnotetext{
${ }^{86}$ See Tadić (Appeals Chamber Judgment) IT-94-1A (15 July 1999) [191]; Mark Osiel, 'The Banality of Good: Aligning Incentives Against Mass Atrocities’'(2005) 105 Colum. L. Rev. 1751.

${ }^{87}$ Albin Eser, 'Individual Criminal Responsibility' in Antonio Cassese, Paola Gaeta and John Jones (eds), The Rome Statute of the International Criminal Court: A Commentary - Vol 1 (OUP 2002), 767, 781-783.
} 
who make a causal contribution to the crime. ${ }^{88}$ Section 12 of the Austrian Penal Code, for instance, provides that an act is committed not only by the physical perpetrator but also by those who instigate or contribute to it. ${ }^{89}$ Other than at sentencing, the unitary model denies any need for distinguishing between participants in wrongdoing. There are no accomplices; all are principals.

A unitary model of participation is inconsistent with how we do, and ought to, think about responsibility. To borrow Darryl Robinson's example, the groom, bartender, and guest are all participants in a wedding. Indeed, they may all causally contribute to it. But we would not deny profound differences in their roles. ${ }^{90}$ Likewise, in the context of wrongdoing, complicity is a necessary element of a complete account of morality and responsibility. Gardner argues that 'the distinction between principals and accomplices is embedded in the structure of rational agency. As rational beings we cannot live without it. ${ }^{91}$ There are two elements to Gardner's account. The first concerns the wrongness of complicity: we should be concerned with not only the harms we do ourselves but also those we help or influence others to do. ${ }^{92}$ The second concerns the scope of that wrong. Being responsible for what we help or influence others to do is not the same as being responsible for what they do.

\footnotetext{
${ }^{88}$ Ibid 781

${ }^{89}$ StGB $\S 12$ (Austria). See Kai Ambos, 'Is the Development of a Common Substantive Criminal Law for Europe Possible? Some Preliminary Reflections’ (2005) 12 Maastricht J. of Eur. \& Comp. L. 173, 184.

${ }^{90}$ Darryl Robinson, 'Comment on Opinio Juris LJIL Symposium on James Stewart, The End of "Modes of Liability” for International Crimes - James Stewart Responds to Darryl Robinson' (Opinio Juris, 21 March 2012) <http://opiniojuris.org/2012/03/21/1jil-stewart-responds-to-robinson/> accessed 24 July 2013.

${ }^{91}$ Gardner, 'Complicity and Causality' 132.

${ }^{92}$ See also Lowe, 'Responsibility for the Conduct of Other States' 13.
} 
Another way of putting this is that the principal's wrong should not be imputed to the accomplice. Imputational complicity rules hold accomplices responsible for the wrongs of their principals. As discussed below, this is the approach in the United States and England and Wales. ${ }^{93}$ It should be conceded that complicity rules structured in this way enjoy some advantages. For one, they provide a forensic benefit, ${ }^{94}$ as it can be difficult to identify the precise contribution made by each one of a number of participants to a certain wrong. ${ }^{95}$ Although a robust doctrine of joint venture may mitigate this difficulty, there may still be evidentiary uncertainty as to the particular roles played by participants in wrongdoing. ${ }^{96}$ Imputational complicity renders this uncertainty less consequential in that the actor invoking or proving responsibility need only establish that a particular participant aided or encouraged the commission of the wrong. In addition, imputational rules directly connect accomplices to the harm that they help to bring about. In doing so, the condemnatory element of law is heightened. ${ }^{97}$

However, these advantages cannot overcome principled objections to imputational complicity. Where the subject of the rule is a person, decisions about responsibility implicate the principle of autonomy — recognition of moral agency. ${ }^{98}$ In

\footnotetext{
${ }^{93}$ See Ch. 2.4 .2 below.

${ }^{94}$ William Wilson, ‘A Rational Scheme of Liability for Participating in Crime' (2008) Crim. L. Rev. 3.

${ }^{95}$ Law Commission, Inchoate Liability for Assisting and Encouraging Crime (Law Com No 300, 2006) [2.10].

${ }^{96}$ See Smith, A Treatise on Complicity 27-30.

${ }^{97}$ KJM Smith, 'The Law Commission Consultation Paper on Complicity: Part 1: A Blueprint for Rationalism’ (1994) Crim. L. Rev. 239, 244.

${ }^{98}$ Andrew Ashworth, Principles of Criminal Law (6 ${ }^{\text {th }}$ ed. OUP 2009) 23-24.
} 
this context, autonomy sustains a principle of culpability, which demands that agents are held responsible for their own wrongdoing. ${ }^{99}$

Where the subject of the rule is a state, the recognition of international legal personality is premised on an analogous idea. It is foundational in international law that state responsibility requires that conduct (i) is attributable to the state, and (ii) constitutes a breach of the state's international obligations. ${ }^{100}$ This flows from the principle of sovereignty in international law. As Nollkaemper and Jacobs explain:

Sovereignty implies that a state is not responsible for acts of another state (or more generally another legal person). Just as international criminal law rejects the concepts of collective responsibility or guilt by association, instead relying on the principle of individual autonomy to limit responsibility to individuals only for their actual conduct, states resist principles of responsibility that require them to be responsible for conduct other than their own. ${ }^{101}$

States are right to resist any such principles of responsibility. In addition, holding accomplices responsible for the principal's wrong conflicts with the principle of fair labelling. ${ }^{102}$ In terms of the law's declarative function, it is crucial to accurately label wrongdoing. ${ }^{103}$ Moreover, it is a matter of fairness to wrongdoers that their conduct is accurately labeled and condemned. ${ }^{104}$ In imputational systems, an accomplice who knowingly gives a victim's whereabouts to a murderer is held

\footnotetext{
${ }^{99}$ Mirjan Damaška, 'The Shadow Side of Command Responsibility' (2001) 49 Am. J. of Comp. L. 455, 464; Joshua Dressler, 'Reforming Complicity Law: Trivial Assistance as a Lesser Offence' (2008) 5 Ohio State J. of Crim. L. 427, 434-435.

${ }^{100}$ Art 2 ARSIWA.

${ }^{101}$ Nollkaemper and Jacobs, 'Shared Responsibility in International Law’ 386.

${ }^{102}$ For an in-depth discussion, see James Chalmers and Fiona Leverick, 'Fair Labelling in Criminal Law' (2008) 71 MLR 217.

${ }^{103}$ Ashworth, Principles of Criminal Law 78.

${ }^{104}$ Ibid.
} 
responsible as a murderer, even though she did not, in fact, commit murder. ${ }^{105} \mathrm{~A}$ more accurate description of her wrongdoing might be defined as assisting murder or facilitating murder. ${ }^{106}$ A state that knowingly provides weapons to the principal state to commit an act of genocide would be held responsible for that act of genocide, rather than for its own wrong of assisting or facilitating genocide.

So complicity is a particular mode of wrongdoing - a way of participating in the wrong committed by another actor. In accounting for complicity in law, there are principled reasons for holding accomplices responsible for their own contribution to the principal's wrong, rather than for the wrong itself. In criminal law, the central means of achieving this end is through a differentiated model of participation in wrongdoing. A differentiated model of participation distinguishes principals from other participants in the wrong. ${ }^{107}$ The German Criminal Code is illustrative. Section 25 encompasses three forms of principalship. ${ }^{108}$ The central form is direct perpetration - the person commits the offence himself. ${ }^{109}$ Related to this is coperpetration - two or more people jointly engage in the proscribed conduct. ${ }^{110}$ The third form is indirect perpetration — a person commits the crime through another person. ${ }^{111}$ Underpinning the three categories is the concept of Tatherrschaft-

\footnotetext{
${ }^{105}$ Dressler, 'Reforming Complicity Law' 433.

${ }^{106}$ See Daniel Yeager, 'Helping, Doing, and the Grammar of Complicity' (1996) 15 Crim. Just. Eth. 25.

${ }^{107}$ Eser, ‘Individual Criminal Responsibility’ 782.

${ }^{108} \mathrm{StGB} \S 25$.

${ }^{109} \mathrm{StGB} \S 25(1)$.

${ }^{110} \mathrm{StGB} \S 25(2)$; Dubber, ‘Criminalizing Complicity’ 979.

${ }^{111} \mathrm{StGB} \S 25(1)$.
} 
dominion over the act. ${ }^{112}$ Dominion over the act is used to draw the line between principals and accomplices. ${ }^{113}$

The concept of Tatherrschaft is not the only way to distinguish principalship from secondary participation. Tatherrschaft is a normative model of principalship, its organising device a judgment about responsibility. ${ }^{114}$ Other normative models exist, with varying moral considerations built into the theory of agency. At the other end of a continuum is a naturalistic model, which looks to the actual course of events in the natural world. ${ }^{115}$ The principal is she who does the deed or causes the proscribed result. In assigning individual criminal responsibility, a naturalistic model starts with the person who pulls the trigger and considers the range of reprehensible relationships to that crime. ${ }^{116}$ It should be conceded, however, that a naturalistic model is still faced with difficult questions about what it means to 'do the deed' or 'cause the result.'

The role of accomplice liability obviously shifts in accordance with the breadth of principalship. In the German system, complicity is predominantly accounted for in two provisions. Section 26 establishes the responsibility of instigators - those who induce another to commit an unlawful act. ${ }^{117}$ Complicity in

\footnotetext{
${ }^{112}$ Dubber, 'Criminalizing Complicity' 981.

113 Ibid.

${ }^{114}$ Van Sliedregt, Individual Criminal Responsibility 72; Joachim Vogel, 'How to Determine Individual Criminal Responsibility in Systemic Contexts: Twelve Models' (2002) Cahiers de Défense Sociale 151, 155.

${ }^{115}$ Van Sliedregt, Individual Criminal Responsibility 71.

${ }^{116}$ Vogel, 'Twelve Models' 154-155. Of course, the substantive crime - or the deed-may itself be defined broadly, rendering participants principals in terms of its definition.

${ }^{117}$ StGB $§ 26$.
} 
this form is a matter of psychological influence. ${ }^{118}$ Section 27 establishes the responsibility of aiders. ${ }^{119}$ Here, the concern is primarily with the provision of assistance, though residual forms of psychological influence also fall within Section $27 .^{120}$ So the German differentiated model of participation comprises three forms of principalship, bounded by a theory of dominion over the act, and two forms of accomplice liability. This is not the only way to define either principalship or accomplice liability in criminal law. Conceptually, a differentiated model is limited only by the variety of words we have to describe the ways we may participate in crime. Crimes may be ordered, solicited, or induced, facilitated, aided, or abetted, procured, advised, or assisted. Crimes may be tolerated, sanctioned, or permitted.

The ways in which different forms of complicity are ordinarily prohibited are assessed in section 2.5.2 below. What is important is the structure of the differentiated system. A pure differentiated model of participation in crime distinguishes among participants at the level of attribution of responsibility. ${ }^{121}$ That is to say, there is a normative distinction within the criminal code between principalship and accomplice liability. In Germany, under StGB $\S 26$ the participant is held responsible for instigating the underlying offence; under StGB $\S 27$ the participant is held responsible for assisting the commission of the underlying offence. ${ }^{122}$ Accomplices are held responsible for complicity; the acts of their principals are not

\footnotetext{
${ }^{118}$ See Nigel Foster \& Satish Sule, German Legal System and Laws (4 $4^{\text {th }}$ ed., OUP 2010) 375. Instigating 'means to evoke another person's intent to commit an offence.'

${ }^{119} \mathrm{StGB} \S 27$.

${ }^{120}$ Foster \& Sule, German Legal System and Laws 376.

${ }^{121}$ Van Sliedregt, Individual Criminal Responsibility 70.

${ }^{122} \mathrm{StGB} \S 26 ; \mathrm{StGB} \S 27$.
} 
imputed to them. This is a conceptually coherent and normatively desirable approach to participation in wrongdoing.

\subsubsection{Different Stages of Differentiation}

To give a richer account of participation in wrongdoing, it is helpful to distinguish three kinds of differentiation:

A. Doctrinal differentiation;

B. Differentiation in responsibility;

C. Differentiation in the consequences of responsibility.

Doctrinal differentiation distinguishes among participants in wrongdoing at the level of legal doctrine. In the context of complicity, the law recognises the category of accomplice, and with it certain doctrinal requirements of conduct and fault. Differentiation in responsibility distinguishes among participants in wrongdoing at the stage of conviction or responsibility. An accomplice is not held responsible for the wrong of the principal but for her own contribution to that wrong. Differentiation in the consequences of responsibility distinguishes among participants at the sentencing or remedial stage of the process.

In criminal law, the principles of culpability and fair labelling require, ideally, differentiation amongst participants at each of the three stages. Where the subject of the rule is a state, the principle of sovereignty similarly demands differentiation at each of the three stages. In assessing the approach of various legal systems to the issue of differentiation, a lesson may be drawn from Anglo-American complicity law. Doctrinally, Anglo-American law does not follow a unitary model of participation in crime. The federal complicity rule in the United States speaks of aiders, abettors, 
counsellors, commanders, inducers, and procurers. ${ }^{123}$ In England and Wales, the Accessories and Abettors Act of 1861 refers to aiders, abettors, counsellors, and procurers. ${ }^{124}$ Thus judgments are littered with assessments in these terms. In other words, there is doctrinal differentiation among participants in crime. ${ }^{125}$

However, both the federal complicity rule in the US (18 USC $\S 2$ ) and the Accessories and Abettors Act in England and Wales are unitary at the level of responsibility and punishment. ${ }^{126} 18$ USC $\S 2$ makes an accomplice punishable as a principal. ${ }^{127}$ Although the provision refers only to punishment, it is rarely suggested that there is differentiation at the level of responsibility. ${ }^{128}$ Accomplices are not convicted of abetting murder or assisting a robbery, but of murder or robbery. ${ }^{129}$ This

12318 USC $\S 2$ (1994). See also Model Penal Code $§ 2.06(2)$ and (3) (Proposed Official Draft 1962):

(2) A person is legally accountable for the conduct of another person when:

(c) he is an accomplice of such other person in the commission of the offense.

(3) A person is an accomplice of another person in the commission of an offense if:

(a) with the purpose of promoting or facilitating the commission of the offense, he

(i) solicits such other person to commit it, or

(ii) aids or agrees or attempts to aid such other person in planning or committing it, or

(iii) having a legal duty to prevent the commission of the offense, fails to make proper effort so to do

${ }^{124}$ Accessories and Abettors Act, s. 8:

Whosoever shall aid, abet, counsel, or procure the commission of any indictable offence ... shall be liable to be tried, indicted, and punished as a principal offender.

${ }^{125} \mathrm{I}$ am grateful to Maris Köpcke Tinturé for discussion on this point.

${ }^{126}$ Van Sliedregt, Individual Criminal Responsibility 70-71.

${ }^{127} 18$ USC $\S 2$ (1994).

${ }^{128}$ See Weisberg 'Reappraising Complicity' 224: 'Thus, the modern view is that complicity is not a distinct crime, but a way of committing a crime.'; Dressler, 'Reforming Complicity Law' 433:

Despite the immense variations in participation suggested in the last paragraph, complicity law is binary: a person is or is not an accomplice. Legally speaking, there is no such thing as a "major" or "minor" accomplice. Thus, if the binary switch is turned on - the major or minor actor is deemed to be an accomplice- she and the perpetrator are treated alike in terms of guilt and potential punishment.' (footnote omitted).

${ }^{129}$ Dressler, 'Reassessing the Theoretical Underpinnings of Accomplice Liability' n.3. 
point is made more explicit in the American Law Institute's Model Penal Code.

Section 2.06 provides that an accomplice 'is legally accountable for the conduct of another person..., ${ }^{130}$ In England and Wales, the Accessories and Abettors Act renders accomplices liable to be indicted, tried, and punished as principals. ${ }^{131}$ Despite doctrinal differences between different forms of complicity, each leads to the same verdict - conviction of the principal's offence.

The lesson here is that we should look beyond the fact of doctrinal recognition of complicity to an appreciation of how the accomplice is held responsible and punished. In assessing different rules, we should also be aware that the same resultimputation of the conduct of a principal to an accomplice - may also be achieved through the definitional trick of including complicit conduct within the terms of the substantive offence. ${ }^{132}$ For instance, the West Virginia Code criminalises arson in the following manner:

Any person who willfully and maliciously sets fire to or burns, or who causes to be burned, or who aids, counsels, procures, persuades, incites, entices or solicits any person to burn, any dwelling, whether occupied, unoccupied or vacant, or any outbuilding, whether the property of himself or herself or of another, shall be guilty of arson in the first degree and, upon conviction thereof, be sentenced to the penitentiary for a definite term of imprisonment which is not less than two nor more than twenty years. 133

\footnotetext{
${ }^{130}$ Model Penal Code $\S 2.06(2)(\mathrm{c})$ (Proposed Official Draft 1962).

${ }^{131}$ Accessories and Abettors Act, s 8. See P.R. Glazebrook, 'Structuring the Criminal Code: Functional Approaches to Complicity, Incomplete Offences, and General Defences' in Andrew Simester and ATH Smith (eds), Harm and Culpability (Clarendon 1996) 195, 200:
}

The basic principle underlying the modern law of complicity is, thus, quite simply, that a person may commit an offence in one or other of two ways. He may do so either by doing what has been declared to be an offence or by helping or encouraging someone else to do that.'

${ }^{132}$ See Vogel, ‘Twelve Models’ 160-161.

${ }^{133}$ W. Va. Code § 61-3-1 (1977) cited in Paul Robinson 'Imputed Criminal Liability' (1984) 93 Yale

L. J. 609, n.6 (emphasis added). 
Evidently, the definition of the substantive offence does the work of imputation in respect of arson. The aider, the counsellor, the procurer, they are all responsible for the substantive offence of arson in the first degree. In this case, there is most likely overlap with the general complicity rule operating in West Virginia. ${ }^{134}$ Nonetheless, the rule demonstrates another way of achieving the same result: the responsibility of a participant for wrongdoing committed by the principal. ${ }^{135}$

Where a legal system differentiates between principals and accomplices at the level of the attribution of responsibility, it will ordinarily follow that the accomplice is punished for her own acts rather than for the acts of the principal. That is to say, there will ordinarily be differentiation in the consequences of responsibility. In criminal cases this does not mean that the tariff will not be set by reference to the principal's crime - it is, of course, more reprehensible to aid murder than to aid robbery. In Germany, aiders under StGB $\S 27$ receive at least a discount of $1 / 4$ vis-à-vis the principal. ${ }^{136}$ It also does not mean that certain accomplices will not be punished to the same extent as the principal. ${ }^{137}$ Those convicted as instigators under StGB $§ 26$ are liable to be sentenced as if they were principals.

\footnotetext{
${ }^{134}$ The orthodox approach to accomplice liability in West Virginia may be found in State $v$ Fortner, 182 W. Va. 345, 387 S.E.2d 812 (1989).

${ }^{135}$ See George Fletcher, Rethinking Criminal Law (first published 1978, OUP 2000) 649-650:
}

Aiding another person to commit a crime renders one an accomplice, and being an accomplice is simply one way of "being guilty of an offence." This way of approaching the problem of what the code calls "liability for conduct of another" is but a technique for rounding out the definition of particular offences. Every offence has built into it a penumbral orbit of liability for those who aid others in committing the offence.'

${ }^{136} \mathrm{StGB} \S 27,49(1)(2)$. See also Dubber 'Criminalizing Complicity' 984.

${ }^{137} \mathrm{StGB} \S 26$. 
More interesting are the practices of legal systems that use imputational complicity rules. Even if an accomplice is held responsible for murder rather than for complicity in murder, judicial discretion might enable an accomplice's lower degree of participation to be taken into account at the sentencing stage. ${ }^{138}$ The obvious temptation is to suggest that it does not matter that accomplices are held responsible as principals if differences in culpability can be reflected at sentencing. ${ }^{139}$ Such a suggestion is unwarranted. No doubt variations in sentencing do denote important assessments regarding the culpability of participants in crime. However, where the accomplice is actually convicted of the principal's crime, sentence variations at best mitigate the violation of the principles of culpability and fair labelling. The accomplice is still held responsible for murder and labeled as a murderer.

The question of sentencing is linked to another point. The principled concerns about culpability and fair labelling are sometimes obscured by arguments about the relative blameworthiness of accomplices and principals. Generally, those who assist or encourage wrongdoing are less culpable that those who commit it. ${ }^{140}$ Of course, as we move up the scale of psychological influence from encouragement, to instigation, to procurement, to ordering, the picture becomes cloudier. ${ }^{141}$ In part, by capturing within principalship those who control the commission of the offence, a normative

\footnotetext{
${ }^{138}$ See Fletcher, Rethinking Criminal Law 636-637.

${ }^{139}$ See James Stewart, ‘The End of “Modes of Liability” for International Crimes' (2012) 25 Leiden J. Intl L. 165, 171:

I argue that whatever moral significance there might be between making a difference to a crime and 'making a difference to the difference that principals make', this discrepancy can be adequately accounted for at the sentencing stage of a criminal trial. (footnote omitted).

${ }^{140}$ Ashworth, Principles of Criminal Law 406.

${ }^{141}$ This issue sometimes throws up what might be called the Hitler-as-accomplice problem. See Osiel, 'Making Sense of Atrocity' 85; Stewart, 'The End of Modes of Liability' 166-167. This problem, to the extent it is a problem, may be resolved in a number of ways, including by the adoption of a normative model of perpetration or through the use of ordering as a heightened mode of participation.
} 
model of perpetration addresses these concerns. But more importantly, even if there are situations in which an instigator or facilitator is as blameworthy as (or more blameworthy than) the principal, she still did not commit the wrong. ${ }^{142}$ The principles of culpability and fair labelling require that instigators and facilitators are held responsible and punished for instigation and facilitation. Increased blameworthiness vis-à-vis the principal may be expressed at sentencing.

In sum, then, there are two points here. First, we should not let doctrinal differentiation of participation in wrongdoing blind us to what is happening at the level of responsibility and punishment. Secondly, differentiation in the consequences of responsibility, often obtained through judicial discretion, mitigates but does not obviate principled concerns about holding an accomplice responsible for a wrong she did not commit. In Austin's term, the pronouncement of the court is a verdictive; it is an official judgment, in this case concerning responsibility. ${ }^{143}$ Where accomplices are held responsible as though they committed the wrong, there is verdictive congruence where there ought to be none. A principled scheme of participation in wrongdoing would hold accomplices responsible for, and label them in terms of, their own contribution to the principal's wrong.

\subsubsection{Substantive Complicity Rules}

The discussion up to this point on structuring complicity rules has assessed complicity as it is accounted for in the general part of the criminal law. In this context, there are principled reasons for preferring differentiation between principals and accomplices at the level of attribution of responsibility. Another way to reach the same result is

\footnotetext{
${ }^{142}$ I am grateful to Doug Husak for discussion on this point.

${ }^{143}$ JL Austin, How to Do Things with Words (OUP 1962) 150.
} 
through substantive complicity rules. Rules of this kind sanction complicity as its own substantive wrong. ${ }^{144}$ Some scholars implicitly assume that these rules are not a form of complicity because there is no imputation of the conduct of the principal to the accomplice. ${ }^{145}$ This assumption is unfounded. Although the prevailing approach to complicity in some systems is imputational, other forms of derivative liability that hold actors responsible for helping or influencing another actor to commit wrongdoing are still complicity rules. Although complicity rules are always derivative, they are not always imputational.

In the US, concerns with imputational criminal complicity have provoked tentative moves towards the substantive complicity model. An example may be found in New York State's facilitation laws. ${ }^{146}$ Facilitation, rather than denoting a form of assistance for the purposes of imputational complicity liability, constitutes a criminal offence per se. The New York Penal Law creates four degrees of the offence of criminal facilitation. ${ }^{147}$ Criminal facilitation in the second degree is illustrative of the statute's approach:

A person is guilty of criminal facilitation in the second degree when, believing it probable that he is rendering aid to a person who intends to commit a class A felony, he engages in conduct which provides such person with means or opportunity for the commission thereof and which in fact aids such person to commit such class A felony.

Criminal facilitation in the second degree is a class C felony. ${ }^{148}$

\footnotetext{
${ }^{144}$ See Vogel, 'Twelve Models’ 160-161.

${ }^{145}$ See e.g. Dubber, 'Criminalizing Complicity’ 993.

${ }^{146}$ Weisberg 'Reappraising Complicity' 261.

${ }^{147}$ New York Penal Law § 115.

${ }^{148}$ New York Penal Law $\S 115.05$.
} 
This is a substantive complicity rule. Criminal facilitation rules of this kind avoid both the problem of exclusively inchoate offences ${ }^{149}$ and the principled objections to imputational complicity. ${ }^{150}$ In respect of the former, they impose sanction that responds to the additional wrongdoing arising when the harm occurs. ${ }^{151}$ In respect of the latter, the facilitator is held responsible only for his own acts and is punished in line with his own culpability.

New York State's compromise facilitation laws hint at another advantage accruing to non-imputational complicity rules. The use of complicity as an imputational doctrine denies any normative difference between different modes of complicity. Aiders, counsellors, encouragers, and facilitators are all responsible for the principal's wrong. Imputation prevents distinctions from being drawn not only between principals and accomplices but also among different kinds of accomplices, at least at the stage of the attribution of responsibility. For instance, those who incite or induce another to commit crime may bear greater responsibility than those who simply advise on, say, the possibilities of escape. ${ }^{152}$ The German Criminal Code recognises this distinction by refusing to allow to instigators the sentencing discount available to facilitators. ${ }^{153}$ Other differences among modes of complicity are imaginable. This point is taken up in Section 2.5.2 below.

\footnotetext{
${ }^{149}$ See Ch 2.4 .4 below.

${ }^{150}$ See Ch. 2.4.1 above.

${ }^{151}$ The legal system may or may not proscribe failed attempts at complicity on top of substantive complicity rules. In England and Wales, inchoate crimes of assisting or encouraging crime were introduced by sections 44-46 of the Serious Crime Act 2007. See Andrew Simester et al, Simester and Sullivan's Criminal Law: Theory and Doctrine ( $4^{\text {th }}$ ed., Hart 2010) 253-254; Fletcher, Rethinking Criminal Law 680-681.

${ }^{152}$ See Fletcher, Rethinking Criminal Law 671-672.

${ }^{153} \mathrm{StGB} \S 26$; StGB $\S 27$.
} 
Substantive complicity rules open up the possibility of drawing distinctions in terms of both the forms of complicity prohibited and the wrongdoing committed by the principal actor. ${ }^{154}$ Many jurisdictions have created a substantive offence of assisting the escape of a prisoner. ${ }^{155}$ For instance, Section 575.230 of the Missouri Revised Statutes provides that aiding the escape of a prisoner being held on a felony charge or conviction is itself a class B felony. ${ }^{156}$ Of course, the escape is itself a crime for which the prisoner is liable. ${ }^{157}$ However, the aider is responsible for his own actions. Here we see the prohibition of a general form of complicity - aidingin a specific crime.

A rule might be specific at both the level of the complicit conduct and in terms of the assisted wrong. In international law, the rule reflected in Article 3(f) of the Definition of Aggression prohibits states from allowing their territory to be used by another state to commit an act of aggression against a third state. ${ }^{158}$ The rule does not prohibit states from aiding acts of aggression in ways other than the provision of

\footnotetext{
${ }^{154}$ Weisberg 'Reappraising Complicity' 264.

${ }^{155}$ Offences of this kind may have been introduced to remedy (incorrectly) perceived difficulties arising on the basis that the status of the principal - in this case, a prisoner-meant that others could not be complicit in his crime. Although a non-prisoner cannot commit the crime of escaping from prison, it is not the case that a non-prisoner cannot contribute to - that is, be complicit in-such an escape. See Kadish, 'Complicity, Cause and Blame' 372-374.
}

${ }^{156}$ Mo. Rev. Stat. § 575.230.1:

A person commits the crime of aiding escape of a prisoner if the person:

(2) Assists or attempts to assist any prisoner who is being held in custody or confinement for the purpose of effecting the prisoner's escape from custody or confinement.

See also Weisberg, 'Reappraising Complicity' 221. It should be noted it is ordinarily specified that the substantive offence of aiding in the escape of a prisoner may be committed whether or not the escape occurs. Where the escape does not occur, the substantive crime of aiding is not a true example of derivative liability, and thus of complicity. This example serves only to illustrate how substantive complicity rules allow us to draw distinctions in terms of both the kinds of assistance rendered and the nature of the principal's wrong.

${ }^{157}$ Mo. Rev. Stat. $§ 575.210$.

${ }^{158}$ UNGA Res 3314 (XXIX) (14 December 1974) (Definition of Aggression). 
territory. Likewise, it does not prohibit states from allowing their territory to be used in the commission of any internationally wrongful act other than aggression. It prohibits a specific kind of complicit conduct in a specific wrong.

So there are two ways that a legal system may prohibit complicity without imputing the conduct of the principal to the accomplice. The first, ordinarily found in the general part of the criminal law, uses a model of participation in wrongdoing that distinguishes amongst participants at the level of the attribution of responsibility. The second uses specific substantive complicity rules. Both may be termed nonimputational complicity. In each case, accomplices are held responsible in terms of their own fault and conduct; that is to say, for their contribution to the principal's wrong. In contrast to imputational complicity rules, both approaches reflect in law that complicity is a particular mode of wrongdoing.

\subsubsection{Inchoate Liability: Getting Rid of Complicity?}

So far, this chapter has set out a definition of complicity, assessed the wrongness of complicity, and considered the ways in which complicity rules may be structured, the last-mentioned giving rise to a preference for non-imputational complicity. Before setting out the analytical framework of the thesis, it is important to consider a challenge to complicity emanating from another direction. This challenge proposes a shift away from complicity as a derivative form of responsibility, instead establishing inchoate wrongs of assisting and encouraging wrongdoing. ${ }^{159}$ Under such a scheme, the responsibility of the complicit actor is founded in law at the moment she performs

\footnotetext{
${ }^{159}$ See Law Commission, Assisting and Encouraging Crime (Law Com CP No 131, 1993).
} 
her culpable acts of assistance or encouragement. ${ }^{160}$ In England and Wales, this shift was evident in the development of the common law offence of incitement.

Incitement, in this context, is essentially synonymous with encouragement. ${ }^{161}$ The inciter's liability is fixed at the moment of incitement, regardless of whether the incited party perpetrates the crime.

Crucially, under such a scheme it does not matter for the purposes of the participant's responsibility whether or not the wrong is committed. ${ }^{162}$ Responsibility is entirely inchoate rather than derivative. A shift towards inchoate responsibility of this kind would signal the end of complicity as a legal doctrine.

There is a principled attraction to this view. In the majority of cases, once the complicit actor has performed her acts of assistance or encouragement with the requisite culpability, the occurrence of the harm is outside of her control. It is an instance of moral luck. ${ }^{163}$ Consider these examples:

$\mathrm{D}$, knowing that $\mathrm{P}$ intends to burgle $\mathrm{V}$ 's premises, leaves a ladder outside V's house in order to assist $\mathrm{P}$ to enter the premises. On learning that $\mathrm{V}$ has returned from holiday earlier than expected, $\mathrm{P}$ abandons the project.

$\mathrm{D}$, knowing that $\mathrm{P}$ intends to burgle $\mathrm{V}$ 's premises, leaves a ladder outside V's house to assist $\mathrm{P}$ to enter the premises. $\mathrm{P}$, unaware that $\mathrm{D}$ has left the ladder, commits the burglary without using the ladder.

$\mathrm{D}$, knowing that $\mathrm{P}$ intends to burgle V's premises, leaves a ladder outside V's house to assist $\mathrm{P}$ to enter the premises. P uses the ladder to commit the burglary. ${ }^{164}$

\footnotetext{
${ }^{160}$ Ibid [4.24].

${ }^{161}$ Law Com No 300 [3.19]; Marlow [1998] 1 Cr. App. R. (S.) 273, 275.

${ }^{162}$ In this sense, it is analogous to the obligation of non-refoulement in international lawresponsibility is not contingent on subsequent wrongdoing by the recipient state.

${ }^{163}$ Andrew Ashworth, 'Belief, Intent, and Criminal Liability' in John Eekelaar and John Bell (eds), Oxford Essays in Jurisprudence - Third Series (Clarendon 1987) 1, 16-20.

${ }^{164}$ See Law Com No 300 [3.2]-[3.5].
} 
In the first example, the burglary is not committed. In the second, the burglary is committed without D's assistance. In the final example, D successfully assists in the commission of the offence. If we think the defendant in the final example should be treated equivalently to the first two then a system of inchoate responsibility should be adopted.

This issue forms part of a larger philosophical debate concerning the roles of harm and moral luck in assessing the gravity of wrongdoing, a debate prominent in the theory of liability for attempts in criminal law. Criminal liability is ordinarily based on (i) the harm caused and (ii) the culpability of the perpetrator. ${ }^{165}$ The classic example in attempts liability concerns two actors, both of whom intend to kill their victim by shooting. ${ }^{166}$ In the first case, the victim is hit and dies. In the second case, the bullet misses. Subjectivist theorists advance a thesis that the moral position of the two shooters is no different. ${ }^{167}$ Taken a step further, judgments as to their culpability, and thus as to criminal responsibility and punishment, should be alike. ${ }^{168}$

Although alluring, the subjectivist thesis is not entirely convincing. One objection focuses on the expressive goals of the criminal law. For the law to embrace the subjectivists' moral equivalence thesis is for it to say that it does not matter to the law whether or not the harm results. ${ }^{169}$ But harm should matter to the perpetrator, to

\footnotetext{
${ }^{165}$ Ashworth, Principles of Criminal Law 438; J.C. Smith, 'Some Problems of the Reform of the Law of Offences against the Person' (1978) 31 CLP 15; Ashworth, 'Belief, Intent, and Criminal Liability' 4.

${ }^{166}$ Ashworth, 'Belief, Intent, and Criminal Liability' 16.

${ }^{167}$ Ibid.

${ }^{168}$ See Antony Duff, Criminal Attempts (OUP 1996) 335.

${ }^{169}$ Antony Duff, Intention, Agency and Criminal Liability - Philosophy of Action and the Criminal Law (Blackwell 1990) 191.
} 
the law, and to us. ${ }^{170}$ Strictly speaking, this objection is more accurately located in the realm of legal theory than moral theory, for its solution is grounded explicitly in the role of the criminal law. ${ }^{171}$ At the level of moral theory, however, the equivalence thesis is also open to challenge. Luck does rightly influence judgments about morality. As Nagel puts it:

Whether we succeed or fail in what we try to do nearly always depends to some extent on factors beyond our control. This is true of murder, altruism, revolution, the sacrifice of certain interests for the sake of others - almost any morally important act. What has been done, and what is morally judged, is partly determined by external factors... $[\mathrm{T}]$ here is a morally significant difference between reckless driving and manslaughter. But whether a reckless driver hits a pedestrian depends on the presence of the pedestrian at the point where he recklessly passes a red light. ${ }^{172}$

In other words, consequences matter. Accounting for the harm (and good) we bring about is an essential part of morality, responding to our capacity as causal agents. Nagel's moral point is generally upheld in contemporary assessments of the gravity of offences. ${ }^{173}$ In the context of criminal attempts, it is right that we hold the murderer more blameworthy than the attempted murderer, even though it may be a matter of luck that one is not the other, or vice versa. So it should be in complicity. Successful attempts at assistance or encouragement are more reprehensible than unsuccessful attempts. A system of inchoate liability that treats the two alike does not accurately reflect the increased culpability of those who successfully help or influence principal wrongdoers.

\footnotetext{
${ }^{170}$ Ibid.

${ }^{171}$ Andrew Ashworth, 'Taking the Consequences' in Stephen Shute, John Gardner and Jeremy Horder (eds), Action and Value in Criminal Law (Clarendon 1993) 107, 113.

172 Thomas Nagel, Mortal Questions (CUP 1979) 25.

${ }^{173}$ See Paul Robinson and John Darley, 'Objectivist v. Subjectivist Views of Criminality: A Study in the Role of Social Science in Criminal Law Theory’ (1998) 18 OJLS 409.
} 


\subsubsection{Conclusion}

Complicity is a particular mode of wrongdoing. In reflecting this, legal systems should hold accomplices responsible for their own contribution to the principal's wrong, rather than for the wrong of their principal. This is the normative claim of the thesis. In this form, complicity avoids the principled objections to imputational responsibility as well as the inadequate attention to consequences inherent in an inchoate model of responsibility. This normative claim is used to evaluate the ways in which international law prohibits state and individual complicity.

\subsection{Prohibiting COMPLicity: An ANALYTICAL Framework}

\subsubsection{Introduction}

The argument thus far has sought to establish the normative claim of the thesis; namely, that doctrines of complicity ought to give rise to responsibility and sanction for the accomplice's contribution to the principal's wrong. It is against this standard that the complicity rules binding states and individuals in international law are measured below.

Any attempt to prohibit complicit conduct must resolve three issues. The first concerns the forms of complicity prohibited. Between and within the categories of help and influence, legal systems take different approaches. It is conceivable that one legal system prohibits only physical help and another only psychological influence. Moreover, within the category of influence, certain modes of complicity may be specifically incorporated or rejected. This issue relates to the second question - the required nexus between the assistance or influence provided and the principal's wrong. Ought there to be a substantiality criterion limiting the reach of accomplice 
liability? The third question concerns the fault of the complicit party. What forms of fault are appropriate for complicity?

In Parts $\mathrm{B}$ and $\mathrm{C}$ of the thesis, attention will be paid to the nature of the legal subject bound by the rule. The appropriate forms of conduct and culpability constituting complicity might vary according to the subject's status as a state or individual. In addition, each of the three elements of the rule is inter-dependent; the appropriate nexus criterion may depend on the forms of conduct sanctioned, which in turn may depend on the fault required of the accomplice. The rest of this section constructs a framework around these three issues, using domestic criminal law and criminal law theory to give context and colour to the questions that arise in Parts B and C. This framework allows an analytical discussion of complicity in international law.

\subsubsection{Issue One: Forms of Complicity}

\subsubsection{Helping and Influencing}

As noted above, the terms used in criminal law to prohibit complicity are numerousaiding, abetting, assisting, facilitating, inciting, inducing, soliciting, encouraging, instigating, and so on. Each of these denotes a form of complicity, some of which overlap, at times entirely. The challenge for the law is to draw principled lines and establish workable doctrine. In terms of the principle of fair labelling, categories of wrongdoing should be differentiated to reflect morally significant differences in 
blameworthiness. ${ }^{174}$ In addition, as Ashworth puts it, 'where people generally regard two types of conduct as different, the law should try to reflect that difference., ${ }^{175}$

As a starting point, Kadish's division of complicity into cases of help and cases of influence is useful. ${ }^{176}$ Of course, the distinction is not watertight. Although acts that influence the decision of the perpetrator to commit the wrong cannot also be considered acts of help, the converse is not true. ${ }^{177}$ Fletcher gives the example of a German case where the accomplice provided a key to the principal to facilitate his theft of wine from a cellar. ${ }^{178}$ The key did not fit the lock so the principal broke into the cellar. ${ }^{179}$ Nonetheless, it is easy to view the provision of the key — the help - as an act that influences the decision of the principal to commit the wrong.

Despite the overlap, a general division between help and influence makes sense. In criminal law, the doctrines of aiding and abetting are sometimes thought to map onto this distinction. ${ }^{180}$ However, the gravity of different kinds of conduct falling within a single category of psychological influence is too wide-ranging. Compare these two scenarios:

A. A local drug dealer, A1, is owed money by P1. P1 is broke. A1 tells $\mathrm{P} 1$ that if he beats up $\mathrm{V}$ the debt will be forgiven. $\mathrm{P}$ beats up $\mathrm{V}$.

B. A2 sees P2 beating up V. He shouts encouragement to P2 from across the street. P2 continues to beat up V.

\footnotetext{
${ }^{174}$ Ashworth, Principles of Criminal Law 78.

${ }^{175}$ Ibid 79.

${ }^{176}$ Kadish, 'Complicity, Cause and Blame' 342. See also Smith, A Treatise on Complicity 33.

${ }^{177}$ See Dressler, 'Reforming Complicity Law' 22.

${ }^{178}$ Fletcher, Rethinking Criminal Law 677-678.

${ }^{179}$ Ibid.

${ }^{180}$ See Mrkšić, Radić, Šljivančanin (Trial Chamber Judgment) IT-95-13/1-T (27 September 2007)

[551]; William A. Schabas, The International Criminal Court - A Commentary on the Rome Statute (OUP 2010) 434; Eser, 'Individual Criminal Responsibility’ 799.
} 
Both A1 and A2 were complicit in the assault but there is a morally significant difference in their culpability. ${ }^{181}$ So far as possible, the law should recognise this difference. In this regard, the scheme envisaged in Article 25(3) of the Rome Statute of the International Criminal Court, for instance, makes sense. ${ }^{182}$ Article 25(3) distinguishes between inducing and soliciting, on one hand, and abetment, on the other, as forms of influence on the decision of the perpetrator to commit the crime. ${ }^{183}$ Inducing and soliciting wrongdoing may be regarded as synonymous with instigation. Abetment may be regarded as synonymous with encouragement. Once we divide cases of influence into instigation and encouragement, the respective label conveys, more or less, the degree of blameworthiness of the instigator or encourager. ${ }^{184}$ of course, there will still be some context-specific variance of culpability within each category, turning on the position of the accomplice, the relationship between the accomplice and the principal, and the force of the instigation or encouragement. But for the most part, the label gives a decent description of the wrongfulness of the accomplice's conduct.

The category of help or assistance presents a trickier challenge for the principle of fair labelling. Husak argues that 'almost no one would be inclined to use generalizations such as “"Bill aided a crime” ... or "Howard helped Elizabeth commit a murder." 185 Moreover, there may be normatively significant differences between

\footnotetext{
${ }^{181}$ I am grateful to John Gardner for discussion on this point.

${ }^{182}$ Rome Statute of the International Criminal Court (adopted 17 July 1998, entered into force 1 July 2002) 2187 UNTS 90.

${ }^{183}$ Art 25 Rome Statute.

${ }^{184}$ See HLA Hart and Tony Honoré, Causation and the Law ( $2^{\text {nd }}$ ed., Clarendon 1985) 378.

${ }^{185}$ See Doug Husak, 'Abetting Crime' (forthcoming).
} 
driving a getaway car, holding a ladder, providing a gun, and failing to lock a door. ${ }^{186}$ If this is so, we may want these differences reflected in labelling. ${ }^{187}$

One solution may lie in the regulation of specific kinds of complicit conduct within the category of assistance. There is a potential red herring here. The required specialisation does not (only) refer to the crime aided, but to the kind of complicit conduct. In other words, this challenge is not met by defining a specific crime of aiding in the escape of a prisoner. The law would need to differentiate among normatively different forms of aiding — perhaps financing, providing weapons, knowing failure to prevent in breach of a specific duty, and so on. There are risks here, though. The aforementioned kinds of complicit conduct are themselves liable for further sub-division, and they do not nearly account for the myriad ways we may assist another actor's commission of wrongdoing. ${ }^{188}$ In addition, there are issues of over-complexity and accessibility in moving towards an ever more refined and differentiated code. ${ }^{189}$

This problem requires further work. One solution would be to draw from the general barrel of assistance certain particularly culpable or easily differentiated kinds of complicit conduct. The proliferation of materials concerning financing of terrorism is a step in this direction. ${ }^{190}$ In international law, an interesting example is again the rule reflected in Article 3(f) of the Definition of Aggression: the obligation imposed

\footnotetext{
${ }^{186}$ Ibid.

${ }^{187}$ Ashworth, Principles of Criminal Law 78.

${ }^{188}$ Christopher Kutz, 'Causeless Complicity' (2007) 1 Crim. L. \& Phil. 289, 294.

${ }^{189}$ See Ashworth, Principles of Criminal Law 80-81; Chalmers and Leverick, 'Fair Labelling in Criminal Law' 23-28. See also Jeremy Horder, 'Rethinking Non-Fatal Offences against the Person' (1994) 14 OJLS 335, 339 for a framing of labelling as falling between particularism and moral vacuity.

${ }^{190}$ See Doug Husak, 'Abetting Crime’ (forthcoming).
} 
on states not to allow their territory to be used by another state for an act of aggression. ${ }^{191}$ Here we see a prohibition of a very specific kind of complicit conduct.

Despite these difficulties, it remains useful to divide up complicity into two categories of influence - instigation and encouragement — and one form of assistance. A legal system may use a combination of these terms or their synonyms to prohibit complicity. It may prohibit one without the others or divide them further. At the top end of the culpability spectrum, forms of influence and assistance that cross into principalship are excluded from complicity. Assuming a normative model of perpetration, it is appropriate to assign principal responsibility to some secondary parties who do not physically do the deed. ${ }^{192}$ This category includes at least those who order the commission of wrongdoing, those who use another as an innocent instrumentality, and those who are in an agency relationship with the physical perpetrator. ${ }^{193}$ Given the scalar quality of influence and assistance, there are no doubt difficult boundary decisions to be made. ${ }^{194}$ But neither these boundary difficulties nor the challenge of labelling discussed above detracts from the broader normative claim of the thesis: the accomplice should not be held responsible for the principal's wrong.

\subsubsection{Complicity and Omissions}

\subsection{Introduction}

One recurring issue about the kinds of conduct that constitute complicity concerns omissions. Given the range of preventive duties imposed on states, this issue

\footnotetext{
${ }^{191}$ Art 3(f) Definition of Aggression.

${ }^{192}$ See Ch. 2.4.1 above.

${ }^{193}$ See Doug Husak, 'Abetting Crime' (forthcoming).

${ }^{194}$ Ibid.
} 
resonates in international law and state responsibility. ${ }^{195}$ In addition, international criminal law is slowly coming to terms with omissions that help or encourage others to commit crimes. ${ }^{196}$

The central question is whether a failure to act may fulfill the conduct element of a particular rule of complicity. It is not controversial that an omission may be prohibited by a specific rule, the breach of which gives rise to direct liability. ${ }^{197}$ In national legal systems, these offences are often statutory. ${ }^{198}$ For instance, under the United Kingdom's Merchant Shipping Act of 1995, it is an offence for the master of a ship, on receiving at sea a signal of distress, to fail to assist an aircraft. ${ }^{199}$ In international law, Article 85(4)(b) of Additional Protocol I to the Geneva Conventions requires the contracting parties to repatriate prisoners of war and civilians without unjustifiable delay, with the effect that failure to repatriate in good time engages the international responsibility of the state. ${ }^{200}$

These examples of direct responsibility are of less interest. More relevant are instances in which the omission might link the omitting party to the harm that

\footnotetext{
${ }^{195}$ See e.g. Art 2(1) Convention against Torture; Art I Convention on the Prevention and Punishment of the Crime of Genocide Convention (adopted 9 December 1948, entered into force 12 January 1951) 78 UNTS 277.

${ }^{196}$ See Ch. 5.2 below; Mrkšić, Šljivančanin (Appeals Chamber Judgment) IT-95-13/1A (5 May 2009).

${ }^{197}$ Fletcher, Rethinking Criminal Law 422; Michael Duttwiler, 'Liability for Omission in International Criminal Law' (2006) 6 Intl Crim. L. Rev. 1, 7-8.

${ }^{198}$ Fletcher, Rethinking Criminal Law 422. See generally Andrew Ashworth, 'The Scope of Criminal Liability for Omissions' (1989) 105 LQR 424.

${ }^{199}$ Merchant Shipping Act 1995, s 93. See Brian Hogan, 'Omissions and the Duty Myth' in Peter Smith (ed.), Criminal Law: Essays in Honour of JC Smith (Butterworths 1987) 85, 86.

${ }^{200}$ Art 85(4)(b) Protocol Additional to the Geneva Conventions of 12 August 1949, and relating to the Protection of Victims of International Armed Conflicts (adopted 8 June 1977, entered into force 7 December 1978) 1125 UNTS 3. See Duttwiler, 'Liability for Omission’ 7-8.
} 
results. ${ }^{201}$ In criminal law, this may arise through principal omissions liability or accomplice omissions liability. In terms of principal liability, omissions may be a way of perpetrating the substantive offence. If, for instance, a parent allows his child to starve to death, this approach would categorise such conduct as murder. ${ }^{202}$ This may be referred to as a prohibition on 'commission by omission', ${ }^{203}$ and contrasted with direct criminalisation of an omission - in this case, perhaps, intentional neglect of a child. In terms of accomplice liability, an omission is a way in which the conduct element of complicity liability may be fulfilled. This may be thought of as commission of aiding and abetting by omission. Liability of this kind is underpinned by the same idea as commission by omission — an omission can be as wrongful as an act or, if not equally wrongful, sufficiently wrongful to justify criminal liability as though an act was committed. ${ }^{204}$

\subsection{A Municipal Criminal Law Approach to Omissions}

In criminal law, liability for a complicit omission is rare. In England and Wales, complicity through omission has most often arisen in the context of ownership or control of a vehicle or premises. $^{205}$ In Rubie v Faulkner, for instance, a learner-driver was driving under the defendant's supervision in accordance with the Motor Vehicles (Driving Licenses) Regulations, $1937 .^{206}$ The driver caused an accident and was convicted of driving without due care and attention. The defendant, who had sat

\footnotetext{
${ }^{201}$ See Fletcher, Rethinking Criminal Law 423: "The gravamen of liability for "breach of duty" is the breach itself; for commission by omission, the occurrence of a particular result.'

${ }^{202}$ See Ashworth, Principles of Criminal Law 98-99.

${ }^{203}$ Fletcher, Rethinking Criminal Law 422; Duttwiler, 'Liability for Omission' 5.

${ }^{204}$ Duttwiler, 'Liability for Omission' 5; Sanford Kadish, 'Act and Omission, Mens Rea, and Complicity: Approaches to Codification’ (1989) 1 Crim. L. Forum 65, 70.

${ }^{205}$ Smith, A Treatise on Complicity 40.

${ }^{206}$ [1940] 1 KB 571.
} 
passively in the front seat while the driver undertook a dangerous passing maneuver, was convicted at first instance of aiding and abetting by omission. The conviction was upheld on appeal on the basis of his failure to act in accordance with the duty imposed by the regulations. ${ }^{207}$ This approach has been applied in other cases of supervision of learner-drivers. ${ }^{208}$

The principle has also arisen in respect of motor vehicle owners who fail to intervene to prevent a principal from driving dangerously in their car $^{209}$ and licensees who fail to shut a public house as required, thereby aiding and abetting the consumption of intoxicating liquor outside of permitted hours. ${ }^{210}$ Critically, in these cases the defendant was not under a duty to act but rather had a power of control. ${ }^{211}$ Although there is some suggestion in other judgments that the defendant's complicity is founded on the encouragement that the principal receives from her inaction, ${ }^{212}$ the better interpretation is that the failure to act where there is a power of control constitutes accomplice liability. ${ }^{213}$ The extension of liability to situations of control over property is incoherent with the general structure of criminal omissions liability, which turns on the existence of a duty to act, rather than as an incident of property ownership. $^{214}$

\footnotetext{
${ }^{207}$ Ibid 574.

${ }^{208}$ See Harris [1964] Crim. LR 54; Crampton v Fish [1969] 113 S.J. 1003. See also Smith, A Treatise on Complicity 41.

${ }^{209}$ Du Cros v Lambourne [1907] 1 KB 40; $R v$ Webster [2006] EWCA Crim 415.

${ }^{210}$ Tuck v Robson [1970] 1 All ER 1171.

${ }^{211}$ Ashworth, Principles of Criminal Law 411; Smith, A Treatise on Complicity 42-43.

${ }^{212}$ See e.g. Cassady v Reg Morris (Transport) Ltd [1975] RTR 470.

${ }^{213}$ Smith, A Treatise on Complicity 42.

${ }^{214}$ Ashworth, 'Criminal Liability for Omissions' 446.
} 
Although the underlying theoretical bases of principal and accomplice liability are not the same, ${ }^{215}$ in the absence of cases or scholarship on complicit omissions it makes sense to look to principal omissions liability. The key to understanding cases of commission by omission is the presence of a specific legal duty to prevent harm. ${ }^{216}$ It is sufficient to sketch the common categories of duty. First, the duty may arise on the basis of the relationship between the defendant and person suffering the harm. The relationship is usually one between parent and child or between spouses. ${ }^{217}$ Second, duties, often statutory, may be imposed on the basis of the defendant's status. These are usually obligations of the kind imposed on doctors, nurses, and other professionals. Third, duties sufficient to give rise to criminal responsibility may be imposed on people who have a special relationship to the particular harm that arises. $^{218}$ The case of Miller is an apt illustration. ${ }^{219}$ The defendant fell asleep with a lit cigarette. He awoke, and seeing the bed alight, simply moved to another room. The house caught fire. Miller's conviction for arson was upheld on the basis that he failed to take steps to avert the harm caused by his prior dangerous act. ${ }^{220}$

Finally, the duty may arise from the assumption of a specific responsibility or undertaking to act in a specific way. ${ }^{221}$ In Pittwood, the defendant was employed by a railway company to control the gate at a crossing. ${ }^{222}$ After he failed to do so a train

\footnotetext{
${ }^{215}$ Smith, A Treatise on Complicity 43-44.

${ }^{216}$ Fletcher, Rethinking Criminal Law 611.

${ }^{217}$ Ibid 612; Simester et al, Simester and Sullivan's Criminal Law 71.

${ }^{218}$ Simester et al, Simester and Sullivan's Criminal Law 74-75.

${ }^{219}$ Miller [1983] 2 AC 161.

${ }^{220}$ Ibid. See Ashworth, 'Criminal Liability for Omissions' 439.

${ }^{221}$ Fletcher, Rethinking Criminal Law 614-618; Simester et al, Simester and Sullivan's Criminal Law 73-74.

${ }^{222}$ Pittwood [1902] 19 TLR 37.
} 
struck a cart that was crossing the tracks, killing the victim. Pittwood was convicted of manslaughter. The exact source of the duty in Pittwood is not clear. ${ }^{223}$ One possibility is that the source is the contract of employment itself. ${ }^{224}$ On this interpretation, the contract imposed a duty to act on the defendant, which duty was owed to the general public as third party beneficiaries. A second interpretation is that in cases of this kind, the undertaking to avert harm to someone or a class of people is an independent ground for imposing a duty of care. ${ }^{225}$ In many cases, these two duties will arise together, and determining the exact source of the duty for the imposition of criminal responsibility will not matter. ${ }^{226}$ For instance, a nurse may conclude a contract and undertake to care for a patient in her home. ${ }^{227}$ If she fails to care for the patient, there is little doubt that a breach of contract arises. She will also have breached her undertaking to care for the patient. Whether the imposition of criminal liability is based on the contractual duty or the undertaking will not matter.

In other cases, however, determining the source of the duty might matter. As Fletcher puts it, in deciding whether the omission was sufficiently culpable for criminal liability 'it would hardly be helpful to get entangled in the intricacies of consideration and contractual validity. ${ }^{228}$ There might be difficult questions of third party reliance — say, for instance, where a drowning swimmer did not know that a lifeguard was hired for his protection — that do not necessarily affect any assessment

\footnotetext{
${ }^{223}$ Simester et al, Simester and Sullivan's Criminal Law 73.

${ }^{224}$ See Pittwood [38].

${ }^{225}$ Fletcher, Rethinking Criminal Law 615.

${ }^{226}$ Ibid.

${ }^{227}$ See $R v$ Instan [1893] 1 QB 450.

${ }^{228}$ Fletcher, Rethinking Criminal Law 615.
} 
of moral culpability. ${ }^{229}$ A focus on the undertaking given by the defendant may remove some the vagaries of contract law and provide a more coherent basis for the imposition of omissions liability. Nonetheless, in the vast majority of cases the contract will still be the primary source in determining the existence and content of the duty.

In each case, the defendant's capacity to have averted the harm is a required element of criminal liability. This is consistent with a basic principle of fairness. ${ }^{230}$ Capacity also establishes that the omission was a factual cause of the harm-but for the failure to act the harm would not have resulted. ${ }^{231}$ In this sense, capacity might relate to the ability of the defendant herself to have intervened. If a parent saw her child drowning but was unable to swim herself, no liability would arise for failing to dive in. Alternatively, capacity might relate more specifically to the underlying event. In Morby, for instance, the defendant failed to obtain medical treatment for his sick son because of his religious beliefs. ${ }^{232}$ On appeal, his conviction was quashed on the basis that it was not shown that any such intervention would or would probably have prolonged the child's life. ${ }^{233}$ In a drowning case, the same principle applies - liability

\footnotetext{
${ }^{229}$ See Larry Alexander, 'Criminal Liability for Omissions: An Inventory of Issues' in Stephen Shute and Andrew Simester (eds), Criminal Law Theory: Doctrines of the General Part (OUP 2002) 121, 137-138.

${ }^{230}$ Ashworth, 'Criminal Liability for Omissions' 449-450.

${ }^{231}$ Simester et al, Simester and Sullivan's Criminal Law 104; Andrew Ashworth, Principles of Criminal Law 111. The essence of this point holds on alternative explanations of the role of causation in omissions cases. For instance, in Moore's view, omissions liability in duty cases is non-causal. Instead, an independent ground of desert-counterfactual dependence-is the basis of liability. On such a theory, the ability or capacity of the defendant to have prevented the harm - the harm's counterfactual dependence on the omission - does the work of establishing responsibility. See Michael Moore 'Causing, Aiding, and the Superfluity of Accomplice Liability' (2007) 156 U Penn LR 395, 428.

${ }^{232}$ Morby (1882) 8 QBD 571.

${ }^{233}$ Ibid.
} 
will not arise if the parent's intervention would not have made any difference to the resulting harm.

These cases are exceptions to the foundational principle that criminal liability does not arise for failing to prevent a specific harm from occurring. The passer-by who watches a child drown is not liable for murder. The parent or lifeguard may be liable, as may be someone who inadvertently knocked the child into the water. This principle is rooted in concerns for individual autonomy and negative liberty, ${ }^{234}$ and is one to which the common law has a longstanding attachment. ${ }^{235}$ A duty to avert harm seeks to compel people to act in a particular way, potentially contrary to how they might ordinarily have chosen to act for themselves. With a typical incrementalism, the common law has carved out exceptions to this general principle. Capacity establishes that the failure to act is a factual cause of the harm. ${ }^{236}$ As is the case with actions, not all factual causes are seen as the legal cause of the harm. This is the role of the duty. In each case, the failure to act to avert the harm is seen as so culpable that the omission may be treated as the legal cause of the harm. ${ }^{237}$

\subsection{Principal Omissions and Complicit Omissions}

To reiterate, these duty cases establish principalship — the failure to act is seen as the legal cause of the resulting harm. ${ }^{238}$ The question, then, is whether a failure to act in

\footnotetext{
${ }^{234}$ Ashworth, 'Criminal Liability for Omissions' 427.

${ }^{235}$ Simester et al, Simester and Sullivan's Criminal Law 69.

${ }^{236}$ Andrew Ashworth, Principles of Criminal Law 111.

${ }^{237}$ See Fletcher, Rethinking Criminal Law 611; Helen Beynon, 'Causation, Omissions and Complicity' (1987) Crim. L. Rev. 539; Arthur Leavens, 'A Causation Approach to Criminal Omissions' (1988) 76 Cal. L. Rev. 547.

${ }^{238}$ A broader discussion of controversies around the concept of causation is beyond the scope of this thesis. See e.g. Ernest Weinrib, 'A Step Forward in Factual Causation' (1975) 38 MLR 518; Hart and
} 
accordance with a duty may give rise to accomplice liability. There is no reason that it should not. If we are willing to accept that certain omissions are the legal cause of a resulting harm, there is no reason that certain omissions should not be seen to constitute complicity in the bringing about of the harm by another actor. In some cases, distinguishing the two might be difficult. One way to determine whether the person who fails to perform his duty should be assessed as a principal or accomplice is the factual presence of another cause of the resulting harm. This point may be illustrated in the following scenarios:

A1. As in Pittwood, the defendant intentionally omits to close a railway gate and a train strikes the victim. The train driver is faultless. ${ }^{239}$

A2. A cleaner intentionally omits to lock the doors of a bank in the knowledge that it will assist in a bank robbery. ${ }^{240}$

Under the duty analysis set out above, the railway gate attendant may be liable for the resulting harm. In respect of A2, Ashworth suggests there is no difficulty in seeing the cleaner as an accomplice to the bank robbery. ${ }^{241}$ This is surely correctthe cleaner was under a duty to lock the doors and his intentional failure to act rendered assistance to the principal perpetrators. Indeed, this case seems to epitomise and justify the recognition of the category of complicit omissions in criminal law.

In other situations, it might be more difficult to distinguish principals from accomplices. Compare the following scenarios:

B1. A child falls into a swimming pool. His father, a strong swimmer, watches him drown.

\footnotetext{
Tony Honoré, Causation and the Law; Michael Moore, 'The Metaphysics of Causal Intervention' (2000) 88 Cal. L. Rev. 827.

${ }^{239}$ Pittwood.

${ }^{240}$ See Ashworth, Principles of Criminal Law 410-411

${ }^{241}$ Ibid.
} 
B2. A child is pushed into the swimming pool by his mother. Again, the father watches him drown. ${ }^{242}$

Under the duty analysis set out above, the father in B1 may be liable for the resulting harm. But what of the father in B2? It is difficult to distinguish the moral blameworthiness of the father's omission in B1 from that in B2. In both cases, he owed a duty to prevent harm to the child and failed to act accordingly. This might suggest treating both parents as principals. However, in the second scenario, we might also ask whether or not the father's omission aided the mother's act of murder. It would seem that it did. ${ }^{243}$

The answer probably lies in how we construct the father's duty. On one hand, the father's duty may be thought of as an obligation to prevent the child's death. On the other, it may be thought of as an obligation to prevent the child from being killed by another actor. ${ }^{244}$ If we construct the duty along the former lines, the failure to prevent the child's death in breach of the duty constitutes principalship. If we construct it along the latter lines, the failure to prevent the other actor from killing the child gives rise to accomplice liability. ${ }^{245}$

\subsubsection{Conclusion on Issue One of the Analytical Framework: Forms of Complicity}

As a theoretical matter, then, omissions can constitute complicity in the wrong of another actor. The existence of a specific duty to prevent harm, combined with the ordinary mens rea requirements of the particular doctrine, makes the omission

\footnotetext{
${ }^{242}$ See generally Alexander, 'Criminal Liability for Omissions: An Inventory of Issues' 121

${ }^{243}$ See $R v$ Russell (1933) VLR 59.

${ }^{244}$ See Gardner, 'Complicity and Causality’ 134.

${ }^{245}$ I am grateful to John Gardner for discussion on this point.
} 
sufficiently culpable. Beyond omissions, it will be seen that there is a disparity in the forms of complicity prohibited by complicity rules binding individuals and states, respectively, in international law. To a large extent, these differences may be explained by reference to the formation and constitution of the rules in each regime. Like much domestic criminal law, international criminal law has benefited from the prescription of broad principles of criminal responsibility in the context of complicity. Courts and tribunals have thus had a chance to refine the doctrines in pursuit of a coherent approach to complicit conduct. The starting point in state complicity was quite different. Before the acceptance of the rule reflected in Article 16 ARSIWA, complicity rules arose on a very specific and ad hoc basis in response to particularly culpable forms of assistance in particular wrongs. Even with the acceptance of Article 16, doubts exist as to the inclusion of certain kinds of complicity within its scope. $^{246}$

These differences have implications for the coherence of international law's approach to complicity in grave wrongdoing. For instance, it is undoubted that encouragement may give rise to aiding and abetting liability in international criminal law. ${ }^{247}$ So if a state agent, say a head of state, encourages the home secretary of another state to commit genocide, and genocide is committed, international criminal liability for complicity in genocide might arise. It is not clear, however, that the primary rule of complicity in genocide binding states or the secondary rule of aid and assistance reflected in Article 16 encompasses psychological influence in addition to physical help. ${ }^{248}$ On this interpretation, the head of state may be criminally liable for

\footnotetext{
${ }^{246}$ See Ch. 7.3.5 below.

${ }^{247}$ Tadić (Appeals Chamber Judgment) [229].

${ }^{248}$ Bosnian Genocide [419]; ARSIWA Commentary on Art 16.
} 
the crime of genocide without his state being responsible for the wrong of genocide. ${ }^{249}$ This matter is picked up in Chapter 9.

\subsubsection{Issue Two: The Nexus Requirement}

The first part of the analytical framework concerned the forms of complicity prohibited. The second concerns the nexus between the accomplice's acts and the principal's wrong. The term complicity itself denotes a certain kind of relationship between the two. In this respect, there are two challenges. The first is to understand the nature of that relationship. The second is to define the lower boundary of the requisite connection.

Starting with the nature of the relationship, Sanford Kadish seeks to account for complicity in non-causal terms. For him, the moral relevance of voluntary action prevents an understanding of the conduct of accomplices as causal. ${ }^{250}$ Voluntary $^{2}$ action, in this sense, finds expression in the doctrine of novus actus interveniens. ${ }^{251}$ On his account, causal chains between actions and occurrences are irrevocably split by the volitional conduct of a second actor. ${ }^{252}$

Kadish's account is not satisfactory in its denial that accomplices make a causal contribution to the wrong committed by the principal. As Gardner argues:

Many people ... are tempted to say that people, as responsible agents, have free will and defy causality. Causal chains therefore cannot run

\footnotetext{
${ }^{249}$ See Ch. 9.2.5.2 below; André Nollkaemper, 'The Charles Taylor Judgment: Disconnecting the Responsibilities of Presidents and States' (SHARES Blog, 1 October 2013) available at $<\mathrm{http}$ ://www.sharesproject.nl/the-charles-taylor-judgment-disconnecting-the-responsibilities-ofpresidents-and-states/> accessed 3 October 2013.

${ }^{250}$ Kadish, 'Complicity, Cause and Blame' 334-335.

${ }^{251}$ Ibid 335.

${ }^{252}$ Ibid.
} 
to or through their actions... So it is often said... When I pay a hitman to kill an enemy it is a straightforward consequence of what I do that the hitman kills my enemy, and hence that my enemy dies... I procure the killing and I also cause, through the hitman, the death. There is a straightforward causal explanation of how it all unfolds, action and reaction, antecedent and consequent. None of this wipes out the hitman's part in the story as a responsible agent. ${ }^{253}$

A better approach is to view complicity as entailing an indirect causal contribution to the wrong. ${ }^{254}$ Here it is useful to refer back to Kadish's differentiation of the two paradigm forms of complicity: helping the perpetrator to commit the wrong and influencing the decision of the perpetrator to do so. ${ }^{255}$ When considering conduct that helps the perpetrator to commit the wrong, in the central case the accomplice makes a different kind of causal contribution to the wrong from the principal. ${ }^{256}$ The accomplice's causal contribution is indirect. Imagine A gives $\mathrm{P}$ a knife and $\mathrm{P}$ uses the knife to cause result R. P causes the result R. A makes a causal contribution to P's causing of result $\mathrm{R}^{257}$ Accomplices make 'a difference to the difference that principals make. ${ }^{258}$

This analysis is more complicated where the accomplice influences the decision of the principal to commit the wrong. In addition to an assumed conflict with our attachment to the volition of the principal, ordinary cases of encouragement or abetment are plagued by underdetermination. ${ }^{259}$ Along the lines suggested by

\footnotetext{
${ }^{253}$ Gardner, 'Complicity and Causality’ 136-137.

${ }^{254}$ Smith, A Treatise on Complicity 89.

${ }^{255}$ Kadish, 'Complicity, Cause and Blame' 342.

${ }^{256}$ John Gardner, 'Moore on Complicity and Causality' (2008) U. Penn. L. Rev. Pennumbra 432, $437-$ 438 .

${ }^{257}$ Ibid 438.

${ }^{258}$ Gardner, 'Complicity and Causality' 128.

${ }^{259}$ Kutz, 'Causeless Complicity’ 299.
} 
Gardner, A's acts must make an indirect causal contribution to the wrong; that is to say, a causal contribution to A's decision to commit the wrong. The inscrutability of the mind causes grave evidentiary difficulties in determining whether a shout of encouragement had an effect on P's decision. ${ }^{260}$ Smith gives the example of a principal who has settled on a criminal course of action. Before commencing, he is encouraged by A. In this instance, A's encouragement may be causally superfluous or causally relevant in strengthening P's faltering resolve. ${ }^{261}$ It is very difficult to tell.

These evidentiary difficulties are not easily overcome. The most convincing explanation is Smith's. In cases of psychological influence, attempted acts of encouragement of which the principal is aware are assumed to act on his mind. ${ }^{262}$ In other words, they are taken to have causally contributed to his decision. In some respects, the doctrine of presumed effect renders complicity by psychological assistance similar to attempts liability — a culpable mental state together with some minor conduct gives rise to liability. ${ }^{263}$ Yet it is different in a crucial aspect. The presumption of causal contribution may be rebutted by evidence that the encouragement played no role in the principal's decision. ${ }^{264}$ This would not be encouragement or abetment but a failed attempt at such. Another way to put this is that acts of assistance must actually assist and acts of encouragement must actually encourage. $^{265}$

\footnotetext{
${ }^{260}$ Ibid.

${ }^{261}$ Smith, A Treatise on Complicity 85.

${ }^{262}$ Ibid 87. See also Law Commission, Participating in Crime (Law Com No 305, 2007) [2.37]-[2.39].

${ }^{263}$ Weisberg, 'Reappraising Complicity' 231.

${ }^{264}$ Smith, A Treatise on Complicity 87.

${ }^{265}$ Gardner, 'Complicity and Causality' 137.
} 
This formulation leads to the second question — what is the lower boundary of the requisite connection between the acts of assistance or encouragement and the principal's wrong? At a bare minimum, we know that the assistance or encouragement must be successful. ${ }^{266}$ In some cases, it will be possible to categorise the accomplice's actions as a sine qua non of the principal's commission of wrongdoing - say, for instance, the cleaner who intentionally omitted to lock the door of the bank. ${ }^{267}$ Here, the wrong would not have come into existence without the cleaner's omission. ${ }^{268}$ There are plainly other cases in which the complicit conduct is not a sine qua non of the principal's wrong-for example, the principal would have been able to obtain the weapon from another seller if the putative accomplice had refused to sell. ${ }^{269}$ However, the fact that certain assistance or encouragement was not a sine qua non does not mean that it made no contribution to it at all.

In prohibiting such contributions, complicity rules ought to apply a substantiality requirement. ${ }^{270}$ Given the range of conduct that might fulfill the conduct element of complicity, including trivial contributions would result in overcriminalisation for individuals ${ }^{271}$ and an undue limitation on free intercourse among nations for states. ${ }^{272}$ Moreover, as the connection approaches a de minimis standard, it starts to become inconsistent with the essential derivative nature of complicity. The

\footnotetext{
${ }^{266}$ Kadish, 'Complicity, Cause and Blame' 357.

${ }^{267}$ See Ashworth, Principles of Criminal Law 410-411.

${ }^{268}$ Gardner, 'Complicity and Causality' 137.

${ }^{269}$ Ibid 138 . This point is affected by how stringently the wrongful event is defined. If the wrong is defined in terms of how exactly it occurred, then plainly any contribution is a sine qua non cause of that specifically defined wrong. See Dressler, 'Reforming Complicity Law' 441.

${ }^{270}$ Smith, A Treatise on Complicity 86-88; Moore, 'The Superfluity of Accomplice Liability' 421. See also Dressler, 'Reforming Complicity Law'.

${ }^{271}$ Kadish, 'Complicity, Cause and Blame' 363.

${ }^{272}$ Lowe, 'Responsibility for the Conduct of Other States' 5.
} 
logic of complicity is to link the accomplice's conduct to the wrong itself, either through imputational responsibility or through a model of participation that renders the accomplice responsible for instigating torture or facilitating murder, as the case may be. ${ }^{273}$ Such judgments ought to be dependent on at least a substantial contribution to the wrong.

\subsubsection{Issue Three: The Fault of the Accomplice}

\subsubsection{Introduction}

The third plank of the analytical framework concerns the fault required of the accomplice. By nature, the fault required in complicity is complicated-the presence of an accomplice adding another element to issues relating to the intersection of actus reus and mens rea. ${ }^{274}$ Experience shows that accomplices may assist or encourage a principal with a spectrum of attitudes. ${ }^{275}$ As Smith puts it:

There is no natural or automatically ascertainable proper level of mental involvement or culpability; it is a normative issue of what mental states, bearing in mind the social circumstances and consequences and possibilities for control, ought to be taken as appropriate subjects of criminal sanction. ${ }^{276}$

More fundamentally, how we think about the fault element may depend on the structure of the complicity rule at issue. ${ }^{277}$ Where complicity rules are imputational, we should be concerned with the relationship between the fault required for the principal wrong and the fault required of the accomplice. Where complicity is not imputational, it is possible to conceive of a detailed scheme of responsibility,

\footnotetext{
${ }^{273}$ See Smith, A Treatise on Complicity 88.

${ }^{274}$ Sanford Kadish, 'Reckless Complicity’ (1987) 2 J. Crim L. \& Criminology 369.

${ }^{275}$ Smith, A Treatise on Complicity 142.

${ }^{276}$ Ibid 154.

${ }^{277}$ Antony Duff, ““Can I Help You?” Accessorial Liability and the Intention to Assist' (1990) 10 Legal Stud. 165, 167-168.
} 
combining specific forms of complicity with specific mental states. We would be able to capture normatively significant differences in the different forms of fault with which accomplices act.

Nonetheless, no matter the structure of the rule, it is vital to determine what kinds of fault are appropriate for complicity. Two overriding concerns pervade the literature and domestic case law. ${ }^{278}$ First, must accomplices share the purpose of the principal or is it sufficient that they know of that criminal purpose? Second, if knowledge is the appropriate standard, what exactly must the accomplice know? These two concerns merge to throw up a third issue: is there a role for reckless complicity rules?

\subsubsection{Purpose or Knowledge}

Intentional wrongdoing is more blameworthy than reckless wrongdoing. ${ }^{279}$ At its core, to act intentionally is to act in order to bring about a particular result. ${ }^{280}$ Here, the result obtained corresponds to the agent's purpose in acting. ${ }^{281}$ Ordinarily, intention also includes virtually certain side-effects of action. ${ }^{282}$ So if a villain blows up an aircraft in order to collect the insurance, we would still say that he intended the deaths of the passengers, even though this was not his purpose. ${ }^{283}$ The lesson here is that the legal category of intention extends beyond the narrow linguistic sense of

\footnotetext{
${ }^{278}$ See Smith, A Treatise on Complicity 141-196.

${ }^{279}$ See Fletcher, Rethinking Criminal Law 442-449.

${ }^{280}$ Duff, Intention, Agency and Criminal Liability 72.

${ }^{281}$ Glanville Williams, 'Oblique Intention' (1987) 46 Camb. L. J. 417, 418. See also Ashworth, Principles of Criminal Law 171-172.

${ }^{282}$ Simester et al, Simester and Sullivan's Criminal Law 132.

${ }^{283}$ Williams, 'Oblique Intention' 423. See also Hyam v DPP [1975] AC 55, 77 (Lord Hailsham).
} 
'intending' to include an assessment of responsibility. ${ }^{284} \mathrm{We}$ are responsible not only for consequences we act in order to bring about but also those we know will occur in the ordinary course of events.

The presence of the accomplice makes the distinction between knowledge (that wrongdoing will occur) and purpose (to assist in the commission of wrongdoing) more salient. It is easy to think of cases where an accomplice's purpose or motive is to assist in the perpetration of the wrong. Duff gives the example of a supplier who sells materials to the principal and who will be paid from the proceeds of crime. ${ }^{285} \mathrm{~A}$ good way to identify this category of purposeful assisters is to ask if their action would have failed if the principal wrong were not committed. ${ }^{286}$ But what about the independent supplier who, purely in pursuit of profit, sells a gun to the principal in the knowledge of the principal's intentions, ${ }^{287}$ or the businessman who, bearing no ill will towards a particular ethnic group, knowingly sells chemical weapons to a dictator who commits genocide? ${ }^{288}$

In the United States, this question is sometimes cast as the 'true purpose' debate, anchored between Judge Learned Hand's opinion in Peoni and Judge Parker's in Backun. ${ }^{289}$ In Peoni, Judge Hand held that the words used to prohibit various modes of complicity_ aid, abet, counsel, procure, etc_-'carry an implication of

\footnotetext{
${ }^{284}$ Duff, Intention, Agency and Criminal Liability 72-73; Ashworth, Principles of Criminal Law 172. 
purposeful attitude... ${ }^{290}$ In other words, accomplices must provide their aid in order to assist the principal. This is the approach of the American Law Institute's Model Penal Code. ${ }^{291}$ In Backun, Judge Parker held that an otherwise lawful transaction could give rise to accomplice liability where the seller was advised of the purchaser's criminal intent; the seller cannot wash his hands of his aid. ${ }^{292}$ This is the prevailing approach in England and Wales: knowledge is sufficient for complicity. ${ }^{293}$

Resolving this issue is difficult for just as we might think that not every knowing assister should be liable, so is it difficult to argue that no such knowing assister should be liable. ${ }^{294}$ As noted above, non-imputational complicity rules might allow a narrow tailoring of conduct and culpability. ${ }^{295}$ But even in systems using non-imputational complicity rules, we need some sense of when the provision of help or influence should give rise to responsibility, even if we then provide a grading of culpability.

This issue cannot be settled by reference only to the words at issue. ${ }^{296}$ The usual argument against a standard of knowledge suggests that it is too burdensome to impose on actors carrying out their own lawful business an obligation to cease their activities to prevent harm carried out by another actor. ${ }^{297}$ Just as you are not an

\footnotetext{
${ }^{290}$ United States $v$ Peoni (1938) 100 F.2d 401 (2 ${ }^{\text {nd }}$ Cir.)

${ }^{291}$ Model Penal Code S2.06(3)(a). See Weisberg, 'Reappraising Complicity' 239; Robinson, 'Imputed Criminal Liability' n.100.

${ }^{292}$ Backun v United States (1940) 112 F.2d 635 (4 ${ }^{\text {th }}$ Cir.).

${ }^{293}$ DPP for Northern Ireland v Lynch [1975] AC 653. See Smith, A Treatise on Complicity 143-150.

${ }^{294}$ Duff, 'Can I Help You' 177.

${ }^{295}$ Ibid 181; Smith, A Treatise on Complicity 157-160; Weisberg, 'Reappraising Complicity’ 264.

${ }^{296}$ Smith, A Treatise on Complicity 33; Ashworth, Principles of Criminal Law 99. Cf Peoni 402.

${ }^{297}$ Smith, A Treatise on Complicity 153; Duff, 'Can I Help You' 178.
} 
accomplice to murder if you walk past a stranger bleeding to death from a gunshot wound, so continuing your ordinary lawful activities in the knowledge of another's criminal intention should not make you an accomplice to their wrong. ${ }^{298}$

This argument is not conclusive. In the first place, even if we think that philosophical concerns for individual autonomy mean that there should be no legal duty to save the stranger, these concerns are diminished when the duty simply demands that a shopkeeper refrain from making a sale. Secondly, concerns regarding the excessive hampering of trade are overstated. It will be a rare case that an ordinary shopkeeper knows that his customer intends to commit a crime. This is true whether she is selling screwdrivers, cricket bats, or cleaning materials. In situations where the object of trade is more likely to be connected to crime - automatic weapons or substances often used as poisons, for instance - it is not over-burdensome to require that the seller refrain from assisting those who she knows intend to commit a crime. The culpability of a businessman who sells chemical weapons for profit in the knowledge of the buyer's criminal intention is not significantly lower than the purposeful supplier. ${ }^{299}$

It should be conceded that this might bring into the ambit of complicity certain knowing assisters who act with benevolent intentions. In Gillick, for instance, a doctor prescribed contraception to a girl under the age of 16 on the basis of his medical judgment. ${ }^{300}$ Presumably the doctor would have known that he would

\footnotetext{
${ }^{298}$ Duff, 'Can I Help You' 178.

${ }^{299}$ Smith, A Treatise on Complicity 154.

${ }^{300}$ Gillick $v$ West Norfolk and Wisbech Area Health Authority and the Department of Health and Social Security [1986] AC 112.
} 
thereby be facilitating the commission of unlawful sexual intercourse even though this was not his purpose in prescribing the contraception. ${ }^{301}$ In war, a prisoner might, under threats, inform his captors of the location of another soldier knowing that it would facilitate acts of ill-treatment. ${ }^{302}$ These concerns can be largely alleviated through creative use of the defences of necessity and duress. In Gillick, the doctor's provision of contraception would thus be excused on the basis of his honest and reasonable judgment that doing so was necessary for the girl's health. ${ }^{303}$ In the case of the prisoner threatened by his captors, the defence of duress might excuse his knowing assistance. ${ }^{304}$ Many of the situations in which we intuitively think it unfair to punish a knowing assister can be accommodated within ordinary doctrines of duress and necessity.

So as a general matter, knowledge that wrongdoing will follow ought to be sufficient to justify the label of complicity, as distinct from the specific purpose to assist in the wrongdoing. In the particular case, however, there may be complicating factors. For instance, the appropriate fault for accomplice liability may well depend on the strength of the nexus requirement between the help or influence and the principal's actions - the less stringent the connection, the more appropriate a demand for coincidence of purpose. ${ }^{305}$ In addition, some scholars have argued that the nature of the principal's wrong might affect our determination of what it means to be complicit therein. In international law, this argument arises principally in the context of specific intent crimes. Mettraux has argued that the essential character of genocide

\footnotetext{
${ }^{301}$ Simester et al, Simester and Sullivan's Criminal Law 221.

${ }^{302}$ See Erdemović (Appeals Chamber Judgment) IT-96-22-A (7 October 1997).

${ }^{303}$ JC Smith [1986] Crim L.R. 113, 117 (note); Duff, 'Can I Help You' 167.

${ }^{304}$ Cf Erdemović (Appeals Chamber Judgment).

${ }^{305}$ See Duff, 'Can I Help You' 166-168.
} 
demands that accomplices act with the specific intent of destroying the protected group. ${ }^{306}$ This issue will be addressed in Chapter 4.

It will be seen in Chapter 4 that the jurisprudence of the ad hoc tribunals shows a preference for a standard of knowledge. ${ }^{307}$ This is consistent with customary international law. ${ }^{308}$ The Rome Statute requires only knowledge for instigation under Article 25(3)(b) but demands that aiding and abetting under Article 25(3)(c) be done with the purpose of facilitating the commission of the crime. ${ }^{309}$ In the law of state responsibility, Article 16 ARSIWA introduces ambiguity by referring to both a knowledge and purpose standard. On one hand, the text of Article 16 requires that the aid or assistance be provided "with knowledge of the circumstances of the internationally wrongful act' committed by the principal state. ${ }^{310}$ On the other hand, the Commentary suggests that the rule is conditioned by a requirement that the aid or assistance 'be given with a view to facilitating the commission of the wrongful act...'311 The term 'with a view to facilitating' clearly contemplates purpose. In many cases, assisting states will act with both knowledge and purpose, but there will be instances where the difference is dispositive. This matter is addressed in Chapter 7.

\footnotetext{
${ }^{306}$ Guénaël Mettraux, International Crimes and the Ad Hoc Tribunals (OUP 2005) 212.

${ }^{307}$ See e.g. Blaškić (Appeals Chamber Judgment) IT-95-14-A (29 July 2004) [49]; Orić (Appeals Chamber Judgment) IT-03-68-A (3 July 2008) [43]. It will be seen that a degree of confusion has been introduced by the decision of the ICTY Appeals Chamber in Perišić (Appeals Chamber Judgment) IT04-81-A (28 February 2013) - see Ch. 4.3.1 below.

${ }^{308}$ See e.g. Zyklon B - Trial of Bruno Tesch and Two Others (8 March 1946) (1947) I LRTWC 93; Prosecutor v Taylor (Appeals Chamber Judgment) SCSL-03-01-A (26 September 2013) [413]-[437]. See also Van Sliedregt, Individual Criminal Responsibility 128-130.

${ }^{309}$ Arts 25(3)(b), 25(3)(c) Rome Statute.

${ }^{310}$ Art 16 ARSIWA.

${ }^{311}$ ARSIWA Commentary on Art 16 [5].
} 


\subsubsection{Specificity of Knowledge}

If accomplices must act with knowledge, what exactly must they know? In the common law, the classic formulation is Lord Goddard's in Johnson v Youden: 'Before a person can be convicted of aiding and abetting the commission of an offence he must at least know the essential matters which constitute the offence. ${ }^{312}$ In many cases, this is a workable test: the accomplice stands guard while watching the principal break into a bank, or encourages the principal to vandalise a car. But in other cases, the relationship between the accomplice's knowledge and the crime that eventuates might be more complicated. ${ }^{313}$ In this respect, four situations may be imagined:

1. A drives $\mathrm{P}$ to V's house knowing that he intends to commit a battery against $\mathrm{V}$. $\mathrm{P}$ commits battery against $\mathrm{V}$.

2. A drives $P$ to $V$ 's house knowing that he intends to commit a battery against $\mathrm{V}$ and/or rob him. $\mathrm{P}$ robs $\mathrm{V}$.

3. A drives $\mathrm{P}$ to $\mathrm{V}$ 's house knowing that he intends to commit a battery against him. Instead, $\mathrm{P}$ commits grievous bodily harm against $\mathrm{V}$.

4. A drives $\mathrm{P}$ to V's house knowing that he intends to break into his house. $\mathrm{P}$ breaks into the house and murders $\mathrm{V}$.

Situation 1 is the paradigm case of accomplice liability. Other cases are not quite as straightforward. In Maxwell, the defendant drove a lead car that guided another car to an inn that was to be attacked by members of the Ulster Volunteer Force. ${ }^{314}$ The trial judge found an irresistible inference that Maxwell knew that the job he was contributing to involved an attack of violence in which people would be endangered or premises seriously damaged. ${ }^{315}$ In response, Maxwell's counsel

\footnotetext{
${ }^{312}$ Johnson $v$ Youden [1950] 1 KB 544, 546.

${ }^{313}$ For comprehensive treatment, see Smith, A Treatise on Complicity 161-196.

${ }^{314}$ Maxwell v DPP for Northern Ireland [1979] 68 Cr. App. R. 128.

${ }^{315}$ Maxwell 132.
} 
argued that on the basis of the 'essential matters' test, he did not know which crime was to be committed.

Maxwell's appeal was dismissed, though on the basis of different tests. ${ }^{316}$ Lord Scarman proposed a test that asks whether the actual crime committed was at least one of any number of crimes within the accomplice's contemplation. ${ }^{317}$ So in the second situation, A contemplated both robbery and battery in his provision of aid and would thus be responsible as an accomplice to the crime that occurred.

Scarman's colleagues proposed a different test, sourced in Parker CJ's judgment in Bainbridge: 'there must be not merely suspicion but knowledge that a crime of the type in question was intended. ${ }^{, 318}$ This corresponds to the third situation: A believed that $\mathrm{P}$ intended to commit a battery against $\mathrm{V}$ but he actually committed grievous bodily harm. Neither of the two tests in Maxwell would hold A responsible in situation 4, where the accomplice assists, contemplating a burglary, but the principal commits murder.

The issue of specificity of knowledge arises in international law. In respect of international criminal law, the ICTY and ICTR have articulated both an 'essential matters' test along the lines of Johnson v Youden, ${ }^{319}$ as well as a test that requires only that the accomplice contemplated that one of a number of crimes would be

\footnotetext{
${ }^{316}$ See Smith, A Treatise on Complicity 165-169.

${ }^{317}$ Maxwell 153 (Lord Scarman).

${ }^{318}$ Bainbridge [1960] 1 QB 129, 133 (Lord Parker); Maxwell 148 (Lord Hailsham) (emphasis added).

${ }^{319}$ See Haradinaj, Balaj, Brahimaj (Appeals Chamber Judgment) IT-04-84-A (19 July 2010) [58]; Orić (Appeals Chamber Judgment) [43]; Mrkšić, Šljivančanin (Appeals Chamber Judgment) IT-9513/1A (5 May 2009) [159]; Simić (Appeals Chamber Judgment) IT-95-9-A (28 November 2006) [86].
} 
committed, of which the actual crime was one, even if he did not know exactly which it was to be. ${ }^{320}$ In respect of state complicity, states' interactions with each other are often complicated; aid may be provided without certainty of the range or extent of the recipient state's intentions. Complicity rules must grapple with these complications.

\subsubsection{Reckless Complicity}

Thus far we have seen that complicity rules prompt a choice between a standard of knowledge and one of purpose, and, in the event that knowledge is to be sufficient for responsibility, must determine what exactly the accomplice must know. What about reckless complicity? The distinction between acting intentionally and acting recklessly entails a critical judgment as to culpability, rendering demarcation of the boundary important. ${ }^{321}$ The classic case concerns the provision of assistance in situations where the accomplice is not certain that the principal is intending to commit the crime. ${ }^{322}$ Kadish gives the example of a bed-ridden employee who gives the code to his employer's safe to a career criminal, $\mathrm{P}$, so that $\mathrm{P}$ can bring him some documents from the safe. ${ }^{323}$ The employee's purpose in giving the codes is not to help P to steal. Likewise, he does not know that $\mathrm{P}$ is intending to commit the crime. But knowing that his helper is a career criminal, the employee certainly is aware of a risk that his provision of the codes will assist in the commission of theft. ${ }^{324}$

\footnotetext{
${ }^{320}$ See Haradinaj et al (Appeals Chamber Judgment) [58]; Mrkš̌ić, Šljivančanin (Appeals Chamber Judgment) [159]; Simić (Appeals Chamber Judgment) [86].

${ }^{321}$ See Fletcher, Rethinking Criminal Law 442-449.

${ }^{322}$ This question also arises where assistance is provided for the purposes of the commission of a specific crime and additional crimes are committed. In this respect, there are links to the extended form of joint venture.

${ }^{323}$ Kadish, 'Reckless Complicity' 371.

${ }^{324}$ Ibid.
} 
Comparative analyses of recklessness are rendered difficult by the subtle distinctions in how legal systems grade mental states short of actual knowledge. ${ }^{325}$ Assessments of risk-taking ordinarily revolve around three foci: the gravity of the risk, the social utility of taking the risk, and the risk-taker's subjective posture towards that risk. ${ }^{326}$ For current purposes, the American Law Institute's Model Penal Code's formulation will suffice: 'A person acts recklessly with respect to a material element of an offence when he consciously disregards a substantial and unjustifiable risk that the material element exists or will result from his conduct. ${ }^{327}$

A system of non-imputational complicity rules may prohibit reckless complicity with few theoretical complications. In imputational systems, leaving aside the principled objection to imputation itself, the issue is more difficult: are reckless acts of encouragement or assistance sufficiently culpable to justify finding the assister responsible for the principal's crime? Framed like this, the answer is no. Forget, for a minute, principal offences defined by recklessness and focus on intentional offences. To hold a principal responsible for an intentional offence-murder, for instance - she must actually bring about the prohibited harm and do so intentionally. It is this intersection of conduct and fault that justifies the imposition of criminal liability. ${ }^{328}$ And so it is for the accomplice. It would plainly be inconsistent with the principle of culpability to hold an accomplice responsible for an intentional offence on the basis of his recklessness.

\footnotetext{
${ }^{325}$ Fletcher, Rethinking Criminal Law 442-449.

${ }^{326}$ Ibid 260-261.

${ }^{327}$ MPC S2.02(2)(c).

${ }^{328}$ Simester, 'The Mental Element in Complicity' 590.
} 
It is worth noting that between intention and recklessness lies the doctrine of wilful blindness. Glanville Williams defines the doctrine in the following terms:

A court can properly find wilful blindness only where it can almost be said that the defendant actually knew. He suspected the fact; he realised its probability; but he refrained from obtaining the final confirmation because he wanted in the event to be able to deny knowledge. This, and this alone, is wilful blindness. ${ }^{329}$

Williams notes that the rule is somewhat unstable and liable to unjustified extension by judges. ${ }^{330}$ It is not simply a judgment that the potential accomplice took an unjustifiable risk by not inquiring into the principal's intentions. This would render wilful blindness indistinguishable from the lower standard of recklessness. ${ }^{331}$ Rather, it arises where the accomplice either (i) shuts his eyes because he is virtually certain of the answer that his enquiries would bring, or (ii) strongly suspects the truth of the principal's intentions but refuses to enquire so as not to know. ${ }^{332}$ In both cases, the imposition of liability in a situation falling short of the ordinary mental element is justified by the accomplice's additional fault in deliberately shutting his eyes having been adverted to the risk. ${ }^{333}$ If limited in this way, the doctrine of wilful blindness may be seen as a justified extension to the category of knowledge.

\subsubsection{Analytical Framework: Conclusion}

This section built an analytical framework for understanding complicity rules. It consists of three questions any legal system must answer in order to prescribe a complicity rule: the forms of complicity prohibited, the nexus between the

\footnotetext{
${ }^{329}$ Williams, The General Part 159.

${ }^{330}$ Ibid.

${ }^{331}$ Simester et al, Simester and Sullivan's Criminal Law 150.

332 Ibid.

${ }^{333}$ M. Wasik and M.P. Thompson, “"Turning a Blind Eye” as Constituting Mens Rea' (1981) 32 NILQ 328, 330-331.
} 
accomplice's acts and the principal's wrong, and the fault required of the accomplice. The three elements of the rule are inter-dependent, as the resolution of each influences the appropriate answer to the others. The framework is used throughout the thesis to provide an analytical account of the ways in which international law responds to state and individual complicity.

\subsection{CONCLUSION}

This chapter accomplished four things. First, it provided a definition of complicity that delimits the scope of the thesis. This definition views doctrines of complicity as establishing a derivative form of responsibility for participating in the wrongdoing of another actor. In thinking about the kinds of conduct that constitute complicity, the distinction between helping the principal and influencing the principal is useful. Second, the chapter assessed the wrongness of complicity. Where the principal's act is morally wrongful, it follows that the accomplice should not participate in that wrong. In respect of legal wrongs, the justification and/or demand for a complicity rule turns on conflicting rationales shaped by the needs and purposes of the legal system itself.

Third, this chapter assessed how complicity rules are structured, an assessment that results in a strong preference for complicity rules that hold accomplices responsible for their own contribution to the principal's wrong, rather than for the wrong committed by the principal. Finally, it built an analytical framework around the three questions that must be answered by any legal system seeking to prohibit complicity. These questions concerned the forms of complicity prohibited, the nexus 
between the accomplice's acts and the principal's wrong, and the fault of the accomplice.

Parts B and C of the thesis - Chapter 3 through 9-provide an account of complicity rules binding individuals and states in international law. The analytical framework built in this chapter enriches the account of complicity in each of the chapters. The normative claim of the thesis - a preference for non-imputational complicity — is used as an evaluative standard against which to assess the structure of the rules. This approach allows for an account of complicity in international law that is analytical and evaluative. The concluding chapter, Chapter 10, draws together these threads. 


\section{Part B. Complicity in International Criminal LaW}

\section{CHAPTER 3. INDIVIDUAL CRIMINAL RESPONSIBILITY}

\subsection{INTRODUCTION}

Part B of the thesis - Chapters 3, 4, and 5-provides an account of complicity in international criminal law. Complicity rules establish a derivative form of responsibility for participating in wrongdoing committed by another actor. That participation entails the provision of help to, or influence on, the principal wrongdoer. $^{334}$

The present chapter-Chapter 3 - defines the scope of Part B and briefly assesses the principle of individual criminal responsibility in international law. Chapter 4 analyses two paradigm doctrines prohibiting complicity in international criminal law: instigation and aiding and abetting. It also assesses the controversy surrounding the putative crime of complicity in genocide arising under the statutes of the $a d$ hoc tribunals. ${ }^{335}$ Its approach is to set out and resolve various doctrinal issues arising in the case law and scholarship, assess the rules within the analytical framework of the thesis, and evaluate the rules against the thesis' normative claim as to the optimal structure of complicity rules. This framework centers the analysis on three axes: the forms of complicity prohibited, the nexus between the accomplice's act and the principal's wrong, and the fault required of the accomplice. The normative claim establishes a preference for non-imputational complicity rules.

\footnotetext{
${ }^{334}$ Kadish, 'Complicity, Cause and Blame' 342.

${ }^{335}$ Statute of the International Criminal Tribunal for the Former Yugoslavia adopted by UNSC Res 827 (25 May 1993) UN Doc S/RES/827; Statute of the International Criminal Tribunal for Rwanda adopted by UNSC Res 955 (8 November 1994) UN Doc S/RES/955.
} 
Chapter 5-the final chapter in Part B-addresses international criminal law's response to complicit omissions. That response takes two forms. First, the idea of aiding and abetting by omission has received increased attention and recognition in the jurisprudence of the ICTY and ICTR. This recognition should be supported. As a matter of fact, certain omissions do help or influence the decision of a perpetrator to commit a crime. As a normative matter, omissions may be sufficiently wrongful so as to justify the imposition of accomplice liability. Second, international criminal law establishes, through the doctrine of command responsibility, a special form of responsibility for complicit omissions. Indeed, the most culpable form of command responsibility - a failure to prevent the perpetration of crimes by subordinates with actual knowledge of their intended commission — adds little, if anything, to the rule of aiding and abetting by omission. Command responsibility also establishes a rule of negligent complicity by imputing to superiors crimes of their subordinates about which they ought to have known.

\subsection{The SCOPE OF PART B OF THE THESIS}

Part B assesses the criminal law doctrines of instigation and aiding and abetting, as well as international criminal law's response to complicit omissions. It does not discuss a number of kindred forms of responsibility arising in international criminal law. These kindred forms of responsibility include the extended form of joint criminal enterprise liability and incitement to commit genocide. ${ }^{336}$ The extended form of joint

\footnotetext{
${ }^{336}$ See generally Allison Danner and Jenny Martinez, 'Guilty Associations: Joint Criminal Enterprise, Command Responsibility, and the Development of International Criminal Law' (2005) 93 Calif. L. Rev. 75; Attila Bogdan, 'Individual Criminal Responsibility in the Execution of a "Joint Criminal Enterprise" in the Jurisprudence of the ad hoc International Tribunal for the Former Yugoslavia' (2006) 5 Intl Crim. L. Rev. 63; Kai Ambos, 'Joint Criminal Enterprise and Command Responsibility' (2007) 5 J. Intl Crim. J. 159; Jens Ohlin, 'Incitement and Conspiracy to Commit Genocide' in Paola Gaeta (ed.), The UN Genocide Convention: A Commentary (OUP 2009) 207.
} 
criminal enterprise should be seen as a complementary doctrine to complicity. ${ }^{337}$ It replicates the structure of imputational complicity in providing a rule by which the acts of the principal perpetrator are attributed to the participant in a $\mathrm{JCE}^{338} \mathrm{In}$ imputational complicity, the trigger for imputation is the accomplice's acts of help or encouragement. In joint criminal enterprise, the trigger is the defendant's participation in a common enterprise. As in respect of the accomplice's acts in imputational complicity, the law treats this decision to participate as morally significant enough to associate the defendant with the deviatory but foreseeable conduct of his confederates. ${ }^{339}$

Incitement to commit genocide refers to conduct that might constitute instigation or abetment of genocide under ordinary doctrines of complicity. ${ }^{340}$ However, it is founded in law at the moment the incitement occurs and is not dependent on the subsequent commission of the incited offence-incitement to commit genocide may be committed without genocide being perpetrated. ${ }^{341}$ For this reason, it is not a derivative form of responsibility, and is therefore not a doctrine of complicity, but is rather a supplementary inchoate crime. ${ }^{342}$

\footnotetext{
${ }^{337}$ See Smith, A Treatise on Complicity 209-234.

${ }^{338}$ See Kai Ambos, 'Amicus Curiae Brief in the Matter of the Co-Prosecutors' Appeal of the Closing Order against Kaing Guek Eav “Duch” Dated 8 August 2008' (2009) 20 Crim. L. Forum 353, 369 referring to JCE II and III as 'autonomous (systemic) concepts of imputation.' See also Pinkerton v United States 328 US 640 (1946).

${ }^{339}$ Simester, 'The Mental Element in Complicity' 598-599.

${ }^{340}$ See William Schabas, Genocide in International Law: The Crime of Crimes ( $2^{\text {nd }}$ ed., CUP 2009) 319; Akayesu (Appeals Chamber Judgment) ICTR-96-4 (1 June 2001) [478].

${ }^{341}$ Nahimana, Barayagwiza, Ngeze (Appeals Chamber Judgment) ICTR-99-52-A (28 November 2007) [678].

342 Ibid.
} 
In addition to the exclusion of joint criminal enterprise and incitement to commit genocide, this chapter also does not discuss the prohibition on contributions to group crime set out in Article 25(3)(d) of the Rome Statute. ${ }^{343}$ In contrast to the first two doctrines, the reason for exclusion here is pragmatic rather than conceptual. Using language borrowed from Article 2(3)(c) of the International Convention for the Suppression of Terrorist Bombing, ${ }^{344}$ the provision creates a complicated and much criticised mode of participating in one of the crimes within the jurisdiction of the Court. ${ }^{345}$ Although the cases of Mbarushimana and Ruto have clarified certain issues relating to the scope of the doctrine, notably that contributions by members of the group itself, as well as by non-group members, may give rise to liability, ${ }^{346}$ responsibility pursuant to Article $25(3)(\mathrm{d})$ is somewhat residual. ${ }^{347}$ For reasons of scope, the primary focus of the thesis is on the doctrines of instigation and aiding and abetting, together with international law's response to complicit omissions.

${ }^{343}$ Art 25(3)(d) Rome Statute: 'In accordance with this Statute, a person shall be criminally responsible and liable for punishment for a crime within the jurisdiction of the Court if that person:

In any other way contributes to the commission or attempted commission of such a crime by a group of persons acting with a common purpose. Such contribution shall be intentional and shall either:

(i) Be made with the aim of furthering the criminal activity or criminal purpose of the group, where such activity or purpose involves the commission of a crime within the jurisdiction of the Court; or

(ii) Be made in the knowledge of the intention of the group to commit the crime.

${ }^{344}$ Art 2(3)(c) International Convention for the Suppression of Terrorist Bombings (adopted 15 December 1997, entered into force 23 May 2001) 2149 UNTS 284.

${ }^{345}$ Eser, 'Individual Criminal Responsibility' 803; Kai Ambos, ‘Article 25 - Individual Criminal Responsibility' in Otto Triffterer (ed.) Commentary on the Rome Statute of the International Criminal Court: Observers' Notes, Article by Article ( $2^{\text {nd }}$ ed., Hart 2008) 743, 757-759.

${ }^{346}$ Mbarushimana (Decision on the Confirmation of Charges) ICC-01/04-01/10 (16 December 2011) [268]-[292]. See also Ruto, Kosgey, Sang (Decision on the Confirmation of Charges) ICC-01/09-01/11 (23 January 2012) [350]-[354].

${ }^{347}$ See Lubanga Dyilo (Decision on the Confirmation of Charges) ICC-01/04-01/06 (29 January 2007) [337]. 


\subsection{THE PRINCIPLE OF INDIVIDUAL CRIMINAL RESPONSIBILITY}

A significant part of Nuremberg's legacy is the principle of individual criminal responsibility for violations of international law. Article 6 of the Charter of the International Military Tribunal at Nuremberg, signed by the United Kingdom, France, the Union of Soviet Socialist Republics, and the United States and decreed on August 8,1945 , provided for individual criminal responsibility for crimes against peace, war crimes, and crimes against humanity. ${ }^{348}$ It also set out the modes of participation in the crimes prohibited therein:

Leaders, organizers, instigators and accomplices participating in the formulation or execution of a common plan or conspiracy to commit any of the foregoing crimes are responsible for all acts performed by any persons in execution of such plan. ${ }^{349}$

The purpose of criminal law provisions setting out the various modes of participation in crimes is to capture the range of ways that an individual may be culpable in relation to wrongdoing. ${ }^{350}$ The language of this provision reflects the position and status of the defendants as high-ranking members of the Nazi party. Participation in the (a) formulation or execution of a (b) common plan or conspiracy to commit crimes against peace, war crimes, or crimes against humanity gave rise to responsibility for any acts performed in the execution of the plan. ${ }^{351}$ The provision responds to the scale of the atrocities founding prosecutions for war crimes and

\footnotetext{
${ }^{348}$ Art 6 Charter of the International Military Tribunal (Nuremberg) annexed to Agreement for the Prosecution and Punishment of the Major War Criminals of the European Axis (signed in London, 8 August 1945) 82 UNTS 279. See also Judgment of the Nuremberg International Military Tribunal (1 October 1946) (1947) 41 Am. J. Intl L. 172.

${ }^{349}$ Art 6 Nuremberg Charter. See also Art 5(c) Charter of the International Military Tribunal for the Far East (19 January 1946, amended 25 April 1946) TIAS No. 1589.

${ }^{350}$ Boas et al, Forms of Responsibility 2.

${ }^{351}$ The Tribunal ruled that as a separate count the conspiracy charge was applicable only to crimes against peace. Judgment of the Nuremberg IMT 224
} 
crimes against humanity and the nature of crimes against peace as an offence of planning, preparing, and initiating certain conduct.

The scale of the atrocities and nature of the defendants' involvement make it difficult to glean much insight into the operation of complicity in international law from the Nuremberg IMT. ${ }^{352}$ On trial was systematic illegality, and the trial sought to establish the responsibility of the defendants in those terms. Likewise, the further trials carried out under Allied Control Council Order No. 10 were marked by a tendency to consider each defendant's responsibility in general terms. ${ }^{353}$ Although a number of doctrinal insights are evident in the judgments, including some bearing on complicity, ${ }^{354}$ their value is primarily historical and foundational. In respect of the former, the trials contributed greatly to the historical record, producing a mass of documentary and other evidence detailing Nazi criminality. ${ }^{355}$ In respect of the latter, the trials affirmed and developed principles on which international criminal law has been built. ${ }^{356}$

The principle of individual criminal responsibility was reflected in identical terms in the statutes of the International Criminal Tribunals for the former Yugoslavia and Rwanda:

A person who planned, instigated, ordered, committed or otherwise aided and abetted in the planning, preparation or execution of a crime

\footnotetext{
${ }^{352}$ See Kevin Heller, The Nuremberg Military Tribunals and the Origins of International Criminal Law (OUP 2011) 3.

${ }^{353}$ Ibid 252. See also Van Sliedregt, Individual Criminal Responsibility 18-37.

${ }^{354}$ See Robert Wagner \& Six Others (24 July 1946) (1948) III LRTWC 23 (Permanent Military

Tribunal at Strasbourg).

${ }^{355}$ Heller, The Nuremberg Military Tribunals 3-4.

${ }^{356}$ Ibid 3.
} 
referred to in articles 2 to 5 of the present Statute, shall be individually responsible for the crime. ${ }^{357}$

These are the forms of responsibility at the ad hoc tribunals - planners, instigators, orderers, perpetrators, and aiders and abettors bear individual criminal responsibility. The forms of responsibility at the ICTR and ICTY constitute a more sophisticated approach than those at the post-Second World War tribunals. ${ }^{358}$ The Rome Statute takes this development a step further with a detailed and graded approach, setting out the modes of participation in the following way:

3. In accordance with this Statute, a person shall be criminally responsible and liable for punishment for a crime within the jurisdiction of the Court if that person:

(a) Commits such a crime, whether as an individual, jointly with another or through another person, regardless of whether that other person is criminally responsible;

(b) Orders, solicits or induces the commission of such a crime which in fact occurs or is attempted;

(c) For the purpose of facilitating the commission of such a crime, aids, abets or otherwise assists in its commission or its attempted commission, including providing the means for its commission;

(d) In any other way contributes to the commission or attempted commission of such a crime by a group of persons acting with a common purpose. Such contribution shall be intentional and shall either:

(i) Be made with the aim of furthering the criminal activity or criminal purpose of the group, where such activity or purpose involves the commission of a crime within the jurisdiction of the Court; or

(ii) Be made in the knowledge of the intention of the group to commit the crime. ${ }^{359}$

\footnotetext{
${ }^{357}$ Art 7(1) ICTY Statute, Art 6(1) ICTR Statute.

${ }^{358}$ Gerhard Werle, 'General Principles of International Criminal Law' in Antonio Cassese (ed.), Oxford Companion to International Criminal Justice (OUP 2009) 54, 58.

${ }^{359}$ Art 25(3) Rome Statute.
} 
The many ways people participate in wrongdoing will not always fall neatly into one category or another. Moreover, there is interpretive scope to emphasise and expand particular forms of responsibility. For instance, early indications from the ICC suggest that many participants will be brought within the bounds of commission under Article 25(3)(a). ${ }^{360}$ On its face, Article 25(3)(a) encompasses three kinds of perpetrators: individual perpetrators, co-perpetrators, and those who perpetrate through another person. ${ }^{361}$ In each case, the essential characteristic is one of control over the crime. ${ }^{362}$ Individual perpetrators are those who commit a crime by their own hands; they physically perpetrate the crime. ${ }^{363}$ Responsibility for co-perpetration arises when an individual commits a crime jointly with another person. Finally, intermediary or indirect perpetration occurs where a person commits a crime through another person, regardless of whether the latter is criminally responsible. In this last case, the principal — or perpetrator-by-means — uses the actual physical executor as a tool or instrument for the commission. ${ }^{364}$

The use of control over the crime to define principalship denotes the adoption of a normative model of perpetration. ${ }^{365}$ It brings into the ambit of principalship leaders and other superiors who might otherwise have been thought of as orderers, planners, or solicitors. ${ }^{366}$ Responsibility on the basis of co-perpetration will arise where at least two individuals share essential tasks for the concerted purpose of

\footnotetext{
${ }^{360}$ Schabas, A Commentary on the Rome Statute 431.

${ }^{361}$ See Lubanga (Trial Chamber Judgment) ICC-01/04-01/06 (14 March 2012) [977].

${ }^{362}$ Lubanga (Trial Chamber Judgment) [1005]; Lubanga (Decision on the Confirmation of Charges) [326]-[341]; Katanga, Chui (Decision on the Confirmation of Charges) ICC-01/04-01/07 (30 September 2008) [480]-[489].

${ }^{363}$ Eser, 'Individual Criminal Responsibility' 789.

${ }^{364}$ Katanga (Decision on the Confirmation of Charges) [495].

${ }^{365}$ Van Sliedregt, Individual Criminal Responsibility 86.

${ }^{366}$ See Schabas, A Commentary on the Rome Statute 428.
} 
committing a crime, each of them being able to frustrate the commission of the crime by failing to perform her task. ${ }^{367}$ Responsibility on the basis of perpetration-bymeans will arise not only where an innocent or incapable agent is used as a tool by the principal, but also where the principal controls the agent in an organisational context. ${ }^{368}$ Here, international criminal law is attempting to capture within principalship the so-called perpetrator behind the perpetrator, where the tightly controlled and hierarchical apparatus of power is used to secure the indirect perpetrator's wishes. ${ }^{369}$

\subsection{CONCLUSION}

It is clear, then, that the boundaries of different forms of participation may shift. But even with a normative model of principalship, there remains room for complicity as a particular mode of wrongdoing - as a way of participating in the wrongdoing of another actor. As argued in Chapter 2, that mode of wrongdoing is best thought of as comprising two kinds of action: intentionally helping the principal to commit the crime and intentionally influencing the decision of the principal to commit the crime. $^{370}$ The rest of Part B-Chapters 4 and 5-analyses and evaluates the ways in which international criminal law sanctions complicity in the crimes of others.

\footnotetext{
${ }^{367}$ Lubanga (Trial Chamber Judgment) [994]; Lubanga (Decision on the Confirmation of Charges) [342].

${ }^{368}$ Katanga (Decision on the Confirmation of Charges) [500]-[510].

${ }^{369}$ Ibid [514]. See Eser, 'Individual Criminal Responsibility' 795.

${ }^{370}$ Kadish, 'Complicity, Cause and Blame' 342.
} 


\section{CHAPTER 4. PARADIGM DOCTRINES OF COMPLICITY IN INTERNATIONAL CRIMINAL LAW}

\subsection{INTRODUCTION}

Chapter 4 analyses the two paradigm doctrines of complicity in international criminal law: instigation and aiding and abetting. These are the central cases; if asked to explain, in general terms, how international criminal law deals with complicit conduct, the doctrines of instigation and aiding and abetting ought to provide the basis of the answer. It also considers the difficulties caused by the inclusion within the statutes of the ad hoc tribunals of a reference to 'complicity in genocide' as a punishable act. This chapter takes the view that a distinct crime of complicity in genocide is inconsistent with the general structure of international criminal responsibility.

\subsection{INSTIGATION}

The jurisprudence on instigation at the ad hoc tribunals has been relatively settled for some time. ${ }^{371}$ The conduct element of instigation occurs when an individual urges, prompts, or encourages another person to commit a crime. ${ }^{372}$ The mental element is fulfilled where the defendant either (i) acted with the intention that the crime be committed or (ii) was aware of the substantial likelihood that a crime would be committed in the execution of his prompting. ${ }^{373}$ Although it need not be shown that the crime would not have occurred without the prompting of the accused, his actions must be a 'clear contributing factor to the conduct' of the principal. ${ }^{374}$

\footnotetext{
${ }^{371}$ Boas et al, Forms of Responsibility 344.

${ }^{372}$ Semanza (Trial Chamber Judgment) ICTR-97-20-T (15 May 2003) [381].

${ }^{373}$ Kordić, Čerkez (Appeals Chamber Judgment) IT-95-14/2-A (17 December 2004) [29], [32].

${ }^{374}$ Kvočka (Trial Chamber Judgment) IT-98-30/1-T (2 November 2001) [252].
} 
The Rome Statute does not refer specifically to instigation as a form of individual criminal responsibility. Instead, Article 25(3)(b) prohibits solicitation and inducement. Both solicitation and inducement refer to ways that an accomplice may influence a principal's decision to commit a crime. ${ }^{375}$ Black's Law Dictionary defines solicitation as the "criminal offence of urging, advising, commanding or otherwise inciting another to commit a crime. ${ }^{376}$ It defines inducement as the 'act or process of enticing or persuading another person to take a course of action. ${ }^{377}$ As is evident, it is difficult to draw exact lines between the doctrines.

The best approach in this regard is to treat solicitation and inducement under Article 25(3)(b) as broadly synonymous with the doctrine of instigation developed at the ad hoc tribunals. ${ }^{378}$ Inducement does have a sense that the perpetrator was enticed into action, either by the promise of reward or forbearance of sanction. In general, though, Article 25(3)(b) is implicated where a party urges, prompts, or encourages another person to commit a crime. ${ }^{379}$ Drawing on the jurisprudence of the $a d$ hoc tribunals, the inducement or solicitation must be a clear contributing factor to the principal's wrongdoing ${ }^{380}$ and must be allied with at least an awareness of the substantial likelihood that a crime would be committed in the execution of the prompting. $^{381}$

\footnotetext{
${ }^{375}$ Kadish, 'Complicity, Cause and Blame' 343.

${ }^{376}$ Bryan Garner (ed.), Black's Law Dictionary (9 ${ }^{\text {th }}$ ed., West 2009) 1520.

${ }^{377}$ Ibid 845.

${ }^{378}$ Gerhard Werle, 'Individual Criminal Responsibility in Article 25 ICC Statute' (2007) 5 J. Intl Crim. Just. 953, 966-967. See also Schabas, A Commentary on the Rome Statute 432.

${ }^{379}$ Semanza (Trial Chamber Judgment) [381].

${ }^{380}$ Kvočka (Trial Chamber Judgment) [252].

${ }^{381}$ Kordić, Čerkez (Appeals Chamber Judgment) [29], [32].
} 
The Rome Statute's approach to instigation raises interesting questions about the culpability of an instigator vis-à-vis those who provide physical help or assistance to the principal. Article 25(3)(b) establishes criminal responsibility for those who order, solicit, or induce another to commit wrongdoing. As a preliminary matter, immediately evident is the incongruity of the inclusion of ordering in the provision, both with respect to ideas of soliciting and inducing and within the context of the Rome Statute's scheme of culpability as a whole. Soliciting and inducing denote a similar kind of participation - the wrong of persuading another to commit a crime. Ordering does not rest on persuasion, but on command. Moreover, it implicitly demands a relationship of authority between the person giving the order and the primary perpetrator. ${ }^{382}$

It is doubtful that the inclusion of ordering within Article 25(3)(b) fits with the culpability scheme of Article 25. This scheme attempts to grade different forms of responsibility from most serious to least. ${ }^{383}$ Those who order their subordinates to commit crimes are at least as culpable as, if not more culpable than, those who pull the trigger. ${ }^{384}$ The Rome Statute itself recognises this in the inclusion of indirect perpetration in Article 25(3)(a). In its Decision on the Confirmation of Charges in Katanga, the ICC Pre-Trial Chamber sought to distinguish 'ordinary cases of criminal ordering' under Article 25(3)(b) from intermediary perpetration through ordering under Article 25(3)(a). For the court, the difference lay in the notion of 'automatic compliance' in a hierarchical organisation in the latter case. ${ }^{385}$

\footnotetext{
${ }^{382}$ Eser, 'Individual Criminal Responsibility' 796.

${ }^{383}$ Werle, 'Individual Criminal Responsibility' 957; Eser, 'Individual Criminal Responsibility’ 797. See though Ch. 4.4.1 below.

${ }^{384}$ See Eser, 'Individual Criminal Responsibility' 796.

${ }^{385}$ Katanga (Decision on the Confirmation of Charges) [517].
} 
It remains to be seen how these two forms of ordering will develop in the case law. Two points may be made at this stage. First, so-called 'ordinary cases of criminal ordering' still imply at least an equivalent, if not greater, level of culpability to physical perpetration under Article 25(3)(a). Secondly, there is interpretive room within the idea of commission 'through another person' in the text of Article 25(3)(a) to accommodate most cases where a superior issues an order to a subordinate to commit a crime. ${ }^{386}$ This would leave Article 25(3)(b) to address solicitation and inducement, or instigation, a classic form of complicity.

Other than the incongruity of ordering, a second noticeable aspect to Article $25(3)(b)$ is the heightened culpability of instigators vis-à-vis both those who provide physical assistance and ordinary abettors under Article 25(3)(c). With respect to ordinary abettors, there is substantial overlap in the conduct that each seeks to prohibit. $^{387}$ The difference between the two was addressed by the ICTY in Orić. According to the Trial Chamber, instigation does not require that the criminal idea originated with the instigator but that the decision of the perpetrator to commit the crime was 'brought about by persuasion or strong encouragement' by the instigator. ${ }^{388}$ Another way to put this is that instigation 'means to evoke another person's intent to commit an offence. ${ }^{389}$ Where the principal perpetrator has already decided to commit the crime, encouragement or moral support will not constitute instigation but

\footnotetext{
${ }^{386}$ See Ambos, 'Article 25' 747-752; Eser, 'Individual Criminal Responsibility' 797.

${ }^{387}$ Schabas, A Commentary on the Rome Statute 434.

${ }^{388}$ Orić (Trial Chamber Judgment) IT-03-68-T (30 June 2006) [271].

${ }^{389}$ Foster \& Sule, German Legal System and Laws 375
} 
may give rise to aiding and abetting liability. ${ }^{390}$ Such a conviction would turn, of course, on the fulfillment of the nexus requirement.

Thus instigation may be thought of as a more serious form of complicity than simple abetment, distinguished by the strength of the influence. Under the Rome Statute, it also denotes a more serious form of responsibility than the provision of help. ${ }^{391}$ This approach denies a singular conception of complicity liability that encompasses the ways that an accomplice may participate in wrongdoing. In doing so, it echoes the approach of the German Criminal Code. Under StGB § 26, instigators are punished to the extent of the principal's liability. ${ }^{392}$ Under StGB $\S 27$, the prohibition on the provision of aid, the aider's sentence may be mitigated pursuant to Section 49 of the Code. ${ }^{393}$ This distinction makes sense. Once a principal makes up his mind to commit the crime, the exact manner of commission, in many cases, is just a matter of details. Influencing the decision of the perpetrator to commit the crime in the first place does entail a closer connection to the wrong than simply helping along the way.

\subsection{AIDING AND ABETTING}

\subsubsection{The Conduct Element}

The second archetypal form of complicity in international criminal law is aiding and abetting. ${ }^{394}$ Even though it is sometimes considered as a unitary doctrine, the terms

\footnotetext{
${ }^{390}$ Ibid.

${ }^{391}$ Werle, 'Individual Criminal Responsibility' 957. See though Ch. 4.4.1 below.

${ }^{392} \mathrm{StGB} \S 26$.

${ }^{393} \mathrm{StGB} \S 27,49(1)(2)$.

${ }^{394}$ Eser, 'Individual Criminal Responsibility' 798; Schabas, A Commentary on the Rome Statute 433 434.
} 
mirror Kadish's distinction between helping the primary perpetrator to commit the crime and influencing his decision to do so. ${ }^{395}$ At the ad hoc tribunals, the conduct element of aiding and abetting liability is formulated to comprise 'acts specifically directed to assist, encourage or lend moral support to the perpetration' of the crime. ${ }^{396}$ The formulation 'assist, encourage or lend moral support' reflects customary international law. ${ }^{397}$ Article 25(3)(c) of the Rome Statute refers to those who aid, abet or otherwise assist in the commission or attempted commission of crime, and specifically includes the provision of means for the commission of crime. ${ }^{398}$ The phrasing of the provision suggests that aiding and abetting are subsets of a wider category of assistance. $^{399}$ Too much time should not be spent on trying to explicitly delineate the meaning of each- 'exchanging synonyms' is not helpful. ${ }^{400}$ Instead, it is likely that the ICC will look to the ad hoc tribunals' jurisprudence on this issue.

Assistance, often termed 'practical' assistance by the tribunals, ${ }^{401}$ is relatively straightforward, and encompasses the range of conduct envisaged in Kadish's category of helping the principal to commit crime. ${ }^{402}$ Examples are the provision of weapons, transport, or information concerning the location of the potential victims to the principal perpetrator. ${ }^{403}$ One complication has been added by the recent decision

\footnotetext{
${ }^{395}$ Kadish, 'Complicity, Cause and Blame' 342. See Mrkšić et al (Trial Chamber Judgment) [551]; Schabas, A Commentary on the Rome Statute 434.

${ }^{396}$ Tadić (Appeals Chamber Judgment) [229].

${ }^{397}$ See Prosecutor v Taylor (Appeals Chamber Judgment) SCSL-03-01-A (26 September 2013) [362].

${ }^{398}$ Art 25(3)(c) Rome Statute.

${ }^{399}$ Eser, 'Individual Criminal Responsibility' 798.

${ }^{400}$ Ibid 799.

${ }^{401}$ See e.g. Blaškić (Appeals Chamber Judgment) [46].

${ }^{402}$ Kadish, 'Complicity Cause and Blame' 345.

${ }^{403}$ See e.g. Ntakirutimana, Ntakirutimana (Appeals Chamber Judgment) ICTR-96-10-A \& ICTR-9617-A (13 December 2004) [530], [532].
} 
of the Appeals Chamber of the ICTY in Perišić. ${ }^{404}$ As noted above, formally the test for aiding and abetting refers to 'acts specifically directed to assist, encourage or lend moral support to the perpetration. ${ }^{405}$ This language, initially set out in Tadić, had previously been repeated in various judgments without any suggestion that the idea of a specifically directed act adds anything to the doctrinal requirements of the test. ${ }^{406}$ In Perišić, however, the Appeals Chamber overturned the appellant's convictions for aiding and abetting crimes committed by the Army of the Republika Srpska in Sarajevo and Srebrenica. The basis for the reversal was the Trial Chamber's failure to require that Perišić's actions 'were specifically directed to aid and abet' the principal crimes. $^{407}$

The Appeals Chamber's decision is indefensible, drawing 'a series of untenable distinctions at the level of actus reus. ${ }^{408}$ Specifically, it attempts to resolve in the conduct element two questions arising at other points of any complicity enquiry. First, complicity requires a relationship between the accomplice's acts and the principal's wrong to give it any meaningful content. ${ }^{409}$ This was termed the nexus element in the analytical framework set out in Chapter 2. In international criminal law, the nexus element is expressed as a standard of substantial effect or substantial contribution. ${ }^{410}$ The Appeals Chamber's standard of specific direction threatens to introduce an unnecessary limiting criterion into the conduct element where that role is

\footnotetext{
${ }^{404}$ Perišić (Appeals Chamber Judgment) IT-04-81-A (28 February 2013).

${ }^{405}$ Tadić (Appeals Chamber Judgment) [229] (emphasis added).

${ }^{406}$ James Stewart, 'The ICTY Loses its Way on Complicity - Part 1' (Opinio Juris, 3 April 2013) http://opiniojuris.org/2013/04/03/guest-post-the-icty-loses-its-way-on-complicity-part-1/> accessed 23 July 2013. See also Perišić (Appeals Chamber Judgment) (Partially Dissenting Opinion of Judge Liu).

${ }^{407}$ Perišić (Appeals Chamber Judgment) [43].

${ }^{408}$ Stewart, 'The ICTY Loses its Way on Complicity - Part 1.'

${ }^{409}$ See Ch. 2.5.3 above.

${ }^{410}$ See Ch. 4.3.2 below.
} 
already played by another limb of the test for aiding and abetting. ${ }^{411}$ Second, although the Appeals Chamber asserts that 'specific direction is an analytically distinct element of actus reus, ${ }^{, 412}$ it is really saying something about the mental state with which Perišić provided his assistance. ${ }^{413}$ No doubt, difficult questions arise in respect of the mental element of complicity. ${ }^{414}$ These issues should not be evaded by introducing a new, analytically incoherent standard into the conduct element.

In any event, the additional requirement of specific direction set out in Perišić is inconsistent with customary international law. ${ }^{415}$ In its decision in Taylor, the Appeals Chamber of the Special Court for Sierra Leone explicitly rejected the argument that specific direction forms part of the actus reus of aiding and abetting liability in customary international law. ${ }^{416}$ This holding is consistent with postSecond World War jurisprudence ${ }^{417}$ and the majority of case law at the ad hoc tribunals. $^{418}$ It is also correct as a matter of principle.

Returning to the ICTY's general test, encouragement and the provision of moral support fall into Kadish's second category: influencing the decision of the

\footnotetext{
${ }^{411}$ Stewart, 'The ICTY Loses its Way on Complicity - Part 1.'

${ }^{412}$ Perišić (Appeals Chamber Judgment) [48].

${ }^{413}$ See James Stewart 'The ICTY Loses its Way on Complicity - Part 2' (Opinio Juris, 3 April 2013) http://opiniojuris.org/2013/04/03/guest-post-the-icty-loses-its-way-on-complicity-part-2/> accessed 23 July 2013. See also Perišić (Appeals Chamber Judgment) (Joint Separate Opinion of Judges Meron and Agius; Partially Dissenting Opinion of Judge Liu).

${ }^{414}$ See Ch. 4.3 .3 below.

${ }^{415}$ Prosecutor v Taylor (Appeals Chamber Judgment) [481]. See James Stewart, "'Specific Direction” is Unprecedented: Results from Two Empirical Studies' (EJIL:Talk!, 4 September 2013)

$<$ http://www.ejiltalk.org/specific-direction-is-unprecedented-results-from-two-empirical-studies/> accessed 23 September 2013.

${ }^{416}$ Prosecutor v Taylor (Appeals Chamber Judgment) [481].

${ }^{417}$ See e.g. Zyklon B - Trial of Bruno Tesch and Two Others (8 March 1946) (1947) I LRTWC 93.

${ }^{418}$ See Stewart, 'Specific Direction is Unprecedented'; Prosecutor v Taylor (Appeals Chamber Judgment) [471]-[481].
} 
principal to commit the crime. ${ }^{419}$ Statements of support, cheering, or applause will suffice, ${ }^{420}$ remembering that graver forms of influence will be captured within the doctrine of instigation. Beyond outward expressions of encouragement, more difficult questions arise. One is whether liability for aiding and abetting may be founded on an individual's mere presence at the scene of the crime. In Furundžija, the Trial Chamber examined a long line of cases arising out of World War II. As a baseline, it found that presence alone was not sufficient to give rise to liability. ${ }^{421}$ This is consistent with a long held common law position. ${ }^{422}$ However, where the defendant's presence had a 'significant legitimising or encouraging effect on the principal' responsibility may arise. ${ }^{423}$ This is most often the case where the spectator occupies a position of authority vis-à-vis the principal perpetrator.

Exact formulations of the test for liability of the approving spectator have differed in judgments of the tribunals. A summation may be found in the judgment of the Appeals Chamber of the ICTY in Brđanin. Describing the situations where such conduct may amount to tacit approval or encouragement, the Appeals Chamber stated:

In the cases where this category was applied, the accused held a position of authority, he was physically present [at] the scene of the crime, and his non-intervention was seen as tacit approval and encouragement. $^{424}$

\footnotetext{
${ }^{419}$ Kadish, 'Complicity, Cause and Blame' 342-344.

${ }^{420}$ See Wilcox $v$ Jeffery [1951] 1 All ER 464; $R v$ Giannetto [1997] 1 Cr. App. R. 1. See also Ashworth, Principles of Criminal Law 408.

${ }^{421}$ Furundžija (Trial Chamber Judgment) IT-95-17/1-T (10 December 1998) [232].

${ }^{422}$ Smith, A Treatise on Complicity 35-39.

${ }^{423}$ Furundžija (Trial Chamber Judgment) [232].

${ }^{424}$ Brđanin (Appeals Chamber Judgment) IT-99-36-A (3 April 2007) [273].
} 
Although liability does not follow automatically on this basis where a superior officer is present at the scene of the crime, presence is 'an important indicium of encouragement or support. ${ }^{425}$ In the case of Akayesu at the ICTR, the defendant's status as mayor of the Taba commune and presence at the scene of the crimes 'sent a clear signal of official tolerance for sexual violence. ${ }^{426}$ Cases of this kind will give rise to aiding and abetting liability.

It is also possible that the category of the approving spectator encompasses situations other than those of a superior present at the scene of the subordinate principal's crime. A line of British cases suggests that in cases of non-accidental and continuing presence, liability may arise in the absence of any positive act where a spectator intended to encourage the principal and in fact did so. ${ }^{427}$ This does not overly stretch the conceptual limits of the ICTY's holding in Brđanin. Brđanin and its antecedents establish that an inference of encouragement may be drawn from the defendant's status. ${ }^{428}$ Although this is the most likely basis of the inference, it need not be seen as the only one. In situations where it becomes clear that the principal is deriving substantial encouragement from the spectator's presence, and it can be shown that such encouragement was intended, liability for aiding and abetting should arise. $^{429}$ As explained in the next section, the crucial point, in this respect, is the demonstration of substantial effect.

\footnotetext{
${ }^{425}$ Brđanin (Trial Chamber Judgment) IT-99-36-T (1 September 2004) [271]. See also Boas et al, Forms of Responsibility 308-310.

${ }^{426}$ Akayesu (Trial Chamber Judgment) ICTR-96-4-T (2 September 1998) [693].

${ }^{427}$ Coney (1882) 8 QBD 534; $R$ v Clarkson (1971) 55 Cr. App. Rep. 445.

${ }^{428}$ Brđanin (Appeals Chamber Judgment) [273]; Akayesu (Trial Chamber Judgment) [693]; Aleksovski (Trial Chamber Judgment) IT-95-14/1-T (25 June 1999) [65]; Blaškić (Trial Chamber Judgment) IT95-14-T (3 March 2000) [284].

${ }^{429}$ See Smith, A Treatise on Complicity 35-39.
} 


\subsubsection{The Nexus Requirement}

The range of conduct that might help or encourage a principal's commission of crime is broad. Complicity rules ordinarily, and ought to, specify a minimum relationship between the accomplice's actions and the principal's crime. ${ }^{430}$ International criminal law is no different. The ad hoc tribunals have held that the acts of assistance, encouragement, or support must have a substantial effect on the commission of the crime to attract liability for complicity. ${ }^{431}$ This reflects customary international law. ${ }^{432}$ The standard has also been expressed as one of substantial contribution, ${ }^{433}$ though it is doubtful that this differs in a material respect from the standard of substantial effect. ${ }^{434}$ Indeed, in Mrkšić, the ICTY Appeals Chamber articulated both tests in the same paragraph. ${ }^{435}$ Substantial effect requires neither a cause-effect relationship between the assistance and the commission nor that the assistance was a condition-precedent thereto. ${ }^{436}$ Permitting resources under one's control to be used for the perpetration of crime, guarding detainees, and controlling access to them are examples of conduct that may have a substantial effect on the principal's perpetration. ${ }^{437}$ It is likely that a similar test will be adopted at the ICC. ${ }^{438}$

\footnotetext{
${ }^{430}$ See Ch. 2.5.3 above.

${ }^{431}$ Tadić (Appeals Chamber Judgment) [229]; Simić (Appeals Chamber Judgment) [85]; Mrkšić, Šljivančanin (Appeals Chamber Judgment) [81].

${ }^{432}$ Prosecutor v Taylor (Appeals Chamber Judgment) [401].

${ }^{433}$ See e.g. Krstić (Trial Chamber Judgment) IT-98-33-T (2 August 2001) [601]; Mrkšić, Šljivančanin (Appeals Chamber Judgment) [81].

${ }^{434}$ Boas et al, Forms of Responsibility 317.

${ }^{435}$ Mrkšić, Šljivančanin (Appeals Chamber Judgment) [81].

${ }^{436}$ Blaškić (Appeals Chamber Judgment) [48].

${ }^{437}$ Krstić (Appeals Chamber Judgment) IT-98-33-A (19 April 2004) [135]-[138]; Blagojević, Jokić (Appeals Chamber Judgment) IT-02-60-A (9 May 2007) [132].

${ }^{438}$ See Eser, 'Individual Criminal Responsibility' 799-801; Ambos, 'Article 25' 754-756.
} 
In determining what constitutes a 'substantial effect', it is helpful to distinguish different forms of aiding and abetting. Some forms of assistance may substantially contribute to the perpetration of crime without the principal being aware thereof. ${ }^{439}$ The $19^{\text {th }}$ century case of State $v$ Tally provides an example. Tally, a judge, prevented the transmission of a telegram intended to warn one Ross that Tally's brothers-in-law were out to kill him. ${ }^{440}$ The brothers-in-law did not know of this assistance when they perpetrated the crime. Nonetheless, Tally was convicted as an accomplice.

Other forms of complicity, specifically those of encouragement or moral support, logically require actual communication to the principal. Shouts of encouragement that go unheard cannot be considered substantial assistance. ${ }^{441}$ Such conduct does not influence the perpetrator in any way. As a theoretical matter, extending aiding and abetting liability to include failed attempts at complicity links the complicit actor to conduct to which his actions bear no relation at all. In Fletcher's words, '[t]hat the accessory actually contributes to the commission of the crime is part of what it means to be an accessory. ${ }^{, 442}$

One notable aspect of the criterion of substantial effect at the ad hoc tribunals is its breadth. ${ }^{443}$ The tribunals have repeatedly emphasised what substantial effect does not require - a cause-effect or condition precedent relationship - but have not spent as much time setting out what it does require. Any form of support, even tacit

\footnotetext{
${ }^{439}$ Fletcher, Rethinking Criminal Law 678.

${ }^{440}$ State v Tally (1894) 15 So 722.

${ }^{441}$ Fletcher, Rethinking Criminal Law 680.

${ }^{442}$ See Fletcher, Rethinking Criminal Law 680.

${ }^{443}$ Werle, 'Individual Criminal Responsibility’ 968.
} 
approval arising on the basis of mere presence, seems to fulfill the nexus requirement. ${ }^{444}$ As a basic matter of interpretation, substantial effect must mean something more than simply an effect, or a remote effect. Moreover, given the potential breadth of the objective requirement of aiding and abetting, ${ }^{445}$ the nexus requirement ought to play a limiting role in excluding more minor contributions. ${ }^{446}$ Some forms of encouragement, including many cases of the approving spectator, should probably be insufficient for accomplice liability.

There is also a temporal aspect to the nexus requirement. It is often emphasised in the jurisprudence of the ad hoc tribunals that the assistance may be rendered before, during, or after the principal has committed the crime. ${ }^{447}$ Liability for assistance rendered before or during the crime is uncomplicated. In the Čelebići case, the Appeals Chamber adopted the Trial Chamber's holding that the act of assistance may occur at a time and place removed from the commission of the crime so long as it is 'found to have contributed to, or have had an effect on,' its commission. ${ }^{448}$ Evidently, in cases of ex post facto assistance, much of the legwork will be done in proving the substantial effect of the assistance.

The cases of Strugar and Blagojević illustrate this point. In Strugar, the Trial Chamber rejected the prosecution's argument that the defendant's failure to properly

\footnotetext{
${ }^{444}$ See e.g. Brđanin (Appeals Chamber Judgment) [273].

${ }^{445}$ See e.g. Tadić (Trial Chamber Judgment) IT-94-1-T (7 May 1997) [689]: 'The Trial Chamber finds that aiding and abetting includes all acts of assistance by words or acts that lend encouragement or support, as long as the requisite intent is present.'

${ }^{446}$ See Eser, 'Individual Criminal Responsibility' 800-801.

${ }^{447}$ See e.g. Mrkšić, Šljivančanin (Appeals Chamber Judgment) [81]; Blagojević, Jokić (Appeals Chamber Judgment) [127]; Simić (Appeals Chamber Judgment) [85].

${ }^{448}$ Čelebići (Appeals Chamber Judgment) IT-96-21-A (20 February 2001) [352].
} 
investigate and punish the unlawful conduct of his subordinates could constitute ex post facto assistance having a substantial effect on the commission of those crimes. ${ }^{449}$ In Blagojević, one issue was whether the reburial of victims of the genocide at Srebrenica carried out with the defendant's assistance could constitute ex post facto aiding and abetting in the commission of that crime. Answering affirmatively, the Trial Chamber found that such assistance could be ex post facto aiding and abetting. However, it found that liability could only arise in such a case where there was a prior agreement between the principal and ex post facto assister that the accomplice would provide assistance. ${ }^{450}$ This was not the case in Blagojević.

These cases demonstrate the limited reach of ex post facto aiding and abetting. The phrasing often adopted by the tribunals should not be read to suggest that international criminal law recognises complicity liability on the basis of an individual's conduct as an accessory after the fact. As discussed in Chapter 2, despite linguistic similarities, the doctrine of accessory after the fact should not be regarded as a form of complicity. ${ }^{451}$ As Blackstone put it, the crime of accessory after the fact was 'always an offence of a different species of guilt... ${ }^{452}$ It is not that the subsequent assister contributed to the commission of the crime, but that she receives, relieves, or comforts the wrongdoer in the knowledge of its commission. ${ }^{453}$ This distinction is generally adhered to in national legal systems. ${ }^{454}$

\footnotetext{
${ }^{449}$ Strugar (Trial Chamber Judgment) IT-01-42-T (31 January 2005) [355].

${ }^{450}$ Blagojević, Jokić (Trial Chamber Judgment) IT-02-60-T (17 January 2005) [730]-[731]. The line between cases of this kind and joint criminal enterprise liability is not altogether clear.

${ }^{451}$ Smith, A Treatise on Complicity 7. See Ch. 2.2 above.

452 Bl Comm 40.

453 Ibid 37.

${ }^{454}$ William Schabas, The UN International Criminal Tribunals - The Former Yugoslavia, Rwanda and Sierra Leone (CUP 2006) 305.
} 
For this reason, care should be taken in simply asserting that the assistance rendered by an aider or abettor may occur before, during, or after the commission of the crime. The requirement of a substantial contribution to perpetration is essential. This requirement is manifest in the ad hoc tribunals' demand that 'prior agreement exists between the principal and person who subsequently aids and abets in the commission of the crime ${ }^{, 455}$ To put it in practical terms, if the principal and aider agree that the principal will murder a civilian and the aider will dispose of the body, criminal liability for aiding and abetting murder may arise. ${ }^{456}$ If the principal kills a civilian, and another party, with no prior knowledge of the murder, agrees to dispose of the body, no accomplice liability arises. The other party may be liable for some other crime, perhaps obstruction of justice, but is not in a legal sense complicit in the murder.

\subsubsection{The Mental Element}

The range of conduct that might fulfill the conduct element of aiding and abetting liability is broad. In addition, the nexus requirement remains underdeveloped in international criminal law. This shifts much of the burden in delimiting liability to the fault of the accomplice. At the ad hoc tribunals, the mens rea requirement has been formulated in different terms. ${ }^{457}$ For the most part, the standard is now clear: the aider and abettor must know or be aware that his conduct assists in the commission of the crime of the principal perpetrator. ${ }^{458}$ It is not required that his purpose was to

\footnotetext{
${ }^{455}$ Blagojević, Jokić (Trial Chamber Judgment) [731].

${ }^{456}$ Again, there is a possibility that cases of this kind will give rise to joint criminal enterprise liability.

${ }^{457}$ Boas et al, Forms of Responsibility 319-320.

${ }^{458}$ Blaškić (Appeals Chamber Judgment) [49]; Orić (Appeals Chamber Judgment) [43].
} 
provide assistance. ${ }^{459}$ The best formulation is probably that of the Trial Chamber in Kunarac: the aider and abettor must 'take the conscious decision to act in the knowledge that he thereby supports the commission of the crime. ${ }^{460}$

Exactly what the aider and abettor must know has been a matter of controversy. A number of trial and appeals chambers have put forward, often in the same breath, the following two requirements: (A) the aider and abettor must be 'aware of the essential elements of the crime which was ultimately committed by the principal'; ${ }^{461}$ and $(\mathrm{B})$ the aider and abettor need only know that one of a number of crimes will probably be committed, and one of those crimes is, in fact committed; he need not know 'either the precise crime that was intended or the one that was, in the event, committed. ${ }^{462}$ One argument is that it would be appropriate to resolve the supposed conflict against the prosecution; that is, requiring that the accused was aware of the specific crime of the principal to which he rendered assistance. ${ }^{463}$ This reads out entirely the repeated assertions set out in (B) above.

Part of the difficulty here arises from the complex interplay between the knowledge of the aider, the intention of the principal, and the eventual commission of crime. In the typical case, the requirement in (A) will be sufficient to resolve the matter - the accomplice renders assistance in the knowledge that the principal intends

\footnotetext{
${ }^{459}$ See Blaškić (Appeals Chamber Judgment) [49].

${ }^{460}$ Kunarac, Kovač, Vuković (Trial Chamber Judgment) IT-96-23-T \& IT-96-23/1-T (22 February 2001) [392]. See Boas et al, Forms of Responsibility 321.

${ }^{461}$ See Haradinaj et al (Appeals Chamber Judgment) [58]; Orić (Appeals Chamber Judgment) [43]; Mrkšić, Šljivančanin (Appeals Chamber Judgment) [159]; Simić (Appeals Chamber Judgment) [86].

${ }^{462}$ See Haradinaj et al (Appeals Chamber Judgment) [58]; Mrkšić, Šljivančanin (Appeals Chamber Judgment) [159]; Simić (Appeals Chamber Judgment) [86].

${ }^{463}$ Boas et al, Forms of Responsibility 323-324.
} 
to commit a specific crime. Outside the central case, (B) should be read as an exceptional qualification of the general principle in (A). Imagine a soldier delivers a prisoner of war to a detention centre manned by paramilitaries in the knowledge that the paramilitaries routinely mistreat, torture, and/or kill detainees. The soldier may not know if the detainee will, in that particular instance, be tortured before being killed, tortured and released, mistreated and released, or immediately killed. If the soldier knew that it was probable that one of these crimes would be committed and, in fact, one of them is committed, he should be seen to fulfill the mens rea requirement of aiding and abetting liability. If the crime that occurs is not one of the number of crimes that the soldier thought would probably occur, there should be no aiding and abetting liability. This test echoes Lord Scarman's approach in Maxwell. ${ }^{464}$

James Stewart argues that 'awareness of a probability is constitutive of culpable risk-taking, not knowledge. ${ }^{465}$ In these instances, the conventional notion of knowledge does not sit easily with the interaction between the accomplice and principal. ${ }^{466}$ Here, at least, the standard of knowledge is taken to encompass what looks like a heightened form of recklessness. ${ }^{467}$ This standard - that the aider knows that the crime will probably be committed - is particularly important in the context of culpable omissions. Here, the focus will be on the defendant's failure to act in the knowledge that the specified harm would in 'likelihood' eventuate. ${ }^{468}$ The determination of the accused's mens rea will often involve a detailed evidentiary

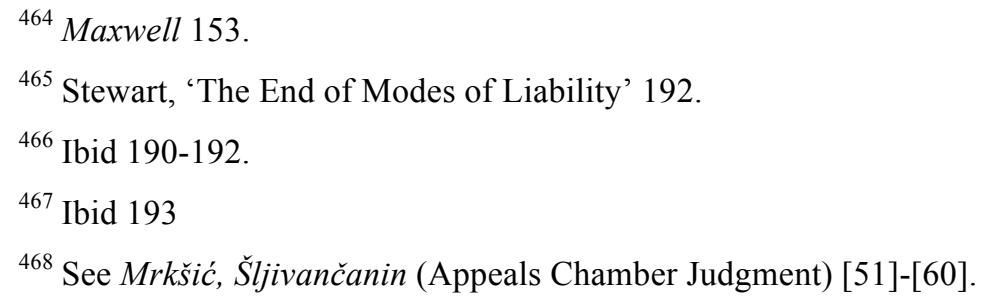


inquiry during which the tribunal draws inferences from various events and statements prior to, and during, the commission of the crime. ${ }^{469}$

More generally, though, at the ad hoc tribunals the true purpose debate is resolved in favour of a standard of knowledge. This is consistent with customary international law. ${ }^{470}$ For instance, in the Zyklon $B$ case before the British Military Tribunal in Hamburg, Bruno Tesch and Karl Weinbacher were convicted of war crimes on the basis of their provision of poison gas to the S.S. that was used at Auschwitz. ${ }^{471}$ As summarised by the Judge Advocate, what needed to be demonstrated was 'that the accused knew that the gas was to be used for the purpose of killing human beings. ${ }^{472}$

Interestingly, the Rome Statute takes the opposite approach. Article 25(3)(c) requires that the assistance be given 'for the purpose of facilitating the commission' of the crime. ${ }^{473}$ The provision of a specific mental element ousts the applicability of the default rule in Article 30. ${ }^{474}$ Aiding and abetting under the Rome Statute thus requires a demonstration of purpose. ${ }^{475}$ This stricter mental element will be of less relevance to cases of abetment as the accomplice's purpose will usually be easily inferred from the nature of the speech. ${ }^{476}$ In cases of physical assistance, it may be

\footnotetext{
${ }^{469}$ See e.g. Blagojević, Jokić (Appeals Chamber Judgment) [143]-[176].

${ }^{470}$ For an overview, see Prosecutor v Taylor (Appeals Chamber Judgment) [413]-[437]; Presbytarian Church of Sudan et al v Talisman Energy, Inc. (No. 09-1262) (Brief of Amici Curiae of International Law Scholars). See also Van Sliedregt, Individual Criminal Responsibility 128-130.

${ }^{471}$ Zyklon B - Trial of Bruno Tesch and Two Others (8 March 1946) (1947) I LRTWC 93.

${ }^{472}$ Ibid 101.

${ }^{473}$ Though see Art 25(3)(d)(ii) Rome Statute.

${ }^{474}$ Art 30 Rome Statute.

${ }^{475}$ Schabas, A Commentary on the Rome Statute 435.

${ }^{476}$ Ibid 436.
} 
decisive. Eser gives the example of a person asked by a soldier to disclose the whereabouts of a civilian, who is later killed. If the person assisted out of fear rather than out of an intention to assist in the unlawful killing of a civilian, he would not be liable under Article 25(3)(c), even though he is aware that he would be helping the perpetrator. $^{477}$ This logic may absolve the independent shopkeeper who, purely in pursuit of profit, knowingly provides the means for the commission of crime.

Related to the knowledge/purpose debate is the wider question of how international criminal law doctrines of complicity, premised to some degree on individualised connections between accomplice and principal, can deal with largescale provisions of aid to groups or collections of actors. This wider question arose in the Perišić acquittal, noted above, and often features in debates about the arming of rebel groups, most recently those engaged in hostilities in Syria. ${ }^{478}$ To take Syria specifically, there is strong evidence that some of the rebels have committed international crimes. ${ }^{479}$ It seems probable that in the ongoing course of hostilities, more crimes will be committed. Yet, the debate about providing arms and other assistance persists.

This issue is not localised to Syria. ${ }^{480}$ More generally, whenever we consider large-scale assistance to a group or collection of actors who carry out a mix of lawful

\footnotetext{
${ }^{477}$ Eser, 'Individual Criminal Responsibility' 801.

${ }^{478}$ Perišić (Appeals Chamber Judgment).

${ }^{479}$ See e.g. UNHRC, 'Report of the Independent International Commission of Inquiry on the Syrian Arab Republic' (4 June 2013) UN Doc. A/HRC/23/58; Human Rights Watch, 'Open Letter to the Leaders of the Syrian Opposition' (20 March, 2012).

${ }^{480}$ There is a risk of becoming bogged down in the factual peculiarities of a single case, a risk amplified by somewhat shaky knowledge as to exactly what is happening at this moment in Syria.
} 
and unlawful activities, difficult questions arise for complicity. ${ }^{481}$ By introducing the requirement of specific direction into the conduct element, the ICTY Appeals

Chamber in Perišić attempted to evade these difficult questions by simply absolving potentially culpable participants. It attempted to re-resolve the knowledge/purpose debate in favor of a standard that looks like purpose, albeit smuggled into the actus reus. ${ }^{482}$ Other than analytical incoherence and inconsistency with customary international law, ${ }^{483}$ this approach threatens to leave aiding and abetting liability under-inclusive, potentially allowing knowing accomplices a defence that they were simply out to make a profit or pursue some independent objective, not to direct their assistance towards the commission of the crime.

There is no easy answer here. In part, the ordinary requirements of complicity liability, particularly the nexus requirement, will exclude some cases of large-scale assistance. ${ }^{484}$ As the probability that some of that aid will be used to commit international crimes increases, so the burden should fall on the potentially complicit party to either refrain from providing aid or do more to ensure that its assistance does not substantially contribute to the commission of international crimes. The generic idea of 'arming the rebels' obscures a raft of choices therein: who exactly is armed, with what, on what conditions, with what kinds of training. That there are good strategic, policy, or even humanitarian reasons for supporting one side to a conflict should not render inapplicable ordinary doctrines of complicity.

\footnotetext{
${ }^{481}$ See Jens Ohlin, 'Why did the ICTY Acquit Stanišić and Simatović?' (Lieber Code, 1 June 2013) $<$ http://www.liebercode.org/2013/06/why-did-icty-acquit-stanisic-and.html> accessed 23 July 2013. Juris, 12 June 2013) < http://opiniojuris.org/2013/06/12/specific-direction-is-indefensible-a-responseto-heller-on-complicity/> accessed 23 July 2013.
} 
The mental element of accomplice liability also raises a difficult question in the context of specific intent crimes. The case law of the tribunals is clear that knowledge of the principal's specific intent is sufficient. ${ }^{485}$ So for persecutions, for instance, assistance must be provided with awareness of the discriminatory grounds of the perpetrator's conduct. ${ }^{486}$ For genocide, the assistance must be provided with awareness of the perpetrator's intent to destroy, in whole or in part, a national, ethnical, racial, or religious group, as such. ${ }^{487}$ Some scholars, however, argue that accomplices should share the intent of the principal. In respect of genocide, for instance, Mettraux argues that a knowledge standard is not only incorrect as a matter of law but also, in the undue pursuit of convictions, risks depriving genocide of its specificity and identity as the most serious crime in international criminal law. ${ }^{488}$ On his interpretation, accomplices should also hold the intent to destroy the protected group.

Mettraux's argument is not persuasive. ${ }^{489}$ Imagine a developer wishes to build a power station in a region heavily populated by a particular racial minority. $\mathrm{He}$ knows that a paramilitary group is planning to commit genocide against the group so decides to provide them with funds and logistical support. The developer bears no genocidal intent towards the racial minority; that is to say, in providing the support he

\footnotetext{
${ }^{485}$ See Krstić (Appeals Chamber Judgment) [140]; Blagojević, Jokić (Appeals Chamber Judgment) [127]; Ntakirutimana, Ntakirutimana (Appeals Chamber Judgment) [364].

${ }^{486}$ See generally Tadić (Appeals Chamber Judgment) [305]; Ken Roberts, 'The Law of Persecution Before the International Criminal Tribunal for the Former Yugoslavia’ (2002) 15 Leiden J. Intl L. 623.

${ }^{487}$ For a discussion of the intent required for genocide, see Alexander Greenawalt, 'Rethinking Genocidal Intent: The Case for a Knowledge-Based Interpretation' (1999) 99 Colum. L. Rev. 2259; Kai Ambos, 'What Does “Intent to Destroy" in Genocide Mean?' (2009) 91 Intl Rev. of the Red Cross 833.

${ }^{488}$ Guénaël Mettraux, International Crimes and the Ad Hoc Tribunals (OUP 2005) 212.

${ }^{489}$ See Werle, 'Individual Criminal Responsibility’ 969.
} 
does not 'seek to produce' the destruction of the group. ${ }^{490}$ In fact, his own intent is directed to forcible displacement of the group, rather than its destruction. ${ }^{491}$ The developer knows, however, of the group's genocidal plans. ${ }^{492}$ Assuming genocide is committed, on Mettraux's interpretation he would not be guilty of aiding and abetting genocide.

Such an outcome would be wrong. In essence, complicity liability is about helping or influencing the commission of wrongdoing by another party. As Werle puts it, 'it is not the person assisting who defines the crime committed; it is the perpetrator. ${ }^{493}$ The accomplice need not carry out any part of the conduct element of the offence and, likewise, should not be required to share the mental element. At the tribunals, and in customary international law, knowing assistance or influence is sufficient to render the provider an accomplice.

\subsection{THE StRUCTURE OF COMPLICITY IN INTERNATIONAL CRIMINAL LAW}

\subsubsection{Differentiation in the Attribution of Responsibility}

As we saw in Chapter 2, complicity is a particular mode of wrongdoing. Reflected in law, this requires that accomplices are held responsible for their own complicit contribution to the principal's wrong and not for the principal's wrong itself. The corollary of this point is a preference for non-imputational complicity rules: those who help or influence a principal perpetrator should be convicted of a crime defined in those terms - instigating war crimes, aiding crimes against humanity, or abetting

\footnotetext{
${ }^{490}$ Akayesu (Trial Chamber Judgment) [498].

${ }^{491}$ As in Krstić. See Krstić (Appeals Chamber Judgment) [133]-[134].

492 See Krstić (Appeals Chamber Judgment) [137].

${ }^{493}$ Werle, 'Individual Criminal Liability' 969-970.
} 
genocide — and punished for their own contribution to the principal's wrong. ${ }^{494}$

Liability of this kind is still derivative in that the complicit actor's conduct is linked to the principal offence. But it is not imputational. In evaluating the nature of the rules, Chapter 2 also argued that it is insufficient to look only to legal doctrine - that is, whether the system recognises different forms of complicity as a matter of doctrine. Rather, it is important to ask of what crime the defendant was convicted and for what crime was he punished? ${ }^{495}$

Under Article 6 of the Nuremberg Charter, accomplices were responsible for all acts committed by the principal; under Article 2 of Allied Control Council Law No. 10, accessories and abettors were deemed to have committed the principal's crime. $^{496}$ At the ad hoc tribunals, there is evidently doctrinal differentiation among different participants: we can specify, as a matter of legal doctrine, the elements of rules prohibiting instigation and aiding and abetting. But there is no differentiation in the attribution of responsibility. The provisions on criminal responsibility in the statutes of the tribunals specify that any person who instigated or aided and abetted a crime within the jurisdiction of the tribunal 'shall be individually responsible for the crime. ${ }^{497}$ In practice, this is how the tribunals have proceeded. Stewart points out that in $95 \%$ of cases involving convictions for aiding and abetting, instigating, ordering, or planning, the disposition makes no mention of the particular doctrine in

\footnotetext{
${ }^{494}$ See Ch. 2.4.1 above.

${ }^{495}$ See Ch. 2.4.2 above.

${ }^{496}$ Art 6 Nuremberg Charter; Art II(2) Allied Control Council Law No. 10, Punishment of Persons Guilty of War Crimes, Crimes against Peace and Humanity (20 December 1945) 3 Official Gazette Control Council for Germany 50-55 (1946).

${ }^{497}$ Art 7(1) ICTY Statute, Art 6(1) ICTR Statute.
} 
play. ${ }^{498}$ Rather, the defendant is convicted of the underlying crime he aided, abetted, or instigated. ${ }^{499}$

In this way, the approach of the ad hoc tribunals to complicity is similar to that in England and Wales. There is clearly doctrinal differentiation-we can look to the law reports and textbooks to find out exactly what it means to aid, abet, or instigate. Moreover, it is often implicitly, and sometimes explicitly, assumed by judges that there is a gradation in culpability in different modes of participation. ${ }^{500}$ But this doctrinal differentiation does not give rise to normative differentiation at the level of responsibility. In other words, the principal's wrong is imputed to the accomplice.

This is a largely unnoticed problem in international criminal law, and it is one that will likely continue under the Rome Statute. Article 25(3) of the Rome Statute sets out a number of modes of responsibility, including commission, ordering, and complicity. Moreover, it appears as though Article 25(3) is an attempt to grade the culpability of different participants, from most grave in 25(3)(a) to least grave in $25(3)(d) .{ }^{501}$ So there is evidently doctrinal differentiation, combined with an attempt to differentiate normatively at the level of responsibility.

\footnotetext{
${ }^{498}$ Stewart, 'The End of Modes of Liability' n.114.

${ }^{499}$ Ibid. Van Sliedregt, Individual Criminal Responsibility 80-81. See also Prosecutor v Taylor (Appeals Chamber Judgment) [366].

${ }^{500}$ See e.g. Tadić (Appeals Chamber Judgment) [192]:
}

Under these circumstances, to hold criminally liable as a perpetrator only the person who materially performs the criminal act would disregard the role as co-perpetrators of all those who in some way made it possible for the perpetrator physically to carry out that criminal act. At the same time, depending upon the circumstances, to hold the latter liable only as aiders and abettors might understate the degree of their criminal responsibility. (emphasis added).

${ }^{501}$ Werle, 'Individual Criminal Responsibility' 957. 
However, this intention was not realised in the drafting of the statute: Article 25(3) provides that any person who fulfills one of those modes of responsibility 'shall be criminally responsible and liable for punishment for a crime within the jurisdiction of the Court. ${ }^{, 502}$ That phrasing is worth emphasising: accomplices 'shall be criminally responsible and liable for punishment for a crime within the jurisdiction of the Court.' In other words, instigation under Article 25(3)(b), and aiding, abetting or otherwise assisting under Article 25(3)(c), are ways that an individual may be responsible for genocide, war crimes or crimes against humanity. Whether we call these modes of participation, modes of liability or modes of attribution, ${ }^{503}$ the outcome is the same: participants are responsible for the underlying crime. ${ }^{504}$

This conclusion follows from the language used as well as from the structure of criminal responsibility embraced by the Rome Statute. ${ }^{505}$ In this model, committing a crime is just another way that one might become criminally responsible for it. ${ }^{506}$ This appears to deny that there is anything special about commission. However, when committers are held responsible for the principal crime, it was their acts of killing, inflicting, or forcibly transferring that constituted the crime. ${ }^{507}$ There are no culpability or fair labelling concerns.

\footnotetext{
${ }^{502}$ Art 25(3) Rome Statute.

${ }^{503}$ Stewart, 'The End of Modes of Liability' n.2.

${ }^{504}$ Ambos seems to implicitly agree that this is the effect of Article 25. See Ambos, 'Individual Criminal Responsibility' 745: 'This approach confirms the general tendency in comparative criminal law to reject a pure unitarian concept of perpetration (Einheitstätermodell) and to distinguish, at least on the sentencing level, between different forms of participation.' (emphasis added).

${ }^{505}$ See Van Sliedregt, Individual Criminal Responsibility 85.

${ }^{506}$ Art 25(3) Rome Statute. I am grateful to Thomas Liefländer and Kubo Mačák for discussion on this point.

${ }^{507}$ See Art 6 Rome Statute.
} 
Why, however, should instigators or aiders be 'criminally responsible and liable for punishment for' the crime committed by the perpetrator? Solicitors, inducers, and aiders and abettors ought not be convicted of crimes that they did not commit. Instead, they ought to be convicted of soliciting genocide or aiding war crimes, as they case may be. The model of criminal responsibility employed by the Rome Statute is commendable in its attempt to distinguish the different ways we might participate in crime. It is not commendable in rendering those different participants responsible for the underlying crime.

The structural scheme in the Rome Statute is not dissimilar to the German Criminal Code: three forms of perpetration, a prohibition on instigation, and a provision on aiding and abetting. ${ }^{508}$ What is different is the prefatory language in the Rome Statute that explicitly makes all parties responsible for the crime committed by the principal. It is not inconceivable that in interpreting the Rome Statute, the court could give effect to the drafters' aims of establishing a gradation of culpability amongst participants that differentiates at the level of the attribution of responsibility. ${ }^{509}$ In so doing, the currently accepted doctrinal differentiation would be reflected at the conviction stage.

\subsubsection{Differentiation at Sentencing}

Leaving aside those interpretive hopes for the Rome Statute, given that there is no normative differentiation at the level of responsibility, what about differentiation in sentencing? At the ad hoc tribunals, Trial Chambers are required to 'take into

\footnotetext{
${ }^{508} \mathrm{StGB} \S 25,26,27$.

${ }^{509}$ See Art 31 VCLT.
} 
account such factors as the gravity of the offence and the individual circumstances of the convicted person. ${ }^{, 510}$ In the case law, the gravity of the offence has been taken to include the form and degree of the accused's participation in the crime. ${ }^{511}$ In Vasiljevic', the Appeals Chamber stated that 'aiding and abetting is a form of responsibility which generally warrants a lower sentence than is appropriate to responsibility as a co-perpetrator. ${ }^{, 512}$ In terms of outcomes, aiders and abettors are generally given a lower sentence than orderers, perpetrators, or participants in a JCE. ${ }^{513}$ At the ICTY, the median sentence for aiding and abetting for all cases up to June 2010 was fifteen years, compared to eighteen for perpetrators. ${ }^{514}$ Interestingly, the median sentence of instigators was twenty-five years, though the sample size was only three cases. ${ }^{515}$

The cases establish a discretionary mitigation principle for aiders and abettors at the ICTY. ${ }^{516}$ There are insufficient data to draw any firm conclusions about the doctrine of instigation but a tendency towards the German model where instigators do not receive a discount vis-à-vis the principal may be assumed. ${ }^{517}$ It is too soon to draw any firm conclusions about the ICC. Article 78(1) of the Rome Statute borrows language from the statutes of the tribunals in providing that in determining sentence,

\footnotetext{
${ }^{510}$ Art 24(2) ICTY Statute, Art 23(2) ICTR Statute. See also Rule 101 ICTR/ICTY Rules of Procedure and Evidence (22 May 2013) IT/32/Rev. 49.

${ }^{511}$ See e.g. Čelebići (Appeals Chamber Judgment) [731]; Kupreškić et al (Trial Chamber Judgment) IT-95-16-T (14 January 2000) [852]. See also Barbora Holá, Alette Smeulers and Catrien Bijleveld, 'International Sentencing Facts and Figures - Sentencing Practice at the ICTY and ICTR' (2011) 9 J. Intl Crim. Just. 411, 415.

${ }^{512}$ Vasiljević (Appeals Chamber Judgment) IT-98-32-A (25 February 2004) [182]. See also Krstić (Appeals Chamber Judgment) [240]; Werle, 'Individual Criminal Responsibility' 955.

${ }^{513}$ Holá, Smeulers and Bijleveld, 'International Sentencing' 417.

${ }^{514}$ Ibid 429.

${ }^{515}$ Ibid.

${ }^{516}$ Van Sliedregt, Individual Criminal Responsibility 79.

${ }^{517}$ See StGB $\S 26$.
} 
the court should 'take into account such factors as the gravity of the crime and the individual circumstances of the convicted person. ${ }^{518}$ In this respect, it is likely that the court's determination will include an assessment of the offender's role. ${ }^{519}$

In sum, then, the paradigm forms of complicity in international criminal law are doctrines through which the complicit party may be held responsible for a crime committed by another party. This violates the principles of culpability and fair labelling. The violation is somewhat mitigated by the discretion available to judges at the sentencing stage. In this respect, judges are able to take into account the particularities of the complicit party's role in the commission of the crime. However, mitigation of sentence does not overcome the principled demand that instigators should be held responsible for instigating, aiders responsible for aiding, and abettors responsible for abetting.

\subsection{LOCATING THE RULES WITHIN THE ANALYTICAL FRAMEWORK}

The doctrines of instigation and aiding and abetting form a significant part of the wider story of international law's regulation of complicity. As part of that wider story, this thesis places these rules of complicity into a single analytical framework. The first axis of analysis concerns the forms of complicity prohibited. Here, international criminal law's approach is broad. This point is illustrated by reference to the establishment of the rules. In some legal regimes, rules of complicity develop organically from an initial absence to a prohibition of a certain kind of complicit conduct. As will be seen, as a matter of the primary obligations of states,

\footnotetext{
${ }^{518}$ Art 78(1) Rome Statute.

${ }^{519}$ Schabas, A Commentary on the Rome Statute 902. See also the discussion in Prosecutor v Taylor (Appeals Chamber Judgment) [646]-[671].
} 
international law prohibits states from allowing their territory to be used in the commission of acts of aggression by other states. This is a complicity rule, but it is not one that was derived from a general prohibition on complicity. Rather, a specific kind of complicit conduct in a specific wrong is prohibited.

Complicity in international criminal law started from the opposite position. As part of the general provisions on international criminal responsibility, a prohibition on complicity is established. This prohibition takes the form of general doctrinesinstigation and aiding and abetting. Together, these doctrines occupy the field of how we might be complicit in another's acts, denoting both the provision of help and psychological influence. An important point springs from this approach. The range of conduct that might give rise to complicity liability is immensely broad. Any action that aids, abets, or instigates another's commission of crime is potentially implicated. The breadth of the conduct element demands the development of a nexus requirement, the second axis of the framework. Without such a requirement, complicity liability is likely to inculpate actors who make very minor contributions to wrongdoing. At present, the case law sets out a test of 'substantial assistance', though there is little evidence that it is being applied diligently.

The final issue concerns the fault required of accomplices. Here, international criminal law prescribes a standard of knowledge. Best captured in the judgment of ICTY Trial Chamber in Kunarac, the accomplice must 'take the conscious decision to act in the knowledge that he thereby supports the commission of the crime. ${ }^{520}$ It should be reiterated that the Rome Statute follows this approach for instigators but

\footnotetext{
${ }^{520}$ Kunarac, Kovač, Vuković (Trial Chamber Judgment) IT-96-23-T \& IT-96-23/1-T (22 February 2001) [392]. See Boas et al, Forms of Responsibility 321.
} 
introduces a purposeful standard for those who aid, abet, or otherwise assist the principal. ${ }^{521}$ They must act with 'the purpose of facilitating the commission' of such a crime. Given that many acts of psychological influence will fall under Article 25(3)(b), and thus entail a standard of knowledge, the purpose standard will apply mostly to material acts of assistance, or, in Kadish's terminology, the provision of help to the principal. ${ }^{522}$ It is doubtful that cases of knowing aid ought to be excluded from the ambit of complicity.

Part of the value of mapping these rules onto a single analytical framework is to illustrate how the different elements of any complicity rule work together. Complicity liability tends to be overbroad when any conduct carried out with knowledge of the principal's intention and without a substantiality requirement is sufficient to render the actor an accomplice. A standard of purpose that only applies in respect of very particular kinds of substantial assistance is likely to exculpate actors who ought to be liable as an accomplice. In international criminal law, these issues must be located within a structural scheme that holds accomplices responsible for the underlying crime committed by the principal.

\subsection{COMPLiCITY In GeNOCIDE - A CODA FOR NON-IMPUTATIONAl COMPLiCity}

\subsubsection{Introduction}

In defining the crime of genocide in the statutes of the ICTY and ICTR, the Security

Council borrowed the definition set out in Article II of the Genocide Convention. ${ }^{523}$

\footnotetext{
${ }^{521}$ Arts 25(3)(b), 25(3)(c), 30 Rome Statute.

${ }^{522}$ Kadish, 'Complicity, Cause and Blame' 342.

${ }^{523}$ UNSC Res 827; UNSC Res 955.
} 
In addition, it lifted unchanged Article III. ${ }^{524}$ For this reason, the statutes of both tribunals provide a definition of genocide and specify that, in addition to genocide, the following acts are also punishable: conspiracy, incitement, attempt, and complicity. ${ }^{525}$ The reference to complicity in genocide is interesting, for it suggests that complicity might be a substantive crime in its own right. The question, then, is how this reference to complicity in genocide is reconciled with the statutes' provisions on individual criminal responsibility, which include aiding and abetting as a mode of participation in the substantive crimes within the tribunals' jurisdiction. ${ }^{526}$

\subsubsection{Case Law}

This question has provoked a great deal of academic discussion. ${ }^{527}$ As a matter of positive law, a confusing starting point is the judgment of the ICTR Trial Chamber in Akayesu. On its interpretation, complicity in genocide is a substantive crime marked by different mens rea and actus reus requirements from aiding and abetting as a mode of participation in genocide. ${ }^{528}$ Doubt was cast on this position by decisions of the ICTR in Semanza and ICTY in Stakić. ${ }^{529}$ These decisions may be read to suggest that there is 'no material distinction' between complicity in genocide and aiding and

\footnotetext{
${ }^{524}$ Genocide Convention.

${ }^{525}$ Art 4(3) ICTY Statute, Art 2(3) ICTR Statute.

${ }^{526}$ This issue does not arise under the Rome Statute: see Arts 6, 25.

${ }^{527}$ See Chile Eboe-Osuji, “"Complicity in Genocide” versus "Aiding and Abetting Genocide”: Construing the Difference in the ICTR and ICTY Statutes' (2005) 3 J. Intl Crim. Just. 56; Grant Dawson and Rachel Boynton, 'Reconciling Complicity in Genocide and Aiding and Abetting Genocide in the Jurisprudence of the United Nations Ad Hoc Tribunals' (2008) 21 Harv. Human Rights J. 241; Flavia Giustiniani, 'The Responsibility of Accomplices in the Case-Law of the Ad Hoc Tribunals' (2009) 20 Crim. L. Forum 417, 435-441; Daniel Greenfield, 'The Crime of Complicity in Genocide: How the International Criminal Tribunals for Rwanda and Yugoslavia Got It Wrong, and Why It Matters' (2008) 98 J. Crim. L. \& Criminology 921.

${ }^{528}$ Akayesu (Trial Chamber Judgment) $545-548$.

${ }^{529}$ Semanza (Trial Chamber Judgment) [394]; Stakić (Trial Chamber Judgment) IT-97-24-T (31 July 2003) [531].
} 
abetting genocide. ${ }^{530}$ In Krstić, the Appeals Chamber of the ICTY specifically noted the variant approaches. At first, it seemed to suggest that Article 7(1), the Statute's provision on individual criminal responsibility, was the proper route for litigating potentially complicit conduct. However, the Appeals Chamber proceeded to maintain that 'complicity in genocide' might be distinct from aiding and abetting liability on the basis that it 'may encompass broader conduct than that of aiding and abetting., 531

In Karemera, the accused were charged with (i) genocide committed by means of a joint criminal enterprise and, in the alternative, (ii) complicity in genocide committed by means of a joint criminal enterprise. ${ }^{532}$ In other words, on the prosecutor's construction complicity in genocide was a substantive crime that was perpetrated by the defendants through the mode of JCE. This was firmly rejected by the ICTY Trial Chamber:

Whereas the genocide is the crime, joint criminal enterprise and complicity in genocide are two modes of liability, two methods by which the crime of genocide can be committed and individuals held responsible for this crime. It is therefore impossible to plead that complicity in genocide has been committed by means of a joint criminal enterprise. Complicity can only be pleaded as a form of liability for the crime of genocide. ${ }^{533}$

It is a stretch to suggest that a single Trial Chamber decision has settled the matter. One of the three judges, Judge Short, issued a separate opinion disagreeing

\footnotetext{
${ }^{530}$ Semanza (Trial Chamber Judgment) [394].

${ }^{531}$ Krstić (Appeals Chamber Judgment) [139].

${ }^{532}$ Karemera, Ngirumpatse, Nzirorera (Trial Chamber Decision on Defence Motions Challenging the Pleading of a Joint Criminal Enterprise in a Count of Complicity in Genocide in the Amended Indictment) ICTR-98-44-T (23 May 2006) [1].

${ }^{533}$ Ibid [8].
} 
with the majority's reasoning. ${ }^{534}$ Short pointed out that the authority on which the majority purported to rely to establish that complicity in genocide is only a mode of liability is far less categorical and consistent than the majority assumes. ${ }^{535}$ His own solution attempts to split the difference: 'In my view, complicity in genocide has the indicia of a criminal offence, whilst encompassing a particular mode of liability., 536 As things stand, the position is unclear. ${ }^{537}$

\subsubsection{Academic Discussion and Analysis}

Chile Eboe-Osuji, now a judge at the ICC, provides one of the earlier academic attempts to resolve the issue. Eboe-Osuji's starting point is that the drafters used two terms that essentially mean the same thing but that a rule of effective construction-ut res magis valeat quam pereat - demands that judges make 'every interpretative effort' to reasonably give effect to the text of the Statutes without overlap or redundancy. ${ }^{538}$ On his interpretation, there are a number of constructions that may be adopted on the basis of such an interpretive effort. One of these is Akayesu's preference for different mens rea (and actus reus) standards. ${ }^{539}$ This Eboe-Osuji rejects on the basis that distinguishing complicity in genocide and aiding and abetting by reference to finegrained elemental distinctions is strained and hard to justify. ${ }^{540}$ His preferred solution focuses on the purpose of each provision within the context of the statute as a whole.

\footnotetext{
${ }^{534}$ Karemera et al (Separate Opinion of Judge Short on Trial Chamber Decision on Defence Motions Challenging the Pleading of a Joint Criminal Enterprise in a Count of Complicity in Genocide in the Amended Indictment) [7]-[8].

535 Ibid.

${ }^{536}$ Ibid [8].

${ }^{537}$ See also Blagojević, Jokić (Trial Chamber Judgment) [777]; Brđanin (Trial Chamber Judgment) [725].

${ }^{538}$ Eboe-Osuji, 'Complicity in Genocide' 59.

${ }^{539}$ Akayesu (Trial Chamber Judgment) [545]-[548].

${ }^{540}$ Eboe-Osuji, 'Complicity in Genocide' 67.
} 
The provision on individual criminal responsibility prescribes that those who aid and abet genocide are responsible for genocide itself. Complicity in genocide appears within the definitional section of substantive crimes. This substantive crime should be interpreted to capture (i) accessories after the fact and (ii) a 'residue of culpable genocide-related conducts that do not rise to the level of individual responsibility described in Article 6(1). ${ }^{, 541}$

Eboe-Osuji's approach is the most interesting attempt to resolve the apparent contradiction. Others have been put forward. Some writers seek to maintain a finegrained elemental distinction between complicity as a crime and aiding and abetting as a mode rejected by Eboe-Osuji. ${ }^{542}$ Dawson and Boynton adopt what they call a heads of responsibility approach. On this view, complicity in genocide is hybrid of a substantive crime and mode of liability. ${ }^{543}$ As a substantive crime, it may be committed through any of the modes of liability under Article 6(1), including aiding and abetting. The authors concede that this would mean that one could aid and abet complicity to commit genocide, but suggest this is a minor issue within their doctrinal scheme as a whole. ${ }^{544}$

All attempts, judicial and academic, to distinguish complicity and aiding and abetting are marked by a similar sense of strain. This is because the two concepts express the same idea: assisting or encouraging another person to perpetrate a crime is wrong. If this starting point is correct, how can the inclusion of complicity in

\footnotetext{
${ }^{541}$ Ibid 79 (emphasis omitted).

${ }^{542}$ See e.g. Greenfield, 'The Crime of Complicity in Genocide'.

${ }^{543}$ Dawson and Boynton, 'Reconciling Complicity in Genocide' 278. See also Karemera (Separate Opinion of Judge Short) [8].

${ }^{544}$ Dawson and Boynton, 'Reconciling Complicity in Genocide' 278.
} 
genocide as a substantive crime be explained? The answer is simple and, indeed, implicitly illustrated by the strained attempts at reconciliation: the comprehensive and verbatim lifting of Articles II and III of Genocide Convention resulted in the inclusion of a redundant provision in both statutes.

It is inconceivable that having decided on the general approach to criminal liability represented in Articles 6(1) and 7(1), including the provision of complicity liability through the doctrines of aiding and abetting and instigation, the drafters decided to carve out a special substantive crime of complicity in genocide. It would follow that such a crime could be committed through all other modes, including aiding and abetting and instigation. The better explanation is that a perceived desire to avoid a loophole let to the inadvertent inclusion of a redundant provision. ${ }^{545}$ This point is widely understood and is implicitly accepted by the Appeals Chamber of the Krstić:

Because the Statute must be interpreted with the utmost respect to the language used by the legislator, the Appeals Chamber may not conclude that the consequent overlap between Article 7(1) and Article $4(3)(e)$ is a result of an inadvertence on the part of the legislator where another explanation, consonant with the language used by the Statute, is possible. ${ }^{546}$

In other words, we know that it was inadvertence, but we must try to explain it away. In a similar vein, Eboe-Osuji presents his attempt to explain the contradiction with the qualification that it follows from his understanding that it must be explained.

\footnotetext{
${ }^{545}$ See Schabas, The UN International Criminal Tribunals 183; Marko Milanović, 'State Responsibility for Genocide: A Follow Up' (2007) 18 Eur. J. Intl L. 669, 680.

${ }^{546}$ Krstić (Appeals Chamber Judgment) [139].
} 
He concedes that his solution does not follow 'from a definitional or elemental conception of "complicity", 547

The attempts to explain it are either interpretively strained beyond breaking point or do not resolve the redundancy. ${ }^{548}$ Even if some solution could be reached that carves out a specific substantive crime of complicity in genocide, it would still fail to cohere with the general structure of criminal liability set out in the statutes of the tribunals and in international criminal law more generally. A better approach would be to abandon the search for a substantive crime of complicity in genocide and continue to develop a coherent conception of complicity liability through aiding and abetting. The rule of effective construction is not unlimited.

Within the context of this thesis, this argument is somewhat paradoxical. After all, the thesis' normative argument is that non-imputational rules of complicity are a more principled way to hold responsible those who influence or assist others to commit wrongdoing. On this basis, it might be thought that complicity in genocide ought to be considered a substantive crime in its own right. However, the incoherence of such a crime within the general structure of liability would cause more harm than good. Moreover, this issue does not arise under the Rome Statute, and it is not inconceivable that the ICC could interpret Article 25 in a way that realises the broader normative claim of the thesis - that the doctrinal differentiation amongst participants in crime in Article 25 is carried through into differentiation at the level of responsibility.

\footnotetext{
${ }^{547}$ Eboe-Osuji, 'Complicity in Genocide' 79.

${ }^{548}$ See Boas et al, Forms of Responsibility 301; Payam Akhavan, 'The Crime of Genocide in the ICTR Jurisprudence' (2005) 3 J. Intl Crim. Just. 989, 994.
} 


\subsection{CONCLUSION}

Complicity is primarily accounted for in international criminal law through the doctrines of instigation and aiding and abetting. The distinction drawn between serious forms of influence over the perpetrator and less serious encouragement is to be supported. In content, the rules are marked by their breadth in terms of the conduct they prohibit, a standard of knowledge in the fault element, and an explicit but underdeveloped substantiality criterion in assessing the relationship between the accomplice's actions and the principal's crime. In terms of structure, there is no differentiation between principals and accomplices in the attribution of responsibility. Accomplices are responsible for the crime committed by the principal. 


\section{CHAPTER 5. CULPABLE OMISSIONS AND COMPLICITY IN INTERNATIONAL CRIMINAL LAW}

\subsection{INTRODUCTION}

Other than the case of the approving spectator, the discussion of complicity in Chapter 4 assumed that the conduct at issue is an action - the provision of weapons, the guarding of a detainee, the shout of encouragement. Chapter 5 considers how international criminal law deals with complicit omissions. ${ }^{549}$ It does so in two ways. First, it is now recognised that an omission is another way that the conduct element of aiding and abetting liability may be fulfilled. As a matter of fact, some omissions do aid or abet a principal's commission of crime. Morally, some of those failures to act are sufficiently culpable to place the actor on an equivalent footing to those who help or influence by positive action. Second, failure by a superior to prevent crimes carried out by her subordinates gives rise to liability under the doctrine of command responsibility. At least where the superior had actual knowledge of the crimes, the rule may be regarded as a very specific iteration of complicity by omission. Where the superior ought to have known that her subordinates were committing or about to commit the crimes, the doctrine of command responsibility may be thought of as a species of negligent complicity.

\subsection{Aiding AND ABetTing By OMission}

\subsubsection{Introduction}

The case law of the ad hoc tribunals establishes that a failure to fulfill a legal duty may give rise to international criminal liability for aiding and abetting by omission. Some earlier formulations of the conduct element of aiding and abetting seem to limit

\footnotetext{
${ }^{549}$ On the distinction between acts and omissions, see generally Fletcher, Rethinking Criminal Law 421-439; Kadish, 'Act and Omission, Mens Rea, and Complicity.'
} 
its scope to acts. ${ }^{550}$ In Blaškić, the Appeals Chamber of the ICTY explicitly raised the possibility that an omission could found aiding and abetting liability but did not rule on it. ${ }^{551}$ The absence of unambiguous examples of aiding and abetting by omission was noted by the ICTR Trial Chamber in Mpambara, ${ }^{552}$ and led some commentators to conclude that there is no proper support for aiding and abetting by omission as a form of responsibility in international criminal law. ${ }^{553}$

Such a conclusion is no longer tenable after the Mrkšić case at the ICTY. Beyond its affirmation of legal principle, Mrkšić provides an example of the potential factual basis of omissions liability in international criminal law, an analysis of the essential criterion of duty, and a foundation for the development and critique of the law. The defendants, Veselin Šljivančanin, Mile Mrkšić and Miroslav Radić were charged with crimes committed in November 1991 against Croats and others who had sought refuge in Vukovar hospital after the fall of the city. ${ }^{554}$ The victims were evacuated from the hospital to Ovčara farm, where they were tortured and eventually executed. ${ }^{555}$ In the main, the crimes were physically perpetrated by Territorial Defence (TO) forces and paramilitaries rather than by soldiers of the Yugoslav People's Army (JNA). The case concerned the relationship between the defendants, all officers in the JNA, and the crimes committed at Ovčara.

\footnotetext{
${ }^{550}$ See e.g. Vasiljević (Appeals Chamber Judgment) [102]: 'The aider and abettor carries out acts specifically directed to assist, encourage or lend moral support to the perpetration of a certain specific crime ... and this support has a substantial effect upon the perpetration of the crime.'

${ }^{551}$ Blaškić (Appeals Chamber Judgment) [47].

${ }^{552}$ Mpambara (Trial Chamber Judgment) ICTR-01-65-T (11 September 2006) [23].

${ }^{553}$ See Boas et al, Forms of Responsibility 314-315.

${ }^{554}$ Mrkšić et al (Trial Chamber Judgment) [1].

${ }^{555}$ Ibid [539].
} 
Šljivančanin was a major in the Yugoslav People's Army. He was put in charge of evacuating the hospital in which the victims had sought refuge by his superior, Colonel Mrkšić. ${ }^{556}$ Under Šljivančanin's orders, the victims were transported from the hospital to Ovčara farm via the local JNA barracks. A number of TO forces and paramilitaries gathered at the farm. In the course of the day, acts of torture and cruel treatment were perpetrated against the victims, predominantly by the TO forces and paramilitaries. Military police within the official structure of the JNA were present at Ovčara, ostensibly to ensure the security of the prisoners. On Mrkšić's orders, they withdrew in the early evening. ${ }^{557}$ The withdrawal left the prisoners under the control of the TO forces and paramilitaries. Shortly after the withdrawal, the TO forces and paramilitaries murdered the prisoners. ${ }^{558}$

\subsubsection{The ICTY Trial Chamber in Mrkšić}

It is helpful to split the substantive crimes into (a) murder as a violation of the laws and customs of war and (b) torture and cruel treatment as violations of the laws and customs of war. The charges of crimes against humanity were dismissed on the basis of the absence of the required jurisdictional requirements under Article 5 of the Statute. ${ }^{559}$ The indictment charged the defendants with a number of modes of responsibility under Article 7(1) of the Statute. On the charge of joint criminal enterprise, the Trial Chamber found that the evidence did not support individual

\footnotetext{
${ }^{556}$ Ibid [400].

${ }^{557}$ Ibid [293].

${ }^{558}$ Ibid [613].

${ }^{559}$ Ibid [711].
} 
responsibility. Likewise, the defendants were not found to have planned, ordered, or instigated the crimes. ${ }^{560}$ Only aiding and abetting liability remained.

Mrkšić was convicted of aiding and abetting murder on the basis that his order for the JNA soldiers to withdraw from the farm rendered substantial practical assistance to the TO forces and paramilitaries who executed the prisoners. The Trial Chamber was satisfied that when he gave the order he was aware the TO forces and paramilitaries presented a grave threat to the prisoners of war. ${ }^{561}$ On the charges of torture and cruel treatment, the evidence demonstrated that Mrkšić knew that violence was being committed against the prisoners and that the TO forces and paramilitaries had a propensity towards extreme violence. ${ }^{562}$ He had readily available means to ensure that the violence abated, and yet failed to act. This failure was found to have rendered practical assistance to the perpetrators of cruel treatment and torture. ${ }^{563}$

Šljivančanin was convicted by the Trial Chamber of aiding and abetting torture by omission. His initial involvement in the transfer of prisoners to Ovčara was not the basis of this conviction - participation therein was not allied with anticipation of the crimes subsequently committed. ${ }^{564}$ Rather, it was that he was aware of the mistreatment of prisoners, was under a duty to prevent further commission of such harms, and made no effort to do so. ${ }^{565}$ The Trial Chamber found

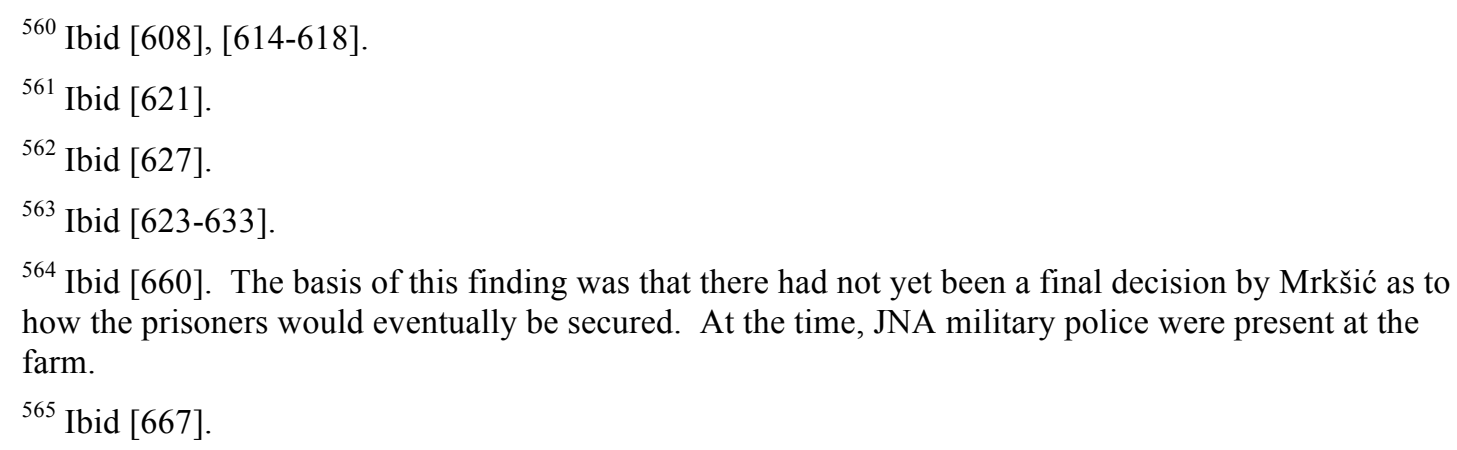
how the prisoners would eventually be secured. At the time, JNA military police were present at the farm.

${ }^{565}$ Ibid [667]. 
three sources for such a duty: (i) the laws and customs of war, in particular Article 13 of the Third Geneva Convention; (ii) Šljivančanin's remit as chief security officer of the relevant division of the JNA; and (iii) the specific responsibility for the security of the prisoners entrusted to him by Mrkšić, his superior. ${ }^{566}$ The Trial Chamber set out a number of measures he could have taken to fulfill this duty. ${ }^{567}$ In failing to do so, it was found that he must have been aware that he was facilitating the commission of torture and cruel treatment.

The Trial Chamber did not convict Šljivančanin of aiding and abetting murder by omission. In this regard, the events should be divided into pre- and postwithdrawal of the JNA forces. At the time of Šljivančanin's visit to the farm in the afternoon — before the withdrawal — it was found that he could reasonably have believed that the TO forces and paramilitaries would not have killed the prisoners. ${ }^{568}$ This was because of the ongoing presence of the JNA forces. As noted above, after Mrkšić gave the order to withdraw, the prisoners were murdered. In the Trial Chamber's view, Šljivančanin's responsibility for providing for the security of the prisoners ended with the withdrawal of the last JNA troops. On this basis, although he may have had the requisite mens rea, he was not longer under a duty to act. ${ }^{569}$

\subsubsection{The ICTY Appeals Chamber in Mrkšić}

The prosecution appealed Šljivančanin's acquittal for aiding and abetting murder by omission. As to the events before the withdrawal of the JNA soldiers, the Appeals

\footnotetext{
${ }^{566}$ Ibid [668].

${ }^{567}$ Ibid [670].

${ }^{568}$ Ibid [672].

${ }^{569}$ Ibid [673].
} 
Chamber upheld the Trial Chamber's findings: 'it was [not] unreasonable for the Trial Chamber to find that it was unable to conclude that, at the time of his visit to Ovčara, Šljivančanin was aware that the prisoners of war would probably be murdered...,570 As to the events after the withdrawal, the Appeals Chamber first held that Šljivančanin must have known of Mrkšić's order to withdraw and therefore that it was likely that the prisoners would be killed. ${ }^{571}$ This finding left the vexing issue whether Šljivančanin owed a duty to secure the welfare of the prisoners after the order to withdraw had been given.

In this regard, the prosecution argued that Šljivančanin was under a continuing legal duty under international humanitarian law. ${ }^{572}$ In focusing on the putative duty imposed by international humanitarian law, the prosecution appeared to concede (i) that no duty arose on the basis of Šljivančanin's position as chief security official, and (ii) that his specially delegated authority from Mrkšić had been terminated on Mrkšić's order to withdraw. ${ }^{573}$ The Appeals Chamber first ruled on the applicability of the Third Geneva Convention and Common Article 3 to the conflict. ${ }^{574}$ Article 13 of GCIII provides that '[a]ny unlawful act or omission by the Detaining Power causing death or seriously endangering the health of a prisoner of war in its custody is prohibited, and will be regarded as a serious breach of the present Convention. ${ }^{575}$ Although this provision is directed to the Detaining Power, the Appeals Chamber

\footnotetext{
${ }^{570}$ Mrkšić, Šljivančanin (Appeals Chamber Judgment) [60].

${ }^{571}$ Ibid [62].

${ }^{572}$ Ibid [64].

${ }^{573}$ Ibid [64].

${ }^{574}$ Ibid [70].

${ }^{575}$ Art 13 Convention (III) Relative to the Treatment of Prisoners of War (adopted 12 August 1949, entered into force 21 October 1950) 75 UNTS 135 (GCIII).
} 
found that members of armed forces also acquire these international obligations with respect to prisoners of war. ${ }^{576}$ These moves culminated in its finding that:

Geneva Convention III invests all agents of a Detaining Power into whose custody prisoners of war have come with the obligation to protect them by reason of their position as agents of that Detaining Power. No more specific investment of responsibility in an agent with regard to prisoners of war is necessary. The Appeals Chamber considers that all state agents who find themselves with custody of prisoners of war owe them a duty of protection regardless of whether the investment of responsibility was made through explicit delegation such as through legislative enactment or a superior order, or as a result of the state agent finding himself with de facto custody over prisoners of war such as where a prisoner of war surrenders to that agent. ${ }^{577}$

Šljivančanin's was thus under an obligation to protect the prisoners of war held at Ovčara farm and not to transfer custody of the prisoners without assuring himself that they would not be harmed by the recipients. He remained an officer of the JNA and agent of the detaining power even after the order to withdraw was given. ${ }^{578}$ On the basis that he had the requisite mens rea and that his failure to protect the prisoners substantially contributed to principal crimes, Šljivančanin was convicted of aiding and abetting murder by omission. ${ }^{579}$

\subsubsection{Analysis}

Mrkšić demonstrates how cases of complicit omission arise in times of war. The general principle that an omission may fulfill the conduct element of aiding and abetting liability should be supported. As a matter of fact, sometimes a failure to act

\footnotetext{
${ }^{576}$ Mrkšić, Šljivančanin (Appeals Chamber Judgment) [72].

${ }^{577}$ Ibid [73].

${ }^{578} \operatorname{Ibid}[75]$.

${ }^{579}$ Ibid [103]. Šljivančanin's conviction for aiding and abetting murder by omission was subsequently vacated by the Appeals Chamber in a review judgment of 8 December 2010. As noted above, Šljivančanin's conviction was based on the inference that Mrkšić must have informed him of his order to withdraw JNA soldiers securing the prisoners from Ovčara. New testimony by Miodrag Panić, a former JNA officer, made this inference untenable. See Šljivančanin (Appeals Chamber Review Judgment) IT-95-13/1-R.1 (8 December 2010).
} 
does assist the commission of crime. As a moral matter, sometimes such failures are sufficiently reprehensible as to warrant the imposition of complicity liability. The key, of course, is the existence of a duty of protection owed towards the victims. ${ }^{580}$

The case gets to the core of the issue concerning the kinds of duty that may found international criminal liability for complicity by omission. As noted, the prosecution initially pointed to three potential sources of Šljivančanin's duty to act: his duty under the laws and customs of war; his duty in his capacity as chief of the security organ; and his duty under Mrkšić's delegated authority. ${ }^{581}$ The Trial Chamber appears to recognise all three. ${ }^{582}$ During the appeal, the prosecution subsequently appeared to concede that Šljivančanin's capacity as chief of the security organ founded no duty towards the prisoners and that any delegated duty from Colonel Mrkšić had terminated. This led the Appeals Chamber to focus on the laws and customs of war as the source of the legal duty to act. In the case at hand, Article 13 of GCIII was interpreted to impose a duty on 'each agent in charge of the protection or custody of the prisoners of war to ensure that their transfer to another agent will not diminish the protection the prisoners are entitled to., 583

One possible implication of the Appeals Chamber's reasoning is that omissions liability must be founded on a duty arising under the laws and customs of war. This approach is reasonably common at the ad hoc tribunals. ${ }^{584}$ However,

\footnotetext{
${ }^{580}$ Mrkšić, Šljivančanin (Appeals Chamber Judgment) [49].

${ }^{581}$ Ibid [64].

${ }^{582}$ Mrkšić et al (Trial Chamber Judgment) [669].

${ }^{583}$ Mrkšić, Šljivančanin (Appeals Chamber Judgment) [71].

${ }^{584}$ Lars Berster, “Duty to Act” and “Commission by Omission” in International Criminal Law' (2010) 10 Intl Crim. L. Rev 619, 621-622.
} 
references to other sources of the duty may be found. In Orić, the Trial Chamber suggested that a duty to act may be located in the defendant's position of authority or in his antecedent conduct by which the victim was exposed to danger. ${ }^{585}$ In Rutaganira, the Trial Chamber of the ICTR referred not only to domestic criminal law but also to the state's obligations under international human rights law as potential sources. ${ }^{586}$ In Bagambiki, the defendant was bound by a legal duty under Rwandan domestic law — the Law on the Organization and Function of the Prefecture - to ensure the protection of those within his prefecture. ${ }^{57}$ This duty was not criminal in nature. For this reason, the Trial Chamber found that the breach could not give rise to international criminal liability. ${ }^{588}$ It recognised, however, that a domestic criminal law duty could give rise to liability. ${ }^{589}$

The question of which duties count for the purposes of omissions liability in international criminal law is a difficult one. To take a step back, in ordinary domestic criminal law cases of omission, the role of the duty is two-fold. First, it reflects a normative judgment of the legal system that a particular failure to act is so culpable that the eventuating harm should be attributed to the individual: the father ought not to watch his child drown, Miller ought not to watch his cigarette burn, and Pittwood ought not to leave his railway post unattended. ${ }^{590}$ Second, the duty fulfills doctrinal requirements of legal causation —identifying a specific person whose culpable

\footnotetext{
${ }^{585}$ Orić (Trial Chamber Judgment) [304].

${ }^{586}$ Rutaganira (Trial Chamber Judgment) ICTR-95-1C-T (14 March 2005) [78], [82]. See Berster, 'Duty to Act' 621-624.

${ }^{587}$ Ntagerura, Bagambiki, Imanishimwe (Trial Chamber Judgment) ICTR-99-46-T ((25 February 2004) [660].

588 Ibid.

${ }^{589}$ Ibid [659].

${ }^{590}$ See Ch. 2.5.2.2 above.
} 
relationship with an eventuating harm is such that she may be held responsible for it. One lesson here is that neither of the two roles of duty in criminal omissions cases has anything to do with criminal law per se. The source of the duty in each case variesit may be statutory, contractual, or based on an undertaking, it may arise on the basis of a particular relationship with the victim or it may stem from the defendant's prior creation of risk of the subsequent harm. A second lesson is that the duty is constituted as a criminal law duty by the court's determination that it is to be so.

In this instance, what is true in national legal orders should also be true on the international plane. ${ }^{591}$ Take the duty arising under the laws and customs of war in Mrkšić. As the Appeals Chamber concedes, the duties set out in the third Geneva Convention bind the high contracting parties thereto. ${ }^{592}$ The duty itself did not bind Šljivančanin. To put it another way, Šljivančanin is not being held responsible for breaching Article 13 of GCIII. Instead, we should recognise that the duty that bound Šljivančanin was constituted and imposed by the court itself. Of course, Article 13 of GCIII is central to its reasoning process. Article 13 prohibits any act or omission by a Detaining Power that causes the death of, or seriously endangers the health of, any prisoner of war within its custody. ${ }^{53}$ From this, the court reasoned that any agent of the Detaining Power into whose custody the prisoners have come is required to protect them by virtue of their position as agent. ${ }^{594}$ Failing to protect a prisoner in your custody is one of the ways that the conduct element of aiding and abetting may be fulfilled.

\footnotetext{
${ }^{591}$ See Michael Duttwiler, 'Liability for Omission' 56.

${ }^{592}$ Mrkšić, Šljivančanin (Appeals Chamber Judgment) [72].

${ }^{593}$ Art 13 GCIII.

${ }^{594}$ Mrkšić, Šljivančanin (Appeals Chamber Judgment) [73].
} 
On the basis of the same reasoning, to suggest that only the laws and customs of war could ground an international court's constitution and imposition of liability for aiding and abetting by omission would exclude from the ambit of international criminal law a range of complicit omissions for which responsibility should arise. An example might illustrate this point. A civil war is ongoing. Operatives from one of the parties to the conflict regularly ambush and murder civilians as they traipse across an exposed mountain pass. This happens every second or third night for a month. In response, the government employs two civilians to man a checkpoint on each side of the mountain pass. The two undertake to prevent any civilians from entering the pass whenever sources have informed them that the operatives are in the area. The system works and civilian deaths plummet, allowing them to cross undisturbed on the nights when the group are not operating and preventing them from crossing on nights when they are. After receiving the relevant information one night, one of the men deliberately omits to warn civilians at the checkpoint that the group is waiting on the pass. The civilians pass through the checkpoint and are murdered in violation of the laws and customs of war.

It would be difficult to argue that the checkpoint operator breached any duty to act imposed by international law. ${ }^{595}$ But to give that answer is really to ask the wrong question. Rather than asking whether the omission violated a duty imposed by international law, we should be searching for those individuals with a culpable relationship to the perpetration of the wrong proscribed by international criminal

\footnotetext{
${ }^{595}$ For a different example see Duttwiler, 'Liability for Omission' 55-56.
} 
law. ${ }^{596}$ That is the essence of complicity liability. In this case, there is little doubt that the checkpoint operator's omission aided the commission of the war crime; indeed, it is difficult to distinguish from positive conduct that might have facilitated the principal wrong. Likewise, he acted with a guilty mind. The duty arising on the basis of his undertaking to prevent such harms from occurring brings him into the category of culpable participant and ought to ground individual criminal responsibility.

This reasoning ought to be adopted at the ICC. Omissions liability in general was a matter under negotiation in the drafting process of the Rome Statute. ${ }^{597}$ Despite the inclusion of a general provision on omissions in the Draft Statute, ${ }^{598}$ it was cut from the final text, primarily owing to strong objections from France. ${ }^{599}$ The upshot of this exclusion has divided academic commentators. On one hand, Eser is emphatic that 'the abstinence from explicit regulation cannot be interpreted in any other way than the rejection of individual criminal responsibility for commission by omission... ${ }^{600}$ Ambos agrees, though is a little more tentative. ${ }^{601}$ On the other hand, Werle argues that the Statute should be interpreted to cover omissions, primarily on

\footnotetext{
${ }^{596}$ Cf Berster, 'Duty to Act' 631 .

${ }^{597}$ Duttwiler, 'Liability for Omission' 57-58.

${ }^{598}$ See Art 28(1), Report of the Preparatory Committee for the Establishment of an International Criminal Court - Draft Statute for the International Criminal Court (14 April 1998) UN Doc A/Conf.183/2/Add.1.

${ }^{599}$ Per Saland, 'International Criminal Law Principles' in Roy Lee (ed.), The International Criminal Court: The Making of the Rome Statute - Issues, Negotiations, Results (Kluwer Law International 1999) 189, 212.

${ }^{600}$ Eser, 'Individual Criminal Responsibility’ 819.

${ }^{601}$ Ambos, 'Article 25' 770.
} 
the basis that omissions liability may be seen as a general principle of law. ${ }^{602}$ This too is Duttwiler's position. ${ }^{603}$

Early indications from the Court suggest an implicit assumption that the Statute includes omissions liability. ${ }^{604}$ On assessment, the deletion of a general provision on omissions from the final text should not be seen to bar the Court from developing a theory of omissions liability. First, the Rome Statute refers to conduct rather than acts - the former being a term often seen to encompass acts and omissions. ${ }^{605}$ Omissions liability would thus not be inconsistent with the terms of the Statute. Secondly, the case law on omissions liability at the ad hoc tribunals, including liability for aiding and abetting by omission, may be a source of applicable law under Article 21(1)(b) of the Statute. ${ }^{606}$ Thirdly, Article 21(1)(c) of the Statute empowers the Court to apply general principles of law derived from national legal systems. ${ }^{607}$ In a comprehensive survey, Duttwiler demonstrates widespread recognition that omissions in the face of a duty to prevent harm are at times sufficiently culpable so as to be treated in the same way as actions. ${ }^{608}$ This widespread recognition reflects a principled assessment of the criminal wrongfulness of some omissions.

\footnotetext{
${ }^{602}$ Werle, 'Individual Criminal Responsibility' 966.

${ }^{603}$ Duttwiler, 'Liability for Omission' 60.

${ }^{604}$ See Lubanga (Decision on the Confirmation of Charges) [351]-[354].

${ }^{605}$ See Duttwiler 'Liability for Omission' 59.

${ }^{606}$ Art 21(1)(b) Rome Statute.

${ }^{607}$ Art 21(1)(c) Rome Statute.

${ }^{608}$ Duttwiler, 'Liability for Omission' 26-56.
} 
Legal systems must make judgments on which failures to act are culpable and which conduct constitutes complicity. In international criminal law, these are questions that cannot be answered unequivocally by reference to the statutes of the tribunals or the Rome Statute. In Berster's view, the use of non-criminal duties in this endeavour exceeds the judicial competence of a court not empowered to make law. ${ }^{609}$ A better view is that determining the ambit of aiding and abetting liability is not necessarily illegitimate judicial law-making. Once we recognise that certain omissions help or encourage other actors to commit a wrong, the subsequent step is to ask which of these omissions are sufficiently culpable as to justify the imposition of accomplice liability. The relevant duties may be criminal or non-criminal, international or domestic.

On this basis, some tentative sources of duty may be put forward. ${ }^{610}$ These are not necessarily exhaustive. First, certain professional or statutory obligations ought to be recognised. Duttwiler gives the example of a doctor who, after the outbreak of a genocidal programme, deliberately refuses to treat members of the persecuted minority, thereby letting them die. ${ }^{611}$ Secondly, an individual's prior dangerous act should give rise to a duty to avert the specific kind of harm threatened by that act. ${ }^{612}$ Say, for instance, a soldier is transporting landmines and absentmindedly fails to tie down the box containing the mines. The mines fall off the truck. On her way to retrieve the mines, the soldier sees a group of civilians approaching and intentionally omits to warn them. A civilian is blown up. Here, the soldier should be liable for

\footnotetext{
${ }^{609}$ Berster, 'Duty to Act' 631.

${ }^{610}$ See Kadish, 'Act and Omission, Mens Rea, and Complicity' 71 on the virtues of a 'case-by-case evolution of common law duties.'

${ }^{611}$ Duttwiler, 'Liability for Omission' 55-56.

${ }^{612}$ See Miller [1983] 2 AC 161.
} 
wilful killing as a war crime on the basis of her failure to fulfill her duty to prevent the harm from occurring. The basis of that duty is her prior dangerous act.

Thirdly, and perhaps most importantly, a duty to prevent harm may arise on the basis of a voluntary undertaking. The source of duties of this kind is sometimes described as contractual, but, taking Fletcher's position, the idea of an undertaking provides a more coherent basis for understanding why liability should be imposed. ${ }^{613}$ The undertaking to prevent harm explains the liability imposed on the lifeguard who fails to save a drowning swimmer, the railway operator who fails to close the boom, and the lookout who fails to warn civilians about the gang operating along the mountain pass. The duty not only marks out what action ought to have been taken but also plays an essentially causal role, linking the omission to the harm that resulted.

\subsubsection{Omissions and the Other Elements of Aiding and Abetting Liability}

The ad hoc tribunals have repeatedly held that the basic elements of aiding and abetting apply notwithstanding whether this form of liability is charged as an omission or an act, rejecting the argument that a more stringent nexus should arise between the omission and the principal crime. ${ }^{614}$ Both acts and omissions must have a substantial effect on the commission of the crime. ${ }^{615}$ For omissions, substantial assistance is measured in a world of counterfactuals: what would have happened if the defendant had not breached his duty to act? In this world of counterfactuals, the idea

\footnotetext{
${ }^{613}$ Fletcher, Rethinking Criminal Law 615.

${ }^{614}$ Mrkšić, Šljivančanin (Appeals Chamber Judgment) [81], [146]. See also Perišić (Trial Chamber Judgment) IT-04-81-T (6 September 2011) [134].

${ }^{615}$ Mrkšić, Šljivančanin (Appeals Chamber Judgment) [200].
} 
of substantial assistance is not always a helpful lens through which to assess responsibility.

Besides the requisite mens rea, any assessment of complicit omissions is asking: (i) should the defendant have acted to prevent the harm, and (ii) could the defendant have acted to prevent the harm? The former question shifts much of the evaluative burden onto the search for a duty to act. The latter question is one of capacity, a condition required by the principle of fairness. ${ }^{616}$ In this regard, Šljivančanin argued in Mrkšić that a number of other officers had the material ability - and were better placed — to act to prevent the mistreatment of prisoners. ${ }^{617}$ For the Appeals Chamber this did not matter, holding that the fact that the accused's omission had a more limited effect on the commission of the crime than the conduct of others did not mean that the omission could not have rendered substantial assistance. ${ }^{618}$ What the Appeals Chamber is really saying is that Šljivančanin should have acted and could have acted — that others might have acted detracts from neither of these claims.

This argument is tenable where we have narrowly circumscribed duties arising to protect against narrowly specified kinds of harm. The lifeguard at a swimming pool is the classic example. But where the scope of the duty is broad and it binds a wide-ranging class of subjects we might want the nexus element to play an increased role. Imagine their contract of employment imposes on all soldiers in the army a duty to prevent acts of torture from occurring during conflict. Twenty thousand soldiers

\footnotetext{
${ }^{616}$ Ashworth, 'Criminal Liability for Omission' 449.

${ }^{617}$ Mrkšić, Šljivančanin (Appeals Chamber Judgment) [197].

${ }^{618}$ Ibid. See also Blagojević, Jokić (Appeals Chamber Judgment) [134].
} 
are stationed on an army base and it is known a small unit is torturing prisoners. None of the soldiers acts. Are all twenty thousand liable to conviction for aiding and abetting torture by omission?

One response might emphasise that capacity to act to prevent the harm from occurring is an essential element of omissions liability. This is true as far as it goes. But even if proper emphasis is placed on capacity, it still seems that some sort of proximity requirement should be imposed for criminal liability. Of course, each of the soldiers who knew about the torture ought to have taken some steps to avert the harm, even if that was just reporting it up the chain of command. A failure in this regard could rightly give rise to direct responsibility for such a failure. But the jump to criminal accomplice liability is bigger, and in cases of broad-ranging duties we should be concerned with identifying those most responsible within the class. In this regard, proximity will look to those both close in geography and higher up within the hierarchy — the nearby commander rather than the peripheral private.

In addition to the pressure that the inclusion of omissions puts on the nexus requirement, it also puts increased focus on the required mental state of the accomplice. Consider the paradigm case of aiding and abetting by omission where the cleaner intentionally omits to lock the entrance to a bank in order to assist in a bank robbery. ${ }^{619}$ Imagine the omission was careless instead and the bank was robbed. If the legal system is using non-imputational complicity rules then a differentiated wrong of reckless complicity might be recognised. In an imputational system,

${ }^{619}$ See Ashworth, Principles of Criminal Law 410-411. 
however, recklessness or carelessness should not be the basis of attributing an intentional crime to the accomplice.

This point has implications for the assessment of the doctrine of command responsibility, a matter taken up in the section that follows. It is also relevant to the obligation on states to ensure that their territory is not used to launch hostile attacks against other states. As will be seen, international law imposes wide-ranging preventive duties on states, ordinarily conditioned by a requirement of due diligence. In most cases, failure to exercise due diligence to prevent an attack will only be a direct breach of the diligence obligation, rather than complicity in the attack itself. However, an intentional omission in the knowledge of a specific attack is a form of complicity and should give rise to responsibility in those terms. ${ }^{620}$

\subsubsection{Conclusion}

There is little difficulty in finding that some omissions assist or encourage the perpetration of crimes by other actors. Where there is a duty to act such an omission is wrongful, and the accomplice's capacity to prevent the harm establishes his role as a factual cause. The recognition of aiding and abetting by omission is significant within the analytical framework of the thesis as a whole. It represents the conviction that a failure to act may as much help or influence another's wrongdoing as positive conduct. This conclusion was made possible by the way that complicity rules in international criminal law developed. In contrast to the organic growth of complicity rules binding states, complicity in international criminal law arose from the initial

${ }^{620}$ See Ch. 2.5.2.2 above; Ch. 7.3.5.1 below. 
prescription of broad general doctrines, the interpretation of which could be extended to include complicit omissions.

\subsection{COMMAND RESPONSIBILITY}

\subsubsection{Introduction}

The previous section addressed one way that international criminal law responds to complicit omissions. This section addresses the doctrine of command responsibility in international law and its relationship with complicity. Commanders and other superiors may be criminally responsible under any of the ordinary modes of participation in international criminal law_ordering, instigating, aiding and abetting, and so on. ${ }^{621}$ International criminal law also sets out a special doctrine that responds to the culpable omissions of superiors. This is command responsibility. The prosecution of General Tomoyuki Yamashita by the US Military Tribunal in Manila is generally seen as the foundation of the doctrine. ${ }^{622}$ Giving the judgment of the Tribunal, the President found that:

[W]here murder and rape and vicious, revengeful actions are widespread offences, and there is no effective attempt by a commander to discover and control the criminal acts, such a commander may be held responsible, even criminally liable, for the lawless acts of his troops, depending upon their nature and the circumstances surrounding them. ${ }^{623}$

Despite concerns as to its source and doubts about its fairness, ${ }^{624}$ it is now recognised as a rule of customary international law. ${ }^{625}$ It is sufficient for present

\footnotetext{
${ }^{621}$ Damaška, 'The Shadow Side of Command Responsibility’ 455.

${ }^{622}$ Guénaël Mettraux, The Law of Command Responsibility (OUP 2009) 5.

${ }^{623}$ Trial of General Tomoyuki Yamashita (4 February 1946) (1948) IV LRTWC 1, 35.

${ }^{624}$ See generally In re Yamashita 327 US 1 (1946) (Dissenting Opinion of Justice Murphy); Mettraux, The Law of Command Responsibility 5-11; Damaška, 'The Shadow Side of Command Responsibility'; Jenny Martinez, 'Understanding Mens Rea in Command Responsibility’ (2007) 5 J. Intl Crim. Just
} 
purposes to sketch the elements of the doctrine. ${ }^{626}$ At the ad hoc tribunals, command responsibility comprises three elements:

1. The existence of a superior-subordinate relationship;

2. The superior knew or had reason to know that the criminal act was about to be or had been committed; and

3. The superior failed to take the necessary and reasonable measures to prevent the criminal act or punish the perpetrator thereof. ${ }^{627}$

Article 28 of the Rome Statute sets out a more detailed standard than the statutes of the ad hoc tribunals, including the elements of the rule and making separate provision for non-military superiors:

In addition to other grounds of criminal responsibility under this Statute for crimes within the jurisdiction of the Court:

(a) A military commander or person effectively acting as a military commander shall be criminally responsible for crimes within the jurisdiction of the Court committed by forces under his or her effective command and control, or effective authority and control as the case may be, as a result of his or her failure to exercise control properly over such forces, where:

(i) That military commander or person either knew or, owing to the circumstances at the time, should have known that the forces were committing or about to commit such crimes; and

(ii) That military commander or person failed to take all necessary and reasonable measures within his or her power to prevent or repress their commission or to submit the matter to the competent authorities for investigation and prosecution.

(b) With respect to superior and subordinate relationships not described in paragraph (a), a superior shall be criminally responsible for crimes within the jurisdiction of the Court

638; Darryl Robinson, 'How Command Responsibility Got So Complicated: A Culpability Contradiction, Its Obfuscation, and a Simple Solution’ (2012) 13 Melb. J. Intl L. 1.

${ }^{625}$ Čelebići (Appeals Chamber Judgment) [195].

${ }^{626}$ For doctrinal analysis, see Mettraux, The Law of Command Responsibility; Chantal Meloni, Command Responsibility in International Criminal Law (TMC Asser 2010); Schabas, A Commentary on the Rome Statute 454-465; Roberta Arnold and Otto Triffterer, 'Article 28 - Responsibility of Commanders and Other Superiors' in Triffterer (ed.), Commentary on the Rome Statute 795-843.

${ }^{627}$ Čelebići (Trial Chamber Judgment) IT-96-21-T (16 November 1998) [346]. 
committed by subordinates under his or her effective authority and control, as a result of his or her failure to exercise control properly over such subordinates, where:

(i) The superior either knew, or consciously disregarded information which clearly indicated, that the subordinates were committing or about to commit such crimes;

(ii) The crimes concerned activities that were within the effective responsibility and control of the superior; and

(iii) The superior failed to take all necessary and reasonable measures within his or her power to prevent or repress their commission or to submit the matter to the competent authorities for investigation and prosecution.

There are a number of ongoing issues relating to the scope of the doctrine of command responsibility, both under the statutes of the tribunals and in customary international law. These are not addressed in detail here. ${ }^{628}$ A more relevant question concerns the structure of command responsibility. There are two basic schools of thought. ${ }^{629}$ On one interpretation, command responsibility is a mode of liability, such that the commander is held responsible for the wrongdoing of his subordinate. This view renders command responsibility akin to a rule of imputational complicity. In imputational systems, just as one's acts of instigation, abetment, or assistance give rise to criminal responsibility for the acts of a principal perpetrator, so the failure to prevent or punish the crimes of one's subordinates gives rise to criminal responsibility for those acts. On the second interpretation, liability is imposed for a separate offence of omission - the failure to prevent or punish the crimes committed by the subordinate.

\footnotetext{
${ }^{628}$ See Meloni, Command Responsibility; Martinez, 'Understanding Mens Rea in Command Responsibility'; Robinson, 'How Command Responsibility Got so Complicated'.

${ }^{629}$ Chantal Meloni, 'Command Responsibility: Mode of Liability for the Crimes of Subordinates or Separate Offence of the Superior?' (2007) 5 J. Intl Crim. Just. 619, 620. See also Darryl Robinson, 'How Command Responsibility Got So Complicated' 8.
} 


\subsubsection{Diverging Interpretations}

Both approaches are evident in the origins of the doctrine and early instances of codification, though there is a tendency towards command responsibility as a mode of liability. ${ }^{630}$ At the ICTY there are divergent holdings on this question, sometimes in the same judgment. In Halilović, the Trial Chamber stated:

[W] hether command responsibility is a mode of liability for the crimes of subordinates or responsibility of a commander for dereliction of duty has not been considered at length in the jurisprudence of the Tribunal. However, the consistent jurisprudence of the Tribunal has found that a commander is responsible for the crimes of his subordinates under Article 7(3). ${ }^{631}$

The finding that the commander is responsible for the crimes of his subordinates mirrors the language used by the ICTY Trial Chamber in Čelebići. ${ }^{632}$ Later on in Halilović, however, the Trial Chamber suggests that the commander does not 'share' responsibility with his subordinates but is responsible in 'proportion' to the gravity of the offences. ${ }^{633}$ Meloni suggests that this marks a shift in interpretation of command responsibility at the ICTY ${ }^{634}$ So in Orić, the Trial Chamber held that the 'superior cannot be considered as if he had committed the crime himself, but merely for his neglect of duty with regard to crimes committed by subordinates. ${ }^{635}$ The Appeals Chamber did not express a view on the matter, though Judge

\footnotetext{
${ }^{630}$ See Meloni, 'Command Responsibility: Mode of Liability?' 621-624; Robinson, 'How Command Responsibility Got So Complicated’ 33-34.

${ }^{631}$ Halilović (Trial Chamber Judgment) IT-01-48-T (16 November 2005) [53].

${ }^{632}$ Čelebići (Trial Chamber Judgment) [331].

${ }^{633}$ Halilović (Trial Chamber Judgment) [54].

${ }^{634}$ Meloni, 'Command Responsibility: Mode of Liability?' 625-626.

${ }^{635}$ Orić (Trial Chamber Judgment) [293].
} 
Shahabudeen reiterated his long-held view that the commander is responsible only for his omission. ${ }^{636}$

One emerging interpretation of the ICTY case law attempts to plot a middle course between command responsibility (i) as a mode of liability and (ii) as a substantive offence of omission. This interpretation emphasises the so-called sui generis nature of command responsibility. ${ }^{637}$ The commander is neither responsible solely for a separate offence of omission nor for the crimes committed by his subordinates. Rather, he is responsible for his own omission 'with regard to', 638 'in respect of ${ }^{639}$ or 'because of ${ }^{640}$ the crimes committed by his subordinates. ${ }^{641}$ This approach is evident in the sentencing of Naser Orić. Here, the Trial Chamber emphasised that the defendant was actually convicted of the "failure to prevent and punish' the crimes of his subordinates, and that his own failure and the gravity of the crimes committed by his subordinate were primary considerations in imposing sentence. $^{642}$

\footnotetext{
${ }^{636}$ Orić (Appeals Chamber Judgment) (Declaration of Judge Shahabudeen) [18]-[26]. See also Hadžihasanović, Alagić, Kubura (Appeals Chamber Decision on Interlocutory Appeal Challenging Jurisdiction in Relation to Command Responsibility) (Partially Dissenting Judgment of Judge Shahabudeen) IT-01-47-AR72 (16 July 2003). See also Krnojelac (Appeals Chamber Judgment) IT97-25-A (17 September 2003) [171].

${ }^{637}$ Halilović (Trial Chamber Judgment) [78]; Orić (Trial Chamber Judgment) [293]. See also Mettraux, The Law of Command Responsibility 80-81; Meloni, 'Command Responsibility: Mode of Liability?' 631.

${ }^{638}$ Orić (Trial Chamber Judgment) [293].

${ }^{639}$ Čelebići (Appeals Chamber Judgment) [225].

${ }^{640}$ Halilović (Trial Chamber Judgment) [54].

${ }^{641}$ See Mettraux, The Law of Command Responsibility 81; Robinson, 'How Command Responsibility Got So Complicated' 36-39.

${ }^{642}$ Orić (Trial Chamber Judgment) [724].
} 
There is an interesting parallel between this approach and non-imputational complicity rules. In a sense, non-imputational complicity rules may be seen as a middle ground between an entirely inchoate approach to help or influence in the commission of crime, under which liability is fixed at the moment the help or influence is given without regard to whether the principal offence is committed, and imputational rules that render the accomplice responsible for the principal's acts. Non-imputational complicity rules hold the accomplice responsible for her own acts of help or influence in respect of the principal's crime - so assisting murder or abetting robbery. Likewise, under the emerging approach to command responsibility, the superior is responsible for his own acts of omission but his responsibility for that omission is assessed with respect to the gravity of the principal crime.

The same issue of determining the nature of command responsibility arises in respect of Article 28 of the Rome Statute. Again, there are different approaches, evident in both academic commentary and in state parties' implementing legislation. ${ }^{643}$ In England and Wales, after setting out the text of Article 28, the International Criminal Court Act provides that a 'person responsible under this section for an offence is regarded as aiding, abetting, counselling or procuring the commission of the offence. ${ }^{644}$ This links command responsibility to the Accessories and Abettors Act of 1861, under which accomplices are indicted, tried, and punished

\footnotetext{
${ }^{643}$ Robert Cryer, 'General Principles of Liability in International Criminal Law' in Dominic McGoldrick, Peter Rowe and Eric Donnelly (eds), The Permanent International Criminal Court: Legal and Policy Issues (Hart 2004) 233, 258.

${ }^{644}$ International Criminal Court Act 2001 s 65(4). In respect of Scotland, see the International Criminal Court (Scotland) Act 2001, s 5.
} 
as principals. ${ }^{645}$ On the other hand, Canada's Crimes against Humanity and War Crimes Act contemplates a separate indictable offence of omission. ${ }^{646}$

In the academic commentary, Ambos argues that Article 28 is a separate crime of omission. On his reading, the superior is liable only for his own failure to act and not for the crimes committed by his subordinate. ${ }^{647}$ Schabas is less categorical, though does argue that command responsibility is 'a distinct crime whose gravamen is the failure to supervise or punish. ${ }^{, 648}$ Werle, on the other hand, argues that Article 28 is a subsidiary mode of participation in crime within the general scheme set out by the Statute. ${ }^{649}$ On this basis, the commander is liable for the crimes committed by his subordinates although, in keeping with the graded model of participation set out in Article 25, he is potentially liable to a lesser degree than direct or indirect perpetrators. ${ }^{650}$

As a matter of interpretation, Werle is probably correct. The language of Article 28 strongly suggests that command responsibility is not a separate crime of omission. In the first place, the introductory phrase positions command responsibility as a doctrine '[i]n addition to other grounds of criminal responsibility under this Statute for crimes within the jurisdiction of the Court... ${ }^{651}$ Secondly, the language specifically states that military commanders or other superiors 'shall be criminally

\footnotetext{
${ }^{645}$ Accessories and Abettors Act, s.8.

${ }^{646}$ Crimes against Humanity and War Crimes Act 2000, s 5 (Canada). See Cryer, 'General Principles of Liability' 258.

${ }^{647}$ Kai Ambos, 'Superior Responsibility' in Cassese et al (eds), The Rome Statute 805, 832-833.

${ }^{648}$ Schabas, A Commentary on the Rome Statute 457.

${ }^{649}$ Gerhard Werle, Principles of International Criminal Law (TMC Asser 2009) 189.

${ }^{650}$ Ibid.

${ }^{651}$ Art 28 Rome Statute (emphasis added).
} 
responsible for crimes within the jurisdiction of the Court committed by their' subordinates. This language is clear. ${ }^{652}$ Although the ICC has not directly addressed the debate concerning the nature of command responsibility, a natural interpretation of its decision in Bemba confirms that command responsibility is a mode of responsibility rather than a separate offence of omission:

The Chamber notes that article 28 of the Statute reflects a different form of criminal responsibility than that found under article 25(3)(a) of the Statute in the sense that a superior may be held responsible for the prohibited conduct of his subordinates for failing to fulfil his duty to prevent or repress their unlawful conduct or submit the matter to the competent authorities. $^{653}$

\subsubsection{Analysis}

While the nature of command responsibility at the ad hoc tribunals remains controversial and subject to fragmented decisions, under the Rome Statute such a failure to act will likely be a mode of participation in the crimes of the principal. Given the drafting of the Rome Statute, the superior will thus be responsible for the perpetrator's crimes. Understanding command responsibility as a separate offence or even a so-called 'sui generis' doctrine of responsibility, as has been suggested at the ad hoc tribunals, raises fewer principled concerns in terms of the foundational principle of culpability in criminal law. ${ }^{654}$ Although responsibility in this form may still be classified as derivative - there is no liability without the perpetration of the underlying crime $e^{655}$ - it is not imputational. The commander's own failure is the subject of prosecution with the seriousness of the underlying crime bearing on the

\footnotetext{
${ }^{652}$ See Robert Cryer, 'Command Responsibility at the ICC and ICTY: Two Minds on the Mental Element' (EJIL:Talk!, 20 July 2009) <http://www.ejiltalk.org/command-responsibility-at-the-icc-andicty-in-two-minds-on-the-mental-element/> accessed 23 July 2013. Cf Halilović (Trial Chamber Judgment) [54].

${ }^{653}$ Bemba (Decision on the Confirmation of Charges) ICC-01/05-01/08 (15 June 2009) [405]. See Robinson, 'How Command Responsibility Got So Complicated' 53-54.

${ }^{654}$ Robinson, 'How Command Responsibility Got So Complicated' 30-31.

${ }^{655}$ Mettraux, The Law of Command Responsibility 79-80.
} 
gravity of the commander's sentence. ${ }^{656}$

Principled concerns arise when the commander is held responsible for the acts of the subordinate. In assessing these principled concerns, it does not make sense to talk of a unitary doctrine of command responsibility. ${ }^{657}$ Under the Rome Statute, command responsibility involves three different duties that may be coupled with three different mental states. ${ }^{658}$ The three duties are duties to prevent, repress, and submit the matter to competent authorities for investigation and prosecution. These duties are discrete and arise at different stages of the commission of crimes by the subordinate. ${ }^{659}$ The duty to prevent arises prior to the commission of crimes. ${ }^{660}$ The duty to repress comprises two separate elements: an obligation to stop ongoing crimes and an obligation to punish forces after the commission of crimes. ${ }^{661}$ And the duty to submit requires that the commander take steps to ensure that the perpetrators are brought to justice. $^{662}$

For both civilian and military superiors, actual knowledge of the crimes committed will give rise to liability. Such actual knowledge must be demonstrated by direct or circumstantial evidence. ${ }^{663}$ In addition, for military commanders, liability may also arise where, owing to the circumstances at the time, they should have known

\footnotetext{
${ }^{656}$ Orić (Trial Chamber Judgment) [727].

${ }^{657}$ Meloni, Command Responsibility 145.

${ }^{658}$ For a more detailed analysis of the elements, see Meloni, Command Responsibility 139-207.

${ }^{659}$ Bemba (Decision on the Confirmation of Charges) [436].

${ }^{660}$ Ibid [437].

${ }^{661}$ Ibid [439].

${ }^{662}$ Ibid [442].

${ }^{663}$ Ibid [430].
} 
that the forces were committing or about to commit crimes. ${ }^{664}$ This standard involves an active duty to take measures to obtain knowledge about the conduct of troops under their command. ${ }^{665}$ Under the Rome Statute at least, for civilian superiors the standard is higher, requiring a conscious disregard of information that clearly indicated that crimes were being committed. This is a standard of gross recklessness or wilful blindness. ${ }^{666}$

For the purposes of a more general analysis, the duty to prevent may be grouped with the first element of the duty to repress - the obligation to stop ongoing crimes. Likewise, the second element of the duty to repress - the obligation to punish perpetrators - may be grouped with the duty to submit the matter for investigation and prosecution. In addition, focus will be placed on the standard binding military superiors set out in the Rome Statute rather than that binding civilians. For analytical purposes, this leaves four kinds of violation:

A. Failure to prevent or stop the commission of crimes with actual knowledge of their commission;

B. Failure to prevent or stop the commission of crimes where the commander should have known of their commission;

C. Failure to punish perpetrators or submit crimes for investigation with actual knowledge of their commission; and

D. Failure to punish perpetrators or submit crimes for investigation where the commander should have known of their commission. ${ }^{667}$

\footnotetext{
${ }^{664}$ Art 28(1)(a) Rome Statute; Art 7(3) ICTY Statute; Čelebići (Trial Chamber Judgment) [346]. The Rome Statute standard of 'should have known' may entail a small difference from the standard of 'had reason to know' at the tribunals. See Martinez, 'Understanding Mens Rea in Command Responsibility' 642; Robinson, 'How Command Responsibility Got So Complicated' 8.

${ }^{665}$ Bemba (Decision on the Confirmation of Charges) [433].

${ }^{666}$ See Schabas, A Commentary on the Rome Statute 463.

${ }^{667}$ This analytical structure is equivalent to the two-fold obligation of prevent and punish. See Mettraux, The Law of Command Responsibility 229-234. See also Meloni, Command Responsibility 196-204.
} 
One complication is that categories A through D specify quite different kinds of culpability. ${ }^{668}$ This point is illustrated by reference to complicity. Category Aknowing failure to prevent the commission of crimes in breach of a duty to do somay be considered aiding and abetting by omission. ${ }^{669}$ Indeed, Category A adds little to an ordinary conception of complicity. ${ }^{670}$ It establishes a general rule that such a failure helps or encourages the conduct of the subordinate.

Likewise, Category B — failure to prevent the crime where the superior should have known about its commission — may also be seen as helping or encouraging the conduct of the subordinate. As in Category A, there is causal relationship between the omission and the harm. ${ }^{671}$ However, in contrast to the intentionality of his wrongdoing in Category A, it is only required that the superior in Category B should have known about his subordinate's wrongdoing. A standard of 'should have known' encompasses a range of mental states. ${ }^{672}$ At one end of the spectrum there is a 'scheming superior who condones the delinquency of his underlings and engineers his own ignorance' of their plans. ${ }^{673}$ In such situations, concern about the reduced mental element are somewhat diminished. Wilful blindness and intentional wrongdoing are not too far apart. ${ }^{674}$

\footnotetext{
${ }^{668}$ Cryer, 'General Principles of Liability' 258-259.

${ }^{669}$ Meloni, Command Responsibility 198.

${ }^{670}$ Damaška, 'The Shadow Side of Command Responsibility' 462; 'Robinson, 'How Command Responsibility Got So Complicated' 8.

${ }^{671}$ See Bemba (Decision on the Confirmation of Charges) [423].

${ }^{672}$ Damaška, 'The Shadow Side of Command Responsibility' 462.

673 Ibid.

${ }^{674}$ Ibid.
} 
But a standard of 'should have known' is one encompassing a species of negligence. ${ }^{675}$ In essence, category B establishes a rule of negligent complicity. The violation of the principle of culpability is obvious. Given the structure of Article 28, and the fact that the crimes within the jurisdiction of the court require intention, under category B the commander is held liable for an intentional offence on the basis of his own negligence in failing to prevent its commission. ${ }^{676}$ As Damaška puts it, 'Sub silentio, as it were, a negligent omission has been transformed into intentional criminality of the most serious nature... ${ }^{677}$ In this way, command responsibility establishes a 'special form of incrimination' particular to international law, said to be justified by the ability of commanders to prevent wrongdoing. ${ }^{678}$

Thus in the form envisaged by the Rome Statute, the doctrines of command responsibility denoted by categories $\mathrm{A}$ and $\mathrm{B}$ are subject to criticism. Category $\mathrm{A}$ is best thought of as a form of complicity by omission, and on these terms is open to the normative argument of this thesis against complicity rules that hold accomplices responsible for the acts of their principals. This principled objection is magnified in respect of category B. Here, not only does negligent omission give rise to responsibility for another's acts, but also gives rise to responsibility for intentional crimes where the superior did not act intentionally.

\footnotetext{
${ }^{675}$ Meloni, 'Command Responsibility: Mode of Liability?' 634; Damaška, 'The Shadow Side of Command Responsibility’ 463; Bemba (Decision on the Confirmation of Charges) 429.

${ }^{676}$ Meloni, 'Command Responsibility: Mode of Liability?' 635-636.

${ }^{677}$ Damaška, 'The Shadow Side of Command Responsibility’ 463-464.

${ }^{678}$ Robert Cryer, Prosecuting International Crimes: Selectivity and the International Criminal Law Regime (CUP 2005) 316. For recent work on possible justifications for a standard of mens rea lower than knowledge for command responsibility, see Martinez, 'Understanding Mens Rea in Command Responsibility' 660-664.
} 
Categories $\mathrm{C}$ and $\mathrm{D}$ - intentional and negligent failures to punish the crimes of subordinates - are subject to the same objections but are also problematic in an additional way. A failure to punish can have no causal effect on the preceding commission of crimes. ${ }^{679}$ In other words, it can make no contribution to that crime. Of course, such a failure may encourage the subsequent commission of crimes by subordinates and thereby give rise to aiding and abetting liability for those crimes. ${ }^{60}$ But subsequent failures can in no way assist or encourage the initial crimes. The imposition of criminal responsibility in the absence of a causal nexus is rarely justifiable. ${ }^{681}$ Here, superiors are being held responsible for crimes in which they did not participate at all.

Robinson denies that this problem of non-contributory command responsibility under categories $\mathrm{C}$ and $\mathrm{D}$ arises under the Rome Statute. In a recent article, he argues that the Rome Statute does not, as a matter of textual interpretation, provide for the responsibility of commanders in the absence of a causal contribution to subordinate's crimes. ${ }^{682}$ This is because of the language of Article 28:

(a) A military commander or person effectively acting as a military commander shall be criminally responsible for crimes within the jurisdiction of the Court committed by forces under his or her effective command and control, or effective authority and control as the case may be, as a result of his or her failure to exercise control properly over such forces, where:

(i) That military commander or person either knew or, owing to the circumstances at the time, should have known that

\footnotetext{
${ }^{679}$ Bemba (Decision on the Confirmation of Charges [424]. See also Meloni, 'Command Responsibility: Mode of Liability?' 636.

${ }^{680}$ Damaška, 'The Shadow Side of Command Responsibility' 467; Robinson, 'How Command Responsibility Got So Complicated' 16-17.

${ }^{681}$ Ilias Bantekas, 'On Stretching the Boundaries of Responsible Command' (2009) 7 J. Intl Crim. Just. 1197, 1199; Robinson, 'How Command Responsibility Got So Complicated’ 12-13.

${ }^{682}$ Robinson, 'How Command Responsibility Got So Complicated' 56-57.
} 
the forces were committing or about to commit such crimes; and

(ii) That military commander or person failed to take all necessary and reasonable measures within his or her power to prevent or repress their commission or to submit the matter to the competent authorities for investigation and prosecution. $^{683}$

This is a complicated question of interpretation that need not be resolved for the purposes of this thesis. Robinson's position does draw support from the text, not only from the italicised clause above, but also from the grammar of Article 28(a)(i). On the other hand, other than in respect of the subsequent commission of crimes, Robinson's interpretation would render criminal responsibility based on the wellestablished customary law obligation of commanders to punish the crimes of their subordinates a dead letter. ${ }^{684}$ When responsibility is based on a failure to punish a crime, it makes no sense to additionally require that the crime itself occurred as a result of the commander's failure to exercise control. ${ }^{65}$ This is the view of the ICC Pre-Trial Chamber in Bemba: 'the element of causality only relates to the commander's duty to prevent the commission of future crimes. ${ }^{, 686}$

\subsubsection{Command Responsibility and Complicity: Conclusion}

The doctrine of command responsibility comprises quite different forms of responsibility. The gravest conduct encompassed therein-knowing failure to prevent the commission of crimes - may be considered a form of complicity by omission. It may be justified in those terms, though it will be subject to the normative argument against holding accomplices responsible for their principal's acts. Failure to prevent

\footnotetext{
${ }^{683}$ Art 28(a) Rome Statute (emphasis added).

${ }^{684}$ Cf Robinson, 'How Command Responsibility Got So Complicated' 27-29.

${ }^{685}$ Orić (Trial Chamber Judgment) [338].

${ }^{686}$ Bemba (Decision on the Confirmation of Charges) [424] (emphasis added).
} 
crimes when the commander should have known about their commission is a form of negligent complicity by omission. Negligence should not give rise to responsibility for intentional crimes. Command responsibility founded on a failure to punish wrongdoing gives rise to responsibility for crimes to which the superior bears no causal relation.

These principled objections disappear if command responsibility were recognised to give rise to responsibility for separate crime defined by the superior's own acts. Superiors ought to be responsible for their own acts of omission, the gravity of which may be assessed by reference to the underlying crime. Those who negligently fail to prevent their subordinates from committing crimes would be responsible for exactly that, as would those who either intentionally or negligently fail to punish those crimes. Intentional failure to prevent the crimes of a subordinate could be cleaved from the doctrine of command responsibility and assessed as a form of complicit omission.

\subsection{CONCLUSION}

The central means by which international law prohibits individual complicity in international crimes are the doctrines instigation and aiding and abetting. International criminal law embraces a doctrinally differentiated model of participation in crime- in respect of complicity, instigation and aiding and abetting have their own doctrinal requirements. However, in the post-Second World War cases, at the ad hoc tribunals, and under the Rome Statute, the language of the provisions on international responsibility render each of those nominally differentiated participants responsible for the underlying crime. That is to say, someone who instigates or aids and abets 
genocide is responsible for the crime of genocide, the crime committed by the principal. This approach is open to objection on the basis of the principles of culpability and fair labelling. In terms of punishment, international courts have a degree of discretion to take into account varying degrees of participation at sentencing.

In the next chapter, this structure of complicity will be contrasted with the dominant approach to state complicity in international law. The rule reflected in Article 16 ARSIWA prohibits states from aiding or assisting other states in the commission of an internationally wrongful act. ${ }^{67}$ Under this rule, the assisting state is held to be responsible for its own acts of assistance. ${ }^{68}$ That is to say, the conduct of the principal state is not imputed to the accomplice state. This model of complicity should be preferred on principled grounds.

Leaving aside that principled concern, it is clear that international criminal law's approach to complicity is marked by the breadth of the forms of complicity prohibited, a standard of knowledge on the part of the accomplice, and an underused nexus requirement connecting the accomplice to the principal's wrong. These are the hallmarks of individual complicity in international law. Complicit omissions are accounted for through the doctrine of aiding and abetting and as a form of command responsibility.

\footnotetext{
${ }^{687}$ Art 16 ARSIWA.

${ }^{688}$ ARSIWA Commentary on Art 16 [10].
} 


\section{Part C. STate Complicity in InTERnational LaW}

\section{CHAPTER 6. STATE COMPLICITY - A FRAMEWORK}

\subsection{State Complicity in State Wrongdoing}

Historically, international law failed to adequately regulate state complicity in the wrongdoing of other states. In his Hague Lectures of 1939, Ago argued that:

[I]t appears that international law does not conceive of any form of complicity, participation, or incitement to a delict. The law of nations, in its current structure, does not allow for such forms of a consideration shared by several subjects with respect to a single delict; these constructs are characteristic of the nature and development of domestic criminal law. ${ }^{689}$

One way to understand the traditional absence of a general prohibition on state complicity is within the competing constructs of bilateralism and community interest. ${ }^{690}$ In this context, bilateralism engenders an understanding of international law defined by correlative rights and obligations owed by subjects to each other. ${ }^{691}$ The participation of third states - that is to say, the complicity of third states - in the breach of obligations owed by one state to another might be said to be difficult to account for within a bilateralist framework. ${ }^{692}$ There is something to this view. These difficulties are heightened at the stage of dispute settlement, where the Monetary Gold principle may limit the admissibility of claims for responsibility. ${ }^{693}$ The non-prohibition of complicity epitomises what Bruno Simma has called the

\footnotetext{
${ }^{689}$ Roberto Ago, 'Le Délit International' (1939) 68 (II) Recueil des Cours 419, 523 (translated). See also Aust, Complicity in the Law of State Responsibility 12.

${ }^{690}$ Aust, Complicity in the Law of State Responsibility 11-49. See also Bruno Simma, 'From Bilateralism to Community Interest in International Law' (1994) 250 Recueil des Cours 217, 229-255.

${ }^{691}$ Simma, From Bilateralism to Community Interest 231-232.

${ }^{692}$ See Aust, Complicity in the Law of State Responsibility 12-15. Aust seeks to look beyond an analysis based on bilateralism and community interest in accounting for the development of complicity in the law of state responsibility.

${ }^{693}$ Case of the Monetary Gold Removed from Rome in 1943 (Italy v France, United Kingdom and United States of America) (Preliminary Question) [1954] ICJ Rep 19. See also East Timor (Portugal v Australia) [1995] ICJ Rep 90; Ch. 7.3.8 below.
} 
'value-poverty of bilateralist international law. ${ }^{694}$ It is insufficient that states concern themselves only with the wrongs they commit themselves. ${ }^{695}$

But even within a traditional bilateralist framework, ideas of complicity and its kindred forms of responsibility played a role. ${ }^{696}$ One example is the law of neutrality. Neutrality regulates the relationship between neutral states and belligerents through the core principles of non-participation and non-discrimination. ${ }^{697}$ The principle of non-participation gives rise to a number of duties that are related to forms of complicity. ${ }^{698}$ For instance, Article 6 of the Hague Convention concerning the Rights and Duties of Neutral Powers in Naval War provides that ' $[t]$ he supply, in any manner, directly or indirectly, by a neutral Power to a belligerent Power, of war-ships, ammunition, or war material of any kind whatever, is forbidden. ${ }^{699}$ Neutrality also prescribes extensive rules on the use of neutral powers' territory by belligerents. ${ }^{700}$ The point is not that breach of the rule of non-participation gives rise to a form of derivative responsibility in respect of a subsequent wrong of the belligerent. Rather, the law of neutrality entails an instance where obligations of third states arise and are implicated by the conduct of other states.

To some extent, a traditional understanding of the law of neutrality is premised on the permissibility of war. For this reason, it has been affected by the rise

\footnotetext{
${ }^{694}$ Simma, From Bilateralism to Community Interest 233.

${ }^{695}$ Lowe, 'Responsibility for the Conduct of Other States' 13.

${ }^{696}$ See Aust, Complicity in the Law of State Responsibility 15-23.

${ }^{697}$ Yoram Dinstein, War, Aggression and Self-Defence $\left(5^{\text {th }}\right.$ ed. CUP 2011) 25.

${ }^{698}$ See Lowe, 'Responsibility for the Conduct of Other States' 13.

${ }^{699}$ Art 6 Convention concerning the Rights and Duties of Neutral Powers in Naval War (adopted 18 October 1907, entered into force 26 January 1910) 36 Stat. 2415.

${ }^{700}$ See Dinstein, War, Aggression and Self-Defence 26-27.
} 
of the Charter system of collective security and the prohibition on the use of force in international law. ${ }^{701}$ Interestingly, the Charter system sets out a rule much closer in rationale to that of a prohibition on complicity. Article 2(5) of the Charter requires that ' $[\mathrm{A}] 11 \mathrm{Members}$... refrain from giving assistance to any state against which the United Nations is taking preventive or enforcement action. ${ }^{702}$ Complicity entails participation in wrongdoing. The decision of the Security Council to take preventive or enforcement action both triggers member states' obligations of non-assistance and, in some instances, entails a (political, at least) determination of wrongful conduct by the aggressor state. ${ }^{703}$

Leaving aside the law of neutrality and changes brought by the Charter system, Ago's general point about the traditional absence of complicity rules is accurate. International law traditionally contained no general prohibition on state complicity in the internationally wrongful act of another state - there was no international analogue to common domestic doctrines of accomplice or accessorial liability. ${ }^{704}$ Short of joint perpetration, as a general rule, participants in another state's commission of an internationally wrongful act were not implicated by international law's assignment of responsibility.

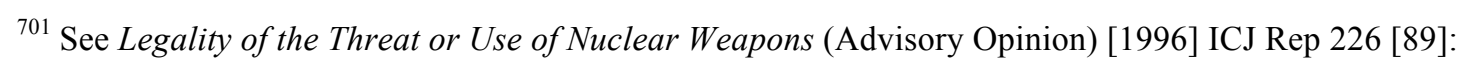

[I]nternational law leaves no doubt that the principle of neutrality, whatever its content, which is of a fundamental character similar to that of the humanitarian principles and rules, is applicable (subject to the relevant provisions of the United Nations Charter), to all international armed conflict. (emphasis added).

See Dinstein, War, Aggression and Self-Defence 176-180.

${ }^{702}$ Art 2(5) Charter of the United Nations (adopted 26 June 1945, entered into force 25 October 1945) 1 UNTS XVI.

${ }^{703}$ See Dinstein, War, Aggression and Self-Defence 176. See also Aust, Complicity in the Law of State Responsibility 158-162 for discussion of United Nations resolutions relating to non-assistance.

${ }^{704}$ See Quigley, 'Complicity in International Law' 77. 


\subsection{State Participation In the Acts of Non-State Actors - A CONCEPTUAL}

\section{DIFFICULTY FOR COMPLICITY}

Participating in wrongful acts of other states is not the only way that states contribute to harmful conduct. Non-state actors commit acts inimical to the rights and interests of both states and individuals. States sometimes participate in those acts. With a sufficient degree of dependence, direction, or control, the conduct of the non-state actor becomes attributable to the state. ${ }^{705}$ As argued below, the requisite connection between the state and non-state actor for attribution is marked by a search for an agency relationship. ${ }^{706}$ In the absence of lex specialis, a complicit relationship is insufficient for attribution.

Short of such an agency relationship, the question is whether international law imposes complicity obligations on states in respect of the conduct of non-state actors. Here, there is a conceptual difficulty for a study of complicity. The essential logic of complicity is to tie the accomplice, through its complicit acts, to the wrongdoing committed by another actor. ${ }^{707}$ Where international law is silent as to the wrongfulness of the acts committed by the other actor, it is difficult to see what wrong the putative accomplice can be complicit in. ${ }^{708}$ This problem flows from the essential derivative nature of complicity. ${ }^{709}$

\footnotetext{
${ }^{705}$ Arts 4, 8 ARSIWA.

${ }^{706}$ See Ch. 8.2 below; Becker, Terrorism and the State 43-79.

${ }^{707}$ Kadish, 'Complicity, Cause and Blame' 337.

${ }^{708}$ De Frouville, 'Attribution of Conduct' 276.

${ }^{709}$ See Ch. 1.1 above. See also Becker, Terrorism and the State 19.
} 
This conceptual difficulty is but one implication of the traditional normative structure of the international legal system. ${ }^{710}$ Historically, international law was addressed to states, and indeed states remain the primary bearers of rights and obligations in international law. ${ }^{711}$ The absence of regulation of the conduct of nonstate actors simply denied the possibility of state complicity in relation to that conduct, for there was no wrong to which the state might be linked by the complicity rule.

This is not to say that international law is silent on state participation-short of attribution - in harms caused by another actor. In a number of areas, international law does impose what might be called obligations of non-participation, as opposed to complicity obligations, in the actions of another actor. For instance, as elements of the principle of the non-use of force, the General Assembly's Declaration on Friendly Relations, adopted unanimously in 1970, provides:

Every State has the duty to refrain from organizing or encouraging the organization of irregular forces or armed bands, including mercenaries, for incursion into the territory of another State.

Every State has the duty to refrain from organizing, instigating, assisting or participating in acts of civil strife or terrorist acts in another State or acquiescing in organized activities within its territory directed towards the commission of such acts, when the acts referred to in the present paragraph involve a threat or use of force. ${ }^{712}$

These provisions, which reflect customary international law, ${ }^{713}$ might be seen as analogous to traditional duties of neutrality. Just as the violation of the duty of

\footnotetext{
${ }^{710}$ De Frouville, 'Attribution of Conduct' 276.

${ }^{711}$ Robert Jennings and Arthur Watts, Oppenheim 's International Law - Volume 1: Peace $\left(9^{\text {th }}\right.$ ed, Longman 1996) 16; Crawford, Brownlie's Principles of Public International Law 115.

${ }^{712}$ UNGA Res 2625 (XXV) (24 October 1970) (Declaration on Friendly Relations).

${ }^{713}$ Armed Activities on the Territory of the Congo (Democratic Republic of Congo $v$ Uganda) (Merits) [2005] ICJ Rep 168 [162].
} 
neutrality does not give rise to a form of derivative responsibility in relation to some wrongful act of the belligerent state, so the participation by the state does not give rise to derivative responsibility in relation to some wrongful act of the armed band. In both cases, the state's responsibility for its wrongful participation is not linked to any wrong of a principal actor. ${ }^{714}$ Instead, a number of classic modes of complicity are used to constitute a direct and independent obligation of non-participation binding the state. $^{715}$

In addition, many instances of state participation in the harms caused by nonstate actors are swept up by broader positive obligations imposed on states to protect against harms to other states or individuals. ${ }^{716}$ The obligation on states to protect against harm is ordinarily conditioned by a due diligence rule, and thus may give rise to state responsibility where the state did not actually participate in the commission of the harm. $^{717}$

\footnotetext{
${ }^{714}$ For a general discussion, see Ian Brownlie, 'International Law and the Activities of Armed Bands' (1958) 7 ICLQ 712; Thomas Franck, 'Who Killed Article 2(4)? Or: Changing Norms Governing the Use of Force by States' (1970) 64 Am. J. Intl L. 809.

${ }^{715}$ In respect of state participation in terrorism, see e.g. UNSC Res 1373 (28 September 2001) UN Doc S/RES/1373; UNGA Res 40/61 (9 December 1985) UN Doc A/RES/40/61; UNGA Res 44/29 (4 December 1989) UN Doc A/RES/44/29; UNGA Res 49/60 (9 December 1994) UN Doc A/RES/49/60; UNGA Res 51/210 (17 December 1996) UN Doc A/RES 51/210; UNGA Res 53/108 (26 January 1999) UN Doc A/RES/53/108. See also Eric Rosand, 'Security Council Resolution 1373, the CounterTerrorism Committee and the Fight Against Terrorism' (2003) 97 Am. J. Intl L. 333; Andrea Bianchi, 'Enforcing International Law Norms against Terrorism: Achievements and Prospects' in Andrea Bianchi (ed.), Enforcing International Law Norms against Terrorism (Hart 2004) 491; Pierre-Marie Dupuy, 'State Sponsors of Terrorism: Issues of International Responsibility' in Bianchi (ed.), Enforcing International Law Norms against Terrorism 3; Ben Saul, Defining Terrorism in International Law (OUP 2006).

${ }^{716}$ See generally Pisillo-Mazzeschi, 'Due Diligence'; Barnidge, The Due Diligence Principle under International Law.

${ }^{717}$ See Monica Hakimi, ‘State Bystander Responsibility' (2010) Eur. J. Intl L. 341; Olivier Corten and Pierre Klein, 'The Limits of Complicity as a Ground of Responsibility: Lessons Learned from the Corfu Channel Case' in Bannelier et al (eds), The ICJ and the Evolution of International Law 315.
} 
Obligations of this kind are often traced to international law's regulation of the treatment of non-nationals. ${ }^{718}$ In the Spanish Zone of Morocco arbitration, Max Huber held that:

... the State is not responsible for the revolutionary events themselves... it may nevertheless be responsible for what the authorities do or do not do to mitigate the consequences as far as possible. Responsibility for the action or inaction of the public authorities is quite different from the responsibility for acts that may be imputed to persons outside the control of the authorities or openly hostile to them. ${ }^{719}$

The obligation to protect against harms to aliens, as a primary rule of international law, is well established. ${ }^{720}$ The nature of the obligation is revealed in diplomatic correspondence between the Italian and United States governments after the destruction of property belonging to a US citizen in Italy in $1925:^{721}$ ' [Italy] holds itself obligated, not absolutely to prevent certain occurrences from taking place, but to exercise in order to obviate them ordinary vigilance for the protection of foreigners and citizens alike... ${ }^{722}$ Lillich and Paxman explain that the Department of State accepted this position and informed its Embassy in Italy that a claim ought to be pursued only if it could be shown that 'the authorities had knowledge, or should have had knowledge of the impending attack and failed to take proper precautions to thwart it... ${ }^{, 723}$

\footnotetext{
${ }^{718}$ See Richard Lillich and John Paxman, 'State Responsibility for Injuries to Aliens Occasioned by Terrorist Activities’ (1977) 26 Am. Univ. L. Rev. 217.

${ }^{719}$ Spanish Zone of Morocco Case (United Kingdom/Spain) (1923) 2 RIAA 615, 641-42.

${ }^{720}$ See Becker, Terrorism and the State 24-42; Lillich and Paxman, 'State Responsibility' 222-231.

${ }^{721}$ Lillich and Paxman, 'State Responsibility' 226.

${ }^{722}$ Hackworth, Digest of International Law 5 (1943) 659.

${ }^{723}$ Lillich and Paxman, 'State Responsibility’ 227 citing Hackworth 660-661.
} 
The obligation to protect against harm to aliens may be thought of as a specific iteration of a more general principle flowing from the territorial sovereignty of the state. In the Island of Palmas arbitration, Huber expressed the principle in exactly these terms:

Territorial sovereignty, as has already been said, involves the exclusive right to display the activities of a State. This right has as corollary a duty: the obligation to protect within the territory the right of other States, in particular their right to integrity and inviolability in peace and in war, together with the rights which each State may claim for its nationals in foreign territory. ${ }^{724}$

In the Corfu Channel case, Albania's responsibility was engaged on the basis of its failure to warn the UK of the existence of a minefield in Albanian territorial waters - every state was under an 'obligation not to allow knowingly its territory to be used for acts contrary to the rights of other states. ${ }^{725}$ A due diligence obligation to protect against certain harms is central to modern international environmental law ${ }^{726}$ and international human rights law. ${ }^{727}$ In the Bosnian Genocide case, Serbia's international responsibility was engaged for failing to prevent the genocide at Srebrenica. ${ }^{728}$ The obligation is one of conduct, not result, and requires the state to exercise due diligence in taking all means reasonably available to prevent the harm from occurring. ${ }^{729}$

\footnotetext{
${ }^{724}$ Island of Palmas (Netherlands/USA) (1928) 2 RIAA 829, 839.

${ }^{725}$ Corfu Channel (United Kingdom v Albania) (Merits) [1949] ICJ Rep 4, 22. See also United States Diplomatic and Consular Staff in Tehran (United States of America v Iran) (Merits) [1980] ICJ Rep 3; Luigi Condorelli, 'The Imputability to States of Acts of International Terrorism' (1989) 19 Isr. YB Human Rights 233, 240-241.

${ }^{726}$ See Trail Smelter (United States of America/Canada) 3 RIAA 1911; Karine Bannelier, 'Foundational Judgment or Constructive Myth? The Court's Decision as a Precursor to International Environmental Law' in Bannelier et al (eds.), The ICJ and the Evolution of International Law 242.

${ }^{727}$ See generally UNHRC, 'General Comment 31' (29 March 2004) UN Doc CCPR/C/21/Rev.1/Add.13 (2004) [6]-[8]; Velasquez Rodriguez (29 July 1988) Inter-Am.Ct.H.R. (Ser. C) No. 4 (1988) [161]-[167]; Ireland v United Kingdom (App 5310/71) (1978) 2 EHRR 25 [239].

${ }^{728}$ Bosnian Genocide [438].

${ }^{729}$ Bosnian Genocide [430].
} 
It is clear, then, that obligations of due diligence to prevent harm arise in many areas of international law. In some instances where the state has participated in the commission of harm, it will have breached the broader obligation to prevent that harm from occurring. ${ }^{730}$ So if Turkey intentionally provides information to a non-state actor in Turkey that facilitates the latter's killing of a journalist, it will be responsible for failing to protect the right to life under Article 2 of the European Convention on Human Rights. ${ }^{731}$ If Serbia intentionally provides logistical support to a non-state actor that facilitates the commission of genocide by that actor, its responsibility for failing to prevent genocide would certainly be engaged. ${ }^{732}$

\subsection{The Role of CoMPlicity?}

If these obligations of prevention are so capacious as to encompass many situations in which a state participates in the conduct of another actor, why should a study of international law pay attention to the idea of state complicity? ${ }^{733}$ There are three reasons. First, as a matter of positive law, international law does impose certain complicity obligations on states. States and other actors articulate the responsibility of other states in terms of their complicity rather than simply their failure to exercise due diligence in preventing harms from arising.

\footnotetext{
${ }^{730}$ See Corten and Klein, 'The Limits of Complicity' 332-333; Lillich and Paxman, 'State Responsibility' 237.

${ }^{731}$ Cf Kiliç v Turkey (App 22492/93) (2000) 33 EHRR 1357.

${ }^{732}$ See Bosnian Genocide [382]:

If a State is held responsible for [complicity in genocide] then there is no point in asking whether it complied with its obligation of prevention in respect of the same acts, because logic dictates that a State cannot have satisfied an obligation to prevent genocide in which it actively participated.

${ }^{733}$ See Corten and Klein, 'The Limits of Complicity' 332-333.
} 
Second, it is not yet the case that all forms of state participation in the wrongful actions of another state or non-state actor will breach a due diligence obligation to protect against harm to other states or individuals. ${ }^{734}$ Despite the development of due diligence obligations of this kind, they largely retain their territorial character. ${ }^{735}$ Imagine that State A, with full knowledge of the circumstances, provides a credit guarantee for one of its companies' participation in a project carried out in and by State B. ${ }^{736}$ The project constitutes an internationally wrongful act by State B, such as a violation of its obligations to protect cultural property. ${ }^{737}$ It is not clear that the responsibility of the assisting state would be engaged under an existing obligation to protect against harm to cultural property. In the absence of a complicity rule, State A's contribution to an internationally wrongful act would not engage its responsibility.

The third reason for paying attention to complicity goes beyond the confines of positive law. The absence of complicity rules in international law marks a lack of sophistication in the legal system. ${ }^{738}$ In Chapter 2 , it was argued that complicity is a particular mode of wrongdoing. This is why the language of complicity is

\footnotetext{
${ }^{734}$ Daniele Amoroso, 'Moving Towards Complicity as a Criterion of Attribution of Private Conducts: Imputation to States of Corporate Abuses in the US Case Law' (2011) 24 Leiden J. Intl L. 989, 992. Cf Corten and Klein, 'The Limits of Complicity' 332-333.

${ }^{735}$ See Island of Palmas; Vladyslav Lanovoy, 'Responsibility for Complicity in an Internationally Wrongful Act: Revisiting a Structural Norm' (SHARES Conference - Foundations of Shared Responsibility in International Law, Amsterdam, 17, 18 November 2011) 1, 7; Heathcote, 'State Omissions and Due Diligence' 297-299. Obligations of this kind may also arise where the state exercises effective control or jurisdiction over territory. See Legal Consequences for States of the Continued Presence of South Africa in Namibia (South West Africa) notwithstanding Security Council Resolution 276 (1970) (Advisory Opinion) [1971] ICJ Rep 16 [118]; Condorelli, 'Imputability to States' 240-241.

${ }^{736}$ See Lowe, 'Responsibility for the Conduct of Other States' 6.

${ }^{737}$ Ibid.

${ }^{738}$ Ibid 13.
} 
compelling: ${ }^{739}$ it articulates and condemns a common way that states and individuals contribute to wrongdoing. It is not a judgment that the individual or state committed the wrong, itself or through its agents. ${ }^{740}$ Neither is it a judgment that the individual or state simply failed to take reasonable measures to protect against the harm. ${ }^{741}$

Rather, it responds to complicity as a mode of wrongdoing - 'making a difference to the difference that principals make. ${ }^{, 74}$

\subsection{The Structure of PART C OF THE THESIS}

Part $\mathrm{C}$ of the thesis - comprising this Chapter and Chapters 7, 8, and 9-is concerned with the complicity obligations that international law imposes on states. Chapter 7 addresses a specific rule and a general rule prohibiting state complicity in the wrongful acts of other states. It positions these rules within the analytical framework of the thesis and evaluates them against the normative claim set out in Chapter 2. International law now prohibits states from aiding or assisting another state in the commission of an internationally wrongful act. This is an international analogue to municipal doctrines of accomplice liability.

Chapters 8 and 9 assess two ways that international law has dealt with the conceptual difficulty noted above concerning state participation in the harms caused by non-state actors. To recap, the conceptual difficulty is that in a system where

\footnotetext{
${ }^{739}$ Aust, Complicity in the Law of State Responsibility 418.

${ }^{740}$ See Ago, 'Seventh Report on State Responsibility' [57].

${ }^{741}$ On this point, see e.g. Antonio Cassese, 'A Judicial Massacre' The Guardian (London, 27 February 2007) describing the ICJ's finding that Serbia was responsible for failing to take reasonable measures to prevent genocide from occurring, but not responsible for genocide or complicity in genocide, as a 'consolation prize.' See also contemporaneous newspaper headlines, e.g. Beti Bilandzic and Nedim Dervisbegovic, 'Serbs Relieved, Bosnia Dismayed by Genocide Ruling' Reuters (Sarajevo, 26 February 2007); 'Court Clears Serbia of Genocide’ BBC News (London, 26 February 2007).

${ }^{742}$ Gardner, 'Complicity and Causality' 128.
} 
norms are addressed to states, there is no international legal wrong committed by the non-state actor. ${ }^{743}$ Although state participation in that conduct may be (and sometimes is) prohibited directly, the conceptual possibility for derivative responsibility based on complicity is foreclosed. There is simply no wrong in which the participating state might be complicit.

International law has responded in two quite different ways to this difficulty. Chapter 8 considers the claim that complicity has penetrated the rules of attribution in international law. The idea here is not quite like the operation of a complicity rule, as defined in Chapter 2, where the complicit party is linked to the wrongdoing of another actor. Rather, the attributional idea posits that a complicit relationship is sufficient to transform the conduct of the non-state actor into state conduct. It is not that the state is held derivatively responsible in relation to another actor's wrongdoing; rather, the conduct of that other actor becomes state conduct on the basis of its acts of support or assistance. Claims of this kind are open to principled objection and should be rejected.

Chapter 9 considers a second way that the conceptual difficulty noted above has been addressed. The conceptual difficulty is premised on the absence of legal regulation of the conduct of non-state actors. Of course, international law no longer imposes obligations only on states: individuals and other non-state actors have rights and obligations in international law. Once it is recognised that a non-state actor can violate international law, it becomes possible that a state might be complicit in that wrongdoing. Chapter 9 considers the prohibition on state complicity in genocide and

\footnotetext{
${ }^{743}$ See De Frouville, 'Attribution of Conduct' 712.
} 
raises the possibility that a non-state analogue to the general prohibition on state complicity in the wrongdoing of other states will emerge.

Together, these chapters - Part C - analyse different ways that international law deals with state complicity. The story is one of an increasing recognition of complicity as a particular way that states contribute to wrongdoing. In respect of state participation in the wrongs committed by other states, a general complicity rule supplements existing specific rules. In respect of state participation in harms caused by non-state actors, the obligations now imposed by international law on non-state actors have opened up the possibility of accounting for that participation as a form of complicity. Even if Ago was correct in 1939, it is not the case now that 'any form of complicity, participation, or incitement to a delict' is inconceivable in international law. 


\section{CHAPTER 7. STATE COMPLICITY IN THE INTERNATIONALLY WRONGFUL ACT OF ANOTHER STATE}

\subsection{INTRODUCTION}

States sometimes go to war alone. More often, they do so with the support of other states. $^{744}$ Given that international peace and security is at the heart of the Charter system, ${ }^{745}$ it is no surprise that one of the clearest manifestations of a prohibition on state complicity arises in respect of the wrong of aggression. Here, international law prohibits a specific form of state complicity in a specific wrongful act by the principal state.

There are other instances of state practice condemning state participation in other international wrongs. ${ }^{746}$ The International Law Commission relied on this practice to derive its claim that international law assigns 'international responsibility to a State which deliberately participates in the internationally wrongful conduct of another through the provision of aid or assistance... ${ }^{747}$ This is the rule reflected in Article 16 ARSIWA. Despite its shortcomings, Article 16 is a radical leap in the morality of international law. ${ }^{748}$

Article 16 represents a move from the specific to the general. It prohibits general forms of complicity_aid or assistance — in the commission of any international wrong by the recipient state, so long as the act committed by the

\footnotetext{
${ }^{744}$ See Georg Nolte and Helmut Aust, 'Equivocal Helpers - Complicit States, Mixed Messages and International Law' (2009) 58 ICLQ 1.

${ }^{745}$ Art 1(1) UN Charter; Declaration on Friendly Relations.

${ }^{746}$ For an overview of state practice and opinio juris in respect of other potential state complicity rules, see generally Aust, Complicity in the Law of State Responsibility 97-191; Quigley, 'Complicity in International Law' 81-107.

${ }^{747}$ ARSIWA Commentary on Art 16 [7].

${ }^{748}$ Lowe, 'Responsibility for the Conduct of Other States' 12.
} 
principal state would be wrongful if committed by the accomplice state. ${ }^{749}$ That international law is moving from specific rules to a general rule in the context of complicity is no surprise. In fact, it mirrors the historical evolution of complicity rules in the municipal criminal context. Vogel explains that:

In modern criminal codes, [rules on participation] are laid down in the general part, they apply - in principle - to any specific offence and are spelt out in an abstract, general and not casuistic way which may be called the 'general part' model. In contrast, a 'special part' model provides for specific participation rules in specific offences.

Historically speaking, the law on participation in the offence started from specific and casuistic rules in the special part-e.g. as annex to the murder prohibition in ancient criminal law - and developed into the abstract, general rules in the general part which are now the international standard. ${ }^{750}$

The rule reflected in Article 16 should be understood to entrench a general complicity rule in the law of state responsibility, at least with respect to state participation in wrongdoing committed by other states. This Chapter places the specific rule prohibiting complicity in aggression and the general rule reflected in Article 16 within the analytical framework proposed in Chapter 2 and evaluates them against the normative claim of the thesis.

\subsection{State Complicity in Aggression - A Specific Complicity Rule}

\subsubsection{Introduction}

The prohibition of aggression outlaws the use by states of armed force against the sovereignty, territorial integrity, or political independence of other states. ${ }^{751}$ The rule pursues the principal aim of the Charter system - the maintenance of international peace and security — and thereby reflects a fundamental value of the international

\footnotetext{
${ }^{749}$ Art 16 ARSIWA.

${ }^{750}$ Vogel, 'Twelve Models' 160.

${ }^{751}$ Art 1 Definition of Aggression.
} 
legal system. ${ }^{752}$ In perpetrating acts of aggression, states often act with the assistance of other states. In practice, such assistance takes a variety of forms. There is not, however, a general rule prohibiting complicity in aggression, the content of which is fleshed out from first principles to cover these various forms of assistance. Rather, practice establishes the prohibition of a specific kind of complicity: the placing of territory at the disposal of an aggressor state. There are, however, some indications of the existence of a wider rule in this context.

\subsubsection{Placing Territory at the Disposal of an Aggressor State}

\subsubsection{International Practice}

The essence of the prohibition on state complicity in aggression is found in the provision by one state of its territory to an aggressor state; that is, a state perpetrating an act of aggression against a third state. Article 3(f) of the Definition of Aggression, adopted by the General Assembly in Resolution 3314 of 1974 following the work of the Assembly's Special Committee on the Question of Defining Aggression, provides the textual basis of the rule:

Any of the following acts, regardless of a declaration of war, shall, subject to and in accordance with the provisions of article 2 , qualify as an act of aggression:

(f). The action of a State in allowing its territory, which it has placed at the disposal of another State, to be used by that other State for perpetrating an act of aggression against a third State. $^{753}$

\footnotetext{
${ }^{752}$ Art 1(1) UN Charter. See also Armed Activities [148].

${ }^{753}$ Art 3(f) Definition of Aggression.
} 
State practice confirms the existence of this specific rule, much of which is cited in the Commentary to ARSIWA as support for the rule reflected in Article $16 .{ }^{754}$ For example, in 1958 the Federal Republic of Germany was accused by the Union of Soviet Socialist Republics of being complicit in an armed attack by the United States on Lebanon. The basis of the allegation was that US aircraft had used German airfields during the intervention. The ILC explains that the FRG 'seems to have accepted that the act of a State in placing its own territory at the disposal of another State in order to facilitate the commission of an unlawful use of force by that other State was itself an internationally wrongful act. ${ }^{755}$ This interpretation of the FRG's position is accurate and is demonstrated by the following note sent by the FRG to the USSR:

There can be no doubt that the allies of the German Federal Republic were not guilty of any aggression in the Near and Middle East ... The Government of the German Federal Republic has never approved nor favored an act of aggression. Neither has it ever placed the territory of the Federal Republic at the disposal of another for such an act. ${ }^{756}$

Quigley explains that similar protests from the USSR followed in 1958 in respect of Italy's granting of air and sea rights to the US in the course of its intervention in Lebanon, and Israel's granting the UK and US permission to fly over its territory in the course of Britain's intervention in Jordan. ${ }^{757}$ Guinea and Mali charged the United Kingdom with complicity in aggression for allowing Ascension Island to be used by Belgian and US forces for intervention in the Democratic

\footnotetext{
${ }^{754}$ ARSIWA Commentary on Art 16.

${ }^{755}$ Ibid [8].

${ }^{756}$ H. Alexy, 'Völkerrechtliche Praxis der Bundesrepublik Deutschland im Jahre 1958' Zeitschrift für ausländisches öffentliches Recht und Völkerrecht, 20 (1959-60) 636, 663-4 quoted in Quigley, 'Complicity in International Law' 83.

${ }^{757}$ Quigley, 'Complicity in International Law' 83-84.
} 
Republic of the Congo. ${ }^{758}$ In addition, it appears that the United Kingdom itself accepts that such a prohibition exists. Following an attack by Egypt on a village in Saudi Arabia in 1965, Britain protested not only Egypt's aggression but also Yemen's alleged complicity in the attack. ${ }^{759}$

The attacks on Libyan targets carried out by the United States on 14 and 15 April, 1986, provide a range of state practice in support of the specific rule. France and Spain denied the US over-flight rights on the basis of concerns over the operation's legality. ${ }^{760}$ The United Kingdom agreed to a request by the US for use of its air bases. ${ }^{761}$ In response to this support, both the Libyan Arab Jamahiriya ${ }^{762}$ and the United Arab Emirates (as a member of the Security Council at the time) condemned the UK's involvement in the attacks. The UAE made the following statement:

We hold the United States - a permanent member of the Councilresponsible for that act of aggression and for its consequences; we also hold the United Kingdom responsible, since it authorized the use of bases on its territory for the purpose of launching a military act of aggression against Libya. ${ }^{763}$

In response to these accusations, the United Kingdom defended the attack by the US as lawful rather than deny that responsibility arises in law for conduct of this kind. ${ }^{764}$ A proposed Security Council resolution was vetoed but the General

\footnotetext{
${ }^{758}$ UN Doc S/PV.1171 [8], [53]. See Aust, Complicity in the Law of State Responsibility 110-111.

${ }^{759}$ Quigley, 'Complicity in International Law' 84.

${ }^{760}$ See Chinkin, Third Parties in International Law 296.

${ }^{761}$ Statement of Prime Minister Thatcher HC Deb 15 April 1986 vol 95, cols 729-39.

${ }^{762}$ UN Doc S/PV.2674 p.11-12.

${ }^{763}$ UN Doc S/PV.2674 p.6.

${ }^{764}$ HC Deb 15 April 1986 vol 95, cols 729-39. See Aust, Complicity in the Law of State Responsibility 112.
} 
Assembly called on all states 'to refrain from extending any assistance or facilities for perpetrating acts of aggression against the Libyan Arab Jamahiriya. ${ }^{765}$

The Iraq war of 2003 provides a rich array of state practice concerning the provision of territory to an aggressor state from which it is difficult to draw any strong conclusions. $^{766}$ Some states, notably Switzerland, Turkey, and Norway, refused to permit the use of their airspace, though Aust argues that considerations other than a legal concept of complicity may have informed their positions. ${ }^{767}$ The conduct of other states, including Germany, was ambiguous, ${ }^{768}$ and, as is often the case, can best be explained by reference to the interplay between legal judgment and political need. $^{769}$

Although drawn from international criminal law, some support for the prohibition on complicity in aggression may also be inferred from the text of the definition of aggression adopted by consensus at the Kampala Review Conference of the Rome Statute of the International Criminal Court. The crime of aggression is defined as the 'planning, preparation, initiation or execution ... of an act of aggression $\ldots{ }^{770}$ It includes within the definition of an 'act of aggression' the conduct specified in Article 3(f) of the General Assembly's 1974 Definition of Aggression. ${ }^{771}$ The inclusion of Article 3(f) within the statute of the International Criminal Court may be

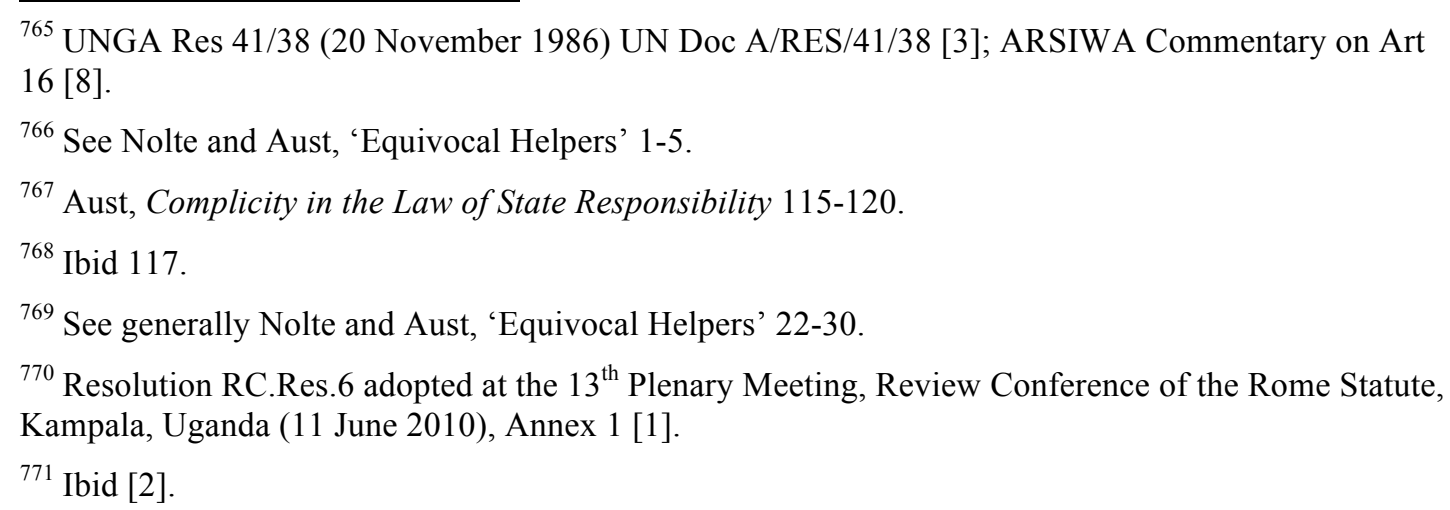


read as further confirmation of the existence of the rule. The prohibition on placing territory at the disposal of an aggressor state — a specific complicity rule—is entrenched in customary international law.

\subsubsection{The Content of the Rule}

Chapter 2 of this thesis proposed an analytical framework in which complicity rules may be assessed and defended a normative claim as to their optimal structure. This section uses that framework and claim to evaluate the obligation imposed on states by international law not to allow their territory to be used for an act of aggression.

Before doing so, it is worth pausing on a simple, yet fundamental, point.

Responsibility arises for the complicit state only where the principal state actually perpetrates an act of aggression against a third state —-without the principal's wrongful act, there is nothing for the complicit state to be complicit in. ${ }^{772}$ This follows from the essential derivative nature of complicity. ${ }^{773}$ For this reason, any defence available to the putative aggressor state absolves the complicit state of responsibility for complicity. In the case of the US bombing of Libya in 1986, the United Kingdom argued that the US's actions, and thus its provision of air bases to the US, was justified by the law of self-defence. ${ }^{774}$ The wrongfulness of the UK's participation turned on the wrongfulness of the US's actions.

The three elements of the analytical framework concern the forms of complicity prohibited, the nexus between the accomplice's acts and the principal's

\footnotetext{
${ }^{772}$ Quigley, 'Complicity in International Law' 86.

${ }^{773}$ Kadish, 'Complicity, Cause and Blame' 337.

${ }^{774}$ HC Deb 15 April 1986 vol 95, cols 729-39. See also ARSIWA Commentary on Art 16 [8]; Christopher Greenwood, 'International Law and the United States' Air Operation against Libya' (1986/1987) 89 W. Va L. Rev. 933.
} 
wrong, and the fault of the accomplice. Starting with the forms of complicity prohibited, the first thing to note is the narrowness of the prohibition on complicity in aggression-allowing another state to use its territory for perpetrating an act of aggression. In contrast to the generality of the doctrines of instigation and aiding and abetting in international criminal law, the customary prohibition on state complicity in aggression prohibits a very specific form of assistance. Its specificity should not be taken to signify a lack of importance; indeed, the inclusion of Article 3(f) within the Definition of Aggression indicates a targeted concern at a particularly culpable way in which states help other states to commit aggression.

A second point to note is the curious formulation of Article 3(f) - ' $[\mathrm{t}]$ he action of a State in allowing its territory, which it has placed at the disposal of another State... ${ }^{775}$ This may be read to suggest that positive action on the part of the complicit state is required, possibly excluding liability for complicit omissions. In some cases, the complicit state will be heavily involved in the military operation, providing logistical support for troop movements on its territory, or perhaps air-traffic control for aerial attacks. In other cases, the complicit state's involvement will be minor. Too much should not be made of this conduct element. It requires only that the complicit state allow its territory to be used by the aggressor state. A simple grant of permission will suffice.

Within this second point is the concept of territory. In the absence of practice to the contrary, territory in the prohibition on complicity in aggression should be defined under ordinary principles of international law. The concept of territory

\footnotetext{
${ }^{775}$ Definition of Aggression (emphasis added).
} 
includes a state's land, airspace, and territorial sea. ${ }^{776}$ It would also extend to occupied territory. Beyond these obvious and core instances, this issue may arise in more complicated situations such as vassalage, suzerainty, and lease. The most sensible standard to adopt in these situations is one of effective exercise of jurisdiction by the state over the disputed territory. Brownlie explains that this has been the approach of national courts when interpreting the term territory in various international agreements and treaties. ${ }^{777}$ If a state exercises jurisdiction over territory, it is not unreasonable to prohibit it from placing that territory at the disposal of an aggressor state.

The second element of the analytical framework concerns the nexus between the accomplice's acts and principal's wrong. As argued in Chapter 2, accomplices are best viewed as making an indirect causal contribution to the harm caused by the principal. ${ }^{778}$ We do not need to ask if the act would have occurred in any case - that the actor's assistance was not a sine qua non does not mean that she did not make a contribution. In assessing that contribution, however, Chapter 2 also argued for a nexus requirement that excludes de minimis contributions - a standard of substantial contribution was suggested as a general rule. ${ }^{779}$

What that means in the context of complicity in aggression is not easy to determine. The appropriateness of a substantiality standard in the criminal law is underpinned by an appreciation of the generality and breadth of criminal prohibitions

\footnotetext{
${ }^{776}$ See Ian Brownlie, Principles of Public International Law ( $7^{\text {th }}$ ed., OUP 2008) 105; Antonio Cassese, International Law (2 ${ }^{\text {nd }}$ ed. OUP 2005) 81.

${ }^{777}$ Brownlie, Principles of Public International Law 112.

${ }^{778}$ See Ch. 2.5.3 above; Smith, A Treatise on Complicity 89; Gardner, 'Complicity and Causality' 128.

${ }^{779}$ See Ch. 2.5.3 above.
} 
of complicity. Usually, the doctrine encompasses (i) any form of complicity (ii) in any crime. The current rule concerns a specific (and serious) kind of complicity- the placing of territory at the disposal of the aggressor state - in a specific (and serious) wrong-aggression. For this reason, it makes sense to argue that the placing of territory at the disposal of an aggressor state always fulfills the nexus requirement, no matter where the territorial state lies in relation to the site of conflict.

The third element of the framework concerns the culpability of the complicit actor. In this regard, responsibility of the complicit state will not arise where it did not know about the use of its territory by the aggressor state. This flows from the language of the rule reflected in Article 3(f). If an aggressor state were to launch an aggressive act from the territory of another state without that state's knowledge, it could not be said that the state had 'placed' its territory at the disposal of the aggressor state for perpetrating an act of aggression. In such a case, no responsibility would arise under this rule. ${ }^{780}$

These are the three elements of the rule. The relationship between the conduct and fault elements raises a difficult question. Would responsibility for complicity in aggression arise where a state, without explicitly placing its territory at the disposal of the aggressor state, acquiesces in that state of affairs? Putting that another way, if State A knows that State B is flying over its territory en route to an act of aggression against State $\mathrm{C}$ but does nothing to protest the action, is State A responsible to State C? One argument is that in the absence of state practice to the contrary, responsibility

\footnotetext{
${ }^{780}$ This is not to say that in such a case responsibility would not arise for a breach of the duty to ensure that one's territory is not used for acts contrary to the interests of another state, a duty conditioned by a due diligence obligation.
} 
should be confined to situations where there is a positive act of consent by the complicit state, as may be suggested by the text. Concern that states would acquiesce in acts of aggression launched from their territory may be mitigated by adopting a broad view of what constitutes positive action. A broad view of the action requirement could include any action by a state prior to, or during, the aggressive act suggesting consent or approval. This might include an indication short of explicit consent that the state would not protest the use of its territory.

The better interpretation is that the rule reflected in Article 3(f) encompasses the possibility of complicity by omission. As argued in Chapter 2, particularly culpable omissions should give rise to responsibility for complicity. As noted above, states are undoubtedly bound by a general obligation, conditioned by a requirement of due diligence, 'to protect within [their] territory the right of other States. ${ }^{781}$ This broader obligation will be breached in many more instances than will constitute a complicit omission, including instances where a state acquiesces in the unlawful use of its territory by another state. Moreover, the broader due diligence obligation is an example of direct responsibility, and does not operate so as to link the state to the subsequent wrongful act of the other state. ${ }^{782}$ However, in respect of particularly culpable omissions, specifically those where the accomplice state had knowledge of the wrongful act and failed to act in breach of such a specific obligation, the omission should be seen as a form of complicity. In the present case, a state that acquiesces in the use of its territory for an act of aggression should be responsible for complicity in aggression. $^{783}$

\footnotetext{
${ }^{781}$ Island of Palmas 839.

${ }^{782}$ See Fletcher, Rethinking Criminal Law 423

${ }^{783}$ For further discussion of complicit omissions and state responsibility, see Ch. 7.3.5.1 below.
} 


\subsubsection{The Structure of the Rule}

Chapter 2 set out the normative claim of the thesis. Complicity is a particular mode of wrongdoing. In reflecting complicity as a particular mode of wrongdoing, the law should hold accomplices responsible for, and label them in terms of, their own contribution to the principal's wrong rather than for the wrong of their principal. When we are dealing with individual responsibility, the principle of culpability sustains this claim. When we are dealing with state responsibility, this claim is underpinned by the fundamental value of sovereignty. ${ }^{784}$

The customary rule reflected in Article 3(f) prohibits a specific kind of complicity in a specific wrong - allowing one's territory to be used for an aggressive act. The formulation of the rule is interesting: it provides that complicity of this kind itself 'qualif[ies] as an act of aggression. ${ }^{785}$ On the face of it, the complicit state is not perpetrating some discrete wrong of facilitating or assisting aggression, but rather aggression itself. This point was made by Germany in its comments on a previous draft of ARSIWA:

[T] he action of a State allowing its territory to be used by another State for perpetrating an act of aggression as described in article 3(f) of the Definition of Aggression qualifies as an act of aggression and not as aiding aggression. ${ }^{786}$

Here, care should be taken. The formulation of Article 3(f) might be interpreted as an imputational complicity rule. This is not the case. Although the act

\footnotetext{
${ }^{784}$ See Nollkaemper and Jacobs, 'Shared Responsibility in International Law' 386.

${ }^{785}$ Art 3(f) Definition of Aggression.

${ }^{786}$ International Law Commission, 'State Responsibility - Comments and Observations Received from Governments’ (1998) UN Doc. A/CN.4/488, Germany, 76.
} 
of assistance is itself an act of aggression, the complicit state is not responsible for the acts of the aggressor state; that is, it is not responsible for the aggressor state's acts of aggression. The responsibility of the complicit state is derivative in one sense-it arises only where the primary acting state actually commits aggression ${ }^{787}$ — but it is not derivative and imputational. The acts of the aggressor state are not imputed to the complicit state.

Thus on first glance, the central problem of a common law conception of complicity is avoided. As illustrated in Chapter 2, the common-law model of complicity imputes to the accomplice the wrong of the principal. This is not the case in this instance - the law holds the complicit state responsible for its own acts. However, imposing the label of aggression on a state that allows another state to commit aggression from its territory is something of a fiction. ${ }^{788}$ The logic of complicity is to render an otherwise lawful act wrongful when it assists in the perpetration of a wrong by another actor. In this instance, the principal wrong is the act of aggression by the principal state. The wrongfulness of the complicit state's conduct lies in its facilitation of that act of aggression.

For this reason, the rule reflected in Article 3(f) of the Definition of Aggression may be subject to criticism in terms of the principle of fair labelling. The fact that the assisting state is not actually held responsible for the principal state's acts is important, and goes some way to immunising the rule from critique. However, the accomplice state's indirect causal contribution—its complicity—is not properly

\footnotetext{
${ }^{787}$ Quigley, 'Complicity in International Law' 86.

${ }^{788}$ See Ch. 2.4.2 above. For an example of this approach in domestic criminal law, see W. Va. Code $\S$ 61-3-1 (1977) cited in Robinson 'Imputed Criminal Liability' n.6.
} 
described. A better description would be complicity in aggression, or, more precisely, facilitating an act of aggression.

\subsubsection{Beyond Territorial Complicity}

The rule prohibiting the placing of territory at the disposal of an aggressor state addresses a narrow and specific form of complicity. There is also state practice denoting a wider rule in respect of both aggression and the prohibition on the use of force. The strongest evidence may be found in the provision of military aid that is used to commit aggression, though some practice is more general both at the level of aid provided and in respect of the wrong assisted. ${ }^{789}$ As a general principle, the provision of aid, military or otherwise, is lawful in international law, setting a baseline presumption allowing free intercourse among nations. ${ }^{790}$ This base-line is circumscribed by allegations of complicity.

Some examples may illustrate the point. In 1951, the General Assembly condemned the People's Republic of China's participation in North Korea's acts of aggression during the Korean Crisis, stating that: '[T]he Central People's Government of the People's Republic of China, by giving direct aid and assistance to those who were already engaged in committing aggression... has itself engaged in aggression in

\footnotetext{
${ }^{789}$ See Quigley, 'Complicity in International Law' 87-95; Aust, Complicity in the Law of State Responsibility 129-145; Ago, 'Seventh Report on State Responsibility’ [71].

${ }^{790}$ See the response of the United Kingdom Secretary of State for the Colonies to inquiries regarding the use of arms by Yemeni forces against the Crown colony of Aden in 1958, arms supplied to Yemen by a third state-House of Commons Debates, Vol. 589, col. 891, (17 June 1958) reprinted in Elihu Lauterpacht, 'The Contemporary Practice of the United Kingdom in the Field of International Law Survey and Comment' (1958) 7 ICLQ 514, 551. See also Lowe, 'Responsibility for the Conduct of Other States' 6, discussing the requirement of knowledge for state responsibility to arise: 'There is, for example, nothing wrong, in principle, with supplying vehicles to another State.'
} 
Korea. ${ }^{791}$ The ILC, again citing practice in support of the general rule in Article 16 ARSIWA, notes that the Islamic Republic of Iran protested the UK's supply of aid to Iraq in the Iran-Iraq war, aid which allegedly facilitated Iraq's aggression. ${ }^{792}$ This allegation was denied by the UK. In 1982, after declaring that Israel's occupation of the Golan Heights constituted an act of aggression, the General Assembly called on member states to refrain from supplying aid or assistance to Israel. ${ }^{793}$ The relevant part of the resolution passed by 87 votes to 22 , with 31 abstentions.

A broad notion of complicity may also be seen in national and supranational statements and policies that limit the sale of arms. ${ }^{794}$ In 1950, Britain, France, and the United States issued a short statement concerning the maintenance of peace and stability in the Middle East. After recognising that both Israel and the Arab states 'need to maintain a certain level of armed forces for the purposes of assuring their internal security and their legitimate self-defense,' the declaration states that:

The three Governments declare that assurances have been received from all the states in question, to which they permit arms to be supplied from their countries, that the purchasing state does not intend to undertake any act of aggression against any other state. Similar assurances will be requested from any other state in the area to which they permit arms to be supplied in the future. ${ }^{795}$

In a comprehensive survey, Aust details a range of international practice, including domestic legislation on arms exports, concerning the provision of military

\footnotetext{
${ }^{791}$ UNGA Res 498 (V) (1 February 1951) UN Doc A/RES/498 [1]. See Aust, Complicity in the Law of State Responsibility 109.

792 ARSIWA Commentary on Art 16 [7].

${ }^{793}$ UNGA Res 37/123 (16 December 1982) UN Doc A/RES/37/123 [13]. See also UNGA Res 36/27 (13 November 1981) UN Doc A/RES/36/27 in respect of Israel's destruction of the Osirak reactor in Iraq.

${ }^{794}$ See Aust, Complicity in the Law of State Responsibility 129.

795 Tripartite Declaration of France, Britain and the United States 25 May 1950.
} 
support to states suspected of violating international law. ${ }^{796}$ More recently, ideas of complicity can be seen in the statements of Azerbaijan regarding Russia's support for what Azerbaijan characterises as Armenia's aggression during the Nagorno-Karabakh war of 1992-1994. ${ }^{797}$ Following the break-up of the Soviet Union, and spurred by tensions between ethnic Armenians and Azeris within Nagorno-Karabakh, Armenian forces occupied parts of Azerbaijan. In a statement to the United Nations Economic and Social Council, Azerbaijan’s Permanent Representative condemned Russia’s supply of large quantities of weapons to Armenia, stating that 'the arms supplies have substantially enhanced the fighting capacity of the Armenian forces, which have carried out warlike actions and occupied Azerbaijani territory.' Continuing, the letter describes such arms transfers to a belligerent as 'violat[ing] the principles and standards of international law... ${ }^{, 798}$

This practice raises particular interpretive difficulties because it is not entirely clear that the illegality articulated by Azerbaijan relates specifically to a rule of complicity in aggression. ${ }^{799}$ It may refer to obligations relating to an ongoing occupation, or to the supply of weapons used to violate human rights norms, or indeed to the general rule of aid or assistance in the commission of an international wrong.

\footnotetext{
${ }^{796}$ See Aust, Complicity in the Law of State Responsibility 129-145.

${ }^{797}$ The Security Council issued four resolutions regarding the conflict in 1993: UNSC Res 822 (30 April 1993) UN Doc S/RES/822; UNSC Res 853 (29 July 1993) UN Doc S/RES/853; UNSC Res 874 (14 October 1993) UN Doc S/RES/874; UNSC Res 884 (12 November 1993) UN Doc S/RES/884.

${ }^{798}$ Letter dated 21 July 1998 from the Permanent Representative of the Republic of Azerbaijan to the United Nations Office at Geneva, addressed to the secretariat of the Sub-Commission on Prevention of Discrimination and Protection of Minorities, Economic and Social Council, E/CN.4/Sub.2/1998/31 (22 July 1998).

${ }^{799}$ For a discussion of difficulties along these lines see Aust, Complicity in the Law of State Responsibility 103-107.
} 
These interpretive difficulties are not confined to assessments of Azerbaijan's practice in the present case. At best, it seems arguable that international law imposes a specific obligation on states prohibiting the knowing provision of military aid to an aggressor state. Lauterpacht, writing in 1958, suggests that a state may not escape responsibility for complicity in aggression where it 'knowingly supplies arms to another [state]. ${ }^{800}$ Quigley to some extent founds his assertion of a general rule of complicity in public international law on practice and opinio juris arising in the context of material aid to an aggressor state. ${ }^{801}$ And Graefrath, criticising the broad approach to complicity taken in Article 27, now Article 16, of an earlier draft of ARSIWA, describes 'the supply of weapons to support a State which commits aggression' as one of the typical examples of primary rules of complicity. ${ }^{802}$ This rule may be seen as an interstate analogue of the prohibition on the supply by states of arms to non-state actors engaged in acts of civil strife in another state. ${ }^{803}$

\subsubsection{Conclusion}

Where states seek to use force against non-neighboring states, the territory of other states is often implicated. To serve the value of international peace, international law prohibits states from placing their territory at the disposal of an aggressor state. Such complicit conduct will constitute an independent act of aggression by the aiding state. It is also likely that states will invoke the language of complicity to condemn the provision of weapons to aggressor states. These rules are constrained by their specificity, especially when contrasted with the wide construction of complicity in

\footnotetext{
${ }^{800}$ Lauterpacht, 'The Contemporary Practice of the United Kingdom - 1958' 551.

${ }^{801}$ Quigley, 'Complicity in International Law' 87-90.

${ }^{802}$ Bernhard Graefrath, 'Complicity in the Law of International Responsibility' (1996) Rev. Belge de Droit Intl 371, 373.

${ }^{803}$ Art 1 Declaration on Friendly Relations. See Nicaragua [228]; Armed Activities [162].
} 
international criminal law. Nonetheless, these rules are an important step in the development of international law's concern with complicity - first the move from a historical absence of complicity rules to a specific and piecemeal approach, and then, as will be seen in Chapter 7.3 below, the move from a specific and piecemeal approach towards a general and principled approach.

\subsection{A General Complicity Rule - Article 16 ARSiWA}

\subsubsection{Introduction}

The prohibition on state complicity in aggression is a specific complicity rule-it emerged to prohibit a specific form of participation in a specific international wrong. International law now recognises a general prohibition on state complicity. After nearly fifty years of work, the International Law Commission's Draft Articles on Responsibility of States for Internationally Wrongful Acts were adopted at the ILC's fifty-third session in 2001, submitted to the General Assembly, and commended by that body to governments in Resolution 56/83. ${ }^{804}$ Much ink has been spilled over certain aspects of the Articles, notably concerning the ultimately abandoned notion of state crimes. ${ }^{805}$ Chapter IV ARSIWA, which concerns the responsibility of states in connection with the actions of another state, includes Article 16. Article 16 sets out a rule that prohibits states from aiding or assisting another state in the commission of an internationally wrongful act. ${ }^{806}$

\footnotetext{
${ }^{804}$ UNGA Res 56/83 [3].

${ }^{805}$ See Joseph Weiler, Antonio Cassese and Marina Spinedi (eds), International Crimes of State: A Critical Analysis of the ILC's Draft Article 19 on State Responsibility (Walter de Gruyter 1989); Derek Bowett, 'Crimes of State and the 1996 Report of the International Law Commission on State Responsibility’ (1998) 9 Eur. J. Intl L. 163; Alain Pellet, 'Can a State Commit a Crime? Definitely, Yes!' (1999) 10 Eur. J. Intl L. 425; Nina Jørgensen, The Responsibility of States for International Crimes (OUP 2000).

${ }^{806}$ Art 16 ARSIWA.
} 
This section assesses the place of Article 16 within the conceptual structure of the ILC's Articles as a whole, considers the content of the rule within the analytical framework of this thesis, and evaluates the structure of the rule. Despite limitations, Article 16 is a great step forward in the way international law deals with state complicity. It reflects a move from the specific and piecemeal to the general and principled.

\subsubsection{The Basic Structure of the Articles on State Responsibility}

A distinction between primary and secondary rules underpins the Articles on State Responsibility. ${ }^{807}$ As is well known, Roberto Ago, the second special rapporteur on the project, provided this conceptual framework in his second report in $1970{ }^{808}$ His underlying idea was that the law of state responsibility consists of a coherent set of secondary rules that apply in the event of a breach of a primary rule — that is, a substantive obligation binding states. The Articles are a set of default rules and include those determining which acts are state acts, what consequences arise from the breach of an international obligation, and when the wrongfulness of an act may be precluded. ${ }^{809}$ Primary rules, then, are rules of international law that determine the scope of acceptable conduct of the subject to whom they are addressed. ${ }^{810}$ These were seen not to be a matter of state responsibility and thus not a matter for ARSIWA.

\footnotetext{
${ }^{807}$ See James Crawford, 'The ILC's Articles on Responsibility of States for Internationally Wrongful Acts: A Retrospect' (2002) 96 Am. J. Intl L. 874, 876 terming the distinction the Articles' 'central organizing device.'

${ }^{808}$ Roberto Ago, 'Second Report on State Responsibility - the Origin of International Responsibility' (1970) UN Doc A/CN.4/233 (1970) II YILC 177. This Report formalised the position taken by Ago as chairman of the sub-committee set up by the ILC in 1963 in proposing a new approach to the codification of the law of state responsibility after the difficulties experienced during the tenure of Special Rapporteur F.V. García-Amador. See Daniel Bodansky and John Crook, 'Symposium: The ILC's State Responsibility Articles - Introduction and Overview' (2002) 96 Am. J. Intl L. 773, 777-78.

${ }^{809}$ ARSIWA General Commentary [3].

${ }^{810}$ See Crawford, 'A Retrospect' 876-77.
} 
As Ago put it: '[I]t is one thing to define a rule and the content of the obligation it imposes, and another to determine whether that obligation has been violated and what should be the consequences of the violation., ${ }^{, 811}$

The Articles' foundational premise thus denies a concern with defining primary rules of conduct that create obligations for states. It is fair to say that Ago's decision to confine the project to secondary rules of responsibility contributed to state engagement during the drafting process and, in turn, to the eventual adoption of the Articles by the General Assembly. ${ }^{812}$ Nonetheless, the distinction is not without its critics, being termed elusive and unnecessary, ${ }^{813}$ and said to lead to a misunderstanding of the operation of the international legal system. ${ }^{814}$ These criticisms of the Articles' conceptual structure are not central to the assessment of Article 16; it is Article 16's position within that supposed structure that is of concern to this thesis.

\subsubsection{The Primary Nature of Article 16}

Article 16 sets out the following rule:

A State which aids or assists another State in the commission of an internationally wrongful act by the latter is internationally responsible for doing so if:

\footnotetext{
${ }^{811}$ Ago, 'Second Report on State Responsibility' 178. See also ARSIWA General Commentary [2]; Crawford, 'A Retrospect' 876.

${ }^{812}$ Crawford, 'A Retrospect' 877; Bodansky and Crook, 'Introduction and Overview' 780. See generally Alain Pellet, 'The ILC's Articles on State Responsibility for Internationally Wrongful Acts and Related Texts' in Crawford et al (eds), The Law of International Responsibility 75-94.

${ }^{813}$ Bodansky and Crook, 'Introduction and Overview' 780. See also Christian Tams, 'All's Well that Ends Well - Comments on the ILC's Articles on State Responsibility' (2002) Heidelberg J. Intl L. 759 , 764-765.

${ }^{814}$ Ulf Linderfalk, 'State Responsibility and the Primary-Secondary Rules Terminology - The Role of Language for an Understanding of the International Legal System’ (2009) 78 Nordic J. Intl L. 53, 72.
} 
(a) that State does so with knowledge of the circumstances of the internationally wrongful act; and

(b) the act would be internationally wrongful if committed by that State. ${ }^{815}$

In spite of its inclusion in ARSIWA, Article 16 embodies a primary rule of international law. ${ }^{816}$ That is to say, it is a rule that defines the scope of acceptable conduct for states. In fact, it may be thought of as a sort of primary meta-rule, in that it defines the bounds of acceptable state conduct in respect of all other primary rules. $^{817}$ This conclusion flows from ARSIWA's internal logic. Article 2 ARSIWA provides:

There is an internationally wrongful act of a State when conduct consisting of an action or omission:

(a) is attributable to the State under international law; and

(b) constitutes a breach of an international obligation of the State. $^{818}$

If we consider any matter between states in which Article 16 forms the basis of the claim, attribution — part (a) of the test—will be assessed in the ordinary manner. This may implicate one or more provisions in Chapter II of the Articles. Part (b), of course, will be founded on Article 16. In other words, Article 16 is the specified international obligation of the State. On this basis, Article 16 is clearly a primary rule. $^{819}$

\footnotetext{
${ }^{815}$ Art 16 ARSIWA.

${ }^{816}$ See Graefrath, 'Complicity in the Law of International Responsibility' 372; André Nollkaemper, 'Internationally Wrongful Acts in Domestic Courts' (2007) 101 Am. J. Intl L. 760, n100.

${ }^{817}$ See generally Lanovoy, 'Revisiting a Structural Norm' 1.

${ }^{818}$ Art 2 ARSIWA.

${ }^{819}$ See Nollkaemper and Jacobs, 'Shared Responsibility in International Law' 409.
} 
No doubt the drafters were aware of this incongruity. ${ }^{820}$ Indeed, a previous iteration of Article 16 was said by the member of the Commission from New Zealand to 'leap the barrier between secondary and primary rules. ${ }^{,} 821$

The drafters attempt to explain the incongruity in two ways. First, the Commentary notes that the Chapter in which Article 16 falls might be seen to blur the boundary between primary and secondary rules, but that its inclusion is nonetheless justified because responsibility 'is in a sense derivative. ${ }^{822}$ Taking this a step further, it likens the rules in Chapter IV to those in national legal systems dealing with conspiracy, complicity, and inducing breach of contract. Because rules of this kind may appear in the general part of the law of obligations, the inclusion of Articles 16, 17, and 18 ARSIWA is defensible. The final part of this justification is a non sequitur. It does not follow from the inclusion of complicity within the general part of the law of obligations that the ILC could prescribe rules that define the boundaries of substantive conduct for states without crossing into the sphere of primary rules.

The second way that the drafters justify the incongruity of Article 16 is, on closer analysis, an argument made more in mitigation than defence. More than once, the Commentary emphasises the exceptional nature of responsibility under Chapter IV. ${ }^{823}$ Then, in defining the applicable test, it underlines the limited scope of Article 16. The language used betrays unease with the rule's position within the conceptual

\footnotetext{
${ }^{820}$ ARSIWA General Commentary on Chapter IV [7]: 'A feature of this chapter is that it specifies certain conduct as internationally wrongful.' See also Graefrath, 'Complicity in the Law of International Responsibility' 372.

${ }^{821}$ (1978) I YILC 1, 236.

${ }^{822}$ ARSIWA General Commentary on Chapter IV [7].

${ }^{823}$ Ibid [5], [8].
} 
framework of the Articles as a whole: 'Article 16 limits the scope of responsibility for aid or assistance in three ways. ${ }^{, 824}$ This is not quite correct. Rather, Article 16 imposes responsibility for aid and assistance — substantive conduct — and limits the scope of the primary obligation thereby imposed in three ways. The emphasis on its limited nature is an affirmation of the Article's incongruity. It confirms the view that Article 16 is a primary rule of international law.

\subsubsection{The Legal Status of Article 16}

Despite doubts prior to its adoption, it is clear that Article 16 reflects a rule of customary international law. During the drafting process, state responses to Article 16 and its prior iterations were mixed. Commenting on the draft articles adopted by the Commission in its $48^{\text {th }}$ session, Switzerland argued that Article 27, as it was then, had no basis in positive law, and Germany that its foundation in international law and practice was doubtful. ${ }^{825}$ The United Kingdom supported the basic principle. ${ }^{826}$ At other stages of the process, responses were likewise mixed, though more states favoured Article 16's inclusion than opposed it. ${ }^{827}$

One preliminary question is whether this incongruity in the nature of Article 16 will affect its reception as a rule of international law in comparison to the other Articles. It is doubtful that this would be so. At this point, it is sufficient to note that

\footnotetext{
${ }^{824}$ ARSIWA Commentary on Article 16 [3].

${ }^{825}$ International Law Commission, 'State Responsibility - Comments and Observations Received from Governments' (1998) 75-76.

${ }^{826}$ Ibid 76.

${ }^{827}$ Nolte \& Aust, 'Equivocal Helpers' 8. In support see e.g. International Law Commission, 'Observations and Comments from Governments on Chapters I, II, and III of Part I of the Draft Articles on State Responsibility for Internationally Wrongful Acts' (1980) UN Doc A/CN.4/328, Mali, 101; International Law Commission, 'State Responsibility - Comments and Observations Received from Governments’ (1999) UN Doc A/CN.4/492, Japan, 11.
} 
the ILC was established by the General Assembly to promote the progressive development of international law and its codification, and that there is nothing within the Commission's broader mandate denying it the ability to define and prescribe primary rules of international law. ${ }^{828}$ Indeed, the promotion of substantive rules of conduct has always formed part of its work. ${ }^{829}$ In the long term, it is likely that states and international institutions will approach the rule in Article 16 in a manner akin to any other Article.

Indeed, it is now established that the rule in Article 16 is one of customary international law. Considering Serbia's potential complicity in the genocide at Srebrenica under Article III(e) of the Genocide Convention, the ICJ declared that Article 16 reflects a rule of customary international law. ${ }^{830}$ In 2003, the Federal Constitutional Court of Germany considered a matter involving the luring by trickery of a Yemeni national to Germany carried out by an agent of the United States. The Yemeni national was then subject to an extradition request by the US. The Court held that if a rule of international law existed prohibiting the luring of a national to another state by trickery such that the United States' responsibility was established vis-à-vis Yemen, it may follow that Germany would be responsible to Yemen for assistance under the rule in Article 16. ${ }^{831}$ The Court also held that Article 16 codifies customary international law. ${ }^{832}$

\footnotetext{
${ }^{828}$ UNGA Res 174 (II) (21 November 1947).

${ }^{829}$ See e.g. International Law Commission 'Draft Code of Offences against the Peace and Security of Mankind' text adopted at its $48^{\text {th }}$ session (1996) II(2) YILC 30.

${ }^{830}$ Bosnian Genocide [420].

${ }^{831}$ Al-M (5 November 2003) 2 BVerfG 1506/03.

${ }^{832}$ Ibid [47]. See Nollkaemper, 'Internationally Wrongful Acts in Domestic Courts' 780. The complaint was dismissed on the basis that no rule of international law established the responsibility of the United States vis-à-vis Yemen for the trickery. There was no wrong for Germany to be complicit in.
} 
In addition, Article 16 has played an increasingly prominent role in international and national responses to state participation in the war on terror. ${ }^{833} \mathrm{In}$ 2009, the report of the Special Rapporteur on human rights and terrorism reiterated the applicability of Article 16 in the context of rendition, detention, and interrogation, ${ }^{834}$ as did an earlier report by the Venice Commission adopted at its plenary session in $2006 .{ }^{835}$ A good example of how the rule has influenced domestic practice is the report of the UK Parliament's Joint Committee on Human Rights into allegations of UK complicity in torture. Drawing on Article 16 and the Convention against Torture, the Committee adopted the following definition of state complicity in torture:

[F]or the purposes of State responsibility for complicity in torture ... complicity means simply one State giving assistance to another State in the commission of torture, or acquiescing in such torture, in the knowledge, including constructive knowledge, of the circumstances of the torture which is or has been taking place. ${ }^{836}$

The acceptance of Article 16 as a rule of customary international law might be evidence of what David Caron terms the paradoxical relationship between the form of the Articles and their authority. ${ }^{837}$ The paradox is that in their present form the ILC's Articles may come to have a greater influence on international law than would have

\footnotetext{
${ }^{833}$ See Aust, Complicity in the Law of State Responsibility 120-127.

${ }^{834}$ UNHRC, 'Report of the Special Rapporteur on the Promotion and Protection of Human Rights and Fundamental Freedoms while Countering Terrorism' (4 February 2009) UN Doc A/HRC10/3 [53].

${ }^{835}$ European Commission for Democracy through Law, 'Opinion on the International Legal Obligations of Council of Europe Member States in Respect of Secret Detention Facilities and InterState Transport of Prisoners' adopted by the Venice Commission at its $66^{\text {th }}$ Plenary Session (17 March 2005), Op. No. 363/2005 [45]. See also UNHRC, 'Joint Study on Global Practices in relation to Secret Detention in the Context of Countering Terrorism' (19 February 2010) UN Doc. A/HRC/13/42 [41].

${ }^{836}$ Joint Committee on Human Rights, Allegations of UK Complicity in Torture (2008-09) HL Paper 152 HC 230 [35].

${ }^{837}$ David Caron, 'The ILC Articles on State Responsibility: The Paradoxical Relationship between Form and Authority' (2002) 96 Am. J. Intl L. 857.
} 
been the case if they had instead formed the basis of a multilateral treaty ${ }^{838}$ This criticism is particularly valid in respect of Article 16, where the evidence adduced by the Commission for its customary status was not entirely convincing. In the Commentary, the ILC refers to a number of specific primary rules prohibiting states from participating in the wrongs of other states - those in respect of aggression, human rights violations, and the evasion of Security Council sanctions - as evidence of a general rule prohibiting participation in the wrongful act of another state. The critical absence is an explanation of how the general rule is founded on these primary rules. ${ }^{839}$ Nonetheless, Article 16 has taken hold as a rule of customary international law, one that defines acceptable conduct for states in their participation in the wrongdoing of other states.

\subsubsection{Assessing the Rule with the Analytical Framework}

Chapter 2 of this thesis set out an analytical framework for understanding the elements of complicity rules. The framework structures the analysis around the forms of complicity prohibited, the nexus between the accomplice's act and the principal's wrong, and the fault required of the accomplice. It will be seen that the rule in Article 16 includes an additional element: the double obligation requirement.

\subsubsection{The Conduct Element}

The conduct element of complicity under Article 16 is broad. Article 16 prohibits states from giving aid or assistance that facilitates another state's commission of an internationally wrongful act. There is no inchoate responsibility under Article 16-

\footnotetext{
${ }^{838}$ See also Crawford, 'A Retrospect' 889.

${ }^{839}$ Nolte and Aust, 'Equivocal Helpers' 8. See also Tams, ‘All's Well that Ends Well' 794.
} 
the assisted state must in fact commit the wrongful act. ${ }^{840}$ The Commentary lists financing, the provision of an essential facility, the provision of means for the closing of an international waterway, facilitating the abduction of persons on foreign soil, and assisting in the destruction of property belonging to third state nationals as examples of actions that fulfill the conduct element of the test. ${ }^{841}$ These examples demonstrate its breadth.

In the light of this breadth, it is sometimes asked if Article 16 is contingent on the provision of a certain kind of aid. ${ }^{842}$ This question should not be confused with a separate but related question: what is the required relationship between the aid or assistance and the wrongful act of the assisted state $?^{843}$ This latter question might be thought of as the nexus issue; it is the key to the operation of Article 16. On the former question, all kinds of aid and assistance fall within the rule. Lowe argues that it may include technical or financial assistance, the non-application of mandatory sanctions, and even the provision by states of credit or investment guarantees that facilitate investments by their companies in other states. ${ }^{844}$ This is surely correct. There is no principled reason for limiting the kind of aid or assistance that might implicate Article 16. The Commentary does not do so. ${ }^{845}$

\footnotetext{
${ }^{840}$ ARSIWA Commentary on Art 16 [5].

${ }^{841}$ ARSIWA Commentary on Art 16 [1].

${ }^{842}$ See Lowe, 'Responsibility for the Conduct of Other States' 5.

${ }^{843}$ See e.g. Nolte and Aust, 'Equivocal Helpers' 10.

${ }^{844}$ Lowe, 'Responsibility for the Conduct of Other States' 5-6. See also Talmon 'A Plurality of Responsible Actors' 218: 'The ILC has made it clear that no particular kind of aid or assistance is necessary in order for this responsibility to arise.'

${ }^{845}$ ARSIWA Commentary on Art 16.
} 
There are two outstanding issues concerning the forms of complicity prohibited by the rule in Article 16. First, the Commentary on Article 16 focuses on the provision of assistance as the sole mode of complicity - the various ways that a state may help another state in its commission of an internationally wrongful act. ${ }^{846}$ Likewise, in its consideration of Article 16 in the Bosnian Genocide case, the ICJ refers specifically to the "provision of means to enable or facilitate the commission of the crime..., ${ }^{847}$

These statements reflect a long-standing assumption in international law that excludes classic forms of complicity based on influencing the principal—inducing, instigation, abetting — from state responsibility for complicity in the wrongs of other states. ${ }^{848}$ Ago traces this exclusion to the conclusions of the Board of Commissioners set up under the Convention of 4 July 1831 between France and the United States, and argues that ' $[\mathrm{t}]$ he decision of a sovereign State to adopt a certain course of conduct is certainly its own, even if it has received suggestions and advice from another state, which it was at liberty not to follow. ${ }^{849}$ This position is widely assumed to be correct. ${ }^{850}$ As a result, in the absence of a specific treaty regime, ${ }^{851}$ forms of

\footnotetext{
${ }^{846}$ See Kadish, 'Complicity, Cause and Blame' 342.

${ }^{847}$ Bosnian Genocide 419.

${ }^{848}$ See ARSIWA General Commentary on Chapter IV [9]; James Crawford, 'Second Report on State Responsibility' (1999) UN Doc A/CN.4/498/Add.1 (1999) II(1) YILC 3

${ }^{849}$ Ago, 'Seventh Report on State Responsibility' [62]-[63].

${ }^{850}$ Quigley, 'Complicity in International Law' 80; Nolte and Aust, 'Equivocal Helpers' 13; Christian Dominicé, 'Attribution of Conduct to Multiple States and the Implication of a State in the Act of Another State' in Crawford et al (eds), The Law of International Responsibility 281, 285.

${ }^{851}$ See e.g. the prohibition on direct and public incitement to commit genocide, an inchoate wrong, in Article III(c) of the Genocide Convention. See also Bosnian Genocide [167].
} 
complicity that are clearly established in international criminal law—such as instigation and abetting - probably do not apply to states. ${ }^{852}$

Even if this conclusion is correct as a matter of positive law, it is not clear that it should be so. As much as individuals influence other individuals to commit crimes by instigation or encouragement, states influence the decisions of other states. ${ }^{853}$ In its commentary on a previous draft of Article 16, the ILC partially based its rejection of 'incitement' on the idea that the 'motives of State conduct in international relations cannot be assimilated' to the psychological motives underpinning prohibitions on incitement for individuals in domestic law. ${ }^{854}$ But we do not need an assimilation of the motives of states and individuals to recognise that states $d o$ influence the decisions of other states to commit internationally wrongful acts. Of course, there might be evidentiary difficulties in proving such influence, and the other elements of the complicity rule would knock out both more marginal, and less culpable, forms of influence. But just as a state should not help another state to do what it cannot do itself, ${ }^{855}$ so a state should not instigate another state to breach an obligation by which it is also bound.

Moreover, Ago's argument that 'the decision of a sovereign State to adopt a certain course of conduct is certainly its own' is not inconsistent with the operation of doctrines of complicit influence. ${ }^{856}$ Complicity does not deny the responsibility of the principal; indeed, it affirms it. For this reason, the ILC is incorrect to suggest that

\footnotetext{
${ }^{852}$ See ARSIWA General Commentary on Chapter IV [9].

${ }^{853}$ Influence in this case means influence short of coercion under Art 18 ARSIWA.

${ }^{854}$ (1978) II(2) YILC 100 [6]. See also Nollkaemper, 'The Charles Taylor Judgment'.

${ }^{855}$ ARSIWA Commentary on Article 16 [6].

${ }^{856}$ Ago, 'Seventh Report on State Responsibility' [62]-[63].
} 
such a prohibition would entail the possibility of the principal state 'avoiding or even reducing its responsibility by alleging "incitement" by another state'. ${ }^{857}$ A principled approach to complicity under Article 16 would encompass the provision of complicit influence.

The second issue regarding the forms of complicity prohibited by Article 16 concerns omissions. This issue has less to do with the ILC and more to do with the ICJ's holding in the Bosnian Genocide case. In interpreting the primary rule prohibiting complicity in genocide, the Court held that ' ...complicity always requires that some positive action has been taken to furnish aid or assistance to the perpetrators... ${ }^{858}$ On one account, the exclusion of complicit omissions might be interpreted to apply to Article 16. This is not necessarily the case: Lanovoy points out that it is not clear that the Court envisaged its reasoning extending to Article $16 .{ }^{859}$

There is, however, heritage to the idea that the distinction between (i) 'participation' in the wrongful acts of another state, and (ii) the direct breach of a due diligence obligation to prevent the occurrence of harm is founded on the line between acts and omissions; indeed, this was Ago's position in his Seventh Report on State Responsibility. In this regard, it is worth setting out Ago's argument in detail:

[I]t should be remembered that a case of "participation" in the internationally wrongful act of another cannot be found in the fact, or rather the sole fact, that a state failed to take the preventive or repressive measures required of it with respect to actions committed in its territory by an organ of another State to the detriment of a third State. By such failure, the State in question breaches an international obligation incumbent on it, which is quite different from the obligation

\footnotetext{
${ }^{857} \mathrm{Cf}$ (1978) II(2) YILC 100 [6].

${ }^{858}$ Bosnian Genocide [432].

${ }^{859}$ Lanovoy, 'Revisiting a Structural Norm' 5.
} 
breached on its territory by the organ of the foreign State. The murder of a foreign Head of State by organs of State A on the territory of State $\mathrm{B}$, and the failure of State B in its duty to adopt the necessary measures to prevent such an act if possible ... are two different internationally wrongful acts, each the responsibility of a different State. There is, of course, an undeniable link between the two acts ... but this link is not sufficient to make one of the acts appear as participation in the other. This does not mean that in specific cases there may not also be participation - in the form of "assistance" or "complicity" - of the territorial State in the internationally wrongful act perpetrated on its soil by the foreign State. But there is an additional element, a separate breach besides the mere failure to prevent and punish. As the Commission has previously emphasized, that failure, as such, can certainly not be defined as a form of complicity. ${ }^{860}$

As argued in Chapter 2, there is no good reason to exclude omissions in the face of a specific duty from the ambit of responsibility for complicity. As a matter of basic usage, some omissions do assist in the commission of wrongdoing. Moreover, some omissions are sufficiently wrongful as to link the omitting party to the ensuing harm. ${ }^{861}$ In criminal law, the paradigm case of a cleaner intentionally failing to lock a bank so as to facilitate a robbery seems to exemplify the wrong of complicity. ${ }^{862}$ In respect of state complicity, the ILC itself cites Article 3(f) of the Definition of Aggression as an example of a primary complicity rule. ${ }^{863}$ States may allow their territory to be used by an aggressor state by omission — failing to object, for instance. $^{864}$

In a system of law that imposes broad due diligence obligations on states to prevent certain harms from occurring, one difficult question is how to draw out a set

\footnotetext{
${ }^{860}$ Ago, 'Seventh Report on State Responsibility' [57].

${ }^{861}$ Fletcher, Rethinking Criminal Law 611.

${ }^{862}$ Ashworth, Principles of Criminal Law 410-411. See Ch. 2.5.2.2 above.

${ }^{863}$ ARSIWA Commentary on Art 16 [8].

${ }^{864}$ See Ch. 7.2.2 above. See also Lanovoy, 'Revisiting a Structural Norm' 9; Nolte and Aust, 'Equivocal Helpers' n43.
} 
of omissions that are so culpable as to not only constitute a breach of that due diligence obligation but also give rise to responsibility for complicity. ${ }^{865}$ As argued previously, that distinction should not be drawn solely on the basis of an act/omission distinction. Instead, the other elements of a complicity rule will pull into the ambit of complicity particularly culpable omissions that contribute significantly to the commission of the harm and exclude those that do not. To pick up Ago's example, we might compare:

1. State B, hosting the head of state of State A, fails to exercise due diligence in screening guests attending the head of state's speech. The head of state is assassinated by agents of State $C$; and

2. State B, hosting the head of state of State A, receives specific warning that agents of State $\mathrm{C}$ are present at the speech and are about to assassinate the head of state. State B does nothing.

In the first instance, State B will likely have breached its obligation to exercise due diligence in preventing acts on its territory detrimental to the interest of other states. $^{866}$ In the second instance, in addition to any such direct responsibility for the omission, on certain conditions the state's failure should be seen to give rise to a derivative form of responsibility for participation in the principal wrong committed by State C. ${ }^{867}$ Assuming State B's omission materially facilitated, or substantially contributed to, the principal wrong and the state had specific knowledge about the proposed attack, its conduct constitutes a complicit omission. This is what complicity rules do - they link the accomplice to the wrong of the principal. Here, the omission is sufficiently culpable as to constitute a form of complicity. ${ }^{868}$

\footnotetext{
${ }^{865}$ See Lanovoy, 'Revisiting a Structural Norm' 9.

${ }^{866}$ See Ch. 6.2 above; Ago, 'Seventh Report on State Responsibility' [57].

${ }^{867}$ Lanovoy, 'Revisiting a Structural Norm' 10. See also Fletcher, Rethinking Criminal Law 422.

${ }^{868}$ Kadish, 'Act and Omission' 70.
} 


\subsubsection{The Nexus Element}

The second element of any complicity rule concerns the relationship between the aid or encouragement provided and the wrongful act committed. Given the range of actions or omissions that might fulfill the conduct element of complicity, it was argued in Chapter 2 that a substantiality criterion should apply. On first glance, this is the approach of the ILC in respect of Article 16. The Commentary specifies as follows:

There is no requirement that the aid or assistance should have been essential to the performance of the internationally wrongful act; it is sufficient if it contributed significantly to that act. ${ }^{869}$

This standard demands that the assistance materially facilitates that commission of the wrongful act. ${ }^{870}$ It excludes assistance that is indirectly or remotely related to that act. ${ }^{871}$ This much seems clear. However, in discussing the nature of responsibility under Article 16, the Commentary appears to assume that assistance that 'may have been only an incidental factor in the commission of the primary act' might fall within its scope. ${ }^{872}$ This clearly suggests a different standard from one of significant contribution or material facilitation.

The standard of material facilitation is to be preferred. For a start, it appears within the paragraphs of the Commentary that define the scope of the test. As a matter of textual interpretation, therefore, material facilitation seems to be the

\footnotetext{
${ }^{869}$ ARSIWA Commentary on Art 16 [5].

${ }^{870}$ Crawford, 'Second Report on State Responsibility' [180]. See also Lowe, 'Responsibility for the Conduct of Other States' 5.

${ }^{871}$ Nolte and Aust, 'Equivocal Helpers' 10.

${ }^{872}$ ARSIWA Commentary on Article 16 [10].
} 
standard preferred by the ILC. ${ }^{873}$ Secondly, as to an evaluation of the requisite standard, the potential breadth of the rule in Article 16 should be noted. As a primary rule of international law, Article 16 defines the acceptable bounds of state conduct in cooperating with other states. Given that no limitation is imposed on the kinds of aid included within the first limb of the test, it serves the interests of international cooperation to require a nexus beyond incidental contribution to give rise to international responsibility. ${ }^{874}$ Put simply, incidental contribution sweeps too widely. Material facilitation is a standard that catches conduct with a sufficient causal link to another state's wrongdoing while excluding the incidental relationships that arise from virtually every state interaction.

\subsubsection{Fault element}

The standard of fault required by Article 16 was a controversial issue during the drafting process. ${ }^{875}$ Strict liability was never an option. This builds on the general principle that states may presume that recipient states will use their aid lawfully. ${ }^{876}$ The final set of comments from governments on the draft text reveals the United States and United Kingdom's concern that responsibility only arise when the participant state intends to facilitate the commission of the wrongful act by its aid. ${ }^{877}$ On first glance, Article 16 requires less than this - the text demands that the aid or assistance be given "with knowledge of the circumstances of the internationally wrongful act.' However, the Commentary also states that the 'aid or assistance must

\footnotetext{
${ }^{873}$ See James Crawford, State Responsibility: The General Part (CUP 2013) 402-403.

${ }^{874}$ See Lowe 'Responsibility for the Conduct of Other States' 5; Nolte and Aust, 'Equivocal Helpers' 12.

${ }^{875}$ See Quigley, 'Complicity in International Law' 108-120.

${ }^{876}$ ARSIWA Commentary on Art 16 [4]; Lowe, 'Responsibility for the Conduct of Other States' 10.

${ }^{877}$ International Law Commission, 'State Responsibility - Comments and Observations Received From Governments’ (2001) UN Doc A/CN.4/515, 27-28.
} 
be given with a view to facilitating the commission of the wrongful act' and that no responsibility arises 'unless the relevant State organ intended, by the aid or assistance given, to facilitate the occurrence of the wrongful conduct...' Evidently, this is a different fault requirement - the textual knowledge standard is subsumed with a standard of wrongful intent. ${ }^{878}$

In many cases, there will not be a great practical difference between a standard of actual knowledge and one of intent. In most situations, where a state provides assistance to another state with the knowledge that the aid will be used to commit a wrongful act, the state's intent that its aid facilitate that act may be inferred. ${ }^{879}$ As Lowe puts it, '[a]s a matter of general legal principle States must be supposed to intend the foreseeable consequences of their acts. ${ }^{, 80}$ Knowledge of intended or ongoing wrongful action by the assisted state will in many cases render that action foreseeable.

There may, however, be cases in which the difference in requirements is dispositive. This is likely to be so when the kind of aid provided is financial and its scale is widespread. Development aid is an example. ${ }^{881}$ State A might provide hundreds of millions of dollars to State B. State B uses some of this money for education, some for health care, some to build infrastructure, and some to purchase weapons. State A knows that State B perpetrates internationally wrongful human

\footnotetext{
${ }^{878}$ Nolte and Aust, 'Equivocal Helpers' 14. This Chapter uses the terminology of knowledge and intent. The standard entailed in the clause 'with a view to facilitating' might also be described as one of purpose. See Chapter 2.5.4.

${ }^{879}$ See Talmon, 'A Plurality of Responsible Actors' 218-219.

${ }^{880}$ Lowe, 'Responsibility for the Conduct of Other States' 8.

${ }^{881}$ See Nolte and Aust, 'Equivocal Helpers' 14-15.
} 
right violations against its citizens, and, in fact, some of the weapons purchased with this aid are used in the commission of those violations. As Nolte and Aust point out, in such a case the aid might have been provided in the knowledge of the circumstances of the wrongful act but not with a view to facilitating it. ${ }^{882}$

At present, there is little judicial practice resolving the ambiguity of the text and Commentary. There is also no agreement among scholars. Nolte and Aust favor the Commentary's prescription of wrongful intent on the basis that a broader standard may discourage beneficial forms of international cooperation. ${ }^{883}$ Lowe favors a standard based on knowledge. ${ }^{884}$ Quigley, writing about the earlier draft Article 27, argues that a restrictive standard of culpability based on intent would undermine the complicity prohibition for two reasons. The first is evidentiary-it is difficult to determine the intention of the participant state. ${ }^{885}$ There is some merit in this argument, though intention may, as in many other instances of intention-based responsibility, be inferred from the facts of the case. ${ }^{886}$

Quigley's second reason for opposing a standard of wrongful intent, or purpose, illustrates an important point about how such a rule would operate. He argues that 'in most situations where a donee State commits an international violation, the donor State does not in fact desire the illegal result. The donor State typically acts out of some other motivation. ${ }^{, 887}$ He uses the example of the US military intervention

\footnotetext{
${ }^{882}$ Ibid 15.

${ }^{883}$ Ibid 14-15.

${ }^{884}$ Lowe, 'Responsibility for the Conduct of Other States' 8.

${ }^{885}$ Quigley, 'Complicity in International Law' 111.

${ }^{886}$ See Nolte and Aust, 'Equivocal Helpers' 15.

${ }^{887}$ Quigley, 'Complicity in International Law' 111 (emphasis added).
} 
in Lebanon in 1958 where Germany allowed the US the use of military bases. He argues that Germany's actions would fall outside a complicity rule based on intent because 'it is unlikely that Germany desired US intervention in Lebanon. ${ }^{888}$ His interpretation is incorrect; desire would not be required, even for a standard based on wrongful intent. For such a standard, it does not matter whether the complicit actor desired the outcome, but rather whether it intended that its aid facilitated or contributed to the action. This would have been the case in respect of Germany's provision of military bases.

With those qualifications in mind, what should be the applicable standard? For one, the text of the Articles, in the absence of the Commentary, points to a standard of knowledge. The argument that this standard would hamper beneficial cooperation is susceptible to challenge. In the first place, it bears repeating that knowledge is quite different from a standard of strict liability or even negligence- $\mathrm{a}$ significant form of culpability is still required. Second, states that are concerned about potential international responsibility in their provision of assistance may mitigate this risk through conditions or more targeted aid. The assisting state may know that the assisted state is in ongoing breach of obligations in one particular area of administration, but may nonetheless want to grant aid for other worthy projects. By imposing a burden on assisting states to ensure that its aid is used lawfully, a standard of knowledge promotes the twin goals of compliance and cooperation. Cooperation is beneficial. Compliance with international law is also beneficial. A standard of knowledge promotes compliance without unduly hampering cooperation.

${ }^{888}$ Ibid. 
Two other questions arise about the standard of knowledge. First, in addition to knowledge of the factual circumstances of the wrongful act, must the assisting state also be aware that the act is unlawful? It is doubtful that legal knowledge is required. Mistake of law, even in difficult and contested situations, is no defence for the principal, ${ }^{889}$ and there is no reason that it should be so for the accomplice. Second, does the rule in Article 16 apply in cases of constructive knowledge? In the final round of comments from governments on the draft articles, the Netherlands proposed that Article 16 be changed to read: 'That State does so when it knows or should have known the circumstances of the internationally wrongful act. ${ }^{, 890}$ The Commission did not take up this proposal. At this point, it is unclear how states and institutions will interpret the fault element in Article 16. Lowe argues that an international tribunal would not allow a state to evade responsibility by deliberately failing to inquire into the circumstances of an assisted act where there are clear indications that its assistance would be employed unlawfully. ${ }^{891}$ This is almost certainly correct. Over and above this, international law does not yet recognise a general due diligence obligation conditioning the provision of aid or assistance to another state. ${ }^{892}$

\subsubsection{The Double Obligation Requirement}

\subsubsection{The ILC's Approach}

In addition to the elements of the rule set out above, Article 16 demands that the act committed by the principal state would also be internationally wrongful if committed

\footnotetext{
${ }^{889}$ See André Nollkaemper, 'Concurrence between Individual Responsibility and State Responsibility in International Law' (2003) 52 ICLQ 615, 635.

${ }^{890}$ P.C. Tange, 'Netherlands State Practice for the Parliamentary Year 2000-2001' (2002) 33 Netherlands Y. Intl L. 191, 237 (emphasis added).

${ }^{891}$ Lowe, 'Responsibility for the Conduct of Other States' 10.

${ }^{892}$ Talmon, 'A Plurality of Responsible Actors' 218-219. See also Lowe, 'Responsibility for the Conduct of Other States' 10.
} 
by the complicit state. Where the rule is one of customary international law, both parties will most likely be bound by the obligation. However, with respect to treaty law, this element may limit the scope of the rule. For example, no responsibility arises under Article 16 if China assists the United Kingdom in violating rights guaranteed by European Convention of Human Rights that extend beyond customary international law. ${ }^{893}$ Likewise, a third state may facilitate the breach of a bilateral treaty without incurring responsibility vis-à-vis the injured state.

Chapter 2 of this thesis considered different ways of thinking about the justification for complicity rules in a legal system. On one level, we can see complicity rules as a moral claim. If it is wrong to act in certain way, it is wrong to assist or encourage that act. On another level, we may confine our analysis to legal wrongs - assume only that the principal committed a legal wrong against the victim. Here, in assessing whether a complicity rule is justified, it is helpful to distinguish two sets of relationships between the three parties:

A. V has a right exigible against both $\mathrm{P}$ and $\mathrm{A}$. $\mathrm{P}$, helped by $\mathrm{A}$, violates the correlative duty;

B. V has a right exigible against $\mathrm{P}$ only. $\mathrm{P}$, helped by A, violates the correlative duty. ${ }^{894}$

The rule in Article 16 responds only to the first situation. Certainly, there is a principled reason for prohibiting complicity here — as the Commentary puts it, 'a State cannot do by another what it cannot do by itself. ${ }^{895}$

\footnotetext{
${ }^{893}$ See Crawford, State Responsibility: The General Part 410 in respect of obligations of similar content from different sources.

${ }^{894}$ See generally Hohfeld, 'Fundamental Legal Conceptions' 718-719

${ }^{895}$ ARSIWA Commentary on Art 16 [6].
} 
The question, however, is whether the double obligation requirement unduly limits the rule by excluding the second situation - that is, where $\mathrm{A}$ is not bound by the obligation violated by P. The ILC's inclusion of the double obligation requirement is purportedly based on the pacta tertiis rule, reflected in Articles 34 and 35 of the VCLT $^{896}$ It is fundamental that '[a] treaty does not create either obligations or rights for a third State without its consent. ${ }^{897}$ Two arguments may be raised here. First, it is not clear that the pacta tertiis rule is a ground for distinguishing situations A and B set out above. To explain, consider two alternatives:

i) States A1, P1, and V1 adopt a multilateral treaty (T1) under which each of them agrees not to produce in excess of a certain quantity of steel each year. State P1, assisted by State A1, breaches the obligation;

ii) States P2 and V2 adopt a bilateral treaty (T2) under which each of them agrees not to produce in excess of a certain quantity of steel each year. State P2, assisted by State A2, breaches the obligation.

As noted above, responsibility under Article 16 arises only in the first situation, the purported basis of the distinction being that the bilateral treaty in the second situation cannot give rise to obligations binding State A, whereas this issue does not arise in respect of the multilateral treaty in the first situation. The flaw in this argument is the assumption that the obligation that gives rise to responsibility for State A1 in the first situation is its obligation under the multilateral treaty to refrain from producing steel in excess of a certain quantity. This assumption is wrong. The multilateral treaty does not prohibit complicity in the production of excess steel but rather the act of producing excess steel. In this instance, P1's responsibility arises as a result of its breach of the multilateral treaty; A1's responsibility arises as a result of its breach of Article 16.

\footnotetext{
${ }^{896}$ Ibid.

${ }^{897}$ Art 34 VCLT. See Malgosia Fitzmaurice, 'Third Parties and the Law of Treaties' (2002) 6 Max Planck YB of United Nations L. 37, 38.
} 
In respect of the second situation, the ILC sees the pacta tertiis rule as precluding the possibility of A2's responsibility for complicity. But just as in the first situation, any responsibility imposed on the assisting state would likewise arise under Article 16, rather than for breaching the obligation under the bilateral treaty, a treaty to which, as the ILC rightly points out, it is not party. In other words, in both situations the treaty defines the range of appropriate conduct for the principal state vis-à-vis the victim state and Article 16 defines the range of appropriate conduct for the assisting state vis-à-vis the victim state. Strictly speaking, there is no reason to distinguish the two alternatives on the basis of the VCLT.

This argument is, however, a little misleading: it does not follow from the absence of a basis to distinguish the two situations on account of the pacta tertiis rule that responsibility should arise for complicity where the assisting state is not bound by the obligation breached by the principal state. The desirability of such responsibility must be independently established. As noted above, in those situations where the assisting state $i s$ bound by the same obligation, there is a principled reason for prohibiting its participation in the principal's legal wrong: states should not be able to do by another what they cannot do themselves. ${ }^{898}$ The question is whether there are principled and policy reasons for extending responsibility for complicity to situations where the assisting state is not so bound. ${ }^{899}$

\footnotetext{
${ }^{898}$ ARSIWA Commentary on Art 6 [6].

${ }^{899}$ To be sure, this is not quite the same question as whether the ILC erred in not extending responsibility beyond the double obligation requirement. The latter question also implicates concerns about the ILC's institutional role within the international legal system, the prudence of proceeding cautiously in developing the rules of state responsibility, and the incongruity of the primary nature of Article 16 within a system of secondary rules of state responsibility. See Lowe, 'Responsibility for the Conduct of Other States' 8.
} 


\subsubsection{A General Complicity Rule in the Law of State Responsibility?}

It was argued above that the pacta tertiis rule does not provide a reason to distinguish between situations in which the assisting state is, and is not, bound by the obligation breached by the principal state. We should not deny, however, the relevance of the pacta tertiis rule to determining whether international law should adopt a general complicity rule — that is, one not conditioned by such a double obligation requirement. It is relevant because of the derivative nature of complicity. ${ }^{900}$ Complicity rules do not operate independently of the various substantive obligations binding principal actors. Whenever a principal state undertakes an obligation to do or not do a certain act, the freedom of third states bound by a complicity rule is inevitably affected. As a simple example, imagine State $\mathrm{P}$ is under no obligation to State V not to produce in excess of a certain amount of steel. It is at liberty to produce as much steel as it wishes. State A is free to assist State P's steel production. Now imagine State P undertakes in a treaty with State V not to produce in excess of that amount of steel. If State A is bound by a general complicity rule, it is prohibited from assisting State P's breach of its obligation.

In this sense, a prohibition on complicity in respect of a breach of the treaty between States P and V does implicate the pacta tertiis rule. There is little doubt as to the customary status of the rule. ${ }^{901}$ It is underpinned by the principles of independence and equality of states, and is a consequence of the consensual character

\footnotetext{
${ }^{900}$ See ARSIWA General Commentary on Chapter IV [7].

${ }^{901}$ Eric David, 'Article 34 - General Rule Regarding Third States' in Olivier Corten and Pierre Klein (eds), The Vienna Convention on the Law of Treaties: A Commentary - Volume I (OUP 2011) 887, 888-889.
} 
of treaty relations. ${ }^{902}$ Important as these principles are, particularly in the law of treaties, ${ }^{903}$ they are not the only values operating in the international legal system. As Chinkin puts it, there is 'inevitably a friction between the rigid pacta tertiis rule and the progressive development of normative standards., 904

It is here where the analogy drawn in Chapter 2 to inducing breach of contract in domestic legal systems is helpful. In the first place, the pacta tertiis rule is itself a principle drawn from the Roman law of obligations. ${ }^{905}$ Manifest in modern rules of privity of contract, the principle has been said to protect the 'very freedom of individual action which the common law exists largely to secure, ${ }^{906}$ a municipal echo of the values underpinning the rule in international law, though of course concerning a different legal subject. Second, the brief digression into the inducement tort in Chapter 2 illustrated that the desirability of a complicity rule cannot be settled by appeal to a fundamental principle in one area of law-in municipal law, privity in the law of contract; in international law, the pacta tertiis rule in the law of treaties. What matters are principled and policy reasons shaped by the conflicting needs and purposes of the legal system itself. ${ }^{907}$

In this respect, the double obligation requirement is an undue limitation on the operation of a prohibition on complicity in international law. This weakness in Article 16 may be approached from two directions. First, by allowing third state

\footnotetext{
${ }^{902}$ Ibid 888; Chinkin, Third Parties in International Law 26.

${ }^{903}$ Lowe, 'Responsibility for the Conduct of Other States' 7.

${ }^{904}$ Chinkin, Third Parties in International Law 5.

905 Ibid 26.

${ }^{906}$ Sayre, 'Inducing Breach of Contract' 687.

${ }^{907}$ See Ch. 2.3.2 above. See also Aust, Complicity in the Law of State Responsibility 252.
} 
complicity in these instances, Article 16 fails to give due weight to the relationship between the principal state and the victim state. Here, again, the analogy to inducing breach of contract is helpful. Simester and Chan suggest that promises change the relationship between the two parties to the promise. ${ }^{908}$ Drawing on Raz, they argue that in addition to the performance right arising thereunder, the promise creates for the promisee a 'right to preemptive status in the promisor's reasoning. ${ }^{909} \mathrm{By}$ inducing $\mathrm{P}$ to breach her promise to $\mathrm{V}$, the inducer undermines something of intrinsic value - the relationship between the two parties to the promise. ${ }^{910}$

This argument builds on the moral presuppositions of Raz's idea of promises, namely 'the desirability of special bonds between people and the desirability of special relations that are voluntarily shaped and developed by the choice of participants. ${ }^{911}$ In place of people, we might substitute the term state. When states voluntarily undertake obligations to each other, it creates a special relationship inter se. Between the parties, that relationship is sustained by the foundational principle of pacta sunt servanda. ${ }^{912}$ Although the obligations voluntarily undertaken by the principal parties do not bind a third party, the value of that relationship itself is worthy of protection. That protection may be provided by a complicity rule.

The second direction from which to approach the flaw engendered by the double obligation requirement starts from the needs of the legal system as a whole

\footnotetext{
${ }^{908}$ Simester and Chan, 'Inducing Breach of Contract' 151.

${ }^{909}$ Ibid. See Joseph Raz, 'Promises and Obligations' in PMS Hacker and Joseph Raz, Law, Morality, and Society - Essays in Honour of H.L.A. Hart (Clarendon 1977) 210.

${ }^{910}$ Simester and Chan, 'Inducing Breach of Contract' 151-152.

911 Joseph Raz, ‘Promises in Morality and Law' (1981-1982) 95 Harv. L. Rev. 916, 928.

${ }^{912}$ See Art 26 VCLT; Jean Salmon, 'Article 26: Pacta Sunt Servanda' in Corten \& Klein, The VCLT: A Commentary - Volume I 659.
} 
rather than the specific value of the relationship between the principal parties.

Lanovoy argues that:

[T] he opposability of the obligation on the aiding or assisting State and on the aided or assisted State perpetuates a particular vision of reciprocal normativity without asking whether it is still suitable in the modern state of international law. ${ }^{913}$

On this basis, a rule that recognises the broader community interest in compliance with international law would be desirable. Just as the municipal tort of inducing breach of contract is seen as an assertion of 'society's interest in commercial stability and contractual integrity, ${ }^{914}$ so a broader complicity rule would protect the international community's interests in the stability of international relations and the integrity of treaty commitments. It would protect the validity of international legal obligations. ${ }^{915}$ In this respect, international law would 'endeavour for its own legality. ${ }^{916}$

To bind together those two objections to the double obligation requirement, a practical example from outside of the treaty context may be helpful. Lowe considers the position of a persistent objector to extended security zones in the law of the sea. ${ }^{917}$ State A - the persistent objector-assists State P to wrongfully engage in military activities within the extended security zone of State V. The action is wrongful because State $\mathrm{P}$ has acquiesced in such claims, rendering it bound vis-à-vis State V. ${ }^{918}$

\footnotetext{
${ }^{913}$ Lanovoy, 'Revisiting a Structural Norm' 31.

${ }^{914}$ Danforth, 'Tortious Interference with Contract' 1491.

${ }^{915}$ Lanovoy, 'Revisiting a Structural Norm' 34.

${ }^{916}$ Ibid 32.

${ }^{917}$ Lowe, 'Responsibility for the Conduct of Other States' 7-8.

${ }^{918}$ Ibid.
} 
The double obligation requirement in Article 16 would exclude State A's responsibility on the basis of its persistent objector status.

Lowe rightly asks why this should be the rule. ${ }^{919}$ State A, the persistent objector, assisted the principal state's violation of its obligations. Assuming State A acted with knowledge and made a substantial contribution to the wrong, it should be responsible. It should not be responsible for the wrong committed by $\mathrm{P}$, but rather for its own acts of assistance. The demand for responsibility in this instance is supplied by the logic of complicity: both the wrongs we do, and the wrongs we help or encourage others to do, matter. ${ }^{920}$

\subsubsection{Evaluating the Structure of the Rule in Article 16}

Chapter 2 of this thesis argued that complicity is a particular mode of wrongdoing. For this reason, accomplices should be held responsible for their own contribution to the principal's wrong. The wrong of the principal should not be imputed or attributed to the accomplice.

This is how the rule in Article 16 is structured. Although at some point complicity crosses over into joint commission, ${ }^{921}$ the position under Article 16 is made clear in the Commentary:

In accordance with article 16, the assisting State is responsible for its own act in deliberately assisting another State to breach an international obligation by which they are both bound. It is not responsible, as such, for the act of the assisted State. ${ }^{922}$

\footnotetext{
${ }^{919}$ Ibid.

${ }^{920}$ Ibid 13; Gardner, 'Complicity and Causality' 132.

${ }^{921}$ See Lowe, 'Responsibility for the Conduct of Other States' 4.

${ }^{922}$ ARSIWA Commentary on Art 16 [10].
} 
In the attribution of responsibility, Article 16 is a non-imputational complicity rule.

The consequences of that responsibility as a matter of international law raise difficult questions. Duties of cessation and non-repetition would apply. ${ }^{923}$ There are few difficulties here. ${ }^{924}$ Reparation must be paid. ${ }^{925}$ Calculating the form and scale of reparation is complex. ${ }^{926}$ Here, analogies to domestic prohibitions of wrongful participation are not particularly helpful.

The challenge is to locate the rule in Article 16 within the ordinary principles of reparation set out in Articles 31 and 35-37 ARSIWA. ${ }^{927}$ Article 31 reads as follows:

1. The responsible State is under an obligation to make full reparation for the injury caused by the internationally wrongful act.

2. Injury includes any damage, whether material or moral, caused by the internationally wrongful act of a State.

The causal language in Article 31 is immediately evident. As argued in Chapter 2, complicity is best understood as a form of indirect causal contribution to wrongdoing. ${ }^{928}$ The principal causes the injury; the accomplice makes a causal

\footnotetext{
${ }^{923}$ Art 30 ARSIWA

${ }^{924}$ Aust, Complicity in the Law of State Responsibility 274.

${ }^{925}$ Art 31 ARSIWA.

${ }^{926}$ Aust, Complicity in the Law of State Responsibility 274-276.

${ }^{927}$ See Aust, Complicity in the Law of State Responsibility 274.

${ }^{928}$ See Ch. 2.5.3 above.
} 
contribution to the principal's causing the injury. ${ }^{929}$ Accomplices make 'a difference to the difference that principals make. ${ }^{930}$

On this basis, when State A provides State B with weapons with a view to facilitating State B's bombing of a factory in State C, State A makes a causal contribution to State's B's causing of the injury. How, then, might the complicit state's share of responsibility be determined, a question most pertinent to claims of compensation $?^{931}$ Aust's claim that no abstract formula will work seems correct. ${ }^{932}$ In providing guidance, the ILC introduces some confusion:

[W] here the assistance is a necessary element in the wrongful act in absence of which it could not have occurred, the injury suffered can be concurrently attributed to the assisting and the acting State. In other cases, however, the difference may be very material: the assistance may have been only an incidental factor in the commission of the primary act, and may have contributed only to a minor degree, if at all, to the injury suffered. By assisting another State to commit an internationally wrongful act, a State should not necessarily be held to indemnify the victim for all the consequences of the act, but only for those which... flow from its own conduct. ${ }^{933}$

There are two problems here. To understand them, it is necessary to return to the normative framework of the thesis set up in Chapter 2. There, it was argued that it is helpful to distinguish three kinds of differentiation regarding participation in wrongdoing:
A. Doctrinal differentiation;
B. Differentiation in the attribution of responsibility; and
C. Differentiation in the consequences of responsibility.

\footnotetext{
${ }^{929}$ Gardner, 'Moore on Complicity and Causality' 437-438.

${ }^{930}$ Gardner, 'Complicity and Causality' 128.

${ }^{931}$ Art 36 ARSIWA. See Aust, Complicity in the Law of State Responsibility 278.

932 Aust, Complicity in the Law of State Responsibility 276.

${ }^{933}$ ARSIWA Commentary on Art 16 [10] (footnote omitted).
} 
Doctrinal differentiation distinguishes among participants in wrongdoing at the level of legal doctrine. In respect of complicity, the law recognises the category of accomplice and prescribes certain doctrinal requirements of conduct and fault. This is clearly the case with Article 16 .

Differentiation in the attribution of responsibility distinguishes among participants in wrongdoing at the stage of conviction or responsibility. In a differentiated system the accomplice is held responsible for its own contribution to the principal's wrong, rather than for the wrong of the principal. The Commentary on Article 16 makes clear that the assisting state is responsible for its own act and not for the act of the principal acting state. ${ }^{934}$

Differentiation in the consequences of responsibility distinguishes between accomplices and principals in the imposition of sanction or remedy for wrongful conduct. It might be thought that differentiation of this kind flows from differentiation in the attribution of responsibility. This is not always the case. It is entirely conceivable, though not defensible, that accomplices are held responsible as accomplices, but are then sanctioned or punished as though they committed the wrong.

Here, then, is the first problem in the passage. The Commentary on Article 16 emphasises that the assisting state is responsible for its own act. However, it provides that where that assistance is an essential part of the acting state's wrong, the injury

${ }^{934}$ Ibid. 
may be concurrently attributed to the assisting and acting state. ${ }^{935}$ Concurrent attribution of this kind comes perilously close to undermining Article 16's organising principle of differentiation in the attribution of responsibility. Of course, if states act jointly, they may be held responsible in accordance with Article 47 ARSIWA. ${ }^{936}$ But 'responsibility for aiding and assisting wrongdoing is not at all the same as joint responsibility. ${ }^{937}$ The distinction between principalship and accomplice liability is essential to a proper accounting for wrongdoing. ${ }^{938}$

The second problem in the passage concerns what the ILC does not say. Beyond suggesting that the assisting state will not ordinarily be responsible for all the consequences of the acting state's wrongful act, it does not provide any guidelines for determining the consequences of the complicit state's responsibility. To emphasise, it is crucial that the complicit state is held responsible for its own wrongdoing - that is, its contribution to the injury caused by the acting state. What that quantum looks like will be left to the practice of states and decisions of international institutions. ${ }^{939}$ In terms of compensation, a guiding principle of relative culpability may be useful. The scale of the assistance within the context of the wrongful act and the assisting state's foresight of the damage incurred will be central. ${ }^{940}$

This approach presupposes a rejection of joint and several liability as a general principle in cases of complicity. The normative claim of this thesis argues for

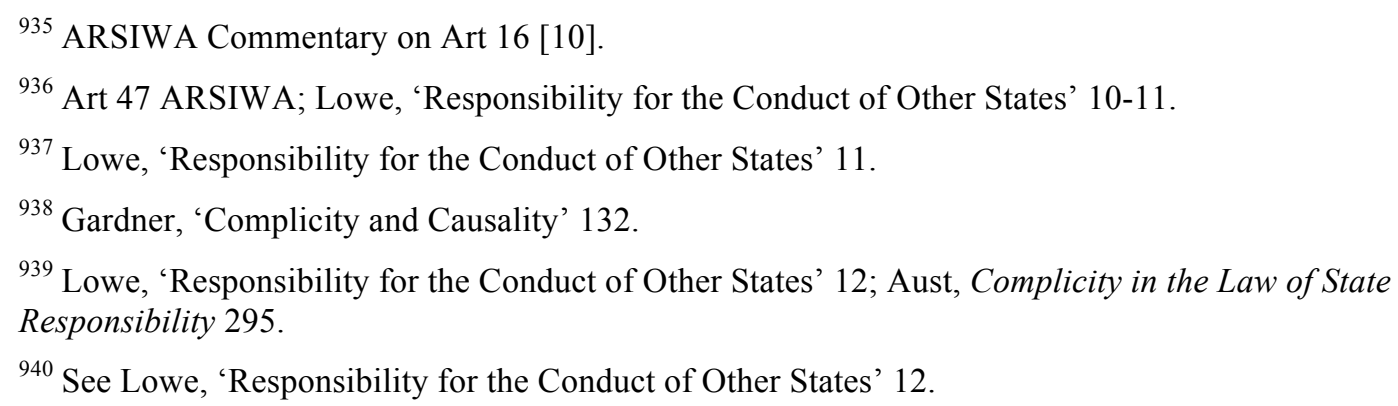


differentiation at each of the three levels set out above. In contrast, joint and several liability abolishes differentiation in the consequences of responsibility. As with individuals, there are principled reasons, underpinned by the idea of sovereignty, for holding states responsible for, and sanctioning them in terms of, their own wrongdoing. ${ }^{941}$ It is doubtful that any policy grounds for joint and several liability in respect of the implementation of international responsibility outweigh these principled reasons. ${ }^{942}$ Moreover, it is not the case that the principle of relative culpability always means that the complicit state will be responsible to a lesser degree than the principal state. There may be situations in which the assisting state is more culpable than the acting state. The essential logic of Article 16-and non-imputational complicity rules more generally—allows for a differentiated assessment of culpability. As Quigley puts it: 'The path to assessing higher or lower damages against a complicit State is left open by the concept that the act of a complicit State is a wrong separate from that of the principal State. ${ }^{, 943}$

\subsubsection{Complicity and the Monetary Gold Principle}

States attempting to invoke the responsibility of a complicit state under Article 16 before an international tribunal may face a procedural problem. The Monetary Gold principle acts as a bar to jurisdiction where, in order to resolve the matter before it, the court must determine the lawfulness of the conduct of a third state without its consent. ${ }^{944}$ The wrongfulness of the principal state's conduct is an essential part of

\footnotetext{
${ }^{941}$ See Nollkaemper and Jacobs, 'Shared Responsibility in International Law' 386; Ch. 2.4.1 above.

${ }^{942}$ Aust, Complicity in the Law of State Responsibility' 296.

${ }^{943}$ Quigley, 'Complicity in International Law' 129. See also Prosecutor v Taylor (Appeals Chamber Decision) [666].

${ }^{944}$ Monetary Gold 32. See also East Timor (Portugal v Australia) [1995] ICJ Rep 90.
} 
Article 16. On this basis, the prospect for enforcing Article 16 before an international tribunal is diminished. ${ }^{945}$

Space precludes a detailed assessment of different interpretations of the Monetary Gold principle and its relationship with Article $16 .{ }^{946}$ It should be reiterated that the principle only operates as a bar to admissibility before international tribunals. $^{947}$ The responsibility of states for complicity persists and may be invoked in the absence of enforcement before an international tribunal. ${ }^{948}$ This is not to downplay the detrimental effect of the absence of enforcement on the international legal system generally, or the damage it may do to the promise of Article $16 .^{949}$ However, as Lowe puts it:

The bonds that tie us most effectively are those of which we are least aware, those with which we comply out of sheer habit. If I am right in believing that Article 16 ascribes responsibility to States, in some circumstances at least, for unlawful acts that are facilitated by the provision of foreign aid... it is likely that before very long it will become a matter of routine in donor States to review the legality of conduct of the recipient State that is materially facilitated by that aid. Such a bureaucratisation of the monitoring of compliance with international law, partial as it might be, would make a significant contribution to the entrenchment of the rule of law in the international community. ${ }^{950}$

\footnotetext{
945 ARSIWA Commentary on Art 16 [11].

${ }^{946}$ See Aust, Complicity in the Law of State Responsibility 296-318.

${ }^{947}$ ARSIWA Commentary on Art 16[11].

${ }^{948}$ Ibid; Aust, Complicity in the Law of State Responsibility 317-318. See also Crawford, 'Second Report on State Responsibility' [174]:
}

Diplomatic protests have been made in cases of wrongful assistance given to another State, and this is proper, since States are entitled to assert complicity in the wrongful conduct of another State even though courts may be incompetent to rule on the charge in the absence of that other State.

\footnotetext{
${ }^{949}$ See Aust, Complicity in the Law of State Responsibility 311.

${ }^{950}$ Lowe, 'Responsibility for the Conduct of Other States' 14.
} 
The bureaucratisation of the monitoring of compliance with international law is minimally affected by the Monetary Gold principle as a procedural bar to the question of jurisdiction much further down the line. As Article 16 becomes part of the day-to-day processes and practices of international law, it has the potential to radically change the ways in which states interact.

\subsubsection{Article 16, the Prohibition on Complicity in Aggression, and Peremptory} Norms of International Law

The first part of this Chapter assessed the rule of international law prohibiting state complicity in aggression. The current part did the same for the rule reflected in Article 16. As this analysis makes clear, the relationship between the two is not one between a primary rule and a secondary rule, but one between a specific primary rule and a general primary rule. The prohibition on complicity in aggression forbids a specific form of state complicity in a specific international wrong. The rule reflected in Article 16 prohibits broader forms of complicity in any international wrong of another state, so long as the obligation at stake is opposable against the complicit state.

The relationship between the two is similar to the relationship between other primary rules of international law. The prohibition on complicity in aggression, alongside any other specific primary complicity obligations binding states, ${ }^{951}$ subsists as an independent obligation regulating state conduct. Different elements of these rules may evolve, ${ }^{952}$ and Article 16 may be used as a reference point for other

\footnotetext{
${ }^{951}$ See Aust, Complicity in the Law of State Responsibility 97-191.

${ }^{952}$ Nolte and Aust, 'Equivocal Helpers' 16-17.
} 
complicity rules. ${ }^{953}$ New rules might arise, imposing stricter standards on states in respect of matters of particularly grave concern. ${ }^{954}$ Together, these rules are a crucial part of, in Aust's phrase, a 'network of rules' relating to states' obligations arising in respect of conduct of other actors. ${ }^{955}$

This network of rules is supplemented by additional obligations that states bear in respect of breaches of peremptory norms of international law, as reflected in Chapter III ARSIWA. ${ }^{956}$ There is an extensive literature concerning the existence and implications of peremptory norms. ${ }^{957}$ A peremptory norm of international law is one 'accepted and recognized by the international community of States as a whole as a norm from which no derogation is permitted and which can be modified only by a subsequent norm of general international law having the same character. ${ }^{958}$ The prohibitions on genocide, aggression, slavery, and torture are commonly understood to be norms of this character. ${ }^{959}$

Article 41 ARSIWA sets out the particular consequences of serious breaches

\footnotetext{
${ }^{953}$ See Bosnian Genocide [420].

${ }^{954}$ Nolte and Aust, 'Equivocal Helpers' 17.

${ }^{955}$ Aust, Complicity in the Law of State Responsibility 376.

${ }^{956}$ Chapter III ARSIWA.

${ }^{957}$ See e.g. Christian Tomuschat and Jean-Marc Thouvenin, The Fundamental Rules of the International Legal Order: Jus Cogens and Obligations Erga Omnes (Martinus Nijhoff 2006); Alexander Orakhelashvili, Peremptory Norms in International Law (OUP 2006); Ulf Linderfalk, 'The Effect of Jus Cogens Norms: Whoever Opened Pandora's Box, Did You Ever Think About the Consequences' (2007) 18 Eur. J. Intl L. 853.

${ }^{958}$ Art 53 VCLT.

${ }^{959}$ See Eric Suy, 'Article 53 - Treaties Conflicting with a Peremptory Norm of General International Law ('jus cogens')' in Olivier Corten and Pierre Klein (eds), The Vienna Convention on the Law of Treaties: A Commentary - Volume II (OUP 2011) 1224; ARSIWA Commentary on Art 40 [4], [5]; Lowe, International Law 58-60.
} 
of peremptory norms. These consequences, almost entirely, ${ }^{960}$ entail obligations on non-responsible states. ${ }^{961}$ In the first place, all states are under an obligation to cooperate in bringing to an end the serious breach. ${ }^{962}$ Secondly, Article 41(2) prescribes that:

No State shall recognize as lawful a situation created by a serious breach within the meaning of article 40 , nor render aid or assistance in maintaining that situation. ${ }^{963}$

The second clause of Article 41(2) supplements the prohibition on aid and assistance in Article 16, dealing "with conduct "after the fact" which assists the responsible state in maintaining' the situation created by the breach. ${ }^{964}$ In contrast to conventional rules of complicity that respond to participation in a particular wrongful act, Article 41(2) defines the principal wrong more broadly as the situation created by the serious breach.

There are interesting questions about the scope of Article 41(2) and its relationship with Article $16 .{ }^{965}$ For present purposes, it is sufficient to note that the rules, together with the specific primary rule prohibiting complicity in aggression by

${ }^{960}$ The obligation of non-recognition applies to all states, including the responsible state. See ARSIWA Commentary on Art 41 [9]:

Under article 41, paragraph 2, no State shall recognize the situation created by the serious breach as lawful. This obligation applies to all States, including the responsible State. There have been cases where the responsible State has sought to consolidate the situation it has created by its own "recognition". Evidently, the responsible State is under an obligation not to recognize or sustain the unlawful situation arising from the breach.

${ }^{961}$ See Christian Tams, 'Do Serious Breaches Give Rise to Any Specific Obligations of the Responsible State’ (2002) 13 Eur. J. Intl L. 1161.

${ }^{962}$ Art 41(1) ARSIWA.

${ }^{963}$ Art 41(2) ARSIWA.

${ }^{964}$ ARSIWA Commentary on Art 41[11].

${ }^{965}$ See Aust, Complicity in the Law of State Responsibility 338-352. 
the provision of territory, are mutually reinforcing. ${ }^{966}$ A state that allows its territory to be used for an act of aggression is itself responsible for an act of aggression. As argued above, this rule is not conditioned by a substantiality requirement in the nexus between the complicit act and the principal wrong - any grant of territory, no matter where the territorial state lies in relation to the victim state, should be sufficient for responsibility. ${ }^{967}$ The general rule, Article 16, prohibits a much broader range of complicit conduct but is subject to a nexus requirement of substantial contribution. ${ }^{968}$ It will ordinarily be the case that territorial complicity of the kind prohibited by the specific rule will also give rise to responsibility under Article 16, though it is possible to envisage immaterial or insignificant complicity of this kind that does not engage Article 16. As the principal act will also constitute a violation of the peremptory rule prohibiting aggression, all states owe obligations of non-assistance in maintaining the situation. ${ }^{969}$

\subsection{CONCLUSION}

States invade other states. They commit human rights abuses, violate arms treaties, and breach environmental obligations. Other states help. Understood solely as a system of bilateral relationships, international law would not respond adequately to complicity as a particular mode of wrongdoing — it would ask states to pay attention only to the wrongs they commit and not to the wrongs they help other states to commit. ${ }^{970}$

\footnotetext{
${ }^{966}$ Nolte and Aust, 'Equivocal Helpers' 16; Nina Jørgensen, 'The Obligation of Non-Assistance to the Responsible State' in Crawford et al (eds), The Law of International Responsibility 687, 692.

${ }^{967}$ See Ch. 7.2.2 above.

${ }^{968}$ ARSIWA Commentary on Art 16 [5].

${ }^{969}$ Art 41(2) ARSIWA. See Nolte and Aust, 'Equivocal Helpers' 16-17.

${ }^{970}$ Lowe, 'Responsibility for the Conduct of Other States' 13; Gardner, 'Complicity and Causality' 132 .
} 
The international legal system is no longer marked by the absence of state complicity rules. The developments analysed in this chapter reflect a move from the specific and piecemeal to the general and principled-from a prohibition on a specific form of complicity in a specific international wrong to a prohibition on aid or assistance in the commission of any international wrong by the recipient state. It is not the end of the road - in particular, influence as a form of complicity, responsibility for complicit omissions, and the double obligation requirement demand further attention. Nonetheless, Article 16 is a great leap towards a principled approach to state complicity in the wrongs of other states. ${ }^{971}$

${ }^{971}$ Lowe, 'Responsibility for the Conduct of Other States' 13. 


\section{CHAPTER 8. STATE COMPLICITY, NON-STATE ACTORS, AND} ATTRIBUTION

\subsection{INTRODUCTION}

The previous chapter considered how international law prohibits state complicity in the commission of an internationally wrongful act by another state, analysing a specific and general complicity rule. States are not, of course, the only actors on the international plane that cause harm to the interests of other states and/or individuals. Non-state actors launch cross border attacks, pollute rivers, and commit genocide. ${ }^{972}$

Quite often, non-state actors carrying out these acts do so with the support of a state. That is to say, the state often stands in a complicit relationship with the nonstate actor. In some instances, state responsibility will arise on the basis of a discrete due diligence obligation to protect against harms caused by non-state actors. Less often, international law imposes direct obligations of non-participation on states. More generally, though, the historical failure of international law to regulate the conduct of non-state actors directly limited the possibility of state responsibility for complicity. There is simply no international wrong for the state to be complicit in. This follows from the historical structure of the international legal system. ${ }^{973}$

The next chapter-Chapter 9-shows how the increased regulation by international law of the conduct of non-state actors has opened up the possibility of states bearing complicity obligations in respect of that conduct. The current chapter addresses an entirely different way that international law addresses state support for the conduct of non-state actors. Here, the putative claim is that a complicit

\footnotetext{
${ }^{972}$ See Hakimi, 'State Bystander Responsibility’ 341.

${ }^{973}$ De Frouville, 'Attribution of Conduct' 276.
} 
relationship between the state and non-state actor is sufficient to attribute its conduct to the state. As will be seen, attribution in international law ordinarily requires an agency relationship. In two contexts - state support for terrorist armed attacks and state support for human rights violations in the Inter-American system - there is a claim that this agency standard has been relaxed to entail a standard based on complicity. This is not quite complicity in the sense defined in Chapter 2. Under such an attributional rule, the state is not held derivatively responsible in relation to another actor's wrongdoing; rather, the conduct of that other actor becomes state conduct on the basis of its acts of support or assistance.

This chapter argues that such a claim should be rejected in both cases. In respect of terrorist armed attacks, it will be seen that there is a better interpretation of the international legal materials, one that does not lower the standard for attribution. In respect of human rights violations in the Inter-American system, it will be argued that there are good reasons for maintaining the general standard based on agency in the rules of attribution. Complicity cannot be properly accounted for by relaxing the rules of attribution in international law. A more fruitful path is the one set out in Chapter 9.

\subsection{ATTRIBUTION IN INTERNATIONAL LAW - BASELINES}

It is foundational to international law that state responsibility requires the attribution of conduct to the state. ${ }^{974}$ The search for attribution is the search for a relationship or connection between the state, as a legal person, and the person or group carrying out

\footnotetext{
${ }^{974}$ Art 2 ARSIWA.
} 
the conduct. ${ }^{975}$ For, as the PCIJ observed in the German Settlers in Poland Advisory Opinion: 'States can act only by and through their agents and representatives."976

As a basic rule, states are responsible for the conduct of their own organs. ${ }^{977}$ The corollary of this rule is the non-attribution of conduct of non-state actors to the state. ${ }^{978}$ As the ILC explains, non-attribution in this instance both limits the responsibility of the state and recognises the autonomy of non-state persons acting on their own account. ${ }^{979}$ De Frouville argues that non-attribution 'ensues above all from a theoretical requirement: attribution can only occur in relation to an autonomous person and autonomy requires that only acts resulting from an exercise of free will can be attributed to it. ${ }^{980}$ Nonetheless, international law does attribute, in limited circumstances, the conduct of non-state actors to the state where there is a sufficient connection between them.

Traditionally, the nature of that connection entails an agency relationship. ${ }^{981}$ Attribution, in this sense, may occur under the test of complete dependence or strict control $^{982}$ — rendering the non-state actor a de facto state organ ${ }^{983}$ —or the

\footnotetext{
${ }^{975}$ ARSIWA Commentary on Article 2 [5].

${ }^{976}$ Certain Questions Relating to Settlers of German Origin in the Territory Ceded by Germany to Poland (Advisory Opinion) [1923] PCIJ Series B, No. 6 [34].

${ }^{977}$ Art 4 ARSIWA.

${ }^{978}$ ARSIWA General Commentary on Chapter II [2], [3].

${ }^{979}$ Ibid.

${ }^{980}$ De Frouville, 'Attribution of Conduct' 261.

${ }^{981}$ See Becker, Terrorism and the State 43-79; Chinkin, Third Parties in International Law 142.

${ }^{982}$ Military and Paramilitary Activities in and against Nicaragua (Nicaragua $v$ United States) (Merits) [1986] ICJ Rep 14 [109]; Bosnian Genocide [392]. See also Stefan Talmon, 'The Responsibility of Outside Powers for Acts of Secessionist Entities' (2009) 58 ICLQ 493, 499.

${ }^{983}$ Art 4 ARSIWA.
} 
subsidiary ${ }^{984}$ test of direction or control of specific conduct. ${ }^{985}$ Both of these tests constitute rules of customary international law. ${ }^{986}$ These tests denote the search for a relationship of principal to agent. ${ }^{987}$

A complicit relationship is thus, on a traditional understanding of the rules of attribution, insufficient to render the conduct of the assisted party conduct of the state. This point was made by Brownlie, acting for the government of Serbia and Montenegro, in the proceedings of the ICJ in the Bosnian Genocide case:

Professor Pellet refers to the assistance and support given to Republika Srpska but not to the issue of control. This is precisely the distinction which the Court made in the Nicaragua case. The financing, organizing, training, supplying and equipping of the contras did not constitute control. ${ }^{988}$

The Court affirmed the need for control, thus rejecting the idea that a complicit relationship may be sufficient to attribute the conduct of non-state groups to the state. ${ }^{989}$ Moreover, the Court held that, in general, the rules for attributing conduct to a state do not vary according the nature of the wrongful act. ${ }^{990}$ As a default position, the tests for attribution remain the same whether the non-state group is committing genocide, violations of the laws of war, or environmental harms. ${ }^{991}$ However, the Court left open the possibility that clearly expressed lex specialis could impose a different standard, potentially of a less demanding nature than that reflected

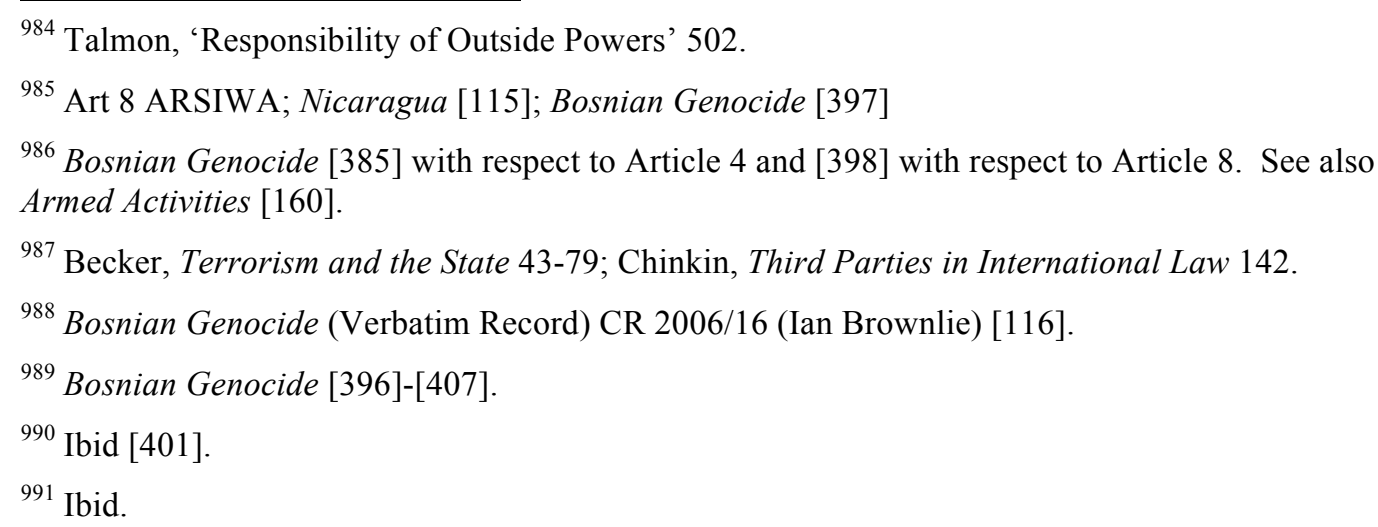


in ARSIWA, under which conduct of a non-state actor may be attributed to the state. $^{992}$ This Chapter considers two putative rules that are said to impose a different standard: state complicity in terrorist armed attacks and state complicity in human rights violations in the Inter-American system.

\subsection{STATE PARTICIPATION IN TERRORIST ATtACKS AND THE RULES OF ATtRIBUTION}

\subsubsection{Introduction}

As noted above, traditionally the attribution of conduct to a state has been defined by the search for a relationship of principal to agent-notions of dependence, instruction, direction, and control are determinative. ${ }^{993}$ A complicit relationship, in its myriad forms, is ordinarily insufficient to attribute the conduct of the non-state actor to the state. $^{994}$ However, an idea persists that the rules of attribution differ in respect of terrorist attacks. This claim is bound up with the requirement of armed attack in the law of self-defence. If an armed attack must be attributable to a state in order to trigger the right of self-defence, then the basis on which the hostile actions of terrorist groups are attributable to the complicit state becomes a central question in the law of self-defence. If an armed attack need not be attributable to the state in order to trigger the right of self-defence, then the international practice set out below puts less pressure on the rules of attribution. The need to show that the state was complicit in the terrorist attack emanating from its territory is diminished. ${ }^{995}$

\footnotetext{
${ }^{992}$ Ibid. See also Art 55 ARSIWA.

${ }^{993}$ Arts 4, 8 ARSIWA.

${ }^{994}$ See Ch. 8.2 above. See also Bosnian Genocide (Verbatim Record) CR 2006/16 (Ian Brownlie) [116].

${ }^{995}$ There remains a residual role for ideas of complicity - see Ch. 8.3.6 below.
} 


\subsubsection{The Approach of the ICJ}

The ICJ has adopted an inter-state reading of the law of self-defence. This requires that the conduct of the non-state actor be attributable to the state to trigger the right to self-defence.

In Nicaragua, the ICJ used Article 3(g) of the Definition of Aggression as a yardstick for interpreting the meaning of the term 'armed attack. ${ }^{, 996}$ In applying Article 3(g), it minimised the application of the final clause of the provision: 'The sending by or on behalf of a State of armed bands, groups, irregulars or mercenaries, which carry out acts of armed force against another State of such gravity as to amount to the acts listed above, or its substantial involvement therein. ${ }^{997}$ Nonetheless, it implicitly left open the possibility that substantial state involvement in the conduct of the armed bands could both breach the prohibition of aggression and constitute an armed attack for the purposes of self-defence. ${ }^{998}$ However, in the Wall Advisory Opinion, after setting out Article 51 of the UN Charter the ICJ stated:

Article 51 of the Charter thus recognizes the existence of an inherent right of self-defence in the case of armed attack by one State against another State. However, Israel does not claim that the attacks against it are imputable to a foreign State.

Consequently, the Court concludes that Article 51 of the Charter has no relevance in this case. ${ }^{999}$

\footnotetext{
${ }^{996}$ Nicaragua [195].

${ }^{997}$ Art 3(g) Definition of Aggression (emphasis added).

${ }^{998}$ See Tom Ruys, 'Armed Attack' and Article 51 of the UN Charter: Evolutions in Customary Law and Practice (CUP 2010) 415-419.

${ }^{999}$ Legal Consequences of the Construction of a Wall in the Occupied Palestinian Territory (Advisory Opinion) [2004] ICJ Rep 136 [139].
} 
This is a clear statement of the inter-state reading of the law of selfdefence. ${ }^{1000}$ This interpretation was not unanimous. Judges Higgins, Kooijmans, and Buergenthal point out that there is nothing in the text of Article 51 that demands that the armed attack be attributable to a state. ${ }^{1001}$ Kooijmans and Buergenthal, in particular, place some weight on the fact that Security Council Resolutions 1368 and 1373 refer to the right of self-defence without referring to an armed attack by a state. ${ }^{1002}$ Higgins, in line with her long-standing academic criticism of this interpretation, simply believes the inter-state reading to be incorrect. ${ }^{1003}$

In the Armed Activities case, the ICJ added a degree of confusion to its prior interpretations. On one hand, the Court stated that it had no need to address whether international law allows for a right of self-defence in response to large-scale attacks by irregular forces. ${ }^{1004}$ On the other hand, it specifically found that the legal and factual circumstances for the exercise of self-defence by Uganda were not made out because the attacks against it by armed bands are not attributable to the Democratic Republic of the Congo. ${ }^{1005}$ However, if the attacks were attributable to the DRC, then it would be an ordinary application of the right of self-defence against armed attacks by states. Given that the attacks were not attributable, the consequent question is

\footnotetext{
${ }^{1000}$ See also Armed Activities [146]. In quoting Article 3(g) of the Definition of Aggression, the Court omits the 'substantial involvement' clause of the provision.

${ }^{1001}$ Wall Advisory Opinion (Separate Opinion of Judge Higgins) [33]; (Separate Opinion of Judge Kooijmans) [35]; (Declaration of Judge Buergenthal) [6].

1002 Separate Opinion of Judge Kooijmans [35]; Declaration of Judge Buergenthal [6].

${ }^{1003}$ Separate Opinion of Judge Higgins [33]; Rosalyn Higgins, Problems and Process: International Law and How We Use It (Clarendon 1994) 250-251.

${ }^{1004}$ Armed Activities [147].

${ }^{1005}$ Ibid [146]-[147].
} 
whether international law permits the exercise of self-defence in any event. This Court implicitly answers this in the negative. ${ }^{1006}$

There is a strong argument that the Court's restrictive interpretation has been overtaken by the practice of states. This point is well put by Judge Simma in his Separate Opinion in the Armed Activities case. ${ }^{1007}$ Indeed, over the last thirty years, states have asserted the right to use force against terrorist targets in other states in situations where the conduct of those non-state actors would not be attributable to the state under the ordinary rules of attribution in the law of state responsibility. ${ }^{1008}$ There are two ways to interpret this emergent norm, the first of which is particularly relevant to the operation of ideas of complicity in international law:

1. A new rule of attribution is operating in the context of state responsibility for the attacks of terrorist groups. This rule of attribution is based on a complicit relationship, rather than one of agency or control, such that an armed attack by a non-state group executed with the support of the state becomes conduct of the state. This preserves the inter-state reading of the law of self-defence; or

2. The inter-state reading of Article 51 and its customary analogue no longer represents international law.

\subsubsection{State Practice in the 1980 s and 1990 s}

Although both interpretations find some support, a review of state practice from the last thirty years indicates that the better interpretation is the latter: the inter-state reading of Article 51 and its customary analogue no longer represents customary international law. In assessing the practice, it makes sense to start with the Schultz

\footnotetext{
${ }^{1006}$ Jörg Kammerhofer, 'The Armed Activities Case and Non-State Actors in Self-Defence Law' (2007) 20 Leiden J. Intl L. 89, 96.

${ }^{1007}$ Armed Activities (Separate Opinion of Judge Simma) [11]. See also Separate Opinion of Judge Kooijmans [16]-[35].

${ }^{1008}$ See generally Ruys, Armed Attack' and Article 51419 -510.
} 
Doctrine, developed and propounded by the United States under President Reagan. ${ }^{1009}$

A central element of the US's approach to terrorism was the claim that force could be used 'against states that support, train, and harbor terrorists or guerillas.' 1010

Following the terrorist attacks on Rome and Vienna Airports in 1985, President

Reagan made the following statement:

By providing material support to terrorist groups which attack U.S. citizens, Libya has engaged in armed aggression against the United States under established principles of international law, just as if [it] had used its own armed forces. ${ }^{1011}$

The clearest manifestation of the Schultz Doctrine in practice is perhaps the attacks by the United States on Sudan and Afghanistan following the 1998 embassy bombings in Kenya and Tanzania. ${ }^{1012}$ There was no assertion that the bombings were carried out by state actors; rather, it was asserted that Afghanistan and Sudan had harboured and supported terrorists. ${ }^{1013}$ Nonetheless, in its letter informing the Security Council of its actions, the US specifically invoked Article 51 of the UN Charter and referred to the bombings as 'armed attacks against United States

\footnotetext{
${ }^{1009}$ See Ruys, Armed Attack and Article 51 421-428.

${ }^{1010}$ US Secretary of State George Schultz, 'Low-Intensity Warfare: the Challenge of Ambiguity’ (15 January 1986) reprinted in (1986) 25 ILM 204, 206. See also Ruys, Armed Attack and Article $51422-$ 423.

${ }^{1011}$ President Ronald Reagan, 'The President's News Conference' (7 January 1986) Public Papers of Ronald Reagan. See also Schultz, 'Low-Intensity Warfare' 206:
}

There is substantial legal authority for the view that a state which supports terrorist or subversive attacks against another state, or which supports or encourages terrorist planning and other activities within its own territory, is responsible for such attacks. Such conduct can amount to an ongoing armed aggression against another state under international law.

${ }^{1012}$ Ruys, Armed Attack and Article 51426.

${ }^{1013}$ President Bill Clinton, 'Address to the Nation on Military Action against Terrorist Sites in Afghanistan and Sudan' (20 August 1998) Public Papers of Bill Clinton. See also Sean Murphy, 'Contemporary Practice of the United States Relating to International Law - 1998' (1999) 93 Am. J. Intl L. 161, 162; Ruth Wedgwood, 'Responding to Terrorism: The Strikes Against Bin Laden' (1999) 24 Yale J. Intl L. 559. 
embassies and United States nationals. ${ }^{1014}$ The response of other states was mixed. $^{1015}$

Scholars have detailed other incidents of state practice throughout the 1990s. ${ }^{1016}$ For instance, in 1992 and 1995, Senegal attacked suspected rebel bases in Guinea-Bissau. $^{1017}$ In 1993, Tajikistan and Russia asserted their right to respond against armed groups operating from Afghanistan, partly on the basis of alleged Afghan participation in the attacks. ${ }^{1018}$ In 1995, Thailand crossed the Burmese border in response to attacks by non-state groups operating out of Burma. ${ }^{1019}$ A year later, Sudan alleged that Eritrea had supported, encouraged, hosted, and sponsored rebel groups hostile to it, and described Eritrea's conduct as a series of aggressive acts. ${ }^{1020}$

\footnotetext{
${ }^{1014}$ Letter dated 20 August 1998 from the Permanent Representative of the United States of America to the United Nations addressed to the President of the Security Council, UN Doc S/1998/780 (20 August 1998).

1015 Jules Lobel, 'The Use of Force to Respond to Terrorist Attacks: The Bombing of Sudan and Afghanistan' (1999) 24 Yale J. Intl L. 537, 538; Murphy, 'Contemporary Practice - 1998' 164-165; Ruys, Armed Attack and Article 51 426-427.

${ }^{1016}$ See e.g. Ruys, Armed Attack and Article 51 428-433; Tom Ruys and Sten Verhoeven, 'Attacks by Private Actors and the Right of Self-Defence' (2005) 10 J. Confl. \& Sec. L. 289, 294-296; Christine Gray, International Law and the Use of Force ( $3^{\text {rd }}$ ed. OUP 2008) 132-143.

${ }^{1017}$ See Gray, International Law and the Use of Force 140.

${ }^{1018}$ Letter dated 15 July 1993 from the Permanent Representative of Tajikistan to the United Nations addressed to the Secretary General, UN Doc S/26092 (16 July 1993); Letter dated 15 July 1993 from the Permanent Representative of the Russian Federation addressed to the Secretary General, UN Doc S/26110 (19 July 1993). See Gray, International Law and the Use of Force 140; Ruys, Armed Attack and Article 51428.

${ }^{1019}$ Keesings (1995) 40554; Gray, International Law and the Use of Force 140.

${ }^{1020}$ Letter dated 13 May 1996 from the Chargé d'Affaires A.I. of the Permanent Mission of the Sudan to the United Nations addressed to the President of the Security Council, UN Doc S/1996/358 (21 May 1996). See also Ruys, Armed Attack and Article 51 428-429; Letter dated 4 December 1996 from the Permanent Representative of the Sudan to the United Nations addressed to the President of the Security Council, UN Doc S/1996/1007 (5 December 1996):
}

The flagrant support of the Eritrean regime to Sudanese terrorist groups, in particular the so-called Sudanese National Alliance, and the facilities it provides for their terrorist activities inside Eritrea is a violation of the Charter of the United Nations and constitutes a threat to regional and international peace and security. 
Since the first Gulf War, Turkey has repeatedly targeted Kurdistan Workers Party interests within Iraq without Iraq's consent. ${ }^{1021}$ In 1995, Turkey defended its use of force on the basis that Iraq had failed to prevent its territory from being used as a staging ground for terrorist attacks, and argued that, consequently, its measures could not be regarded as a violation of Iraq's sovereignty. ${ }^{1022}$ Cross-border operations of this kind followed throughout the late 1990s to a mixed response from states and international institutions. ${ }^{1023}$

Even before the attacks of September 11, 2001, and the response of the international community thereto, the practice surveyed above may illustrate a 'normshaping dynamic going on behind the sound and fury of $[\ldots]$ Charter-invoking claims and counterclaims. ${ }^{1024}$ Nonetheless, a new norm had not fully emerged—-states did express condemnation of many of these operations ${ }^{1025}$ and the prevailing inter-state reading of the law of self-defence probably remained in place.

\subsubsection{A New Era of Terrorism}

The response of the international community to the attacks of September 11, 2001, may be seen as evidence of the crystallisation of the emergent norm discussed

\footnotetext{
${ }^{1021}$ See Gray, International Law and the Use of Force 140-143; Thomas Franck, Recourse to ForceState Action against Threats and Armed Attacks (CUP 2002) 63-64; Ruys, Armed Attack and Article 51 429-433.

${ }^{1022}$ Letter dated 24 July 1995 from the Chargé d'Affaires A.I. of the Permanent Mission of Turkey to the United Nations addressed to the President of the Security Council, UN Doc S/1995/605 (24 July 1995).

${ }^{1023}$ Gray, International Law and the Use of Force 142; Ruys, Armed Attack and Article 51 431-433.

${ }^{1024}$ Franck, Recourse to Force 55.

${ }^{1025}$ See e.g. the statements of Iran, Iraq, Libya, Pakistan, Russia, and Yemen with respect to US bombings of targets in Afghanistan and Sudan - Murphy, 'Contemporary Practice - 1998' 164-165; Letter dated 6 June 2000 from the Permanent Representative of South Africa to the United Nations (as Chair of the Coordinating Bureau of the Non-Aligned Movement) addressed to the Secretary General, UN Doc A/54/917; S/2000/580 [137] (16 June 2000).
} 
above. ${ }^{1026}$ The attacks were carried out by operatives from Al-Qaeda, acting with the support of the Taliban authorities in Afghanistan. ${ }^{1027}$ In the immediate aftermath of the attacks, the Security Council affirmed the right of states to exercise self-defence against terrorist attacks. ${ }^{1028}$ The General Assembly condemned the attacks. ${ }^{1029}$

NATO and the Organization of American States invoked their collective self-defence provisions. ${ }^{1030}$ On October 7, 2001, the United States commenced military action against Afghanistan in the exercise of the right to self-defence triggered by the armed attacks against it. ${ }^{1031}$ A survey of responses from states indicates widespread support for the United States' military action. ${ }^{1032}$

This support was given despite that fact that under the ordinary rules of state responsibility it is unlikely that the conduct of Al-Qaeda was attributable to Afghanistan. ${ }^{1033}$ Interpretations by scholars of the effect of the invasion of Afghanistan on the law of self-defence have varied. Few discount the impact of the

\footnotetext{
${ }^{1026}$ Michael Schmitt, 'Responding to Transnational Terrorism under the Jus ad Bellum: A Normative Framework' in Michael Schmitt and Jelena Pejic (eds.), International Law and Armed Conflict: Exploring the Faultlines - Essays in Honour of Yoram Dinstein (Martinus Nijhoff 2007) 157, 165.

${ }^{1027}$ See Sean Murphy, 'Contemporary Practice of the United States Relating to International Law 2001' (2002) 96 Am. J. Intl L. 237-255.

${ }^{1028}$ UNSC Res 1368 (12 September 2001) UN Doc S/Res/1368. See also Gray, International Law and the Use of Force 193.

${ }^{1029}$ UNGA Res 56/1 (18 September 2001) UN Doc A/Res/56/1.

${ }^{1030}$ North Atlantic Treaty Organization, 'Statement by the North Atlantic Council' (12 September 2001) reprinted in (2001) 40 ILM 1267; Organization of American States, 'Resolution on Terrorist Threat to the Americas' (21 September 2001) reprinted in (2001) 40 ILM 1273. See also Gray, International Law and the Use of Force 193; Dinstein, War, Aggression and Self-Defence 228-229.

${ }^{1031}$ Letter dated 7 October 2001 from the Permanent Representative of the United States of America to the United Nations addressed to the President of the Security Council, UN Doc. S/2001/946 (7 October 2001). See also Letter dated 7 October 2001 from the Chargé d'Affaires A.I. of the Permanent Mission of the United Kingdom of Great Britain and Northern Ireland addressed to the President of the Security Council, UN Doc. S/2001/947 (7 October 2001).

${ }^{1032}$ Murphy, 'Contemporary Practice of the United States - 2001' 248-249.

${ }^{1033}$ Ruys, Armed Attack and Article 51 440; Sean Murphy, 'Terrorism and the Concept of "Armed Attack" in Article 51 of the UN Charter' (2002) 43 Harv. J. Intl L. 41, 46; Dinstein, War, Aggression and Self-Defence 228.
} 
invasion entirely. ${ }^{1034}$ Dinstein argues that the response of the international community dispelled 'all lingering doubts' that armed attacks may emanate from nonstate actors. ${ }^{1035}$ Gray is more cautious, but nonetheless asserts that under certain conditions a right of self-defence does exist against attacks by non-state actors. ${ }^{1036}$ Franck's position is that a state may invoke Article 51 to take forcible action against a state harboring or supporting terrorism, but that the 'quasi-jury' of the Security Council, General Assembly, and International Court of Justice must evaluate the basis of the victim state's claim. ${ }^{1037}$

More recent practice of states repeats the pre-September $11^{\text {th }}$ pattern: the response of the international community to various incursions and statements has been mixed. In 2002, Australian Prime Minister John Howard asserted his country’s right to use preemptive unilateral force against terrorist bases in neighboring South East Asian countries. ${ }^{1038}$ This statement was condemned by Malaysia, Thailand, and the Philippines. ${ }^{1039}$ In 2003, Israel attacked terrorist targets within Syria. Despite the emphasis placed by Israel on Syria's complicity, all members of the Security Council other than Russia, the United Kingdom, and United States condemned the attacks. ${ }^{1040}$

\footnotetext{
${ }^{1034}$ See Ruys, Armed Attack and Article 51442.

${ }^{1035}$ Dinstein, War, Aggression and Self-Defence 227. See also Schmitt, 'Responding to Transnational Terrorism' 165; Frederic Kirgis, 'Israel’s Intensified Military Campaign against Terrorism’ Am. Soc. Intl L. Insight (December 2001); Michael Byers, 'Terrorism, the Use of Force and International Law after 11 September' (2002) 51 ICLQ 401, 408-409.

${ }^{1036}$ Gray, International Law and the Use of Force 199.

${ }^{1037}$ Franck, Recourse to Force 67.

${ }^{1038}$ Tom Allard, 'Pre-emptive Strikes: PM Weights UN Rules Change' Sydney Morning Herald (6 December 2002) < http://www.smh.com.au/articles/2002/12/05/1038950147512.html> accessed 23 July 2013; See also Myint Zan, 'Comment: John Howard's "Pre-emptive Strike Thesis" (2003) 7 J. of South Pac. L. 4. Of course, Howard's remarks raise the issue of pre-emption too, which under conventional interpretations of international law are unlawful.

${ }^{1039}$ See Zan, 'Pre-emptive Strike Thesis' 4.

${ }^{1040}$ UN Doc. S/PV.4836 (5 October 2003). See also Ruys, Armed Attack and Article 51 447-448.
} 
The response of states to Israel's 2006 invasion of Lebanon was more supportive, at least with respect to the right of self-defence. ${ }^{1041}$ In 2007 and 2008, Turkey attacked militants, weapons stores, and bases located in northern Iraq affiliated with the PKK in response to cross-borders attacks by the PKK against Turkey. In this case, the international response was essentially one of condonation. ${ }^{1042}$ Finally, Colombia acted against FARC targets in Ecuador in 2008, prompting condemnation by the OAS and a muted response from other states. ${ }^{1043}$

The law of self-defence remains in a state of flux on this question. The invasion of Afghanistan is the high-point in international recognition of the right of self-defence in response to attacks by non-state actors. Subsequent incidents have demonstrated that the international community is still working out the existence and contours of the emergent norm. Interpreting the practice, however, has important implications for the operation of ideas of complicity in international law.

\subsubsection{The Basis of the Emergent Norm}

If it is the case that states may use force in response to attacks emanating from another state but which are not, on the application of the ordinary rules of state responsibility, attributable to that state, how might this be explained in accordance with existing understandings of the regulation of the use of force? As noted above, there are two possible interpretations. The first posits that a new rule of attribution, defined by complicity rather than agency, has arisen or is in the process of arising.

\footnotetext{
${ }^{1041}$ Ruys, Armed Attacks and Article 51 449-457; Tams, 'Use of Force against Terrorists' 379.

${ }^{1042}$ Tom Ruys, 'Quo Vadit Jus ad Bellum?: A Legal Analysis of Turkey’s Military Operations against the PKK in Northern Iraq' (2008) 9 Melb. J. Intl L. 334, 339-345.

${ }^{1043}$ Permanent Council of the Organization of American States, OAS Doc CP/RES.930 (1632/08) (5 March 2008); Tams 'Use of Force against Terrorists' 380. See also Ruys 'Quo Vadit Jus ad Bellum' 358.
} 
Under this new rule, the armed attack of a private terrorist group is attributed to the participating state - that is, the state providing weapons and financial aid, logistical support, or safe harbour. ${ }^{1044}$ The second interpretation posits that this practice has brought about a change within the law of self-defence specifically. The change is that there is no requirement that an armed attack be attributable to the state to trigger the right of self-defence. ${ }^{1045}$ It is not that the conduct of the non-state actor is attributed to the state, but rather that the armed attack need not come from the state to allow the victim state to act in self-defence.

Some evidence may be found to support the attributional interpretation. The Bush doctrine, in particular, appears to put forward a new attributional rule. ${ }^{1046}$ In his address to a Joint Session of Congress on 20 September, 2001, President Bush stated: 'By aiding and abetting murder, the Taliban regime is committing murder.' 1047 This is echoed in the United States' National Security Strategy of September 2002: 'We make no distinction between terrorists and those who knowingly harbor or provide aid to them. ${ }^{1048}$ In 2006, following Katyusha rocket attacks by Hezbollah, Israel characterised its actions as a 'direct response to an act of war from Lebanon' and held

\footnotetext{
${ }^{1044}$ Tams, 'Use of Force against Terrorists' 385; Carsten Stahn, 'Terrorist Acts as "Armed Attack": The Right to Self-Defence, Article 51 ( $\left.1 \frac{1}{2}\right)$ of the UN Charter, and International Terrorism' (2003) 27 Fletcher For. of World Aff. 35, 37.

${ }^{1045}$ Kimberley Trapp, State Responsibility for International Terrorism (OUP 2009) 45-62; Ruys, Armed Attack and Article 51 493; Dinstein, War, Aggression and Self-Defence 224-230; Thomas Franck 'Terrorism and the Right of Self-Defence' (2001) 98 Am. J. Intl L. 839, 840.

${ }^{1046}$ Steven Ratner, 'Jus ad Bellum and Jus in Bello after September 11' (2002) 96 Am. J. Intl L. 905 , 908.

${ }^{1047}$ President George W. Bush, Address to a Joint Session of Congress and the American People (20 September 2001).

${ }^{1048}$ National Security Strategy of the United States (September 2002) 5.
} 
the government of Lebanon responsible. ${ }^{1049}$ Although Israel's statements are somewhat ambiguous, ${ }^{1050}$ they may be read as invoking a new attributional rule.

However, on the whole, most of the evidence points to the interpretation that denies armed attacks must by attributable to the state to trigger the right of selfdefence. ${ }^{1051}$ In the vast majority of cases, the state using force has not considered the host state to be the author of the attack, and, indeed, has limited its response to terrorist targets. ${ }^{1052}$ In the case of the Turkish strikes in Northern Iraq in 2007 and 2008, for instance, a note to the United Nations Human Rights Council implicitly denies that Turkey viewed Iraq as the author of the terrorist attacks:

The counter-terrorism operation carried out by the Turkish Armed Forces in northern Iraq was limited in scope, geography and duration. It targeted solely the PKK/KONGRA-GEL terrorist presence in the region... Turkey remains a staunch advocate of the territorial integrity and sovereignty of Iraq. ${ }^{1053}$

In addition to accounting more accurately for the practice, there are three other reasons for favouring the non-attributional interpretation of the emergent norm. First, there is value in maintaining the coherence of the framework of secondary attributional rules in international law. Clearly expressed lex specialis may, in rare

\footnotetext{
${ }^{1049}$ UN Doc S/PV.5489, 6, ${ }^{1050}$ Compare Tams 'Use of Force against Terrorists' 379 and Raphaël Van Steenberghe, 'Self-Defence in Response to Attacks by Non-state Actors in the Light of Recent State Practice: A Step Forward?' (2010) 23 Leiden J. Intl L. 183, 194.

${ }^{1051}$ Trapp, State Responsibility for International Terrorism' 59. See also Daniel Bethlehem, 'SelfDefense against an Imminent or Actual Armed Attack by Non-State Actors' (2012) 106 Am. J. Intl L. 770 .

${ }^{1052}$ Ruys, Armed Attack and Article 51493.

${ }^{1053}$ Note Verbale dated 26 March 2008 from the Permanent Mission of Turkey to the United Nations Office at Geneva addressed to the Secretariat of the Human Rights Council, UN Doc A/HRC/7/G/15 (28 March 2008). See also Ruys 'Quo Vadit Jus ad Bellum' 345. It is doubtful that the last clause quoted above makes any legal sense.
} 
cases, give rise to varying rules of attribution. ${ }^{1054}$ However, in deciding whether conduct may be attributable to the state, it is helpful to apply the same rules across different substantive areas of international law. ${ }^{1055}$

Second, in terms of the normative claim of the thesis, we should be wary of holding actors responsible for conduct that they, or their agents, did not, in fact, commit. When the actor is an individual, this claim is sustained by the principle of culpability. ${ }^{1056}$ When the actor is a state, the claim is underpinned by the principle of sovereignty. ${ }^{1057}$ Of course, ideas of commission or perpetration are themselves in need of interpretation, and we may wish to build into them a judgment about responsibility. ${ }^{1058}$ But there is a significant step in attributing the conduct of a principal actor to an accomplice state on the basis of the state's complicity. Such a step denies the status of complicity as a particular mode of wrongdoing.

Third, to the extent that states should be able to strike terrorist targets in states that are harbouring or supporting terrorist groups engaged in armed attacks, they should also be able to strike such targets where the state is simply unable to carry out its due diligence obligations to prevent its territory from being used for such attacks. ${ }^{1059}$ This is a matter of the internal logical consistency of the law of selfdefence. A weak state may be unable to control the activities of terrorist groups

\footnotetext{
${ }^{1054}$ Bosnian Genocide [401].

${ }^{1055}$ See Marko Milanović, 'Self-Defense and Non-State Actors: Indeterminacy and the Jus ad Bellum' (EJIL:Talk!, 21 February 2010) <http://www.ejiltalk.org/self-defense-and-non-state-actorsindeterminacy-and-the-jus-ad-bellum/> accessed 23 July 2013.

${ }^{1056}$ See Ch. 2.4.1 above.

${ }^{1057}$ See Nollkaemper and Jacobs, 'Shared Responsibility in International Law' 386; Ch. 2.4.1 above.

${ }^{1058}$ See Ch. 2.4.1 above.

${ }^{1059}$ See Trapp, State Responsibility for International Terrorism 80-82.
} 
operating on its territory. Such a failure to act probably cannot be seen as complicity and, on the attributional interpretation of the law of self-defence, the failure would not entitle the targeted state to respond. However, from the perspective of the state subject to the terrorist attacks, there is no meaningful difference in the harm it suffers. The second interpretation, which allows states to use force in response to armed attacks not attributable to the host state, at least provides internal coherence to the rule.

\subsubsection{The Residual Role of Complicity}

If the inter-state reading of armed attack has disappeared, why is it that states invoking the right of self-defence sometimes accuse the host state of some form of complicity in the terrorist attacks? ${ }^{1060}$ The answer is found in the ordinary jus ad bellum principle of necessity, applicable to both the customary and Charter rights of self-defence. ${ }^{1061}$ Except in cases of state failure, without a nexus to the host state, whether that be the provision of financial support, the supply of weapons, or guarantee of safe harbour, the use of force against that state is unlikely to be necessary. ${ }^{1062}$ The principle of necessity requires that avenues of cooperation be first pursued; without some responsibility of the host state, the doctrine of necessity thus constrains the targeted state's response. ${ }^{1063}$ Where a state stands in a complicit relationship to the attack, the requirement of necessity is more easily fulfilled.

\footnotetext{
${ }^{1060}$ See Trapp, State Responsibility for International Terrorism 58-59; Van Steenberghe, 'SelfDefence' 199; Ruys, 'Quo Vadit Jus ad Bellum' 357.

${ }^{1061}$ Nicaragua [176]; Nuclear Weapons [41].

${ }^{1062}$ Kimberley Trapp, 'The Use of Force against Terrorists: A Reply to Christian J. Tams' (2009) 20 Eur. J. Intl L. 1049, 1053. Cf Kammerhofer, ‘The Armed Activities Case’ 99.

${ }^{1063}$ Trapp, State Responsibility for International Terrorism 59. See also Armed Activities (Separate Opinions of Judges Simma and Kooijmans). It should be noted that the principle of proportionality will also bear on determinations of whether state infrastructure, rather than the non-state groups only,
} 


\subsubsection{Conclusion}

States that support or harbour terrorist groups will likely violate the obligation to protect within their territory the rights of other states. ${ }^{1064}$ Here, their participation is caught within that broader due diligence obligation. They will also likely violate direct obligations prohibiting state support for terrorism. Security Council Resolution 1373, for instance, obligates state to: 'Refrain from providing any form of support, active or passive, to entities or persons involved in terrorist acts... ${ }^{1065}$ In addition, in an era of renewed focus on terrorism, we have seen a further claim that the idea of complicity is operating in the rules of attribution in international law. This claim posits that a complicit relationship is sufficient to render the non-state actor's conduct state conduct. This claim is not, however, the best interpretation of the relevant state practice. The better view is that the emergent norm allows states to use force in response to attacks by non-state actors. Complicity plays a residual role in informing the principle of necessity.

\subsection{State Participation In Human Rights Violations and the RULES OF}

\section{ATTRIBUTION}

\subsubsection{Introduction}

As argued above, in the law of state responsibility the attribution of conduct of nonstate actors to the state is rooted in agency, not complicity. For attribution on the basis that the non-state actor is a de facto organ of state, a standard of complete

may be targeted. See Kimberley Trapp, 'Back to Basics: Necessity, Proportionality, and the Right of Self-Defence against Non-State Terrorist Actors’ (2007) 56 ICLQ 141, 145-155.

${ }^{1064}$ Island of Palmas.

${ }^{1065}$ UNSC Res 1373 [2(a)]. 
dependence is required. ${ }^{1066}$ For attribution of specific conduct of a non-state actor to the state, effective control is required. ${ }^{1067}$ Under this approach, short of effective control by the state, human rights violations committed by a non-state actor with the assistance of a state official are not attributable to the state itself. However, there is a claim that certain rules of attribution in the context of international human rights law constitute lex specialis with respect to the general rules of state responsibility set out above. Just as in respect of terrorist attacks, this approach seeks to attribute the conduct of a non-state actor to the state on the basis of a complicit relationship, rather than any conception of agency.

This idea of a lex specialis regime of attribution based on complicity has developed within the Inter-American human rights system. As a starting point, the Inter-American system follows the basic structure of negative and positive obligations common to international human rights law. ${ }^{1068}$ In Velasquez Rodriguez, the InterAmerican Court of Human Rights interpreted Article 1(1) of the American Convention ${ }^{1069}$ as imposing obligations on states to (i) 'respect the rights and freedoms recognized by the Convention' and (ii) 'ensure the full and free exercise' of those rights. ${ }^{1070}$ This entails obligations to refrain from violating such rights and to take a range of positive measures to prevent, investigate, and punish human rights violations that are not attributable to the state. ${ }^{1071}$

\footnotetext{
${ }^{1066}$ See Ch. 6.2 above.

${ }^{1067}$ Ibid.

${ }^{1068}$ See UNHRC, 'General Comment 31' [6]-[8]; Velasquez Rodriguez [161]-[167]; Ireland v United Kingdom [239].

${ }^{1069}$ American Convention on Human Rights (adopted 22 November 1969, entered into force 18 July 1978) 1144 UNTS 123.

${ }^{1070}$ Velasquez Rodriguez [165]-[166].

${ }^{1071}$ Ibid.
} 
In assessing an allegation that a state failed to respect the rights guaranteed by the American Convention, attribution (or imputability, in the language of the Court) plays a central role. At its core, as in the general law of state responsibility, is the attribution of the conduct of either de facto or de jure state organs and officials to the state. ${ }^{1072}$ In many cases, the attribution requirement is easily satisfied: it is evident that those who perpetrated the violations were state agents or were under the direct control of the state. However, the Inter-American system has also dealt with instances where the state has supported a non-state actor in its perpetration of human rights violations. It is in these cases that the putative lex specialis rule of attribution has arisen.

It should be noted at this point that state participation of this kind, at least where the principal harm is territorial, would constitute a breach of the state's positive obligations to take measures to prevent violations committed by non-state actors, an obligation conditioned by a due diligence standard. ${ }^{1073}$ In such cases, it is not that the conduct of the non-state actor is itself imputable to the state; rather, the state's own omission in failing to act diligently to prevent it gives rise to responsibility. ${ }^{1074}$ The lex specialis rule of attribution analysed in this section is an attempt by the institutions of the Inter-American system to supplement, in cases of culpable state participation, state responsibility for violations of a positive obligation with attribution of the nonstate actor's conduct to the state.

\footnotetext{
${ }^{1072}$ See Velasquez Rodriguez [169]-[172].

${ }^{1073}$ Ibid [172].

${ }^{1074}$ Ibid.
} 


\subsubsection{Sources of the Rule}

The source of the attributional rule is a dictum of the Inter-American Court in the Paniagua Morales case. ${ }^{1075}$ The case concerned acts of abduction, detention, inhuman treatment, torture, and murder perpetrated in Guatemala in 1987 and 1988. Evidence indicated that members of the state's Treasury Police committed the acts in question. In setting out the law on imputability, the Court stated:

The sole requirement is to demonstrate that the State authorities supported or tolerated infringement of the rights recognized in the Convention. Moreover, the State's international responsibility is also at issue when it does not take the necessary steps under its domestic law to identify and, where appropriate, punish the authors of such violations. ${ }^{1076}$

Given that the case concerned conduct of de jure state officials, ${ }^{1077}$ this assertion was broader than was needed to resolve the case. Nonetheless, it may be read to suggest that a complicit relationship — support or toleration-is sufficient to impute conduct of non-state actors to a state.

The Inter-American Commission subsequently applied the Court's statement in Paniagua Morales in the Riofrio matter. ${ }^{1078}$ In this case, the petitioners asserted that the state of Colombia sponsored, permitted, and covered up the massacre of thirteen individuals by paramilitaries in the municipality of Riofrío. In setting out the law on attribution under the Convention, the Commission stated:

Before turning to the analysis of the alleged violations of the standards of the American Convention, it must be ascertained whether the acts of

\footnotetext{
${ }^{1075}$ Paniagua Morales et al (8 March 1998) Inter-Am. Ct. H.R. (Ser. C) No. 37.

${ }^{1076}$ Ibid [91].

${ }^{1077}$ See ibid [93].

${ }^{1078}$ Riofrio Massacre (6 April 2001) Inter-Am. C. H.R., Report No. 62/01. See John Cerone, 'Human Dignity in the Line of Fire: The Application of International Human Rights Law During Armed Conflict, Occupation, and Peace Operations' (2006) 39 Vand. J. Intl L. 1447.
} 
the individuals implicated in the incident in violating such fundamental rights as the rights to life and humane treatment are attributable to the State of Colombia and therefore call into question its responsibility in accordance with international law. In this regard, the Inter-American Court has noted that it is sufficient to show that the infringement of the rights recognized in the Convention has been supported or tolerated by the government. ${ }^{1079}$

This, then, is an explicit assertion that support or toleration of private human rights violations by state officials is sufficient for attribution of those private acts to the state.

Recently, this question arose again in the Mapiripán Massacre case. ${ }^{1080}$ The case concerned a massacre carried out by paramilitaries in the Colombian municipality of Mapiripán in 1997. Evidence indicated widespread state involvement in the killings. ${ }^{1081}$ In its submissions to the Court, the Commission argued that a complicit relationship was sufficient for attribution:

[T] he acts of private individuals involved in said acts can be attributed to the State and, therefore, entail its responsibility in accordance with international law, for which it is sufficient to prove that there has been support or tolerance by the public authorities in the breach of the rights embodied in the Convention... ${ }^{1082}$

In contrast, Colombia sought to distinguish the acts and omissions of its own agents — for which it accepted responsibility—from those of the paramilitaries.

Indeed, it argued that the attribution of the acts of the paramilitaries 'to the State as if they were its agents ... would be contrary to international law. ${ }^{1083}$ Here, Colombia was referring to the rules of attribution in customary international law, as codified by

\footnotetext{
${ }^{1079}$ Riofrío Massacre [48].

${ }^{1080}$ Mapiripán Massacre (15 September 2005) Inter-Am. Ct. H.R., Series C No. 134 (2005).

${ }^{1081}$ Ibid [96].

1082 Ibid [98.a].

${ }^{1083}$ Ibid [97.b].
} 
the ILC in Chapter II of ARSIWA. ${ }^{1084}$ Colombia distinguished this set of secondary rules from the primary rules defining the content and duration of the obligations imposed by the Convention on state parties. ${ }^{1085}$

Colombia's submission is interesting in its express denial that the InterAmerican Convention prescribes a lex specialis rule of attribution based on complicity. Its position is that state responsibility for the conduct of non-state actors is governed by the agency relationship set out in Nicaragua and reflected in Article 8 ARSIWA. ${ }^{1086}$ This is to say, attribution in international human rights law is the same as the default rules of attribution in international law. In the case at hand, Colombia submitted that given 'there were no instructions or effective control by the State...' the conduct of the non-state group was not attributable to it. ${ }^{1087}$

In its assessment of Colombia's responsibility, the Court explicitly rejected Colombia's argument and asserted that the rule of attribution in the Convention constitutes lex specialis with respect to the general law of state responsibility. ${ }^{1088}$ Setting out the content of the special rule of attribution, the Court is not entirely clear on the standard it requires. It may be said that the following factors, many of which are iterations of the same general idea of state involvement, contributed to the attribution of the private conduct of the paramilitaries to the state: (a) the massacre was carried out with 'full knowledge, logistic preparations and collaboration by the Armed Forces'; (b) the 'massacre could not have been prepared and carried out

\footnotetext{
${ }^{1084}$ Ibid [97.d].

1085 Ibid [97.c].

${ }^{1086}$ Ibid [97.d].

${ }^{1087}$ Ibid [97.e].

${ }^{1088}$ Ibid [107].
} 
without the collaboration, acquiescence, and tolerance' of the Armed Forces; and (c) the 'link' between the Armed Forces and paramilitaries. ${ }^{1089}$ Running through these factors, and through the presentation of the evidence, is the idea that the state was complicit in the massacre. A complicit relationship, in the Court's interpretation, is sufficient for attribution.

A similar approach, albeit one concerning state complicity in the wrongdoing of another state, may be found in the recent case of El-Masri v Macedonia before the European Court of Human Rights. ${ }^{1090}$ The case concerned the rendition, detention, and torture of Khaled El-Masri, a German national, by the Central Intelligence Agency of the United States, and the state of Macedonia's involvement therein. ElMasri was (i) arrested, detained, and ill-treated in Macedonia by Macedonian agents, (ii) handed over to a CIA rendition team at Skopje Airport, where he was tortured, and (iii) rendered to Afghanistan, where he was detained for four months. ${ }^{1091}$

The inhuman and degrading treatment of El-Masri by Macedonian agents in (i) raises few legal difficulties - these are attributable acts of ill-treatment by state agents. Likewise, Macedonia's role in the removal of the applicant in (iii) entails a straightforward application of the non-refoulement obligation stemming from Soering. ${ }^{1092}$ More interesting is the court's approach to the torture of El-Masri at the airport by the CIA rendition team:

\footnotetext{
${ }^{1089}$ Ibid [120]-[123].

${ }^{1090}$ El-Masri v The Former Yugoslav Republic of Macedonia (App 39630/09) (Judgment of 13 December 2012).

${ }^{1091}$ Ibid [195]-[223].

${ }^{1092}$ Ibid [212]-[222]. See also André Nollkaemper, 'The ECtHR Finds Macedonia Responsible in Connection with Torture by the CIA, but on What Basis?' (EJIL:Talk!, 24 December 2012)
} 
The Court must first assess whether the treatment suffered by the applicant at Skopje Airport at the hands of the special CIA rendition team is imputable to the respondent State. In this connection it emphasises that the acts complained of were carried out in the presence of officials of the respondent State and within its jurisdiction. Consequently, the respondent State must be regarded as responsible under the Convention for acts performed by foreign officials on its territory with the acquiescence or connivance of its authorities. ${ }^{1093}$

In other words, Macedonia's complicity in the conduct of another state- the US — was sufficient to attribute that conduct to it. ${ }^{1094}$ El-Masri, under the European Convention, replicates the approach of the Inter-American institutions to the question of attribution in international law.

\subsubsection{Understanding the Attributional Approach}

The question in these cases is whether the conduct at issue is attributable to the state? The prescribed test entails a determination of a complicit relationship — a search for collaboration, support, or coordination. ${ }^{1095}$ This approach attempts to address state complicity in the rules of attribution in international law. ${ }^{1096}$

\footnotetext{
$<$ http://www.ejiltalk.org/the-ecthr-finds-macedonia-responsible-in-connection-with-torture-by-the-ciabut-on-what-basis/> accessed 12 September 2013.

${ }^{1093}$ El-Masri [206]. See [235] and [240] with respect to Art 5 ECHR. See also Mohammed Alzery $v$ Sweden (10 November 2006) UNHRC, CCPR/C/88/D/1416/2005 [11.6] for a similar approach arising out of a similar set of facts:

On the issue of the treatment [of] the author at Bromma airport, the Committee must first assess whether the treatment suffered by the author at the hands of foreign agents is properly imputable to the State party under the terms of the Covenant and under applicable rules of State responsibility. The Committee notes that, at a minimum, a State party is responsible for acts of foreign officials exercising acts of sovereign authority on its territory, if such acts are performed with the consent or acquiescence of the State party. (emphasis added).

${ }^{1094}$ Cf Art 17 ARSIWA. See also Ilașcu and Others v Moldova and Russia (App 48787/99) (2005) 40 EHRR 1030.

${ }^{1095}$ See Riofrío Massacre [48]; Mapiripán Massacre [120]-[123].

${ }^{1096}$ See Cerone, 'Human Dignity in the Line of Fire' 1459-62.
} 
This approach is misguided. In the first place, the decisions reveal, on their own terms, a degree of conceptual confusion regarding the relationship between secondary rules of attribution and primary obligations - either positive or negativethat bind states in international law. A state commits an internationally wrongful act when (a) an act or omission is attributable to it under international law and (b) that act or omission breaches an international obligation of the state. ${ }^{1097}$ These are two separate and necessary stages of inquiry. These decisions seem to misunderstand how attribution operates in the context of positive obligations. ${ }^{1098}$ Claims in relation to positive obligations implicate omissions on the part of the state: the state failed to prevent a violation, or punish private actors who committed it, or take steps to ensure fulfillment of the right. Here, of course, attribution plays a necessarily diminished role: by its very nature a failure on the part of the state to fulfill a positive obligation is conduct of that state. All of the legwork in such a case is done in determining the specific content of the positive obligation to take action and whether it was discharged.

The confusion in the Inter-American approach may be found in the Commission's use in Riofrio of a holding of the Court in Paniagua Morales. The latter case concerned Guatemala's responsibility for actions of its own Treasury Police. The Court's test for determining international responsibility was somewhat ambiguous. ${ }^{1099}$ In the Riofrio matter, the Commission applied this test to determine

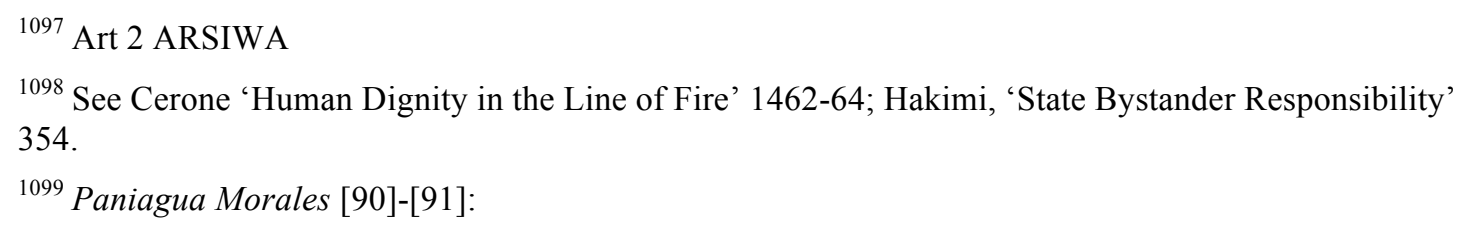

This Court must decide in the present Judgment whether the facts demonstrated may or may not be imputed to the State. This calls for a detailed examination of the conditions in which a particular act or omission that impairs one or more of the rights 
whether or not the actions of non-state actors were attributable to the state of Colombia. ${ }^{1100}$ Underlying the Commission's approach is a flawed premise - that to engage the responsibility of the state under the Convention it is necessary to impute the conduct of the non-state actor to it. But responsibility under the Convention may be engaged by the state's failure to ensure the full and free exercise of rights in the context of violations of those rights by private parties. There is no need to find that the acts of the private party are attributable to state - the relevant state official's failure to act is the attributable act. ${ }^{1101}$

There is another, more charitable, explanation of how this rule developed, one that denies that the Court is confused about the question of attribution in respect of positive obligations. It is most evident in the Mapiripán Massacre case. Faced with the mountain of evidence of the state's involvement, the Court refused to rule that Colombia was responsible only for failing to protect against harm by private actorsthat is, for breach of its positive obligations to protect against violations of the rights at issue. Rather, it was complicit - the state's contribution constituting a particular mode of wrongdoing. A nod towards this understanding may be seen in the judgment of the Court, ${ }^{1102}$ and, more forcefully, in the separate opinion of Judge Cançado Trindade. ${ }^{1103}$

enshrined in the American Convention may be attributed to a State Party and, consequently, calls into question its responsibility in accordance with the rules of international law.

The sole requirement is to demonstrate that the State authorities supported or tolerated infringement of the rights recognized in the Convention.

${ }^{1100}$ Riofrio Massacre [48].

${ }^{1101}$ See Hakimi, 'State Bystander Responsibility' 353-354.

${ }^{1102}$ Mapiripán Massacre [120]-[123].

${ }^{1103}$ Mapiripán Massacre (Separate Opinion of Judge Cançado Trindade). 
Indeed, Judge Cançado Trindade specifically engages Colombia's objection to the attribution of the massacre itself to the state. In the first place, he quotes, perhaps disingenuously given the subsequent work of the commission and requirements of Article 8 ARSIWA, a suggestion by Ago in his Fourth Report on State Responsibility that state 'participation' or 'complicity' may be a sufficient basis for the attribution of private conduct to the state. ${ }^{104}$ Leaving aside this appeal to the authority of Ago, the real source of Judge Cançado Trindade's objection subsequently becomes evident:

There is no way to avoid finding the respondent State responsible for conduct in violation of human rights in the cas d'espèce, nor is it a matter of doing so. To attempt to do this, under the circumstances of the instant case, would involve a fruitless and in abstracto interpretive exercise, devoid of meaning and of juridical value. There is no way to avoid recognizing both the failings and omissions of the public State authorities regarding prevention and conclusive investigation of the violations committed in the instant case, and the support or collaboration provided, directly or indirectly, by public State authorities to the paramilitary, in committing grave violations of human rights under the American Convention. ${ }^{1105}$

The issue for Cançado Trindade is simple: in the light of Colombia's evident participation in the harms at issue, it is not sufficient that responsibility arises only in respect of the state's failure to execute its positive obligations to prevent the harms from arising. Its complicity must be censured and sanctioned by attributing the conduct of the non-state actors to the state.

As in the context of terrorism, there are problems with this approach. First, in terms of the normative claim of the thesis, we should be wary of holding any actor

\footnotetext{
${ }^{1104}$ Mapiripán Massacre (Separate Opinion of Judge Cançado Trindade) [12]. See Roberto Ago, 'Fourth Report on State Responsibility - The Internationally Wrongful Act of the State, Source of International Responsibility' (1978) UN Doc A/CN.4/264 (1978) II YILC 72 [64].

${ }^{1105}$ Mapiripán Massacre (Separate Opinion of Judge Cançado Trindade) [14].
} 
responsible for wrongdoing that it, or its agents, did not, in fact, commit. At stake here is the principle of sovereignty. The tests for attribution reflected in Articles 4 and 8 ARSIWA, bounded as they are by the search for an agency relationship, reflect this claim. It is a significant leap to render an actor that financed or supported a human rights violation responsible for that human rights violation itself. Such a leap denies the status of complicity as a particular mode of wrongdoing.

Second, the approach to attribution in the Inter-American system denies the value of maintaining coherence in the secondary rules of attribution in international law. In matters of this kind, international actors and courts are asking the same question: which acts are state acts? Applying a set of secondary rules across most, if not all, primary rules develops a coherent and certain framework for assessing issues of international responsibility. In other words, short of overwhelming imperative, the attributional rules should not be 'primary rule-dependent., 1106

That said, the approach of the Inter-American institutions is understandable. Although the nature of complicity demands that accomplices are not held responsible for the wrongs of their principals, it also demands that complicity—as a particular way of contributing to such wrongdoing - is prohibited on its own terms. That is to say, we should be not satisfied with sweeping up instances of complicit conduct into a broader due diligence obligation to protect against harm. There is a moral difference between a state failing to put in place the appropriate structures in its police service so as to diligently prevent violations of the right to life, and a state providing weapons to a non-state actor in the knowledge that they will be used to kill civilians. Faced with

${ }^{1106}$ See Milanović, 'Self-Defense and Non-State Actors.' 
evidence of Colombia's participation in the massacre at Mapiripán, the Court chose to condemn that participation by using it, contrary to the general rule in international law, as a ground for attributing the conduct of the non-state group to the state.

In addition, it may be that the normative claim of the thesis carries most weight when the complicit relationship arises between two legal subjects of the same status - individual complicity in the conduct of another individual or state complicity in the conduct of another state. In the present instance, we are dealing with the participation of a state in the conduct of a non-state actor. The difference is entailed not in the fact that the relationship is between two different subjects, but rather in the different nature of that subjectivity in international law. The state is the subject granted primary regulatory authority by international law. ${ }^{1107}$ To consider the state is not only to consider its obligations, but also its powers. In the context of such institutional power, to hold the state responsible for complicity might seem to underweight its culpability. ${ }^{1108}$

This is an interesting argument. Nonetheless, it is not sufficient to displace the principled demand that actors be held responsible only for their own wrongdoing or that of their agents. Moreover, complicity is not necessarily a lesser or more 'marginal' form of responsibility than responsibility for the principal wrong. ${ }^{1109}$ Recognising complicity as a discrete mode of wrongdoing also opens up the

\footnotetext{
${ }^{1107}$ Lowe, International Law 138.

${ }^{1108}$ Amoroso, 'Moving towards Complicity as a Criterion of Attribution' 992-993.

${ }^{1109}$ Cf Amoroso, 'Moving towards Complicity as a Criterion of Attribution' 993. See Ch. 2.4.2 above.
} 
possibility of viewing a certain actor's complicit contribution as more culpable even than the principal's wrongdoing, depending on the circumstances of the case. ${ }^{110}$

In cases of state participation of this kind, rather than loosening the test for attribution, a better solution might be for treaty bodies to interpret the obligationimposing clauses of their respective instruments to impose obligations of nonparticipation on state parties. There is no reason that, for instance, the obligation in Article 1 ECHR to 'secure to everyone within their jurisdiction the rights and freedoms' defined therein cannot be interpreted to include a prohibition on participation in rights violations carried out by other actors. ${ }^{111}$ Such an obligation would capture a form of culpability falling between direct state perpetration and a failure to exercise due diligence to prevent the commission of rights violations.

This interpretive solution, which reads the obligation to refrain from complicity into the rights of the respective conventions, would not be unprecedented. The development of the prohibition on non-refoulement under the European Convention on Human Rights and International Covenant on Civil and Political Rights is somewhat analogous. ${ }^{1112}$ Article 3 ECHR provides: 'No one shall be subjected to torture or to inhuman or degrading treatment or punishment. ${ }^{1113}$ As is the case with other rights, states are under an obligation to refrain from violating the right and to take a range of positive measures to secure its fulfillment. ${ }^{1114}$ Soering $v$

\footnotetext{
${ }^{1110}$ See Quigley, 'Complicity in International Law' 129.

${ }^{1111}$ Art 1 ECHR.

${ }^{1112}$ International Covenant on Civil and Political Rights (adopted 16 December 1966, entered into force 23 March 1976) 999 UNTS 171.

${ }^{1113}$ Art 3 ECHR.

${ }^{1114}$ Robin White and Clare Ovey, Jacobs, White, and Ovey - The European Convention on Human Rights (5 ${ }^{\text {th }}$ ed., OUP 2010) 99-102.
} 
United Kingdom and the line of cases following it establish an additional negative obligation under Article 3: states must refrain from extraditing or deporting a fugitive where there are substantial grounds for believing that the fugitive faces a real risk of torture or inhuman or degrading treatment or punishment in the requesting or recipient country. ${ }^{1115}$ This obligation has also been read into Article 7 ICCPR. ${ }^{1116}$

The point is not that the obligation of non-refoulement is a complicity rule-it arises independently of, and prior to, any subsequent violation in the recipient state. Rather, it demonstrates how a certain right — the right against torture and inhuman and degrading treatment — can be interpreted to give rise to an additional obligation other than the obligation to refrain from direct perpetration of human rights violations. By interpreting the respective instruments to specifically prohibit state participation in violations of human rights by other actors, international human rights institutions would accurately capture and condemn a common form of state culpability in relation to the breach of the right.

Such an interpretation would bolster the modern understanding of rights as giving rise to a tripartite division of correlative duties. In Shue's formulation, every basic right correlates with three duties:

1. Duties to avoid depriving;

2. Duties to protect from deprivation; and

3. Duties to aid the deprived. ${ }^{1117}$

\footnotetext{
${ }^{1115}$ Soering v United Kingdom [89]; Chahal v United Kingdom (App 22414/93) (1996) 23 EHRR 413.

${ }^{1116}$ UNHRC, General Comment 20 [9].

${ }^{1117}$ Henry Shue, Basic Rights - Subsistence, Affluence, and U.S. Foreign Policy $\left(2^{\text {nd }}\right.$ ed., Princeton University Press 1996) 52.
} 
Shue's typology grounds contemporary understandings of human rights as giving rise to obligations to respect, protect, and fulfill. ${ }^{1118}$ The virtue of this approach, in its departure from traditional understandings of rights as negative liberties, cannot be overstated. However, it may be further strengthened by recognising an additional duty of non-participation, falling between the duty to avoid depriving and the duty to protect from deprivation. International human rights law would thereby accurately capture a morally significant and discrete way that states contribute to the commission of rights violations.

\subsection{CONCLUSION}

The rules of attribution in international law in respect of the conduct of non-state actors are marked by a search for an agency relationship between the state and nonstate actor. In two contexts, there is a claim that a complicit relationship, rather than one based on agency, is sufficient to attribute the conduct of the non-state actor to the state. Both should be rejected.

These putative attributional rules are conceptually distinct from complicity in international criminal law, and, indeed, state complicity in the wrongdoing of another state. Unlike the latter two instances, these rules do not seek to tie the accomplice to a separate wrong committed by a principal actor. Instead, they attribute the conduct of the principal actor to the state and, in doing so, give rise to state responsibility for that conduct in terms of the state's own primary obligations.

${ }^{1118}$ See Hakimi, 'State Bystander Responsibility' 346-347. 
By their very nature, attributional rules of this kind cannot comply with the normative claim of the thesis. The normative claim demands that accomplices are held responsible for, and in terms of, their own acts of contribution to the principal's wrong. Responsibility of this kind does not fit easily with the historical structure of international law, simply because of the absence of regulation of the conduct of the non-state actor. Nonetheless, trying to accommodate what looks like ordinary forms of complicity — aid, assistance, or support—within the secondary rules leads to incoherence in the rules of attribution and renders states responsible for conduct that they, or their agents, did not commit. A better solution would be to interpret the rights guaranteed by human rights instruments as imposing a correlative duty of nonparticipation in violations of human rights carried out by other actors. In this way, states would be held responsible for their own contribution to wrongdoing. 


\section{CHAPTER 9. STATE COMPLICITY AND THE OBLIGATIONS OF NON- STATE ACTORS}

\subsection{INTRODUCTION}

It is worth recapping the analysis up to this point. From a starting point marked by an absence of complicity rules, international law has come to prohibit state complicity in the wrongdoing of other states. Specific primary rules such as the prohibition on complicity in aggression subsist alongside the general prohibition on aid or assistance reflected in Article 16 ARSIWA.

Where states participate in harms caused by non-state actors, conceptual problems arise for complicity. The traditional absence of regulation by international law of the conduct of non-state actors means that there is no wrong for the participating state to be complicit in. As noted above, some instances of state participation will be captured under a direct obligation of non-participation or under broader due diligence obligations owed by states in various areas of international law. But in general, complicity, as a particular mode of wrongdoing, is not yet adequately sanctioned by international law.

The previous chapter set out one way in which ideas of complicity bear on international law's regulation of state participation in harms caused by non-state actors. In this approach, what looks like a complicit relationship between the state and the non-state actor would give rise to the attribution of the non-state actor's conduct to the state. This is not accomplice liability in the strict sense, as the state's responsibility is not derived from the non-state actor's wrong. Rather, it takes a factual relationship of complicity as sufficient for attribution. This is a contested and 
undesirable development that is inconsistent with the normative principles set out in Chapter 2 of this thesis.

This chapter analyses a quite different development in the regulation of state complicity. States are no longer the sole bearers of international obligations. Now that other legal subjects bear international obligations, it is possible to articulate states' responsibility for participating in the violation of those obligations in terms of

complicity. ${ }^{1119}$ In other words, there are now certain international wrongs that may be committed by non-state actors as principals, and to which a participating state may be linked as an accomplice. The clearest example in this regard is the prohibition on state complicity in genocide.

The prohibition on state complicity in genocide is a specific complicity rule. This chapter assesses the content of that rule within the analytical framework of the thesis and evaluates its structure. This chapter also raises the possibility that the evolution from specific rules to a general rule seen in respect of state complicity in the wrongdoing of another state will be repeated here. Wherever international law imposes obligations on non-state actors, so state complicity in violations thereof would give rise to international responsibility.

\subsection{State Complicity in Genocide - A Specific Rule}

\subsubsection{Introduction}

The Convention on the Prevention and Punishment of the Crime of Genocideadopted by the General Assembly in 1948 and ratified by the required twenty states in

${ }^{1119}$ De Frouville, 'Attribution of Conduct' 277. 
1950 - envisaged a system of domestic criminalisation and punishment of genocide.

Article I of the Convention provides:

The Contracting Parties confirm that genocide, whether committed in time of peace or in time of war, is a crime under international law which they undertake to prevent and to punish. ${ }^{120}$

There is no textual reference to an obligation prohibiting states from committing genocide, let alone complicity in genocide. Article IX of the Convention, however, makes provision for the International Court of Justice to resolve disputes arising between state parties. In the Bosnian Genocide case, the Court was called upon to determine what obligations the Convention imposes on state parties.

Briefly, the factual foundation of the complicity question in the case lay in the provision by the Federal Republic of Yugoslavia of political, financial, and military aid to authorities of Republika Srpska - a non-state entity in Bosnia and Herzegovina. This aid was used in the commission of genocide by the army of Republika Srpska against the adult male Muslim population of Srebrenica. Thus, one question for the Court was whether the FRY was complicit in the genocide perpetrated by Republika Srpska. ${ }^{1121}$ Before answering this question, the Court obviously had to decide whether the Genocide Convention imposed such a complicity obligation.

\subsubsection{The Reasoning of the ICJ}

The ICJ found that the Genocide Convention did indeed impose an obligation on states not to be complicit in genocide. ${ }^{1122}$ The logical moves made by the Court in

\footnotetext{
${ }^{1120}$ Art I Genocide Convention

${ }^{1121}$ Bosnian Genocide [418]-[424].

${ }^{1122}$ Ibid [167].
} 
this respect are important and have potential ramifications for the interpretation of treaty obligations in other contexts. Against the respondent's objection that duties in the Convention relate only to genocide 'when this crime is committed by individuals, ${ }^{1123}$ the Court found that states are themselves bound by an obligation not to commit genocide. By its reasoning, this prohibition flows from two sources: (i) by categorising genocide as 'a crime under international law', logically states must be undertaking not to commit the act so described, and (ii) the obligation to prevent genocide imposed by the Convention necessarily implies an obligation not to perpetrate genocide. $^{1124}$

The Court then applied this reasoning to the other punishable acts listed in Article III of the Convention, namely conspiracy, direct and public incitement, and attempt to commit genocide, as well as complicity in genocide:

That conclusion must also apply to the other acts enumerated in Article III. Those acts are forbidden along with genocide itself in the list included in Article III. They are referred to equally with genocide in Article IX and without being characterized as "punishable"; and the "purely humanitarian and civilizing purpose" of the Convention may be seen as being promoted by the fact that States are subject to that full set of obligations, supporting their undertaking to prevent genocide. ${ }^{1125}$

On the basis of this reasoning, state parties to the Genocide Convention are obligated to refrain from acts constituting complicity in genocide. It does not matter if the genocide is attributable to another state or committed by a non-state actor. Customary international law also imposes a discrete obligation on states not to

\footnotetext{
${ }^{1123}$ Ibid [156].

${ }^{1124}$ Ibid [166].

${ }^{1125}$ Ibid [167].
} 
commit genocide. ${ }^{1126}$ In principle, the content of the customary obligation may differ from that imposed by the Convention. However, the Convention and interpretations thereof will serve as the main reference point for determinations of the customary obligation. ${ }^{1127}$ Customary international law should be seen to prohibit complicity in genocide too.

\subsubsection{Criticism of the Court's Approach}

Both the first stage - the finding that the Convention prohibits states from committing genocide - and the second stage - the extension of this finding to the other punishable acts listed in Article III — of the Court's reasoning have been criticised. In respect of the first stage, the Joint Declaration of Judges Shi and Koroma in the case explicitly rejects the majority's finding that Article I, read in the light of the purpose and objects of the Convention, may found the obligation not to commit genocide:

Hence, Article I of the Convention has to be interpreted in the light of Article VI and the attempt in the Judgment to sever Article I of the Convention from Articles IV, V, VI, VII and VIII, in order to reach the outcome stated in the Judgment, is to us legally unsustainable and contrary to the object and purpose of the Convention, the meaning of the text of the Convention and the real intention of the parties. ${ }^{1128}$

Their argument is premised on the essential criminal nature of the Convention. This approach is echoed in the separate opinions of Judges Owada ${ }^{129}$ and Tomka. ${ }^{1130}$ Academic criticism, most notably by Gaeta, has argued that the Court's approach to

\footnotetext{
1126 John Quigley, The Genocide Convention: An International Law Analysis (Ashgate 2006) 80; Paola Gaeta, 'On What Conditions Can a State Be Held Responsible for Genocide' (2007) 18 Eur. J. Intl L. 631,632 .

${ }^{1127}$ Krstić (Trial Chamber Judgment) [541].

${ }^{1128}$ Bosnian Genocide (Joint Declaration of Judges Shi and Koroma) [4].

${ }^{1129}$ Bosnian Genocide (Separate Opinion of Judge Owada) [38]-[56].

${ }^{1130}$ Bosnian Genocide (Separate Opinion of Judge Tomka) [40]-[45].
} 
Article I is at odds with both the historical context of the Genocide Convention and ordinary methods of treaty interpretation. ${ }^{1131}$

This criticism has merit. The Convention does not expressly impose an obligation on states not to commit genocide and is, indeed, primarily concerned with individual responsibility through domestic criminalisation. This much is conceded even by those scholars who support the imposition of state responsibility for genocide under the Convention. ${ }^{1132}$ Moreover, some of the arguments relied on by the Court are weak. For instance, the Court appears to place some weight on the fact that there is no conceptual difficulty in interpreting the Convention to impose both individual criminal liability and state responsibility; this potential duality of responsibility is affirmed in both the Rome Statute and ARSIWA. ${ }^{1133}$ This point is strongly rebutted by Judge Owada: the question is not whether international law envisages potential duality of responsibility — a proposition few argue against — but whether the Genocide Convention itself does so. ${ }^{1134}$

In addition, the Court's central, teleological argument is somewhat slippery. It seems right that interpreting Article I to prohibit states from committing genocide would serve the purpose of liberating mankind from the scourge of genocide. ${ }^{135}$ Moreover, the Court's interpretation imposes a coherent set of obligations on state

\footnotetext{
${ }^{1131}$ Gaeta, 'On What Conditions' 633.

${ }^{1132}$ See e.g. Antonio Cassese, 'On the Use of Criminal Law Notions in Determining State Responsibility for Genocide’ (2007) 5 J. Intl Crim. Just. 875, 876-877.

${ }^{1133}$ Bosnian Genocide [173], referencing Art 25(4) Rome Statute and Article 58 ARSIWA.

${ }^{1134}$ Bosnian Genocide (Separate Opinion of Judge Owada) [56].

${ }^{1135}$ See Cassese, 'On the Use of Criminal Law Notions' 877.
} 
parties in relation to genocide. ${ }^{1136}$ In relying so heavily on the object and purpose of the Convention, the Court, in essence, makes this a matter of the permissible breadth of teleological interpretation. The travaux preparatoires are ambiguous at best. ${ }^{1137}$ It may be argued that rather than using the object and purpose of the Convention to interpret the content of obligations imposed thereunder, the Court infers an entirely discrete obligation. ${ }^{1138}$ The obligation to prevent wrongful conduct is distinct from the obligation not to perpetrate or support it. Of course, where a state is complicit in, or indeed perpetrates, the wrong it is required to prevent, international responsibility for the breach of its obligation to prevent will arise. ${ }^{1139}$ But, as a matter of law if not logic, that is a different proposition from implying an obligation not to perpetrate wrongful conduct from the obligation to prevent it.

The Court's teleological construction leads it to rely less directly on the wording of Article IX, which provides a stronger textual argument for the imposition of state responsibility under the Convention. Article IX, the compromissory clause, grants jurisdiction to the ICJ in matters 'relating to the interpretation, application or fulfillment of the present Convention, including those relating to the responsibility of a State for genocide or for any of the other acts enumerated in article III..., ${ }^{1140}$ The clause 'including those relating to the responsibility of a State...' was adopted as an amendment to the working draft on the proposal of the United Kingdom and

\footnotetext{
${ }^{1136}$ Ibid 877-878.

${ }^{1137}$ See Bosnian Genocide [164]-[165], [176]-[178]; Separate Opinion of Judge Owada [59]-[71]; Schabas, Genocide in International Law 491-499; Nina Jørgensen, 'State Responsibility and the 1948 Genocide Convention' in Guy Goodwin-Gill and Stefan Talmon (eds), The Reality of International Law - Essays in Honour of Ian Brownlie (OUP 1999) 273, 290.

${ }^{1138}$ Gaeta, 'On What Conditions' 639.

${ }^{1139}$ Bosnian Genocide [382].

${ }^{1140}$ Art IX Genocide Convention.
} 
Belgium. ${ }^{141}$ Of course, as a compromissory clause, Article IX does not itself impose substantive obligations on states. However, to the extent that the travaux preparatoires concerning the obligations imposed by the operative articles of the Convention are ambiguous, this direct reference to state responsibility may be seen as dispositive. ${ }^{1142}$ Although this issue was always going to be a difficult question of interpretation, greater reliance on Article IX would have been more convincing.

The second stage of the Court's reasoning - extending the obligations on states to include the other enumerated acts in Article III of the Convention-has also been criticised by scholars, although not as widely as the first stage. Most notably, Cassese questions 'this remarkable extension of contracting states' obligations under the Convention. It simply and tersely refers to the object and scope of the Convention. Can this means of interpretation justify such a sweeping conclusion? ${ }^{1143}$ Without answering this question directly, Cassese suggests that this expansive approach is inconsistent with the Court's more restrained answers to other questions of international responsibility, particularly its rejection of the Tadić test of overall control. $^{1144}$

Cassese's criticism of the second stage of the Court's reasoning is better read as an argument for a more expansive approach to the test of control necessary for attribution rather than as a plea for restrained interpretation of the obligations imposed

\footnotetext{
${ }^{1141}$ Schabas, Genocide in International Law 496-497.

${ }^{1142}$ Marko Milanović, 'State Responsibility for Genocide’ (2006) 17 Eur. J. Intl L. 553, 566.

${ }^{1143}$ Cassese, 'On the Use of Criminal Law Notions' 878.

${ }^{1144}$ Ibid 878.
} 
by the Genocide Convention. Surely, if one accepts, as Cassese does, ${ }^{1145}$ a reading of the Convention that imposes an obligation on state parties not to commit genocide, it would be paradoxical not to accept that such an obligation exists also in respect of the other related acts set out therein. This reading is confirmed by the textual reference to the other acts enumerated in Article III in the clause added to Article IX by the amendment offered by the United Kingdom and Belgium. ${ }^{1146}$ All of the legwork of the Court's approach lies in the first stage - finding that the Genocide Convention provides for state responsibility for genocide itself. Once the Court made this ruling, it was always going to find that the Convention prohibits state incitement, conspiracy, attempts, and complicity.

\subsubsection{The Content of the Rule - The Court's Approach}

When, then, will state responsibility for complicity in genocide arise? In the first place, the Court holds that complicity certainly 'includes the provision of means to enable or facilitate the commission of the crime. ${ }^{1147}$ Developing this idea, the Court turns to Article 16 ARSIWA, which prohibits the provision by one state to another of aid or assistance in the commission of an internationally wrongful act:

The Court sees no reason to make any distinction of substance between "complicity in genocide", within the meaning of Article III, paragraph (e), of the Convention, and the "aid or assistance" of a State in the commission of a wrongful act by another State within the meaning of the aforementioned Article 16... In other words, to ascertain whether the Respondent is responsible for "complicity in genocide" within the meaning of Article III, paragraph (e) ... it must examine whether organs of the respondent State, or persons acting on its instructions or under its direction or effective control, furnished "aid or assistance" in the commission of the genocide in Srebrenica, in a sense not

\footnotetext{
${ }^{1145}$ Ibid 877.

${ }^{1146}$ Art IX Genocide Convention.

${ }^{1147}$ Bosnian Genocide [419].
} 
significantly different from that of those concepts in the general law of international responsibility. ${ }^{1148}$

Clearly, the Court locates the prohibition of complicity in genocide within the general law of international responsibility for aid and assistance. In terms of the conduct prohibited by the complicity rule, the Court refers to 'quite substantial aid of a political, military and financial nature provided by the FRY to the Republika Srpska' and its army. ${ }^{1149}$ The flow of aid preceded and continued during the genocide at Srebrenica.

The level of culpability required by the primary rule prohibiting complicity in genocide proved more problematic. Indeed, the Court appeared unsure of how to approach the vexing issue of genocide's dolus specialis, manifest in this regard in the question of the required relationship between the potentially complicit actorSerbia - and the specific intent required for genocide. ${ }^{1150}$ Specifically, does the rule require that the organ or person furnishing aid or assistance to the perpetrator of the genocide share the specific intent of the principal or is it sufficient that the accomplice had knowledge thereof? The Court failed to answer the question, holding that 'at the least' the complicit organ or actor must have acted knowingly; it did not decide if knowledge was, in and of itself, sufficient. ${ }^{1151}$ It was on this basis that the claim failed: it was not established beyond doubt that the FRY continued its provision of aid

\footnotetext{
${ }^{1148}$ Ibid [420].

${ }^{1149}$ Ibid [422].

${ }^{1150}$ Ibid [421].

${ }^{1151}$ Ibid.
} 
with knowledge that the 'perpetrators had the specific intent characterizing genocide, namely, the intent to destroy, in whole or in part, a human group, as such., ${ }^{1152}$

Two points may be made at this stage. First, there are doubts about the accuracy of the Court's factual finding that it was not established beyond doubt that the FRY continued its provision of aid with knowledge that the perpetrators of the genocide were acting with requisite specific intent. ${ }^{1153}$ Vice President Al-Khasawneh, in his dissenting opinion, argues that Belgrade was fully aware of General Mladić's activities in Srebrenica. ${ }^{1154}$ The evidence set out by Judge Keith reinforces this. ${ }^{1155}$ Given this evidence, and the close relationship between the FRY and General Mladić, it is arguable that an inference of knowledge should have arisen.

Second, it is strange that the Court chose not to resolve the requisite level of culpability required for state complicity in genocide. ${ }^{1156}$ It remains unclear whether knowledge of the perpetrator's specific intent or a shared specific intent is required. If the Court had drawn an inference of knowledge from the relationship and meetings between President Milosević and General Mladić, this question, which the Court failed to answer, would have been dispositive of Serbia's legal responsibility for complicity in genocide.

\footnotetext{
${ }^{1152}$ Ibid [422].

${ }^{1153}$ See Cassese, 'On the Use of Criminal Law Notions' 882.

${ }^{1154}$ Bosnian Genocide (Dissenting Opinion of Vice President Al-Khasawneh) [48]-[55].

${ }^{1155}$ Bosnian Genocide (Declaration of Judge Keith) [8]-[16].

${ }^{1156}$ See Milanović, ‘State Responsibility for Genocide: A Follow-Up’ 681.
} 


\subsubsection{Assessing the Rule within the Analytical Framework of the Thesis}

\subsubsection{Introduction}

The analytical framework set out in Chapter 2, as well as the assessment of complicity in international criminal law in Chapter 4, provide a source for insights into the operation of the rule prohibiting state complicity in genocide. At the outset, it is worth reiterating the Genocide Convention's criminal law underpinnings — in Article I 'the Contracting Parties confirm that genocide ... is a crime under international law which they undertake to prevent and to punish. ${ }^{1157}$ The international crime of genocide and accessorial modes of responsibility therein have been fleshed out over the last twenty years in international practice, case law, and scholarship. This raised a methodological question for the ICJ in interpreting the prohibition on state complicity. Should it borrow from international criminal law to determine the meaning of complicity? ${ }^{158}$ Or, as Cassese puts it:

[S]hould the Court instead use those categories (conspiracy, complicity, etc.) as autonomous and self-sufficient public international law categories, that is, regardless of what is prescribed in this regard by international criminal law or by the domestic criminal law system of the relevant state? ${ }^{1159}$

\subsubsection{The Conduct Element}

To reiterate, the Court was faced in the Bosnian Genocide case with text that prescribed simply that 'complicity in genocide' was a punishable act. ${ }^{1160}$ In construing the meaning of complicity, its first move was to look to Article 16 ARSIWA rather than to doctrines of complicity developed in international criminal

\footnotetext{
${ }^{1157}$ Art I Genocide Convention.

${ }^{1158}$ See Cassese, 'On the Use of Criminal Law Notions' 879.

${ }^{1159}$ Ibid.

${ }^{1160}$ Art III(e) Genocide Convention.
} 
law. ${ }^{1161}$ This is the basis of the holding that the meaning of complicity in the context of genocide did not differ significantly from the provision of 'aid or assistance' under Article $16 .^{1162}$ The question, then, is how the idea of aid or assistance under Article 16 fits with ordinary understandings of the scope of complicity.

Drawing as it does on Article 16, the ICJ's approach seems to deny the possibility of complicity by encouragement or abetment—influence in Kadish's terminology. ${ }^{1163}$ The Court gives the example of the 'provision of means to enable or facilitate the commission of the crime... ${ }^{1164}$ As explained previously, in the ILC's conception, the rule in Article 16 focuses on the provision of different forms of physical assistance - its examples include providing means for the closure of an international water-way, facilitating the abduction of a person on foreign soil, and financing the wrongful activity. ${ }^{1165}$ By looking to Article 16 rather than to international criminal law, the ICJ adopts a limited interpretation of complicity, seemingly ignoring that complicity comprises both the provision of assistance to the principal and influence on the decision of the principal to commit the wrong. In some cases of extreme influence — namely direction and control, or coercion—other forms of international responsibility may arise, at least where the principal actor is another state. ${ }^{1166}$ In addition, in the context of genocide specifically, some forms of influence may also constitute direct and public incitement to genocide. ${ }^{1167}$ The point remains,

\footnotetext{
${ }^{1161}$ Bosnian Genocide [419].

1162 Ibid [420].

${ }^{1163}$ Kadish, 'Complicity, Cause and Blame' 342.

${ }^{1164}$ Bosnian Genocide [419].

${ }^{1165}$ ARSIWA Commentary on Art 16 [1]. See Ch. 7.3.5.1 above.

${ }^{1166}$ Arts 17, 18 ARSIWA.

${ }^{1167}$ Art III(c) Genocide Convention.
} 
however, that state complicity in genocide is limited to a particular kind of complicit conduct.

On one level, this approach is understandable: there is heritage to the idea that instances of influence do not constitute state complicity in international law. As explained in Chapter 7, Roberto Ago traced this position to the conclusions of the Board of Commissioners set up under the Convention of 4 July 1831 between France and the United States regarding potential claims against France for the spoliation of property of US citizens. ${ }^{1168}$ However, the idea that cases of complicit state influence should not give rise to responsibility is generally predicated on the assumption that the principal actor in these instances is another state. This is evident in Ago's own words: '[t]he decision of a sovereign State to adopt a certain course of conduct is certainly its own, even if it has received suggestions and advice from another state, which it was at liberty not to follow.'1169

Even if it is right that international law should not be concerned with cases of influence between sovereign states, ${ }^{1170}$ it does not follow that a state that influences the decision of a non-state actor to commit an international wrong should escape responsibility for complicity. ${ }^{117}$ As an analogy, we might look to the obligations of non-participation encompassed by the prohibition on the use of force and the principle of non-intervention, both of which include classical modes of complicity by influence. Under the former, states are obligated to refrain from '... encouraging the

\footnotetext{
${ }^{1168}$ Ago, 'Seventh Report on State Responsibility' [62]. See Ch. 7.3.5.1 above.

${ }^{1169}$ Ibid [63]. See also ARSIWA General Commentary on Part IV [9]; Quigley, 'Complicity in International Law' 80.

${ }^{1170}$ As argued above, this itself may be susceptible to challenge. See Ch. 7.3.5.1 above.

${ }^{1171}$ See Nollkaemper, 'The Charles Taylor Judgment'.
} 
organization of irregular forces or armed bands, including mercenaries, for incursion into the territory of another State' and 'instigating... acts of civil strife or terrorist acts in another State.' 1172 Under the principle of non-intervention, states may not 'foment [or] incite ... subversive, terrorist or armed activities directed towards the violent overthrow of the regime of another State. ${ }^{, 173}$ In addition, the forms of state participation addressed in UN General Assembly Resolutions on terrorism ordinarily include both instigation and encouragement. ${ }^{1174}$

Clearly, then, international law does indicate concern for the influence of states on the conduct of non-state actors. ${ }^{1175}$ As international law develops to recognise increased possibilities of principal wrongdoing by non-state actors, so the ways in which states might participate in that wrongdoing should be adequately sanctioned. This would include not simply the provision of assistance-or help, in Kadish's terminology—but also complicit influence. ${ }^{1176}$

The exclusion of complicity by influence from the specific rule prohibiting state complicity in genocide (and from the general rule in Article 16) also has implications for the concurrence of international responsibility. ${ }^{1177}$ This point is best illustrated by an example. Imagine a paramilitary group in Canada has rounded up all

\footnotetext{
${ }^{1172}$ Declaration on Friendly Relations (emphasis added); Armed Activities [162]. See Trapp, State Responsibility for International Terrorism 28-32.

${ }^{1173}$ Ibid (emphasis added).

${ }^{1174}$ See e.g. UNGA Res 40/61 (9 December 1985) UN Doc A/RES/40/61; UNGA Res 44/29 (4 December 1989) UN Doc A/RES/44/29; UNGA Res 49/60 (9 December 1994) UN Doc A/RES/49/60; UNGA Res 51/210 (17 December 1996) UN Doc A/RES 51/210; UNGA Res 53/108 (26 January 1999) UN Doc A/RES/53/108.

${ }^{1175}$ See also Nicaragua [220].

${ }^{1176}$ Kadish, 'Complicity, Cause and Blame' 342.

${ }^{1177}$ See Art 25(4) Rome Statute; Art 58 ARSIWA. See also Nollkaemper, 'Concurrence'.
} 
members of a racial minority within Canada. The group has genocidal intentions. A British Army general, with full knowledge of those intentions, ships arms to the group with a view to facilitating the commission of genocide. A US Army general, with full knowledge of the group's intentions, broadcasts a radio message encouraging the division to kill the detainees. Genocide is committed. All else being equal, international responsibility may arise in the following forms:

1. The members of the Canadian paramilitary group perpetrating the killings may be individually criminally responsible;

2. Depending on issues of capacity, proximity, and knowledge, Canada might be responsible for failing to prevent genocide;

3. The British Army general may be individually criminally responsible for complicity (aiding) as a mode of participation in genocide;

4. Assuming attribution, the UK may incur state responsibility for complicity in genocide;

5. The US Army general may be individually criminally responsible for complicity (abetting or instigation) as a mode of participation in genocide;

6. The United States will not incur state responsibility for complicity in genocide.

The exclusion of complicity by influence from the rule means that the United States will not incur state responsibility for complicity in genocide. ${ }^{1178}$ Likewise, if the perpetrators had been a unit of the Canadian military, the United States would not incur responsibility under either the specific rule prohibiting complicity in genocide or the general prohibition on aid or assistance reflected in Article 16 ARSIWA. In other words, there will be attributable acts of state agents that give rise to individual criminal responsibility for complicity in genocide but not state responsibility for complicity in genocide. ${ }^{1179}$

\footnotetext{
${ }^{1178}$ It should be noted that individual and state responsibility for the inchoate wrong of incitement may arise.

${ }^{1179}$ Whether this is a problem for international law (other than the problem that central forms of complicity are not being prohibited) depends on whether one thinks that the obligations binding states
} 
A second issue arising under the conduct element concerns the Court's treatment of omissions. After disposing of the claim that Serbia was complicit in the genocide, the Court went on to consider the differences between the complicity obligation and the obligation to prevent genocide. ${ }^{1180}$ In addition to a difference in the kind of knowledge required of the state for responsibility, the Court found that:

$[C]$ omplicity always requires that some positive action has been taken to furnish aid or assistance to the perpetrators of the genocide, while a violation of the obligation to prevent results from mere failure to adopt and implement suitable measures to prevent genocide from being committed. In other words, while complicity results from commission, violation of the obligation to prevent results from omission... ${ }^{1181}$

The simplicity of the Court's approach, though not without attractions, should be resisted. As argued previously, complicity by omission is doctrinally and normatively supported, both in municipal ${ }^{182}$ and international criminal law. ${ }^{183}$ Think of the cleaner who, in breach of his duty to lock up a bank, intentionally leaves

and individuals in instances of potential concurrent responsibility should be identical in content. On this question, which requires further work, compare Milanović, 'State Responsibility for Genocide' 559-569 with Gaeta, 'On what Conditions' 637. Gaeta's argument, along the following lines, seems convincing:

Indubitably, the Genocide Convention prohibits the crime of genocide, and provides for the individual criminal liability of its perpetrators. Indubitably, this prohibition and the individual criminal liability attaching to it can also be found in customary international law. Nothing, however, warrants the conclusion that for states the prohibition of genocide has exactly the same content as the international prohibition at the criminal level, as instead the Court has simply assumed in its judgment. It is certainly possible to conceive of two forms of responsibility, but - exactly because they have a profoundly different nature - these two forms of responsibility (the criminal responsibility of individuals and that of the state) can be triggered by the infringement of two different primary rules, each one shaped upon the particular nature of their addressees and the consequences of the illegal conduct attributed to them.

\footnotetext{
${ }^{1180}$ Bosnian Genocide [432].

${ }^{1181}$ Ibid.

${ }^{1182}$ See Ch. 2.5.2.2 above.

${ }^{1183}$ See Ch. 5.2 above.
} 
the door open so as to facilitate a break-in. ${ }^{1184}$ He did not simply fail in his duty to lock the door; he was complicit in the robbery.

So should it be with complicity in genocide. ${ }^{1185}$ Many more omissions will violate the obligation to prevent genocide than constitute complicity. Fleshed out, the obligation to prevent genocide requires that states take a range of positive measures. It is conditioned by a due diligence standard, ${ }^{1186}$ and limited by practical and legal restraints binding the state, including resource concerns, geographical proximity, and the state's other legal obligations. ${ }^{1187}$ But in some circumstances, a particularly culpable and proximate omission, where both the mens rea and nexus requirements are met, should also be seen to constitute complicity in genocide. ${ }^{1188}$ Here, the state is more directly tied to the actual harm that results. ${ }^{1189}$ In this way, international law will accurately condemn and sanction the increased wrongdoing entailed in a complicit omission.

\subsubsection{The Nexus Element}

Chapter 2 argued that a substantiality requirement ought to condition complicity rules. ${ }^{1190}$ In the Bosnian Genocide case, the ICJ pays little attention to the connection between the complicit state's assistance and the principal's wrong, though in its factual assessment it does refer to 'the quite substantial aid of a political, military and

\footnotetext{
${ }^{1184}$ See Ashworth, Principles of Criminal Law 410-411.

${ }^{1185}$ See Cassese, 'On the Use of Criminal Law Notions' 883-887.

${ }^{1186}$ Ibid [430].

${ }^{1187}$ Ibid.

${ }^{1188}$ See Nina Jørgensen, 'Complicity in Genocide and the Duality of Responsibility' in Bert Swart, Alexander Zahar and Göran Sluiter (eds), The Legacy of the International Criminal Tribunal for the Former Yugoslavia (OUP 2011) 247, 268-270.

${ }^{1189}$ Fletcher, Rethinking Criminal Law 422-423.

${ }^{1190}$ See Ch. 2.5.3 above.
} 
financial nature provided by the FRY to the Republika Srpska and the VRS...' in the lead up to Srebrenica. ${ }^{1191}$ As noted above, the Court found that complicity for the purposes of state complicity in genocide does not differ significantly from the concept of aid or assistance in the law of state responsibility. ${ }^{1192}$ For this reason, it can implicitly be read to endorse the nexus requirement in the Article 16. Although the text of Article 16 is silent on the level of contribution, the Commentary provides as follows:

There is no requirement that the aid or assistance should have been essential to the performance of the internationally wrongful act; it is sufficient if it contributed significantly to that act. ${ }^{1193}$

Although there are some ambiguities in the rest of the Commentary, the standard of significant contribution is probably the best interpretation. ${ }^{1194}$ This is similar to the legal standard imposed by international criminal law: the accomplice's assistance or encouragement must have a substantial effect on the principal's commission of the crime. ${ }^{1195}$ Given the range of contributions that might fulfill the conduct element of complicity, it would be wise to apply this test to the prohibition on state complicity in genocide.

\subsubsection{The Fault Element}

As noted above, one of the strangest things in the Bosnian Genocide case was the Court's failure to determine authoritatively the requisite fault element for state

\footnotetext{
${ }^{1191}$ Bosnian Genocide [422] (emphasis added).

${ }^{1192}$ Ibid [420].

${ }^{1193}$ ARSIWA Commentary on Art 16 [5].

${ }^{1194}$ See Ch. 7.3.5.2 above.

${ }^{1195}$ See Tadić (Appeals Chamber Judgment) [229]; Simić (Appeals Chamber Judgment) [85]; Mrkšić, Šljivančanin (Appeals Chamber Judgment) [81].
} 
complicity in genocide. ${ }^{1196}$ Instead, the Court held that 'at the least' the complicit actor must have acted knowingly; it did not determine if knowledge was sufficient. ${ }^{1197}$ In determining the appropriate standard, it again will matter whether we look to Article 16 ARSIWA or the requirement of mens rea in international criminal law. ${ }^{1198}$

In respect of Article 16, there is an ongoing dispute as to whether a standard of knowledge or purpose is required. The text requires only that the aid or assistance be given 'with knowledge of the circumstances of the internationally wrongful act...,1199 In interpreting the text, the Commentary suggests that the aid or assistance 'must be given with a view to facilitating the commission of the wrongful act. ${ }^{1200}$ As argued above, there are good reasons to prefer a standard of knowledge in this context. ${ }^{1201}$

A similar debate arises in international criminal law. In customary international law and the case law of the ad hoc tribunals, a standard of knowledge is preferred. Here, amongst different formulations of a similar idea, the test is best expressed as requiring that the complicit party made a 'conscious decision to act in the knowledge that he thereby supports the commission of the crime. ${ }^{1202}$ Article 25(3)(c) of the Rome Statute, on the other hand, requires that assistance be given 'for the purpose of facilitating the commission' of the crime. ${ }^{1203}$

\footnotetext{
${ }^{1196}$ See Milanović, 'State Responsibility for Genocide: A Follow-Up' 681.

${ }^{1197}$ Ibid.

${ }^{1198}$ See Cassese, 'On the Use of Criminal Law Notions' 882-883.

${ }^{1199}$ Art 16 ARSIWA.

1200 ARSIWA Commentary on Art 16 [5].

${ }^{1201}$ See Ch. 7.3.5.2 above.

${ }^{1202}$ Kunarac, Kovač, Vuković (Trial Chamber Judgment).

${ }^{1203}$ Art 25(3)(c) Rome Statute.
} 
Although there may not be too great a distance between purpose and knowledge in many contexts, ${ }^{1204}$ there will be cases where it matters. Proper determination of the appropriate standard for the primary rule prohibiting state complicity in genocide, a matter left open by the ICJ, also bears on the broader issue of concurrence noted above. As argued in Chapter 2, as a general rule complicity obligations should be conditioned by a requirement of knowledge rather than purpose. ${ }^{1205}$ This claim is strengthened in the present context on the basis of the extreme gravity of the principal offence.

\subsubsection{Evaluating the Structure of the Rule}

Non-imputational complicity rules render accomplices responsible for their own contribution to the principal's wrong rather than for the wrong of the principal. As argued in Chapter 2, this structure of complicity is normatively desirable. The prohibition on state complicity in genocide, as interpreted by the ICJ, is clearly a nonimputational rule. The methodological assumptions of the Court make little sense if Serbia's putative complicity would have rendered it responsible for the genocide perpetrated at Srebrenica by Republika Srpska. Rather, such complicity, unproven on the facts, would have given rise to responsibility for complicity in genocide. The complicit state is held responsible for its contribution to the principal's wrong.

\subsubsection{Conclusion}

States commit genocide. They also fail to take reasonable measures, informed by ideas of proximity and due diligence, to prevent acts of genocide from occurring. But

\footnotetext{
${ }^{1204}$ See Talmon, 'A Plurality of Responsible Actors' 218-219; Lowe, 'Responsibility for the Conduct of Other States' 8.

${ }^{1205}$ See Ch. 2.5.4 above.
} 
in other instances, states participate in acts of genocide committed by another actor. That is to say, states are sometimes complicit in genocide.

If genocide were not recognised to be internationally wrongful without reference to the status of the principal perpetrator, it would be impossible to express a state's responsibility for participation in the conduct of non-state actors in terms of complicity. There would be no principal legal wrong for the state to be complicit in. International law's traditional structure would impede the imposition of responsibility for complicity. Instead, international law's recognition of the wrong of genocide enables the articulation of responsibility in terms of complicity. Here, international law understands complicit conduct as a particular way of contributing to wrongdoing, falling between direct state perpetration and a failure to exercise due diligence in preventing the wrong from occurring.

\subsection{A General Rule?}

The obligation not to commit genocide is not the only obligation imposed by international law on non-state actors. The tantalising prospect is that the evolution set out in Chapter 7 regarding state complicity in the wrongful acts of other states-the move from specific complicity rules to a general rule—-will be repeated here. ${ }^{1206}$ As international law comes to recognise additional kinds of wrongdoing by non-state actors, so a general complicity rule would restrain state participation in the commission of that wrongdoing. ${ }^{1207}$

\footnotetext{
${ }^{1206}$ See Vogel, ‘Twelve Models’ 160.

${ }^{1207}$ De Frouville, 'Attribution of Conduct' 277.
} 
This would be an important step in the development of the international legal system. Indeed, the seriousness of the obligations that international law imposes on non-state actors supplies the logic for a complicity rule. Such a rule might be thought of as a non-state analogue to the rule reflected in Article 16. On this basis, it might read:

A State which aids or assists a non-state actor in the commission of an internationally wrongful act by the latter is internationally responsible for doing so if:

(a) the State does so with knowledge of the circumstances of the internationally wrongful act; and

(b) the act would be internationally wrongful if committed by the State. $^{1208}$

As in the rule reflected in Article 16, this non-state analogue would prohibit all forms of complicity based on the provision of assistance. Ideally, it would also prohibit forms of complicit influence that have a substantial effect on the principal's commission of the wrong. ${ }^{1209}$ The rule might be of particular relevance to state participation in violations of international humanitarian law by non-states groups. ${ }^{1210}$ Indeed, such a non-state analogue to Article 16 was recently cited by Austria in a brief arguing against the lifting of the arms embargo against Syria. ${ }^{1211}$ Although there is debate about the scope and theoretical underpinning of the obligations imposed by the law of armed conflict on non-state groups, ${ }^{1212}$ the existence of a core of

\footnotetext{
${ }^{1208}$ Cf Art 16 ARSIWA.

${ }^{1209}$ See Ch. 9.2.5.2 above.

${ }^{1210}$ See also Common Article 1 to the Geneva Conventions of 1949 (12 August 1949) 75 UNTS 31, 75 UNTS 85, 75 UNTS 135, 75 UNTS 287: 'The High Contracting Parties undertake to respect and to ensure respect for the present Convention in all circumstances.' (emphasis added); Nicaragua [220].

${ }^{1211}$ Syria: Austrian Position on Arms Embargo (as of 13 May 2013) available at $<$ http://www.ft.com/cms/1721c482-bcbc-11e2-b344-00144feab7de.pdf $>$ accessed 1 August 2013.

1212 See e.g. Antonio Cassese, 'The Status of Rebels under the 1977 Geneva Protocol on NonInternational Armed Conflict' (1981) 30 ICLQ 416; Sandesh Sivakumaran, 'Binding Armed Opposition Groups' (2006) 55 ICLQ 369.
} 
obligations is not controversial. ${ }^{1213}$ These are obligations with which each party to a non-international armed conflict must comply. ${ }^{1214}$

No doubt difficult questions would arise in respect of the requirement of knowledge and the nexus between the accomplice state's assistance and principal non-state actor's wrong. This is nothing new for complicity. Clause (b) ensures that the complicity rule is limited to instances where the state is prohibited from doing the principal act. As the ILC puts it in the Commentary on Article 16: 'a State cannot do by another what it cannot do by itself., 1215

A rule of this kind might become a useful restraint on the ways that states participate in wrongdoing committed by non-state actors. It would also resolve an irony in the development of the rule reflected in Article 16. By the time the International Law Commission's Articles on State Responsibility were adopted and started to ground themselves in the international legal system - fifty years after drafting commenced—-states had increasingly been joined by powerful non-state actors as potential violators of fundamental international norms. The rule reflected in Article 16 speaks only to the ways in which states participate in wrongdoing committed by other states. A non-state analogue would be a start towards remedying this gap.

\footnotetext{
${ }^{1213}$ See e.g. Common Article 3 to the Geneva Conventions of 1949. For an overview, see Cassese, International Law 429-434; Andrew Clapham, 'The Rights and Responsibilities of Non-State Actors: The Legal Landscape \& Issues Surrounding Engagement' (February 2010) Ownership of Norms Project - Towards a Better Protection of Civilians in Armed Conflict 6-21; Annyssa Bellal, Gilles Giacca, and Stuart Casey-Maslen, 'International Law and Armed Non-State Actors in Afghanistan' (2011) 93 Intl Rev. of the Red Cross 47.

${ }^{1214}$ Common Article 3 to the Geneva Conventions of 1949.

${ }^{1215}$ ARSIWA Commentary on Article 16 [6].
} 


\subsection{CONCLUSION}

The implications of such a non-state analogue to Article 16 should not be overstated.

Once complicity is adopted as the doctrinal tool through which to regulate the ways that states participate in harms caused by non-state actors, persisting limitations on non-state subjectivity in international law will continue to inhibit its operation. ${ }^{1216}$ For this reason, direct, non-derivative forms of state responsibility will continue to play a prominent role in constraining the ways that states interact with non-state actors. However, a general complicity rule, subsisting alongside specific prohibitions on state complicity, would graft onto any increases in the subjectivity of, and obligations borne by, non-state actors on the international plane. This could only contribute to compliance with international law.

${ }^{1216}$ Amoroso, 'Moving towards Complicity as a Criterion of Attribution' 994. 


\section{CHAPTER 10. CONCLUSION}

This thesis analysed how international law responds to individual and state complicity. Whenever complicity is prohibited, certain questions of scope and structure need to be resolved. To this end, this thesis proposed an analytical framework in which complicity rules may be assessed and defended a normative claim as to the optimal structure of complicity rules. The analytical framework structured the analysis around the forms of complicity prohibited, the nexus between the accomplice's act and principal's wrong, and the fault of the accomplice. The normative claim demands that actors are held responsible for, and labeled in terms of, their own contribution to the principal's wrong.

This analysis allows the following conclusions to be drawn. International criminal law prohibits individual complicity in the international crimes of other actors in a comprehensive way. The doctrines — instigation and aiding and abetting — are marked by the breadth of complicit conduct prohibited, encompassing both help and influence in Kadish's terminology, ${ }^{1217}$ a standard of knowledge in the fault element, and an underdeveloped nexus requirement. There is clearly doctrinal differentiation among participants in wrongdoing, but this doctrinal differentiation is not carried over into differentiation in the attribution of responsibility.

The comprehensive nature of complicity in international criminal law follows from the initial broad proscriptions of various forms of participation in crime. These broad proscriptions, which borrow from municipal criminal law, have allowed judges

\footnotetext{
${ }^{1217}$ Kadish, 'Complicity, Cause and Blame' 342.
} 
at international criminal tribunals to systematically develop complicity in international criminal law. This process may be contrasted with the way in which prohibitions on state complicity have arisen in international law.

In respect of state complicity in the internationally wrongful acts of other states, what we see is a move from specific complicity rules to a general rule. The prohibition of state complicity in aggression proscribes a specific form of complicity - the provision of territory — in a specific international wrong. The rule reflected in Article 16, although limited by the double obligation requirement, prohibits aid or assistance by the accomplice state that facilitates the commission of an internationally wrongful act by the recipient state. Crucially, the assisting state is responsible for its own contribution to the principal's wrong, rather than for the principal's wrong itself.

The rule in Article 16 represents a great leap forward for the regulation of complicity in international law. ${ }^{1218}$ The rule might be seen as a state analogue of international and municipal doctrines of criminal complicity. That comparison is not exact, for the rule in Article 16 excludes complicity by influence, thereby limiting the applicability of the rule in many instances that would fall within conventional definitions of complicity.

In respect of the ways that states participate in harms caused by non-state actors, there is a conceptual difficulty that the doctrine of complicity must overcome. Complicity is essentially derivative: it operates so as to link the accomplice to the

${ }^{1218}$ Lowe, 'Responsibility for the Conduct of Other States' 12. 
wrongdoing committed by the principal. ${ }^{1219}$ International law's historical normative structure, which imposed obligations only on states, foreclosed the possibility that a state's support for the acts of non-state actors could give rise to responsibility for complicity. ${ }^{1220}$ This presents a normative gap in the international legal system. ${ }^{1221}$

This thesis assessed two developments relating to state participation in the harms caused by non-state actors, both of which have a bearing on this normative gap. First, there is a claim that a new rule of attribution based on a complicit relationship, rather than an agency relationship, has arisen in the context of terrorist attacks. This claim is not the best interpretation of the legal materials and should be rejected on principled and policy grounds. Similarly, decisions of the institutions of the American Convention on Human Rights locate the attribution of conduct of non-state actors to the state in a relationship of complicity. As argued in Chapter 8 , there are sounds reasons to reject this approach.

The second development relating to state participation in the harms caused by non-state actors is more positive. As international law has come to impose obligations on non-state actors, so the possibility has arisen for articulating a state's responsibility in connection with the conduct of those actors in terms of complicity. International law now recognises wrongdoing on the part of the non-state actor to which the state may be linked. The prohibition on state complicity in genocide is the clearest example of a specific complicity rule of this kind. It is possible that a general rule will develop.

\footnotetext{
${ }^{1219}$ Kadish, 'Complicity, Cause and Blame' 337.

${ }^{1220}$ De Frouville, 'Attribution of Conduct' 276

${ }^{1221}$ Amoroso, 'Moving Towards Complicity as a Criterion of Attribution’ 992.
} 
International crimes are seldom committed alone. Plans are made, weapons provided, and encouragement rendered. When states go to war, third states allow their territory to be used; others provide military and financial aid. States fund rebel groups, harbour terrorists, and provide credit guarantees for companies engaged in human rights abuses abroad. As a factual relationship, complicity is commonplace. As a matter of law, the rule reflected in Article 16, subsisting specific complicity rules, emerging rules concerning state participation in harms caused by non-state actors, and the criminal law doctrines of instigation and aiding and abetting, demonstrate increasing attention to complicity in international law. Both our own wrongs, and the wrongs in which we are complicit, matter. 


\section{BIBLIOGRAPHY}

\section{Books}

Ashworth A, Principles of Criminal Law (6 ${ }^{\text {th }}$ ed., OUP 2009)

Aust H, Complicity and the Law of State Responsibility (CUP 2011)

Austin JL, How to Do Things with Words (OUP 1962)

Barnidge R, Non-State Actors and Terrorism: Applying the Law of State Responsibility and the Due Diligence Principle (TMC Asser 2008)

Becker T, Terrorism and the State (Hart 2006)

Boas G, Bischoff J and Reid N, Forms of Responsibility in International Criminal Law - International Criminal Law Practitioner Library Series: Volume I (CUP 2007)

Brownlie I, Principles of Public International Law ( $7^{\text {th }}$ ed., OUP 2008)

Carty H, An Analysis of the Economic Torts ( $2^{\text {nd }}$ ed., OUP 2010)

Cassese A, International Law ( $2^{\text {nd }}$ ed., OUP 2005)

Chinkin C, Third Parties in International Law (OUP 1993)

Crawford J, Brownlie's Principles of Public International Law (OUP 2012)

—State Responsibility: The General Part (CUP 2013)

Cryer R, Prosecuting International Crimes: Selectivity and the International Criminal Law Regime (CUP 2005)

Damgaard C, Individual Criminal Responsibility for Core International Crimes:

Selected Pertinent Issues (Spring 2008)

Dinstein Y, War, Aggression and Self-Defence ( $5^{\text {th }}$ ed., CUP 2012)

Duff A, Intention, Agency and Criminal Liability - Philosophy of Action and the Criminal Law (Blackwell 1990)

—Criminal Attempts (OUP 1996)

Fletcher G, Rethinking Criminal Law (first published 1978, OUP 2000)

Foster N \& Sule S, German Legal System and Laws (4th ed., OUP 2010)

Franck T, Recourse to Force - State Action against Threats and Armed Attacks (CUP 2002) 
Garner B (ed.), Black's Law Dictionary (9 ${ }^{\text {th }}$ ed., West 2009)

Gray C, International Law and the Use of Force ( $3^{\text {rd }}$ ed., OUP 2008)

Hart $\mathrm{H}$ and Honoré T, Causation and the Law ( $2^{\text {nd }}$ ed., Clarendon 1985)

Heller K, The Nuremberg Military Tribunals and the Origins of International Criminal Law (OUP 2011)

Higgins R, Problems and Process: International Law and How We Use It (Clarendon 1994)

Jennings R and Watts A, Oppenheim's International Law - Volume 1: Peace $\left(9^{\text {th }}\right.$ ed., Longman 1996)

Jørgensen N, The Responsibility of States for International Crimes (OUP 2000)

Lowe V, International Law (OUP 2011)

Meloni C, Command Responsibility in International Criminal Law (TMC Asser 2010)

Mettraux G, International Crimes and the Ad Hoc Tribunals (OUP 2005)

—The Law of Command Responsibility (OUP 2009)

Nagel T, Mortal Questions (CUP 1979)

Orakhelashvili A, Peremptory Norms in International Law (OUP 2006)

Quigley P, The Genocide Convention: An International Law Analysis (Ashgate 2006)

Peel E, Treitel's Law of Contract (13 ${ }^{\text {th }}$ ed., Sweet and Maxwell 2011)

Ruys T, 'Armed Attack' and Article 51 of the UN Charter: Evolutions in Customary Law and Practice (CUP 2010)

Saul B, Defining Terrorism in International Law (OUP 2006)

Schabas W, The UN International Criminal Tribunals - The Former Yugoslavia, Rwanda and Sierra Leone (CUP 2006)

-Genocide in International Law: the Crime of Crimes (2 ${ }^{\text {nd }}$ ed., CUP 2009)

- The International Criminal Court - A Commentary on the Rome Statute (OUP 2010)

Shue H, Basic Rights - Subsistence, Affluence, and U.S. Foreign Policy $\left(2^{\text {nd }}\right.$ ed., Princeton University Press 1996) 
Simester S et al, Simester and Sullivan's Criminal Law: Theory and Doctrine $4^{\text {th }}$ ed., Hart 2010) 253

Stevens R, Torts and Rights (OUP 2007)

Tomuschat $\mathrm{C}$ and Thouvenin J, The Fundamental Rules of the International Legal Order: Jus Cogens and Obligations Erga Omnes (Martinus Nijhoff 2006)

Trapp K, State Responsibility for International Terrorism (OUP 2009)

Van Sliedregt E, Individual Criminal Responsibility in International Law (OUP 2012)

Weiler J, Cassese A and Spinedi M (eds), International Crimes of State: A Critical Analysis of the ILC's Draft Article 19 on State Responsibility (Walter de Gruyter 1989)

Werle G, Principles of International Criminal Law (TMC Asser 2009)

White R and Ovey C, Jacobs, White, and Ovey - The European Convention on Human Rights $\left(5^{\text {th }}\right.$ ed., OUP 2010)

Williams G, Criminal Law - The General Part ( $2^{\text {nd }}$ ed., Stevens \& Sons 1961)

\section{Sections of Books}

Alexander L, 'Criminal Liability for Omissions: An Inventory of Issues' in Shute S and Simester A (eds), Criminal Law Theory: Doctrines of the General Part (OUP 2002) 121

Ambos K, 'Superior Responsibility' in Cassese A, Gaeta P and Jones J (eds), The Rome Statute of the International Criminal Court: A Commentary - Vol 1 (OUP 2002) 805

— 'Article 25 - Individual Criminal Responsibility' in Triffterer O (ed.) Commentary on the Rome Statute of the International Criminal Court: Observers' Notes, Article by Article $\left(2^{\text {nd }}\right.$ ed. Hart 2008) 743

Arnold R and Triffterer O, 'Article 28 - Responsibility of Commanders and Other Superiors' in Triffterer O (ed.) Commentary on the Rome Statute of the International Criminal Court: Observers' Notes, Article by Article (2 ${ }^{\text {nd }}$ ed., Hart 2008) 975

Ashworth A, 'Belief, Intent, and Criminal Liability' in Eekelaar J and Bell J (eds), Oxford Essays in Jurisprudence - Third Series (Clarendon 1987) 1

- 'Taking the Consequences' in Shute S, Gardner J and Horder J (eds), Action and Value in Criminal Law (Clarendon 1993) 107 
Bannelier K, 'Foundational Judgment or Constructive Myth? The Court's Decision as a Precursor to International Environmental Law' in Bannelier K, Christakis T and Heathcote S (eds), The ICJ and the Evolution of International Law: The Enduring Impact of the Corfu Channel Case (Routledge 2012) 242

Bianchi A, 'Enforcing International Law Norms against Terrorism: Achievements and Prospects' in Bianchi A (ed.), Enforcing International Law Norms against Terrorism (Hart 2004) 491

Corten $\mathrm{O}$ and Klein P, 'The Limits of Complicity as a Ground of Responsibility: Lessons Learned from the Corfu Channel Case' in Bannelier K, Christakis T and Heathcote S (eds), The ICJ and the Evolution of International Law: The Enduring Impact of the Corfu Channel Case (Routledge 2012) 315

Cryer R, 'General Principles of Liability in International Criminal Law' in McGoldrick D, Rowe P and Donnelly E (eds), The Permanent International Criminal Court: Legal and Policy Issues (Hart 2004)

David E, 'Article 34 - General Rule Regarding Third States' in Corten O and Klein $\mathrm{P}$ (eds), The Vienna Convention on the Law of Treaties: A Commentary - Volume 1 (OUP 2011) 887

De Frouville O, 'Attribution of Conduct to the State: Private Individuals' in Crawford J, Pellet A and Olleson S (eds), The Law of International Responsibility (OUP 2010) 257.

Dominicé C, 'Attribution of Conduct to Multiple States and the Implication of a State in the Act of Another State' in Crawford J, Pellet A and Olleson S (eds), The Law of International Responsibility (OUP 2010) 281

Dupuy P, 'State Sponsors of Terrorism: Issues of International Responsibility' in Bianchi A (ed.), Enforcing International Law Norms against Terrorism (Hart 2004) 3

Eser A, 'Individual Criminal Responsibility' in Cassese A, Gaeta P and Jones J (eds), The Rome Statute of the International Criminal Court: A Commentary - Vol 1 (OUP 2002) 767.

Glazebrook P, 'Structuring the Criminal Code: Functional Approaches to Complicity, Incomplete Offences, and General Defences' in Simester A and Smith A (eds), Harm and Culpability (Clarendon 1996) 195

Heathcote S, 'State Omissions and Due Diligence: Aspects of Fault, Damage and Contribution to Injury in the Law of State Responsibility' in Bannelier K, Christakis $\mathrm{T}$ and Heathcote $\mathrm{S}$ (eds), The ICJ and the Evolution of International Law: The Enduring Impact of the Corfu Channel Case (Routledge 2012) 295.

Hogan B, 'Omissions and the Duty Myth' in Smith P (ed.), Criminal Law: Essays in Honour of JC Smith (Butterworths 1987) 85 
Jørgensen N, 'State Responsibility and the 1948 Genocide Convention' in GoodwinGill G and Talmon S (eds), The Reality of International Law - Essays in Honour of Ian Brownlie (OUP 1999) 273

- 'The Obligation of Non-Assistance to the Responsible State' in Crawford J, Pellet A and Olleson S (eds), The Law of International Responsibility (OUP 2010) 687

- 'Complicity in Genocide and the Duality of Responsibility' in Swart B, Zahar A and Sluiter G (eds), The Legacy of the International Criminal Tribunal for the Former Yugoslavia (OUP 2011) 247.

Klein P, 'Attribution of Acts to International Organizations' in Crawford J, Pellet A and Olleson S (eds), The Law of International Responsibility (OUP 2010) 297

Ohlin J, 'Incitement and Conspiracy to Commit Genocide' in Gaeta $\mathrm{P}$ (ed.), The UN Genocide Convention: A Commentary (OUP 2009) 207

Pellet A, 'The ILC's Articles on State Responsibility for Internationally Wrongful Acts and Related Texts' in Crawford J, Pellet A and Olleson S (eds), The Law of International Responsibility (OUP 2010) 75.

Raz J, 'Promises and Obligations' in Hacker P and Raz J (eds), Law, Morality, and Society - Essays in Honour of H.L.A. Hart (Clarendon 1977) 210

Saland P, 'International Criminal Law Principles' in Lee R (ed.), The International Criminal Court: The Making of the Rome Statute - Issues, Negotiations, Results (Kluwer Law International 1999) 189

Salmon J, 'Article 26: Pacta Sunt Servanda' in Corten O and Klein P (eds), The Vienna Convention on the Law of Treaties: A Commentary - Volume 1 (OUP 2011) 659

Schmitt M, 'Responding to Transnational Terrorism under the Jus ad Bellum: A Normative Framework' in Schmitt M and Pejic J (eds), International Law and Armed Conflict: Exploring the Faultlines - Essays in Honour of Yoram Dinstein (Martinus Nijhoff 2007) 157

Suy E, 'Article 53 - Treaties Conflicting with a Peremptory Norm of General International Law ('jus cogens')' in Corten $\mathrm{O}$ and Klein $\mathrm{P}$ (eds), The Vienna Convention on the Law of Treaties: A Commentary - Volume II (OUP 2011) 1224

Talmon S, 'A Plurality of Responsible Actors - International Responsibility for Acts of the Coalition Provision Authority in Iraq' in Shiner P and Williams P (eds), The Iraq War and International Law (Hart 2008) 185

Werle G, 'General Principles of International Criminal Law' in Cassese A (ed.), Oxford Companion to International Criminal Justice (OUP 2009) 54 


\section{Journal Articles}

Ago R, ‘Le Délit International (1939) 68 (II) Recueil des Cours 419

Akhavan P, 'The Crime of Genocide in the ICTR Jurisprudence' (2005) 3 J. Intl Crim. Just. 989

Ambos K, 'Is the Development of a Common Substantive Criminal Law for Europe Possible? Some Preliminary Reflections' (2005) 12 Maastricht J. of Eur. \& Comp. L. 173

- 'Amicus Curiae Brief in the Matter of the Co-Prosecutors' Appeal of the Closing Order against Kaing Guek Eav “Duch” Dated 8 August 2008' (2009) 20 Crim. L. Forum 353

—'What Does “Intent to Destroy" in Genocide Mean?' (2009) 91 Intl Rev. of the Red Cross 833.

Amoroso D, 'Moving Towards Complicity as a Criterion of Attribution of Private Conducts: Imputation to States of Corporate Abuses in the US Case Law' (2011) 24 Leiden J. Intl L. 989

Ashworth A, 'The Scope of Criminal Liability for Omissions' (1989) 105 LQR 424

Bagshaw R, 'Can the Economic Torts be Unified' (1998) 18 OJLS 729

Bantekas I, 'On Stretching the Boundaries of Responsible Command' (2009) 7 J. Intl Crim. Just. 1197

Bellal A, Giacca G, and Casey-Maslen S, 'International Law and Armed Non-State Actors in Afghanistan' (2011) 93 Intl Rev. of the Red Cross 47

Berster L, "Duty to Act" and "Commission by Omission" in International Criminal Law’ (2010) 10 Intl Crim. L. Rev 619

Bethlehem D, 'Self-Defense against an Imminent or Actual Armed Attack by NonState Actors' (2012) 106 Am. J. Intl L. 770

Beynon H, ‘Causation, Omissions and Complicity’ (1987) Crim. L. Rev. 539

Bodansky D and Crook J, 'Symposium: The ILC's State Responsibility Articles Introduction and Overview' (2002) 96 Am. J. Intl L. 773

Bogdan A, 'Individual Criminal Responsibility in the Execution of a "Joint Criminal Enterprise" in the Jurisprudence of the ad hoc International Tribunal for the Former Yugoslavia' (2006) 5 Intl Crim. L. Rev. 63

Bowett D, 'Crimes of State and the 1996 Report of the International Law Commission on State Responsibility’ (1998) 9 Eur. J. Intl L. 163 
Brownlie I, 'International Law and the Activities of Armed Bands' (1958) 7 ICLQ 712

Byers M, 'Terrorism, the Use of Force and International Law after 11 September' (2002) 51 ICLQ 401

Caron D, 'The ILC Articles on State Responsibility: The Paradoxical Relationship between Form and Authority' (2002) 96 Am. J. Intl L. 857

Carty H, 'Joint Tortfeasance and Assistance Liability' (1999) 19 Legal Stud. 489

Cassese A, 'On the Use of Criminal Law Notions in Determining State Responsibility for Genocide' (2007) 5 J. Intl Crim. Just. 875

Cerone J, 'Human Dignity in the Line of Fire: The Application of International Human Rights Law During Armed Conflict, Occupation, and Peace Operations' (2006) 39 Vand. J. Intl L. 1447

Chalmers J and Leverick F, 'Fair Labelling in Criminal Law' (2008) 71 MLR 217

Clapham A, 'Human Rights Obligations of Non-State Actors in Conflict Situations' (2006) 88 Intl Rev. of the Red Cross 491

- Extending International Criminal Law beyond the Individual to Corporations and Armed Opposition Groups' (2008) 6 J. Intl Crim. Just. 899

— 'The Rights and Responsibilities of Non-State Actors: The Legal Landscape \& Issues Surrounding Engagement' (February 2010) Ownership of Norms Project Towards a Better Protection of Civilians in Armed Conflict.

Condorelli L, 'The Imputability to States of Acts of International Terrorism' (1989)

19 Isr. YB Human Rights 233

Crawford J, 'The ILC's Articles on Responsibility of States for Internationally Wrongful Acts: A Retrospect' (2002) 96 Am. J. Intl L. 874

Damaška M, 'The Shadow Side of Command Responsibility' (2001) 49 Am. J. of Comp. L. 455

Danforth J, 'Tortious Interference with Contract: A Reassertion of Society's Interest in Commercial Stability and Contractual Integrity' (1981) 81 Colum. L. Rev. 1491

Davies P, ‘Accessory Liability for Assisting Torts' (2011) 70 Camb. L. J. 353

Dawson G and Boynton R, 'Reconciling Complicity in Genocide and Aiding and Abetting Genocide in the Jurisprudence of the United Nations Ad Hoc Tribunals' (2008) 21 Harv. Human Rights J. 241

Dietrich J, 'Accessorial Liability in the Law of Torts' (2011) 31 Legal Stud. 231 
Dressler J, 'Reassessing the Theoretical Underpinnings of Accomplice Liability: New Solutions to an Old Problem (1985-1986) 37 Hastings L. J. 91

— 'Reforming Complicity Law: Trivial Assistance as a Lesser Offence' (2008) 5 Ohio State J. of Crim. L. 427

Dubber M, 'Criminalizing Complicity: A Comparative Analysis' (2007) 5 J. Intl Crim. Just. 977

Duff A, “"Can I Help You?” Accessorial Liability and the Intention to Assist' (1990) 10 Legal Stud. 165

Duttwiler M, 'Liability for Omission in International Criminal Law' (2006) 6 Intl Crim. L. Rev. 1

Eboe-Osuji, "Complicity in Genocide" versus "Aiding and Abetting Genocide": Construing the Difference in the ICTR and ICTY Statutes' (2005) 3 J. Intl Crim. Just. 56

Epstein R, 'Inducement of Breach of Contract as a Problem of Ostensible Ownership' (1987) 16 J. Legal Stud. 1

Eulau P, 'Inducing Breach of Contract: A Comparison of the Laws of the United States, France, The Federal Republic of Germany and Switzerland' (1978) 2 Boston College Intl \& Comp. L. Rev. 41

Fitzmaurice M, 'Third Parties and the Law of Treaties' (2002) 6 Max Planck YB of United Nations L. 37

Fletcher G, 'Complicity' (1996) 30 Isr. L. Rev. 140

Franck T, 'Who Killed Article 2(4)? Or: Changing Norms Governing the Use of Force by States' (1970) 64 Am. J. Intl L. 809

—_Terrorism and the Right of Self-Defence' (2001) 98 Am. J. Intl L. 839

Gaeta P, 'On What Conditions Can a State Be Held Responsible for Genocide' (2007) 18 Eur. J. Intl L. 631

Gardner J, ‘Complicity and Causality’ (2007) 1 Crim. L. \& Phil. 127

—_Moore on Complicity and Causality' (2008) U. Penn. L. Rev. Pennumbra 432

Giustiniani F, 'The Responsibility of Accomplices in the Case-Law of the Ad Hoc Tribunals' (2009) 20 Crim. L. Forum 417

Graefrath B, 'Complicity in the Law of International Responsibility' (1996) Rev. Belge de Droit Intl 371 
Greenawalt A, 'Rethinking Genocidal Intent: The Case for a Knowledge-Based Interpretation’ (1999) 99 Colum. L. Rev. 2259

Greenfield D, 'The Crime of Complicity in Genocide: How the International Criminal Tribunals for Rwanda and Yugoslavia Got It Wrong, and Why It Matters' (2008) 98 J. Crim. L. \& Criminology 921

Greenwood C, 'International Law and the United States' Air Operation against Libya' (1986/1987) 89 W. Va L. Rev. 933

Hakimi M, ‘State Bystander Responsibility’ (2010) Eur. J. Intl L. 341

Hohfeld W, 'Some Fundamental Legal Conceptions as Applied in Judicial Reasoning (1913-1914) 23 Yale L. J. 16

_ 'Fundamental Legal Conceptions as Applied in Judicial Reasoning' (1916-1917) 26 Yale L. J. 710

Holá B, Smeulers A and Bijleveld C, 'International Sentencing Facts and Figures Sentencing Practice at the ICTY and ICTR' (2011) 9 J. Intl Crim. Just. 411

Horder J, 'Rethinking Non-Fatal Offences against the Person' (1994) 14 OJLS 335

Howarth D, 'Against Lumley v Gye’ (2005) 68 MLR 195

Kadish S, 'Complicity, Cause and Blame’ (1985) 73 Calif. L. Rev. 323

- 'Act and Omission, Mens Rea, and Complicity: Approaches to Codification' (1989) 1 Crim. L. Forum 65

—'Reckless Complicity’ (1997) 87 J. Crim. L. \& Criminology 369

Kammerhofer J, 'The Armed Activities Case and Non-State Actors in Self-Defence Law' (2007) 20 Leiden J. Intl L. 89

Kirgis F, 'Israel's Intensified Military Campaign against Terrorism' Am. Soc. Intl L. Insight (December 2001)

Kutz C, ‘Causeless Complicity’ (2007) 1 Crim. L. \& Phil. 289

Lanovoy V, 'Responsibility for Complicity in an Internationally Wrongful Act: Revisiting a Structural Norm' (SHARES Conference - Foundations of Shared Responsibility in International Law, Amsterdam, 17, 18 November 2011) 1

Lauterpacht E, 'The Contemporary Practice of the United Kingdom in the Field of International Law - Survey and Comment' (1958) 7 ICLQ 514

Leavens A, 'A Causation Approach to Criminal Omissions' (1988) 76 Cal. L. Rev. 547. 
Lee P, 'Inducing Breach of Contract, Conversion and Contract as Property' (2009) 29 OJLS 511

Lillich R and Paxman J, 'State Responsibility for Injuries to Aliens Occasioned by Terrorist Activities' (1977) 26 Am. Univ. L. Rev. 217

Linderfalk U, 'The Effect of Jus Cogens Norms: Whoever Opened Pandora's Box, Did You Ever Think About the Consequences' (2007) 18 Eur. J. Intl. L. 853

- 'State Responsibility and the Primary-Secondary Rules Terminology - The Role of Language for an Understanding of the International Legal System (2009) 78 Nordic J. Intl L. 53

Lobel J, 'The Use of Force to Respond to Terrorist Attacks: The Bombing of Sudan and Afghanistan' (1999) 24 Yale J. Intl L. 537

Lowe V, 'Responsibility for the Conduct of Other States' (2002) 101 Japanese J. Intl L. 1

Martinez J, 'Understanding Mens Rea in Command Responsibility' (2007) 5 J. Intl Crim. Just. 638

— and Danner A, 'Guilty Associations: Joint Criminal Enterprise, Command Responsibility, and the Development of International Criminal Law' (2005) 93 Calif. L. Rev. 75

McChesney F, 'Tortious Interference with Contract versus "Efficient” Breach: Theory and Empirical Evidence' (1999) 28 J. of Legal Stud. 131

Meloni C, 'Command Responsibility: Mode of Liability for the Crimes of Subordinates or Separate Offence of the Superior?' (2007) 5 J. Intl Crim. Just. 619

Milanović M, 'State Responsibility for Genocide’ (2006) 17 Eur. J. Intl L. 553

— 'State Responsibility for Genocide: A Follow-Up' (2007) 18 Eur. J. Intl L. 669

Moore M, ‘The Metaphysics of Causal Intervention' (2000) 88 Cal. L. Rev. 827

— 'Causing, Aiding, and the Superfluity of Accomplice Liability' (2007) 156 U Penn LR 395

Murphy S, 'Contemporary Practice of the United States Relating to International Law’ (1999) 93 Am. J. Intl L. 161

- 'Contemporary Practice of the United States Relating to International Law - 2001' (2002) 96 Am. J. Intl L. 237

- 'Terrorism and the Concept of "Armed Attack" in Article 51 of the UN Charter' (2002) 43 Harv. J. Intl L. 41 
Nollkaemper A, 'Concurrence between Individual Responsibility and State Responsibility in International Law' (2003) 52 ICLQ 615

—'Internationally Wrongful Acts in Domestic Courts' (2007) 101 Am. J. Intl L. 760

— and Nedeski N, 'Responsibility of International Organizations "in Connection with Acts of States"' (2012) 9 Intl Org. L. Rev. 33

- and Jacobs D, 'Shared Responsibility in International Law: A Conceptual Framework’ (2013) 34 Michigan J. Intl L. 359

Nolte G and Aust H, 'Equivocal Helpers - Complicit States, Mixed Messages and International Law' (2009) 58 ICLQ 1

Noyes J and Smith B, 'State Responsibility and the Principle of Joint and Several Liability’ (1998) 13 Yale J. Intl L. 225

Ohlin J, 'Joint Intentions to Commit International Crimes' (2010-2011) 11 Chicago J. Intl L. 693

—van Sliedregt E and Weigend T, 'Assessing the Control Theory' (2013) 26 Leiden J. Intl L. 725

Osiel M, 'The Banality of Good: Aligning Incentives Against Mass Atrocities' (2005) 105 Colum. L. Rev. 1751.

Pellet A, 'Can a State Commit a Crime? Definitely, Yes!' (1999) 10 Eur. J. Intl L. 425.

Perlman H, 'Interference with Contract and Other Economic Expectancies: A Clash of Tort and Contract Doctrine' (1982) 49 Uni. Chicago L. Rev. 61

Pisillo-Mazzeschi P, 'Due Diligence and the International Responsibility of States' (1992) 35 German YB Intl L. 9

Quigley J, 'Complicity in International Law: A New Direction in the Law of State Responsibility’ (1986) 57 British YB Intl L. 77.

Ratner S, 'Jus ad Bellum and Jus in Bello after September 11' (2002) 96 Am. J. Intl L. 905

Raz J, 'Promises in Morality and Law' (1981-1982) 95 Harv. L. Rev. 916

Roberts K, 'The Law of Persecution Before the International Criminal Tribunal for the Former Yugoslavia' (2002) 15 Leiden J. Intl L. 623

Robinson D, 'How Command Responsibility Got So Complicated: A Culpability Contradiction, Its Obfuscation, and a Simple Solution' (2012) 13 Melb. J. Intl L. 1

Robinson P, ‘Imputed Criminal Liability’ (1984) 93 Yale L. J. 609 
— and John Darley, 'Objectivist v. Subjectivist Views of Criminality: A Study in the Role of Social Science in Criminal Law Theory' (1998) 18 OJLS 409

Rosand E, 'Security Council Resolution 1373, the Counter-Terrorism Committee and the Fight Against Terrorism' (2003) 97 Am. J. Intl L. 333

Ruys T, 'Quo Vadit Jus ad Bellum?: A Legal Analysis of Turkey's Military Operations against the PKK in Northern Iraq' (2008) 9 Melb. J. Intl L. 334

- and Verhoeven S, 'Attacks by Private Actors and the Right of Self-Defence' (2005) 10 J. Confl. \& Sec. L. 289

Sayre F, 'Inducing Breach of Contract' (1922-1923) 36 Harv. L. Rev. 663

Simester A, 'The Mental Element in Complicity' (2006) 122 LQR 578;

— and Chan W, 'Inducing Breach of Contract: One Tort or Two' (2004) 63 Camb. L. J. 132

Simma B, 'From Bilateralism to Community Interest in International Law' (1994) 250 Recueil des Cours 217

Smith J, 'Some Problems of the Reform of the Law of Offences against the Person' (1978) 31 Curr. Leg. Prob. 15

—Gillickv West Norfolk and Wisbech AHA [1986] Crim L.R. 113 (note)

Smith KJM, 'The Law Commission Consultation Paper on Complicity: Part 1: A Blueprint for Rationalism' (1994) Crim. L. Rev. 239

Stahn C, 'Terrorist Acts as "Armed Attack": The Right to Self-Defence, Article 51 (1/2) of the UN Charter, and International Terrorism' (2003) 27 Fletcher For. of World Aff. 35

Stewart J, 'The End of “Modes of Liability” for International Crimes' (2012) 25 Leiden J. Intl L. 165

Sullivan R, 'Conduct and Complicity: Liability based on Omission and Risk' (2008) 39 Cambrian L. Rev. 60

Talmon S, 'The Responsibility of Outside Powers for Acts of Secessionist Entities' (2009) 58 ICLQ 493

Tams C, 'All's Well that Ends Well - Comments on the ILC's Articles on State Responsibility’ (2002) Heidelberg J. Intl L. 759

- 'Do Serious Breaches Give Rise to Any Specific Obligations of the Responsible State' (2002) 13 Eur. J. Intl L. 1161 
Tange P, 'Netherlands State Practice for the Parliamentary Year 2000 - 2001' (2002) 33 Netherlands Y. Intl L. 191

Trapp K, 'Back to Basics: Necessity, Proportionality, and the Right of Self-Defence against Non-State Terrorist Actors' (2007) 56 ICLQ 141

— 'The Use of Force against Terrorists: A Reply to Christian J. Tams' (2009) 20 Eur. J. Intl L. 1049

van der Wilt H, 'Genocide, Complicity in Genocide and International v. Domestic Jurisdiction: Reflections on the van Anraat Case' (2006) 4 J. Intl Crim. Just. 239

Van Steenberghe R, 'Self-Defence in Response to Attacks by Non-state Actors in the Light of Recent State Practice: A Step Forward?’ (2010) 23 Leiden J. Intl L. 183

Vogel J, 'How to Determine Individual Criminal Responsibility in Systemic Contexts: Twelve Models' (2002) Cahiers de Défense Sociale 151

Waddams S, 'Johanna Wagner and the Rival Opera Houses' (2001) 117 LQR 431

Wasik M and Thompson M, "'Turning a Blind Eye” as Constituting Mens Rea' (1981) 32 NILQ 328, 330-331

Wedgwood R, 'Responding to Terrorism: The Strikes Against Bin Laden' (1999) 24 Yale J. Intl L. 559

Weinrib E, ‘A Step Forward in Factual Causation’ (1975) 38 MLR 518

Weisberg R, 'Reappraising Complicity’ (2000-2001) 4 Buff. Crim. L. Rev. 217

Werle G, 'Individual Criminal Responsibility in Article 25 ICC Statute' (2007) 5 J. Intl Crim. Just. 953

Williams G, 'Oblique Intention' (1987) 46 Camb. L. J. 417

Wilson W, 'A Rational Scheme of Liability for Participating in Crime' (2008) Crim. L. Rev. 3

Yeager D, 'Helping, Doing, and the Grammar of Complicity' (1996) 15 Crim. Just. Eth. 25

Zan M, 'Comment: John Howard's "Pre-emptive Strike Thesis"' (2003) 7 J. of South Pac. L. 4

\section{Blog Posts}

Cryer R, 'Command Responsibility at the ICC and ICTY: Two Minds on the Mental Element' (EJIL:Talk!, 20 July 2009) <http://www.ejiltalk.org/commandresponsibility-at-the-icc-and-icty-in-two-minds-on-the-mental-element/> 
Milanović M, 'Self-Defense and Non-State Actors: Indeterminacy and the Jus ad Bellum' (EJIL:Talk!, 21 February 2010) <http://www.ejiltalk.org/self-defense-andnon-state-actors-indeterminacy-and-the-jus-ad-bellum/ $>$

Nollkaemper A, 'The ECtHR Finds Macedonia Responsible in Connection with Torture by the CIA, but on What Basis?' (EJIL:Talk!, 24 December 2012)

$<$ http://www.ejiltalk.org/the-ecthr-finds-macedonia-responsible-in-connection-withtorture-by-the-cia-but-on-what-basis/>

- The Charles Taylor Judgment: Disconnecting the Responsibilities of Presidents and States' (SHARES Blog, 1 October 2013) < http://www.sharesproject.nl/thecharles-taylor-judgment-disconnecting-the-responsibilities-of-presidents-andstates/>

Ohlin J, 'Why did the ICTY Acquit Stanišić and Simatović?' (Lieber Code, 1 June 2013) <http://www.liebercode.org/2013/06/why-did-icty-acquit-stanisic-and.html>

Robinson D, 'Comment on Opinio Juris LJIL Symposium on James Stewart, The End of "Modes of Liability" for International Crimes - James Stewart Responds to Darryl Robinson' (Opinio Juris, 21 March 2012) <http://opiniojuris.org/2012/03/21/ljilstewart-responds-to-robinson/>

Stewart J, 'The ICTY Loses its Way on Complicity - Part 1' (Opinio Juris, 3 April 2013 ) <http://opiniojuris.org/2013/04/03/guest-post-the-icty-loses-its-way-oncomplicity-part-1/>

— 'The ICTY Loses its Way on Complicity - Part 2' (Opinio Juris, 3 April 2013) $<$ http://opiniojuris.org/2013/04/03/guest-post-the-icty-loses-its-way-on-complicitypart- $2 />$

— "Specific Direction" is Indefensible: A Response to Heller on Complicity' (Opinio Juris, 12 June 2013) <http://opiniojuris.org/2013/06/12/specific-direction-isindefensible-a-response-to-heller-on-complicity/>

—“"Specific Direction” is Unprecedented: Results from Two Empirical Studies' (EJIL:Talk!, 4 September 2013) <http://www.ejiltalk.org/specific-direction-isunprecedented-results-from-two-empirical-studies/>

\section{Newspaper and Magazine Articles}

Baer R, 'Finding Bin Laden Raises Questions About Pakistan's Complicity’ Time (New York, 2 May 2011)

Bilandzic B and Dervisbegovic N, 'Serbs Relieved, Bosnia Dismayed by Genocide Ruling' Reuters (Sarajevo, 26 February 2007)

Cassese A, 'A Judicial Massacre' The Guardian (London, 27 February 2007) 
'Court Clears Serbia of Genocide' BBC News (London, 26 February 2007)

Pflanz M, 'French Leaders Accused of Complicity in Rwanda Genocide' The Telegraph (London, 5 August 2008)

Reeves E, 'Arming Khartoum: China's Complicity in the Darfur Genocide' Sudan Tribune (Paris, 19 October 2010)

\section{England and Wales Law Commission}

Assisting and Encouraging Crime (Law Com Consultation Paper No 131, 1993)

Inchoate Liability for Assisting and Encouraging Crime (Law Com No 300, 2006)

Participating in Crime (Law Com No 305, 2007) 